\title{
Fragile Future: The Attack Against Public Services and Public Sector Unions In an Era of Austerity
}

\author{
Carlo Fanelli
}

A dissertation submitted to the Faculty of Graduate and Postdoctoral Affairs in partial fulfillment of the requirements for the degree of

Doctor of Philosophy

Department of Sociology and Anthropology

Carleton University

Ottawa, Ontario

(C) April 2013

Carlo Fanelli 
Library and Archives

Canada

Published Heritage

Branch

395 Wellington Street

Ottawa ON K1A ON4

Canada
Bibliothèque et

Archives Canada

Direction du

Patrimoine de l'édition

395 , rue Wellington

Ottawa ON K1A ON4

Canada
Your file Votre référence

ISBN: 978-0-494-94531-5

Our file Notre référence

ISBN: $978-0-494-94531-5$
NOTICE:

The author has granted a nonexclusive license allowing Library and Archives Canada to reproduce, publish, archive, preserve, conserve, communicate to the public by telecommunication or on the Internet, loan, distrbute and sell theses worldwide, for commercial or noncommercial purposes, in microform, paper, electronic and/or any other formats.

The author retains copyright ownership and moral rights in this thesis. Neither the thesis nor substantial extracts from it may be printed or otherwise reproduced without the author's permission.
AVIS:

L'auteur a accordé une licence non exclusive permettant à la Bibliothèque et Archives Canada de reproduire, publier, archiver, sauvegarder, conserver, transmettre au public par télécommunication ou par l'Internet, prêter, distribuer et vendre des thèses partout dans le monde, à des fins commerciales ou autres, sur support microforme, papier, électronique et/ou autres formats.

L'auteur conserve la propriété du droit d'auteur et des droits moraux qui protege cette thèse. $\mathrm{Ni}$ la thèse ni des extraits substantiels de celle-ci ne doivent être imprimés ou autrement reproduits sans son autorisation.
In compliance with the Canadian Privacy Act some supporting forms may have been removed from this thesis.

While these forms may be included in the document page count, their removal does not represent any loss of content from the thesis.
Conformément à la loi canadienne sur la protection de la vie privée, quelques formulaires secondaires ont été enlevés de cette thèse.

Bien que ces formulaires aient inclus dans la pagination, il n'y aura aucun contenu manquant. 


\begin{abstract}
This study is about the ongoing transformation of neoliberal public policy, precarious work, and public sector unions' struggles against demands for austerity. Situated in long-term historical perspective, I examine to what extent changes in the nature and content of government intervention, social welfare provision, and restructuring of the public sector are structurally-induced, the products of historical and contemporary circumstances, the result of mismanagement, or some combination of other factors. I argue that in addition to reducing the compass of social services, recent expenditure restraint measures have targeted unionized workers in order to lower wages and reduce benefits across the sector. Case studies include original analyses of striking workers at the Canadian Museum of Civilization Corporation, collective bargaining between teaching assistants and contract instructors and Carleton University, and striking civic workers at the city of Toronto. Together the cases break new ground in understanding how neoliberalism is being reconstructed and redeployed in light of the Great Recession and the consequences this has had on public sector workers and services.

The three jurisdictions in this study - municipal, provincial, and federal - represent three scales of neoliberal restructuring in Canada. While all three governments have resorted to some form of austerity, the methods used to reduce the deficit and move toward balanced budgets have been differential and multifaceted. These include service delivery restructuring, increasing use of public-private-partnerships, privatization, new user-fees, and/or consumption taxes, as well as public sector worker layoffs, workplace intensification, and the selling of Crown assets. I contend that such measures seek to shift the burden of recession onto the public sector by reducing social services provisioning and seeking concessions from unionized public sector workers. In fact, the state has taken a leading role in narrowing the field of free collective bargaining, suspending trade union rights, and implementing an aggressive program of dispossession.

Absent the collective capacities to stop let alone reverse these measures, public sector unions have reached an impasse. Unable to translate militancy into an alternative ideological perspective and a coherent political and economic program, they continue to desperately hang onto previous gains that look increasingly insecure and fragile. I argue that in order for unions to regain their once prominent role in the pursuit of social justice and workplace democracy, they will need to take the risks of organizing working class communities and fighting back while they still have some capacity to do so - else they risk continuing the decades-long labour impasse and union decline. In my view, this necessarily requires an explicitly anti-capitalist perspective, with the aim being to develop both alternative policies and an alternative politics rooted in the working class.
\end{abstract}




\section{Acknowledgements}

This thesis is dedicated to my parents, Carlo and Teresa Fanelli, whose courage, sacrifice and indefatigable effort to improve the quality of life for their children provided a stable bedrock of encouragement, love and support. Non avrei potuto farlo senza di vuoi. Thanks are due to my sister Stella, my brother Frank and his wife Poli. You have inspired and influenced me in numerous ways in the lead up and throughout this project. To my nephew Christopher and my nieces Adriana and Angelina: you are a constant joy in my life and a reminder of why I wrote this project. I would also like to thank Samantha Wilson for putting up with my constant complaints throughout the writing of this project and for always supporting and encouraging me to see it through to completion.

I would like to express my sincerest gratitude to my thesis supervisor Justin Paulson who encouraged me to pursue my varied intellectual curiosities as I struggled to narrow down my research project, challenged me to read further and think deeper, and was a constant beam of personal and scholastic support throughout my $\mathrm{PhD}$ studies. As a committee member, Sam Gindin always encouraged me to think ambitiously and outside the box. Sam's ability to translate complex ideas into clear and digestible material helped clarify and draw linkages between subject matter I would have otherwise likely been unable to unravel.

Both Justin and Sam have had to put up with less than polished drafts, panicked phone calls and extended emails. And yet, their responses were always encouraging, supportive and, most of all, enlightening, exceeding what any graduate student could have ever expected. Words cannot express my appreciation and gratitude. From our first meeting when I came to visit Carleton University as a place to pursue my PhD studies, Wallace Clement always shown an interest in my work, supported me intellectually and provided a steady hand navigating the often murky administrative waters. I genuinely hope the summation of my thesis is not the end, but the beginning of a long relationship with these three scholars committed to scholastic excellence and social justice.

I would also like to thank my internal examiner Rebecca Schein, as well as my external examiner Larry Savage. Their questions and concerns throughout my dissertation defense, while admittedly stumping me at times, was done in a collegial manner that challanged me to find alternative and complementary explanations, as well as opened my mind to new areas of research worthy of much thought. Far from the fire-breathing dragons that I presume many graduate students envision their examiners to be they were the epitome of collegial encouragement and support.

I would also like to very graciously thank Greg Albo who served as an unofficial fourth member of my committee for his unyielding support professionally and personally. Greg consistently encouraged me to read new material and put down my thoughts on paper. This project would not have been possible without Greg's sharp analytical and intellectual skills, keen editorial eye and willingness to read and comment on earlier drafts of this project. It is rare that one finds such a broad and truly encouraging network of colleagues and friends, and I am most grateful to have had the opportunity to work with such an intellectually stimulating and mutually respectful community of scholars. Thanks are also due to James Bzovey, Mark P. Thomas, George Rigakos and Bryan Evans for their positive reinforcement, assistance and consistent encouragement throughout the various phases of this project. I have also learned a great deal from my friends and fellow graduate students at Carleton University and elsewhere, as well as from my colleagues at the Socialist Project and the editorial board of Alternate Routes.

Finally, thanks are due to Marlene Brancato and Paula Whissell for their administrative know-how and support, the Department of Sociology and Anthropology, Faculty of Graduate and Postdoctoral Affairs, and Ontario Graduate Scholarship for their generous financial assistance and, last but certainly not least, all the trade unionists under review in this study for sharing their time, thoughts and energies with me. 


\section{Table of Contents}

Introduction.

I. Theoretical and Methodological Approach 1

II. Organization and Layout 6

Chapter 1. The Rise of Industrial Unionism and Public Sector Associations: 1850-1945 16

I. Pre-Industrial Canada and the Creation of a Working Class: 1850-1879

II. Capitalism Takes Hold: Private and Public Sector Unions' Early Struggles, 1880-1929

III. From Great Depression to Deficit-Spending: Public Services and Workers' Struggles for Union Recognition, 1930-1945

IV. Conclusion

Chapter 2. Canada's Keynesian Compromise and the Transformation of Public Sector Trade Unionism: From Expansion to Impasse, 1946-1983

I. Keynes' 'Progressive' Liberalism 53

II. Canada's Keynesian Compromise: 1946-1962 58

III. From Expansion to Impasse: 1963-1983 69

IV. Conclusion 85

Chapter 3. Neoliberalism and the Assault on Public Sector Services and Unions: 1984-2005

I. Neoliberalism and New Spaces of Accumulation 89

II. Remaking Labour Market Policy 94

III. Neoliberalism Moves Centre Stage: 1984-1994 98

IV. The Continuing Assault Against Public Services and Unions: 1995-2005 107

V. Consolidating Neoliberalism 116

VI. Conclusion 120

Chapter 4. Neoliberal Federalism: Ottawa-Gatineau Museum Workers and the Struggle Against Precarious Employment, 2006-2011 123

I. The Great Recession and Public Sector Retrenchment 124

II. Museum Workers On Strike 131

III. From Minority to Majority Government 140

IV. Conclusion 145 
Chapter 5. Ontario and the Public Sector Squeeze: CUPE 4600 and Collective Bargaining at Carleton University, 2006-2011

I. Ontario Responds to the Great Recession:

The Open Ontario Plan

II. PSE Reform and Marketization: At the Crossroads of Student and Worker 164

III. CUPE 4600 and Collective Bargaining at Carleton University 169

IV. Neoliberal Redux: Consolidating Austerity 179

V. Conclusion

Chapter 6. Municipal Malaise: Neoliberal Urbanism and the Attack Against Public Services and Workers in Toronto, 2006-2011 184

I. Urban Neoliberalism and Public Restructuring in Toronto 185

II. 'Third Way' Urbanism 190

III. Collective Bargaining at City Hall 196

IV. From Miller Time to Ford Nation: Austerity Intensified 204

V. Conclusion 214

Chapter 7. Renewing Working Class Politics: Labour and the Struggle for Public Services

I. Marx and Engels on the Progressive Potential and Political Limitations of Trade Unionism 219

II. Shifting Demographics and the Feminization of Organized Labour $\quad 227$

III Private Prosperity: Who Profits? 238

IV. Public Austerity: Who Pays? 243

V. There Is Always An Alternative: Making the Case
for an Expanded Public Sector

VI. Conclusion 254

$\begin{array}{ll}\text { Conclusion. } & 256\end{array}$

I. Summary 258

II. Limitations and Future Research 267

$\begin{array}{ll}\text { Reference List. } & 273\end{array}$ 


\section{Introduction}

What began as an unprecedented housing meltdown centered in the U.S. economy in the Fall of 2007, quickly turned into a global insolvency crisis through 2008 and later the most significant recession since the Great Depression of the 1930s. In order to counter a sharp downturn, state treasuries the world over responded with public stimulus, new subsidies, spending initiatives and public sector restructuring in order to enhance competitiveness and accelerate economic expansion (Albo et al., 2010; Callinicos, 2010; Foster and Magdoff, 2009). Given the international context, my dissertation examines how pressures related to a deteriorating economic climate have intensified efforts to restructure relations between the state, capital and labour in Canada. In particular, this study is about the ongoing evolution of neoliberal public policy, precarious work and public sector unions' struggles against demands for austerity. Situated in long-term historical perspective, I utilize an integrated, multiscalar analysis in order to chart the public policy and administrative responses of the Governments of Canada, Ontario and Toronto. Because struggles over state restructuring and dispossession occur on a variety of scales - some local, some regional, others national and international - case studies from the governments of the national state, largest province and largest city are particularly illustrative of flashpoints of reform and labour confrontation.

\section{Theoretical and Methodological Approach}

Grounded in a policy sociology and critical political economy perspective, I examine how changing fiscal conditions have impacted the distribution and efficacy of public services and public finances, and the consequent impacts that such changes have had on public sector employees and the users of public services. I utilize qualitative methodologies and secondary quantitative data. I ground my analysis in three case studies showing how the economic and political climate affected collective bargaining with unions at the federal, provincial and municipal spheres. In employing an 
intersectional and holistic method of analysis (Clement, 2007), I examine to what extent such changes in the nature and content of government intervention, social welfare provision and restructuring of the public sector are structurally-induced, the product of historical and contemporary circumstances, the result of mismanagement or some combination of other factors. My analysis is informed by engaged research and a first person scholarly account of how collective bargaining has been influenced in light of the recession and new pressures for austerity. I argue that in addition to reducing the compass of social services, expenditure restraint measures have targeted unionized workers with the aim being to lower wages and reduce benefits. While each case study has its own specificity, together the cases provide fruitful terrain for developing an understanding of how long-term neoliberal policies are intensified in moments of crisis.

The three case studies are linked by analysis throughout and detail how public services and public sector workers have come under attack in light of capitalist and state militancy. It is important to stress, however, that public sector unions - like their private sector counterparts - are not organized in a homogenous fashion. Each association and union encountered their own unique set of historical challenges and constraints along the path toward unionization. Also, there are wideranging forms of public sector work from hospital workers to teachers, prison guards, police services, health and science researchers. While this specificity is important and cannot be overlooked, this study aims to generalize historical challenges to contemporary concerns. While each of the unions and workers involved in the strikes under consideration have had very different historical trajectories, relationships with the state and political cultures, collectively they illustrate the variety of forms of employment and resistance by public sector unions in an unprecedented and indefinite period of austerity. Therefore my case studies are unique in that they analyze three different political parties (or governing coalitions) at three scales of governance, and three distinct union Locals of varying sizes and histories, each representative of diverse forms of public sector 
work. These jurisdictions are at the centre of neoliberal restructuring in Canada. Thus not only do they reveal broader trends in public sector labour relations, they also illustrate the forms of resistance and strengths/limitations of existing union capacities.

In this study, I utilize three overlapping forms of participant investigation: (1) participant observation from the perspective of a student and activist; (2) as a teaching instructor, student and union member; (3) and as a long-time civic employee, union member and picket captain in the midst of a strike. Given my unique location in each of the cases my analyses are demonstrative of intellectual work on the front lines. That is to say, they aim to overcome the distance of intellectual work by supplementing textual evidence, union documents and media reports with a first person account of the interstices of the struggles. One of the advantages of being a participant observer is that I am able to gain access to a group of workers who would otherwise perhaps not consent to being studied and analyzed. This has the added benefit of avoiding the observer effect, potential changes in individuals' behaviour if they know they are being studied.

As such, participants and trade unionists generally behaved as they ordinarily would, which meant that my research was open to new insights as the research questions were not fixed in advance. This allowed me to carefully detail the social interactions and methods used by workers as they struggled to understand and respond to demands for concessions. In utilizing such a method of research I am able to collect and interpret data, which would otherwise be unavailable or missed using other methods. Of course, I also draw on existing scholarly works, Statistics Canada reports, newspapers, magazines, business and labour studies, formal and informal interviews, think-tank discussion papers, bank and bond rating agencies, non-governmental organizations, as well as government documents and reports in order to supplement the qualitative date I have collected. 
There has been surprisingly little research examining how the Great Recession has differed in Canada versus other countries, across the provinces or municipally. Even fewer studies have detailed the particular tribulations of small, medium and large union Locals as they struggled to resist demands for concessions. Of what research has been conducted they often present conflicting analytical conclusions. Generally, some attribute state indebtedness to overgenerous social entitlements and abuse from its users, public sector union monopoly, inefficient delivery models and/or government mismanagement (Mallet and Wong, 2008; Lauren and Robson, 2011; KPMG, 2009; Tufts and Fairbanks, 2011). Others take issue with regressive changes to taxation policy, growing concerns over corporate and financial power, declining revenue streams, precarious work and market competition (Sanger, 2011; Loxley, 2010; Albo and Evans, 2010; McCarthy et al, 2010). Some studies have also tended to focus on narrowly economistic measures (e.g. debt-to-GDP ratios, job losses) or overtly political concerns (e.g. the party in power, trade union political practices), with secondary attention given to broader sociological matters such as the gendering and racializing of the labour process, class and workplace restructuring of the public sector. While these positions have their merits, a common analytical shortcoming has been to isolate each process independent of the social configurations in which they are embedded. Thus, my study aims to address these previous shortcomings by integrating theoretical paradigms and research methodologies in the hopes of generating new sociological insights. As an employee and union member in two out of the three case studies under review, my dissertation aims to overcome some of the distance of intellectual work. Furthermore, by investigating and understanding how long-term public sector union practices and state policies have coalesced with contemporary socio-economic and political conditions, I aim to contribute to informed public policy debates.

Across the case studies, the extent of state coercion varies as do the responses by unions. While all three governments have resorted to some form of austerity, the methods used to reduce the 
deficit and move toward balanced budgets has been differential and multifaceted often combining various measures. These reconfigurations have often included some form of service delivery restructuring, increasing use of public-private-partnerships, privatization, new user-fees, consumption taxes and/or planned tax cuts, as well as public sector worker layoffs, workplace intensification and/or the selling of Crown assets. I contend that such measures seek to shift the burden of recession onto the public sector by reducing social services provisioning and seeking concessions from unionized public sector workers. This restructuring has reproduced and intensified patterns of classed, racialized and gendered labour market segmentation and inequality by ignoring socio-historical structural relations and transformations in the breadth and depth of protective labour regulations. Regardless of the political party or coalition in power, the case studies show how each one of them in government has sought to further discipline workers to the imperatives of capital amidst a hardening of neoliberalism. With ever-more authoritarianism and coercion, the state has come to lead in narrowing the field of free collective bargaining, suspending trade union rights and implementing an aggressive program of dispossession. Absent the collective capacities to stop let alone reverse these measures, public sector unions have reached an impasse: unable to translate militancy into an alternative ideological perspective and political and economic program, they continue to desperately hang onto previous gains that look increasingly insecure and fragile. This raises important concerns about the structural limitations which unions alone are powerless to overcome. Therefore, I argue, should unions strive to regain their once prominent role in the pursuit of social justice and workplace democracy they need to take the risks of organizing working class communities and fighting back while they still have some capacity to do so or risk continuing along the several decade long union impasse and general decline in living standards. In my view, this necessarily requires an explicitly anti-capitalist ideological and political economic perspective, with 
the aim being to develop both alternative policies and an alternative politics rooted in the working class.

\section{Organization and Layout}

Chapter one begins with an examination of Canada's distinctive transition to a capitalist economy. This is necessary in order to draw attention to the ways in which an earlier era of class struggles challenged the rule of capital and state hostility to trade unions' right to organize and bargain collectively. As scientific management and Fordism routinized and disciplined workers, the responses of most public sector associations differed sharply from their private sector counterparts. While the former eschewed notions of class struggle and direct confrontations, the latter developed militant forms of working class self-activity that struggled to secure the right to organize and bargain collectively. Part of this is explained by the fact that most public sector associations were initially assembled as social clubs or benefit societies, as opposed to explicitly worker organizations. With the onset of WWI, Great Depression and WWII, major breakthroughs for private sector workers cemented industrial unionism. For public sector unions and associations, however, many remained largely conservative, stunting both the development of public sector trade unionism and progressive labour legislation.

Chapter two begins with a examination of John Maynard Keynes' central theoretical propositions. This is necessary in order to understand the historical specificity of the Keynesian welfare state and later neoliberalism. I argue that while Keynes' ideas were progressive in comparison with his classical liberal counterparts, they nevertheless remained conservative at the core seeking to stabilize the capitalist system rather than alter it in any fundamental ways. Moving forward, I explore how the Keynesian welfare state - despite its limitations - entrenched notions of shared collective responsibility and redistributive justice. But as tailwinds of recession appeared in the 1970 s, Canada became a pathbreaker in deconstructing the welfare state and implementing 
neoliberal reforms. Indeed, one of the chief distinguishing features of neoliberalism in Canada is the extent to which state and capitalist class militancy actually led the charge against workers, working class standards of living and trade unions.

While recognizing the legal significance of public sector association, through this time public sector unions also came to recognize the political importance of trade union struggles. This coincided with the beginnings of a shift in the centre of gravity in the Canadian labour movement from one centred in private sector trade union militancy to one increasingly centred in the public sector and female-led. While this transition was slow and gradual, it coincided with sustained assaults against trade unions rights to organize and bargain collectively. This included legislation preventing workers from going on strike, increasing use of back-to-work legislation and efforts to undercut the growing power of labour. Despite the extension of formal collective bargaining rights, I argue that consecutive amendments to the formal procedures governing the legitimate realm of trade union activities narrowed the scope of permissible militancy and entrenched a system of highly legalistic provisions which served to depoliticize the broader labour movement and working class politics as a whole. Moreover, just as many public sector workers were extended the right to strike and bargain collectively, broader macro-economic and political changes further constrained the scope of agency and bargaining.

Chapter three begins with a theoretical analysis of the neoliberal counter-revolution. This is necessary in order to grasp how concrete material conditions owing to the contradictions of capitalism coincided with an intellectual onslaught against what vestiges of Keynesianism remained. I demonstrate how neoliberal policy prescriptions rose to prominence through the 1980s, slowly displacing the welfare state and establishing itself as the orthodox political program. In authoritatively undermining public sector unions and imposing public sector austerity, I argue that 
neoliberal objectives remolded labour market policies along increasingly individualized, competitive and precarious forms of work.

Next, I overview major public policy and legislative changes and detail the manner in which public sector unions were expected to bare the burden of economic crisis owing to recession. I contend that as neoliberal-inspired reforms gained prominence in policy making circles, unions and public services increasingly came under attack as wasteful and unaffordable. From Mulroney to Chretien and Peterson to Harris, this resulted in a much more confrontational collective bargaining climate as unions resisted concessions and sought to politicize the restructuring of the public sector as a whole. Both the 1995 federal Liberal and Ontario Conservative budgets represent the opening salvos in an intensified period of capitalist and state militancy in seeking to undermine unionism and drastically open-up public services to private sector provisioning. In response, public sector unions increasingly challenged the legal constraints of unionism as they came to understand collective bargaining as an essentially important political process. With the decoupling of the postwar class compromise, however, labour increasingly appeared defeated unable to counteract the combined efforts of capitalist and state restructuring.

Examining the period 2006 to 2011, Chapter four is the first of three subsequent chapters investigating how public services and unions have come under attack in light of the Great Recession. In this chapter, I contend that Stephen Harper's Conservatives have not only consolidated the earlier set of reforms implemented by the Liberals, but that the severity and specificity of the recession has served as a functional rationale for further embedding marketreinforcing policies. After discussing some of the broader public policy reforms which seek to reduce the public sector's role in the economy and, by extension, extend the space for capital accumulation, I examine how the broader political-economic climate of austerity impacted collective bargaining between the Canadian Museum of Civilization Corporation, a federal Crown 
corporation, and PSAC Local 70396 workers. My analysis is distinct in that it draws on participant observation from the perspective of a student and activist. Throughout the strike I took part in picket line demonstrations, attended meetings, engaged union members in formal and informal conversations, interacted with the public through picket line demonstrations and participated in strike support solidarity initiatives. While striking PSAC workers in Local 70396 were certainly not, on the whole, anti-capitalist in their aims and efforts, their forms of protest and public engagement went a long way in connecting with the broader community and making the linkages between public services, workers and those who rely on those services.

However, while workers learned and struggled collectively - demonstrating the importance of fighting back - the strike also revealed some of the structural limitations of trade unionism as an end in itself as future demands for concessions loom large. Although a relatively small local, striking PSAC workers' resistance to demands for concessions provides an important example of public sector workplace resistance. Additionally, I show how the Harper Conservatives' program of austerity and attacks against unions has intensified in light of their gaining of a majority as is demonstrated by the coercive use of back-to-work legislation in the cases of the Canadian Union of Postal Workers and Canadian Auto Workers. Through and through, the Conservatives continue to restructure the relationship between the state, capital and labour, opening-up new spaces for commodification, extending forms of corporate welfare and continuing efforts to squeeze more "productivity" out of public sector workers.

In chapter five I argue that the Ontario provincial Liberals have consolidated and extended the neoliberal project set in motion by the Rae New Democrats and Harris Conservatives. Rather than depart from the market-led revamping of the public sector, the McGuinty Liberals have quietly and sometimes through more dramatic ruptures embedded neoliberal policies into the overall architecture of public policy. As the Great Recession made itself felt on Ontario, the Liberal 
government of Dalton McGuinty responded in a thoroughly neoliberal manner calling for a decade of austerity. This included forms of tax relief for corporations, a wage freeze for public sector workers, less than genuine negotiations with public sector unions, efforts to privatize public assets, promoting hyper-competitive trade liberalization, and regressive reforms to employment standards legislation. These claims are concretized through an analysis of the Open Ontario Plan and in the Liberals' implicit stifling of free collective bargaining. This is demonstrated by the Carleton University administration's claim that their hands were tied by provincial measures in negotiations with CUPE Local 4600 . Because the Liberals maintained that they would not be funding any net compensation increases related to collective bargaining costs at Ontario Universities, the Carleton University administration sought to use this as an excuse to implement a wage freeze and a host of surveillance, speed-up and disciplinary measures. My analysis is based on my experiences as a graduate student and teaching assistant at Carleton University. It is also informed by my experiences as a CUPE 4600 member and provides a unique scholarly analysis of trade union organizing based on participant observation from the perspective of a student, activist and worker. I argue that the economic crisis served as a political pretext undermining free collective bargaining as the Liberal government, via Carleton University, sought to increase the scope of precarious work as a means of deceptive cost-savings. Although Carleton University teaching assistants and contract instructors did not go on strike, the issues and concerns in the lead up and during negotiations provide useful insights into the state of collective bargaining during an era of austerity.

The implicit aim of such plans is to shift the burden of recession onto the public sector while turning public spaces into profitable outlets for capital accumulation. While the first four years of the Liberals' mandate was characterized by relative labour peace, this was not due to a new consensual and collaborative relationship between public sector unions and the government but the result of the historically specific macro-economic and political circumstances predating the Great 
Recession. The relative labour peace also signified the political realignment of labour, embodied in the shift to the Liberals, expressing trade unions' adaptations to the authoritarian conditions of neoliberalism. The experiences of CUPE 4600 and its relationship with other unions on campus in the lead up to negotiations illustrate some of the institutional and legal constraints of unionism. The inability to foster active solidarity thus implies that few if any forms of unionism alone are capable of resisting state austerity and the capitalist class' aggressive push for commodification without an oppositional political anchor and organizational form in which to orient working class struggles.

Chapter six explores how the Great Recession has led to new rounds of attacks against civic workers amidst increasing pressures to privatize city services. I argue that through the 2009 round of bargaining between the City of Toronto and its civic workers, the City sought to shift the burden of recession onto workers by positing a false trade-off between wage restraint and the protection of public services. Given the location of Toronto as the strategic centre of financial capital in Canada and home to Canada's largest municipal union, Local 79, the 2009 round of bargaining vividly demonstrates the state's quest on behalf of capital to commodify new spaces for accumulation. Rather than retreat from the neoliberal project or present an alternative developmental path in the face of declining revenues, the 'Third Way progressivism' of the Miller regime sought to extract concessions from workers using the rationale that the recession demanded austerity.

My analysis is informed by my experiences as a part-time worker with the city of Toronto for more than a decade and as a picket captain through the 2009 strike. In the lead up to bargaining and during the strike, the Local 79 executive and, by extension, its members demonstrated an alarmingly ill-equipped response to the City's demands for concessions along with limited community support and solidarity. While some of these weaknesses stem from organizational failings, this problematic is related to broader concerns concerning the lack of active solidarity between the union executive and its rank and file members. In short, the union failed to come to 
terms with the limits of militancy alone which, in the absence of an oppositional political program, was incapable of countering the drumbeats of austerity and neoliberalism.

As a result, in the subsequent mayoral election these shortcomings contributed to the election of a conservative mayor and council intent on radically restructuring the city along increasingly competitive pressures, with efforts to lower the wage and compensation benefits of its public sector workforce and privatize city services and assets. In light of CUPE Local 79's significant political failures, the implication is that if unions are to reappear as a movement and not simply hang on as a relic of the past, they need to move beyond the limited defense of their own members' interests and to those of the working class as a whole. Doing so requires having feet both inside and outside the trade union movement, that is, rooted in an organizational form explicitly intent on building a broader working class movement across the many cleavages among workers and infused with a deep and critical analysis of (neoliberal) capitalism.

Chapter seven explores precisely this. I begin with an exploration of the work of Marx and Engels in order to shed light on the progressive potential and political limitations of trade union organizing as an end in itself. Although trade unions emerged from the working class, they did not come to represent the interests of the class as a whole. Thus, while organizing workers at the point of production is not only important but necessary, failing to come to terms with the root sectionalism of trade unionism organized labour risks impeding the formation of an alternative class project. I argue that despite the importance and significance of trade union struggles no form of unionism alone can challenge the neoliberal program of austerity and retrenchment or the consolidated power of capital and the state.

With this in mind, I examine the shifting demographics of the Canadian labour movement. I argue that over the period of neoliberalism, the centre of gravity of Canadian labour has increasingly shifted into the public sector and become feminized. This has reversed the long- 
standing pattern of militancy dominant in the private sector as public sector unions are increasingly at the forefront of workplace upheavals. But while strikes and other forms of labour protest are important, they rarely translate into a political and class-conscious movement beyond the immediate event. Paradoxically, despite a significant economic downturn that should have put labour and activists on the offensive, many are more atomized and alienated than ever.

This is evident through an analysis of who pays and who profits during times of economic crisis. Contrary to the claim that lower taxes on corporations and high-income earners generate enhanced private sector investments and higher public revenues, I show how over the period of neoliberalism quite the contrary took place. Lower corporate and high-income earning taxes have not only resulted in reduced investments in new machinery and new hiring, but has contributed to class disparities in wealth and income unmatched since the 1930s. The consequences have been to increase precarity of employment, breakdown collective responses, weaken trade union efficacy and increase individual insecurity. In fact, one of the chief distinguishing features of public sector workers and unions more generally is that their wages and benefits, often although not always, are contingent upon private sector profits which in turn are transferred to the state via a number of tax and transfer systems. Because many public services are funded through general tax revenue as well as personal and corporate taxes, in times of economic uncertainty and decreased growth pressures for public services and workers to reduce wages and benefits are intensified. This is a structural constraint which public sector workers are unable to overcome absent the recognition and subsequent removal of a dependence on private sector capital accumulation.

Rather than continue down the path of neoliberal capitalism, I argue that a new historical project must be placed on the agenda, one which removes the public sector's (and private sector's) reliance on capital valorization. While enhanced "regulations" are important and necessary for any class-oriented political-economic strategy aiming for a more equitable and just society, absent the 
fundamental reorientation of the public sector as a whole these initiatives will remain incompatible with the logic of capital and, therefore, temporary and conjunctural at best. Often, calls for "reregulation" implicitly assume that the state and market stand in opposition to each other. But as the state interventions and practices discussed in chapters four through six make clear, state policies have reinforced market mechanisms and increased precarity rather than challenged the rule of capital in any way. Furthermore, part of the problem with calls for state "controls" and "regulations" on capital is that they fail to identify the problem as structural and systemic - that is to say, endemic to capitalism and the ways in which capital and the state have extended and reproduced neoliberalism.

Rather, what is needed in my view is to fundamentally transform the whole banking sector into a public utility so that the distribution of credit and capital could be undertaken with democratically established principles. In addition to tightening regulations on capital, then, I make the case that nationalizing parts of the banking sector could remove the institutional and financial infrastructure of capital, thereby enhancing democratic control and potentially serving as an example for other sectors of the economy. Instead of continuing to rely on the private sector as the engine of economic growth and investment, an alternative framework must come to advance a vision of democratic social planning within an expanded public sector. This could potentially remove the public sector's dependence on private sector profits and replace the production and distribution of services from one subject to market pressures to one based on social needs. Therefore, in my view, only a class-oriented trade union movement espousing a working class politics that seeks to transcend the capitalist system may offer a way out of the crisis that is capitalism. All things considered, the future of public services and collective bargaining rights in an era of austerity seem fragile and insecure. The shape taken by struggles over austerity and social services, then, may well determine whether neoliberalism continues uninterrupted or alternatively 
whether a new historical project might be placed on the agenda. This study seeks to contribute to the latter. 


\section{Chapter 1 - The Rise of Industrial Unionism and Public Sector Associations: 1850-1945}

\footnotetext{
"History is emphatically not 'past politics'; it is the life of yesterday in the present."
}

(Mackintosh,1923, p.12)

I begin this chapter with an examination of Canada's unique transition to a capitalist economy. It is necessary to undertake such an historical overview as the shapes taken by struggles influence understandings of the present era and the remedies offered for existing concerns. In order to flesh out the distinction between pre-capitalist social formations and the historically specific imperatives of capitalist production, I discuss the transformation of agrarian populations and the creation of a working class. I contend that as capitalist social imperatives increasingly became dominant through the early twentieth century, "scientific management" and Fordism worked to routinize and discipline workers. In an effort to resist the imperatives of capital, workers increasingly sought to organize themselves into trade unions. As will be shown, however, the experiences of public and private sector unions differed greatly. While the former often engaged in direct political confrontations, public sector associations eschewed notions of class struggle relying on close networks of patronage.

I make the case that although a good many private sector unions were struggling to secure the right to organize and bargain collectively, several public sector associations disassociated themselves from trade union struggles and working class politics. With the onset of the First World War, Great Depression and later World War Two, struggles by trade unionists led to important advancements which eventually cemented industrial unionism. This also contributed to the consecutive development of basic social services provisions and a growing recognition of collective social responsibility. However, public sector workers did not experience a similar series of breakthroughs. Instead, many associations continued to rely on patronage and individual appeals to management in order to improve wages and working conditions. As a consequence, I argue that the 
pre-WWII history of public sector unions, notwithstanding important exceptions, was generally conservative. Why was this so? And how did these contrasting experiences influence the development of progressive labour legislation for private and public sector workers?

\section{Pre-Industrial Canada and the Creation of a Working Class: 1850-1879}

The rise of industrial unionism and public sector associations are intimately connected to the pre- and early industrialization of Canada. The shape taken by struggles over resistance to the encroachments of capital, including the consolidation of the Canadian nation, played a significant role in establishing the legal, political and economic parameters through which unions would later struggle. Scholars remain divided over the specific social configurations, economic and political causes, as well as technological and geographical factors which gave rise to capitalism in Canada. ${ }^{1}$ Nevertheless, general distinctions can be drawn between Canada's pre-industrial agrarian phase and subsequent capitalist development. Of course, initial settlements in the different regions of what is now Canada were far from uniform, exhibiting a large degree of heterogeneity in the formation of state institutions, degree of market penetration and the development of a landless proletarian. Having forcefully dispossessed and segregated Aboriginal peoples, Canada was developed around the exploitation of its natural resources and export of fish, fur, timber grain and other staples (Innis, 1956; Mackintosh, 1923; Watkins and Forster, 1963). Prior to the 1850s, there were few signs of industry as the nation remained largely untouched by international trade. The majority of the population remained engaged in agrarian pursuits, while production and consumption largely took place in the household. The family farm was the major purveyor of the means of life and the rural

\footnotetext{
${ }^{1}$ The Canadian debate is, of course, embedded within broader debates about the transition to capitalism (Wood, 2002; Perelman, 2000; Astin and Philpin, 1985; Wallerstein, 2004; Arrighi, 1994). As Krahn and Lowe (2002, p.4) argue: "Some authors argue that factors internal to feudal society such as growing rural populations, deterioration of land, and landlords demanding more rent, forced people off the land and into the cities where they could form an urban working class. Others counter that as mercantile capitalism developed in urban areas, and as the market economy slowly began to make an impact on rural life, cites began to attract landless serfs. This debate is difficult to resolve, since the two processes influenced each other. What is undisputed is that capitalism brought with it an entirely new social order." Furthermore, as colony of France and later England, feudalism was never directly transplanted in Canada but was rather geographically and historically specific (Harris, 1966).
} 
village, where barter dominated, the centre of economic activity. As Rinehart $(2006$, p.23) notes: "Local markets, lack of agricultural surpluses, domestic production, a barter system, and workshop and artisanal production geared to personal orders - all combined to form a matrix that inhibited the development of 'economic man."' In other words, the direct producers often remained in control or at least possession of their means of production and conditions of labour, ensuring that the means of subsistence were sheltered from market forces. The transfer of surplus-value, where possible, often took the form of political or 'extra-economic' forms of extraction such as through customary norms, traditions, bonds, as well as political, military and religious forms of tax and tribute (Wood, 2002; Perelman, 2000). As such, the coercive mechanism was generally outside the realm of the economic as the nature of the transaction was by and large independent of the process of production.

By the midway point of the 19th century, the growing power of the mercantile class forced thousands of landless people into wage dependent forms of employment as farm labourers and workers in the construction of roads, canals and railways (Krahn and Lowe, 2002). For capitalism to become more dominant, the economic self-sufficiency of the agrarian countryside had to be broken down, that is, undermined or destroyed, as land was commodified and turned into private property. This required bringing market forces to the countryside, which would remove traditional rights and security over the means of subsistence and replace it with a dependence on capitalist markets. In this sense, the 1850s ushered in a period of transition from pre-industrial (or non-market) to capitalist forms of appropriation, which necessitated the creation of a working class. This process required transforming the majority of the population into wage-dependent workers by dispossessing them of their land, labour and resources. Formerly communal lands were thus unilaterally turned into private property and commodified. Activities connected to the staples trade, land speculation and control over the credit market worked to preserve the political dominance of office holders, traders and land owners. As the 1860s progressed, vast influxes of immigrant labour filled 
vacancies in the burgeoning industrial sector. Through this decade, small-scale craft production waned and the village economy slowly eroded as manufactories rapidly expanded, buttressed by new technological developments in steam-power, mechanization and forms of labour reorganization brought about by the Second Industrial Revolution (Hull, 1994).

However, the capitalist class remained weak and fragmented amid recalcitrant agrarian farmers, craftsworkers and an emergent urban working class, who resisted strict labour discipline and managerial rule. For capitalistic social relations to dominate, "Growth of production demanded unification in a central state. The grouping of scattered provinces no longer sufficed...In short, capitalist private enterprise was too weak to develop the productive forces. The central action of the state was needed." (Lipton, 1967, p.27). The administrative powers of the central state came to play an increasingly important role in the facilitation of capitalist accumulation. As Panitch (1977, p.9) has noted, "from its very beginning, the Canadian state has played a tremendously large role in fostering capital accumulation." These roles have generally revolved around four interconnected processes: First, providing consistent and reliable enforcement of contractual relations, monetary standards, and general fiscal conditions for economic growth via private enterprise. Second, underwriting the private risks of production at the public expense through grants, subsidies and depreciation allowances. This entails providing the necessary infrastructure for capitalist development when such undertakings are too risky or costly for private enterprise to assume. Third, maintaining a stable and predictable social order, while preserving favourable conditions for accumulation. This includes creating the conditions amenable to a capitalist labour market via control of land, immigration, labour and social policy. And fourth, employing the legal and juridical mechanisms, including control over the means of violence, to discipline and alleviate working class upheavals (Panitch, 1977; Jessop, 2002; Wallerstein, 2004; Wood, 2002; Boyer, 1996). These 
functions, then as now, played an integral role in subjugating ever larger masses and territories to the rhythms of capitalist development.

In other words, capitalism required that the state deepen and expand its central role in establishing and administering the juridical, regulatory and infrastructural frameworks through which private property, contracts and competition operated. What's more, the state came to ensure and maintain the necessary social conditions for economic growth and the reproduction of unequal power relations as structured between the capitalist class and those who must sell their labour power in order to gain access to the means of life. From commodifying previously exogenous spheres of social life to extending the terrain of market forces and promoting the long-run over short-term interests of the capitalist class, the state's role in the making of Canadian capitalism was from the very beginning central. This central role, however, required a degree of "relative autonomy" from any one particular set of capitalists' interests, thus the state was less the reserve of one particular class fraction (say, industrial or financial interests) than it was an ongoing "field of class struggle" (Panitch, 1977, p.196). Thus there had always been a very close relationship between the state and capital, and it is in this sense that the development of a 'ruling class' can be understood as the embrace of private capital and the state essentially functioned as one. Although the state came to take on a specifically capitalist form, it remained, despite its structural limitations, amenable to a narrow field of democratic reforms in light of working class demands.

For some, the 1870s represent the decade in which large-scale production first began to dominate the economic landscape in Canada (Rinehart, 2006; Krahn and Lowe, 2002; Kealey, 1995). ${ }^{2}$ From coast to coast, coopers, stonemasons, tailors, bakers, meatpackers, bricklayers, carpenters, moulders, shoemakers, cigar makers, printers and many others began organizing

\footnotetext{
${ }^{2}$ At the time of confederation four-fifths of the population was still located in the countryside, while roughly 13 percent were engaged in manufacturing and handicraft production and another 18 percent in the construction trades (Lipton, 1967, p.26).
} 
themselves into unions as manufactories gave way to full-fledged mechanization and large-scale manufacturing. As industry expanded, so too did employer efforts to lower wages, deny organizing rights and state efforts to clamp down on so-called radical behaviour (Palmer, 1992).

In an effort to quell the growing appeal of trade unions, both as centres of workplace militancy and broader ideological and political class struggles, the federal government passed the Trades Union Act (1872) which loosened some of the legal restrictions on unions. Prior to the legislation, unions had been prohibited organizations in restraint of trade and conspiracy. ${ }^{3}$ While the law was ambiguous and provided few legal protections that recognized the rights of unions to organize and bargain collectively, it did demonstrate to labour activists the progressive potential of legislative reforms. While the state intervened in an attempt to mitigate the growing politicization of labour - most clearly evident in mounting strike activity, demands for higher wages and official recognition - it did so as a result of mounting pressures from below which compelled legislative changes. These changes highlight the seemingly contradictory role of the state as an ongoing field of class struggles simultaneously expanding and contracting the legal parameters through which capital and labour struggle. Just as the Trades Union Act was passed, however, so too was the Criminal Law Amendment Act (1872), which essentially made picketing illegal and reinforced this with penalties where violence or intimidation (on the part of workers, but not employers) was alleged to have occurred during organizing drives and strikes. Moreover, the legal status of union contracts was such that they were unenforceable in a court of law (Lipton, 1967). All that to say,

\footnotetext{
${ }^{3}$ As Palmer (2003, p.473/4) has noted: "the 1872 legislation, which was after all a direct outgrowth of civil disobedience in the form of demands for the nine hour day that encompassed mobilizations of skilled workers in most major Ontario cities, a planned general strike called for May 15,1872, and the Toronto printers' conspiracy trial of April of that year, was indeed quite ambiguous in the legal sense. It granted unions legal status only if they followed certain legal guidelines, which none did, and it was quickly followed by other pieces of legislation that hemmed in what workers could do in strike situations. In reality, the 1872 Trades Union Act and subsequent follow-up legislation refused to easily concede the legal right of freedom of association and collective bargaining, with the consequence that almost the entire history of class relations and working-class self-activity in the 1870-1945 period was placed in legal limbo. This was a long, drawn-out interregnum, but it was one in which, interestingly, the zones of toleration and the boundaries of legal constraint that had limited trade union possibilities in the past were expanded greatly, at the same time that they were also hedged in more effectively vis-à-vis legal statutes."
} 
rather than extending and deepening the rights of trade unionists to organize and bargain collectively, the Trades Union Act had the contrarian effect of simultaneously embedding unions in extensive legal and penal structures, while simultaneously delimiting the tolerable means of union activity. As subsequent chapters show, this proved to be a blessing and a curse as legislative safeguards moved class conflicts out of the streets and into courtrooms depoliticizing the labour movement and increasingly relying on a professional stable of experts to bargain on behalf of rank and file members.

Through the 1870s, the Nine Hour Movement was gaining momentum and the first trade union central emerged with the formation of the Canadian Labour Union (CLU) in 1873. Consisting of largely craft oriented trades, the CLU began demanding shorter working hours, an end to immigration abuses by employers, protective legislation for women and children, an end to prison labour, the nine hour workday and a Dominion bureau of labour statistics. Labour militancy and union consciousness grew through the 1870 s. An additional legislative struggle, spearheaded by the CLU, was an effort to erase from the criminal code the Masters and Servants Act (1844), which made the decision to leave one job for another a criminal offence. The act of "deserting employment" or "breach of contract" was punishable by fines and jail. Perversely, however, if an employer did not pay wages for work done, unlike "servants" who were subject to both criminal and civil charges, "masters" were only subject to civil law and rarely prosecuted. In 1875 the CLU condemned this as "despicable class law." (Lipton, 1967, p. 42).

Through this period coercion by the state and employers intensified: blacklists, unjust dismissals, non-payment of wages, fines, jail time, anti-labour legislation, private militias, police violence and anti-communist propaganda were the preferred methods for quelling insurrection. In an effort to further "cheapen and subordinate labour, employers specialized and rationalized the work process, installing machines that replaced workers and reduced the need for skilled labour, 
and constructing a hierarchy of authority ranging from top executives to supervisors." (Rinehart, 2006, p.28). In response, individual and collective acts of resistance multiplied in the form of insubordination, subversion and sabotage (Palmer, 1992; Heron, 2012). Although the union movement grew slowly during this period, workers' demands over the right to organize and bargain collectively, safe and sanitary working conditions, and employment standards legislation continued to grow in importance.

Stimulated by the protective tariffs of the National Policy (1879), the federal state played an important role in stimulating and protecting certain sectors of the economy such as the Canadian Pacific Railway, building of canals and settlement of the west. As more workers left or were forced from the countryside, great numbers increasingly migrated to cities becoming wage dependent earners and consumers. At the same time, merchant-capitalists increasingly came to own the tools, machinery and buildings, and would hire workers to complete the finished products. Increasingly, then, workers no longer sold a finished product to merchants but rather their capacity to labour for a given amount of time. Gradually a national market began to emerge. And once again worker militancy escalated (Palmer, 1992; Heron, 2012). The preceding half-century had ushered in a world-historic political and economic transformation. As the ongoing proletarianization of the population increased, however, the 1880 s also renewed efforts by workers to improve their work and living conditions.

\section{Capitalism Takes Hold: Private and Public Sector Unions' Early Struggles, 1880-1929}

By the 1880 s capitalist methods of production grew rapidly as the state came to play an increasingly larger role in managing and superintending the organization of industry, agriculture, resource extraction and finance. As a consequence, issues related to labour legislation, employment standards and social welfare provision were slowly growing in importance. Through this period the capitalist classes consolidated control over the means of production and finance (Clement, 1977). 
As workers increasingly came under the control of the rhythms of capitalist employment, resistance against these impositions grew. "The specific material complaints by Canadian workers vary little from 1886-1919 - unemployment, low wages, high prices, long hours, unsafe and unsanitary working conditions, abysmal housing, super-exploitation of women, employer blacklists, nonrecognition of unions, refusal of collective bargaining - all remained a constant in the working classes bill of grievances." (Kealey, 1995, p.290). Employers used a variety of tactics in order to blunt or obstruct union drives such as non-payment of wages, mass dismals, use of strikebreakers, as well as legislated injunctions, police and private militia, the use of the Riot Act and Martial Law (Fudge and Tucker, 2001).

During the 1880 s, the Knights of Labour emerged as a trade unionism of a new type, geared to the unskilled and tending to organize on a plant rather than craft basis.

\begin{abstract}
"In their everyday engagements with local bylaws, employer boycotts, early closing legislation, lobbying for factory acts, various protective laws for women and children (whose meaning was always criss-crossed with gender and class content), strikes, and suffrage extensions, members of the Order were constantly both on the cusp of civil disobedience and working to reconstruct the law and legitimize it in the eyes of a working population more and more aware of the ravages of monopolistic power." (Palmer, 2003, p. 474-5).
\end{abstract}

Over the following decades the Knights of Labour were joined by the Industrial Workers of the World, One Big Union, as well as U.S. based locals such as the American Federation of Labor and Congress of Industrial Organizations, which injected into the Canadian labour movement a mixture of social democratic and socialist principles (Lipton, 1967). In 1883 the Trades and Labour Congress (TLC) emerged as the successor to the CLU as a Canada-wide labour federation.

Through this period labour and social justice activists continued to struggle for union recognition and improved working conditions and pay. However, the federal government refused to implement labour reforms citing a lack of jurisdiction as the constitutional divisions of powers enshrined in the British North America Act continued to bedevil the legislative process. In 1886, 
with latent class antagonisms bubbling to the surface, the federal government launched the Royal Commission on the Relations of Capital and Labor (Kealey, 1995).

Reporting three years later in 1889 , the commission's findings vividly detail the appalling industrial conditions, workplace dangers and abuses of employers (Kealey, 1995). Building upon the earlier suggestions of the 1882 Royal Commission on Mills and Factories, among the commission's suggestions were proposals outlining a maximum ten hour work day and fifty-four hour work week for children and women, a ban on employment for children under 14 , a moratorium on night work for children under 16, the abolition of fines, establishment of a bureau of statistics, and constitutional changes so as to allow for the adoption of pan-Canadian labour legislation (Palmer, 1992; Heron, 2012). The commission argued - just as the TLC and its predecessor the CLU had - that these proposals should be implemented Canada-wide or would risk given the nature of capitalism forcing regions and workplaces into cut-throat competition with one another.

Because competition lies at the root of capitalism trade unionists argued that unless regulations were implemented nationally, capital would shift its resources elsewhere in an effort to find cheaper resources and more easily exploitable pools of labour. Moreover, just as workers competed with each another to gain access to capital - a consequence of their market-dependence labour activists feared that without Canada-wide regulations regions would compete to attract corporations to their jurisdiction by lowering taxes, easing health and safety standards, dispensing with minimum wage laws, environmental standards and trade union rights. Labour continued to demand such legislative reforms through the late-1800s arguing that in the absence of uniform regulations regions would compete with one another to dismantle and lower existing standards. For these reasons, labour activists held that regulatory harmonization across the provinces would provide the ultimate terrain through which further labour struggles could be waged. Without basic legislative minimums, labour would continue to be subject to the unbridled imperatives of capital. 
Despite these concerns, the Conservative government of Sir John A. Macdonald did not follow through on any of the report's recommendations claiming that acting on them would infringe upon provincial jurisdiction (Palmer, 1992; Kealey, 1995).

Through the 1890 s capitalist economic and political power continued to coalesce with state coercion. Over this period the gulf between labour activists inclined toward social democratic reformism and those expounding an alternative, socialistic developmental path widened. ${ }^{4}$ This evolving rift was sharpened by employer and state efforts disavowing trade union socialism as against the Calvinistic work ethic espoused by Canada's early forbearers (Caplan, 1973; Campbell, 1999). These disunifying efforts sought to impede the formation of a unified and class-conscious proletarian espousing a socialist alternative. By the late $1800 \mathrm{~s}$, most workers remained in a state of insecurity, poverty and oppression as Canada's industrial frontiers and cities grew, often finding themselves worse off than their predecessors a generation earlier (Palmer, 1992). In 1900 the federal government finally established a Department of Labour, something labour activists in the CLU had been fighting for for more than a quarter-century. William Lyon Mackenzie King was installed as the Department's first Deputy Minister of Labour and, following his election to parliament in 1908, the first full-time Minister of Labour. The creation of a Department of Labour, and with it King at the head of the helm, ushered in a new era of government intervention in dispute settlement.

Central to this was the crafting of the Industrial Disputes Investigation Act, 1907 (IDIA) which "prohibited strikes and lockouts pending the completion of an investigation of the contested

\footnotetext{
${ }^{4}$ As Lipton (1967, p.92-3) notes: 'Socialists argued that unions should advance to political action. The rise of the trusts and their increasing power in government proved that the purely economic struggle no longer sufficed. When labour confined its battles to the economic base, it tended to be outmaneuvered by capital which operated not only from its own powerful base, but also from the reserve political base of government and the state. The solution was that the workers should marshal their forces on a Canada-wide scale and constitute themselves as an independent force in Canada-wide politics" On the other hand, social democrats argued that electoral reforms could mediate the power of capital, with the state serving as an 'impartial umpire', while some went as far to argue that parliamentary changes could bring about socialistic changes (Caplan, 1973).
} 
issues in each case and attempts at conciliation by a board consisting of representatives of labour, employers and the government. If the dispute was still unresolved, the law required 30 days' notice before a strike or lockout could be legally staged." (Rinehart, 2006, p.46). ${ }^{5}$ The failure to comply with the provisions of the Act could be met with fines and jail time. Emerging in tandem with the new provisions of the IDIA were new workplace organizational methods popularized by the ideas of Frederick Winslow Taylor. Taylor's "scientific management" was primarily concerned with maximizing economic efficiency and thrift as it pertained to the labour process. He set it upon himself the task to find the "one best way" to do any given task and implemented a variety of "time and motion" studies to reveal such insights (Taylor, 1911). But beneath the otherwise pleasantsounding exercise in thrift and workplace reorganization was an attempt to "deskill" and intensify the labour process by employing various techniques enabling the transfer of knowledge from workers to management, separating execution from conception and increasing the tempo of work. In seeking to breakdown the labour process into small component tasks, Taylor's managerial practices served to further alienate workers by intensifying monotonous and repetitive activities (Rinehart, 2006; Braverman, 2008). It is in this light, as Craven (1980) has argued, that the appointment of King as labour minister ought to be understood. Trained in the "expert" managerial practices of the day, King sought to institute insights gleaned from the emergent school of scientific management.

In the view of King, the state's role was to act as an "impartial umpire" in capital-labour disputes (King, 1918; Craven, 1980). Whether out of naïveté or ulterior motives, it was clear from the beginning that the crafting of the IDIA did not hold such benign intentions. Rather, while seeking to ensure that social instability did not endanger the viability of capitalist production, the Act sought to dissuade workers from joining unions by showcasing the interventionist capabilities

\footnotetext{
${ }^{5}$ The IDIA also banned strikes or lockouts during the term of a collective agreement, and made strikes or lockouts illegal in key industries (transportation, communications, mines, public utilities) until a board of inquiry had examined the problem and its conciliation report had been made public.
} 
of the state. King was well aware that for capitalism to spread and grow unions must be incorporated into the vast legislative machinery of the capitalist state. He wrote of "the danger of this whole body being converted to socialism if employers fail to take them into a sort of partnership through agreements with recognized unions." He continued: "The solution of the problem of strikes seems to me to lie along the business partnership arrived at by long term agreements between responsible leaders of organized capital on the one side and organized labour on the other. The trade unions must be incorporated and limits put on the right to strike without compliance and with safeguards in the constitution..." (King cited in Kealey, 1996, p.430).

Despite the Act, however, employers were still free to ignore unions, deny responsibility for workplace injuries, unilaterally discharge sympathetic workers and employ strikebreakers in the event of a conflict. Moreover, "While the major [strike] weapon of workers was blunted, the IDIA contained no prohibition of employers' anti-union tactics, such as the use of scab labour, injunctions, victimization of unionists, or yellow-dog contracts. As a result of the act, striking workers found themselves confronted with a more or less united opposition of both employer and state." (Rinehart, 2006, p.46).

Coupled with Taylorism, the extension of labour practices refined by Henry Ford served to further alienate and oppress workers. Fordism increased mechanization by replacing earlier crafts work with automated production, simplified and routinized the labour process, as well as vertically integrated large-scale industrial activity on an expanding scale (Aglietta, 1979; Lipietz, 1987; Jessop, 1990). While large-scale assembly-line productive systems were refined in the first decade of the 20th century, Harvey (1990, p.125) has suggested that Fordism genuinely came to fore when Henry Ford introduced the eight-hour, five-dollar workday for employees on his new car assembly line in Michigan. Fordism was premised on the assumption that mass production would equal mass consumption. And for a certain period in time, for some, increasing scales of production coupled 
with wages allowing for the purchase of consumer goods did lead to increased aggregate demand and larger profit margins. Moreover, paying workers wages which allowed them to yield a portion of their social surplus product facilitated their integration and subordination to the logic of capital, while assisting in the stabilization and routinization of the capitalist system as a whole. As Taylorism and Fordism coalesced, workers' abilities to resist capitalist and management prerogatives were increasingly weakened. Large waves of immigrant labour and, in particular, women were increasingly being used as cheap and disposable sources of labour (Sangster, 1985; Parr, 1985). The same was true for immigrants such as Chinese railroad workers, Japanese fishers, Ukrainian farmers, Italian construction workers and so forth, supported by an overtly prejudicial immigration system which directed them into the most dangerous, menial and arduous forms of labour (Iacovetta, 1992; Whitaker, 1991). In light of the IDIA and capitalist militancy, by the early decades of the 1900s the trade union movement had reached an impasse.

It is important to recall that public sector associations had largely been organized as social clubs, benefit societies and cooperatives. For example, the Civil Service Rifle Association (1861), Railway Mail Clerks Association (1889) and Federal Association of Letter Carriers (1891) were all early examples of workers coming together to pool their resources and purchase bulk items such as oil, coal and various foodstuffs, as well as engage in recreational pursuits, arts and cultural activities (Frankel, 1962). Associations were largely organized along departmental lines and job classifications. As some associations grew, they began to merge with other associations. For instance, customs and excise workers organized themselves nationally in 1917 with the founding of the Dominion Customs and Excise Association, as had postal workers in 1912 with the formation of the Federal Association of Letter Carriers, as did clerical workers and general office staff in 1909 becoming the Civil Service Federation (CSF). In 1919 the Professional Institute was founded as a loose amalgam of scientists, technicians and other specialists. Of interest, too, was the founding of 
the Amalgamated Civil Servants of Canada in 1920 who had been inspired by the more militant and radical strands of the IWW and $\mathrm{OBU}$, and had sought to organize across departmental lines, classifications and workplaces. Despite the early formation of such associations, there have been few scholarly attempts examining their origin and development resulting in notable gaps in the historical literature (Hodgetts et al, 1972; Arthurs, 1971; Palmer, 1992).

Nevertheless, as the forceful expulsion and creation of a market-dependent working class continued, workers in the federal public sector did not demonstrate the same level of militancy or discord as their industrial counterparts. From confederation to WWI, patronage appointments to the public sector were common (Dawson, 1929; Arthurs, 1971; Frankel, 1962; Granastein, 1982). The most widespread form of patronage was political nomination whereby loyal party members were appointed to a position in the public sector based on the extent of the nominee's party backing and support. Nevertheless, for most public sector workers there remained few opportunities for career development and upward advancement absent a close relationship with management and elected officials. Despite the early formation of public sector associations, most remained ineffective in advocating on behalf of their members preferring to rely on the generosity of elected officials As the next general election came around in 1911, "efficiency in government" was the central policy plank across the political spectrum (Hodgetts et al, 1972). Private interests actively intervened through the debates in order to ensure a favourable business climate. ${ }^{6}$ With the defeat of Laurier's Liberals and the election of the Borden-led Conservatives hopes were high for the elimination of overt political patronage. These hopes, however, proved unwarranted. With the outbreak of WWI, it

\footnotetext{
${ }^{6}$ For example, in light of the Laurier government's decision to introduce trade reciprocity with the U.S., a group of prominent Toronto businessmen, many of them associated with the Canadian Northern Railway project, formed a committee known as the Toronto Eighteen to press for the elimination of patronage in order to establish organizational efficiency in the public service so that a strong and competent government and civil service could effectively advance the interests of Canadian businesses abroad. Having drafted the Manifesto of the Toronto Eighteen which called for a continuance of Canadian nationalism, since free trade was likely to undermine their railway dominance, they 'believed that a stronger and more efficient government and civil service were essential for opening up markets abroad'. (Hodgetts, 1973, p.46).
} 
is estimated that the government took advantage of the wartime emergency to swell the ranks of the federal public sector with between 16,000 and 23,000 politically motivated nominations (Dawson, 1929; Frankel, 1962).

By 1918 significant pay discrepancies in the broader public sector, a lack of promotional opportunities, grievance procedures and insecurity of tenure were common facets of employment (Hodgetts et al, 1972). Overt discrimination against French-Canadians, Catholics, immigrants and women resulted in job ghettos and rates of pay at half the rate of married, Anglo-Saxon men (ibid). From confederation to 1918, no less than six major inquiries and royal commissions into the federal bureaucracy dealt at length with the "scourge of patronage" (Dawson, 1929).

From the beginning to the end of the Great War, federal employment had nearly doubled from 22,621 to 41,825 (Hodgetts et al, 1972, p.66). With a new act in hand, the recently established Civil Service Commission (CSC), for example, developed new methods of uniform cost accounting, job classification, hiring, pay, promotion and grievance procedures. In order to undertake this task, the CSC employed the firm Arthur Young and Company, a leader in the emergent field of "scientific management." What resulted was a massive tome totaling "678 pages, listing about seventeen hundred separate classes. Class titles along with definitions were provided, as well as sample duties. A statement of minimum requirements was included, dealing with education, experience, technical knowledge, and special aptitudes. Lines of promotion were enunciated, showing the next highest as well as the next lowest position, and a salary schedule was appended to each class." (Hodgetts et al, 1972, p. 69). This represented a radical and in many ways pioneering use of scientific management in the organization of work and labour as the public sector was transformed in a wide-ranging and heretofore unseen manner.

The new classification, pay, promotion and tenure system was one of the first instances where public sector associations began voicing, albeit in a mild manner, their general discontent 
with the pay scheme being developed by the consultative company. ${ }^{7}$ The firm had assumed that wartime inflation would return to pre-war levels and had based their pay scale on such assumptions. However, the inflationary rise in the cost-of-living did not dissipate following the war. In response, various associations began letter writing campaigns and personal appeals to deputy ministers, upper management and members of cabinet (Arthurs, 1971; Frankel, 1962). Eventually the associations' efforts paid off, leading to a minor increase in pay. However, the new classification system remained in place. In the 1920s, the Civil Service Federation (CSF) - the largest of all federal associations and forerunner to the Public Service Alliance of Canada - began raising the issue of "equal pay for equal service", although this appeal did this not extend to women and immigrants. Such concerns went largely unheeded by government who continued to unilaterally determine working conditions and rates of pay. In fact, by 1921 formal restrictions on female labour in the public sector had been enacted forbidding married women from employment. Women who had permanent positions were forced to resign, since they were assumed to be the 'responsibility' of their husbands (Hodgetts et al, 1972). This overt policy of discrimination remained in place until 1955.

Since the various associations were largely organized on a departmental basis this weakened their ability to adequately deal with the conditions of their employment, pay and promotion in a collective manner. Not only were discussions with management impeded by the geographical dispersion of workers but the various often overlapping associations prohibited a unified position. This further reinforced management prerogatives, while leading to internal strife among competing associations. Through the 1920 s nearly all of the public sector staff associations pursued a policy of

\footnotetext{
${ }^{7}$ Arthur Young and Company, and its successor, Griffenhagen and Associates, would continue to regularly be subcontracted to undertake consultative work to "implement up-to-date business principles and practices", including the vertical integration of various departments through the 1920-1940s. (Hodgetts et al, 1972, p.72-80).
} 
appeasement and avoided criticism of management (Dawson, 1929; Arthurs, 1971). ${ }^{8}$ In fact, the largest association, the CSF, went so far as to urge its members to deal with issues related to remuneration, promotion, transfer, tenure and the like on an individualized and departmental basis, significantly departing from the confrontational and collective struggles of their private sector counterparts. ${ }^{9}$

Much like the case federally, the early history of Ontario's public sector workforce is littered with examples of patronage and nepotism (Scarrow, 1957; White, 1985). As Hodgetts (1995, p. 185) has convincingly argued in the case of Ontario: "Patronage, in the view of many politicians, especially when in power, was the perfectly proper exercise of personal discretion to choose your own trusted advisors and not to leave the selection to an 'irresponsible' (because independent) commission." In other words, patronage was largely seen as a legitimate function of the executive's power to appoint and reappoint those who would be running the day-to-day machinery of the public sector. By the turn of the 20th century the public sector had experienced otherwise modest growth increasing in size from 553 in 1871 to 816 staff in 1892 and 1,245 employees by 1905 (Hodgetts, 1995, p. 86-88). Unlike federal public sector associations which began appearing in the quartercentury before confederation, Ontario public sector workers' associations did not formally begin to

\footnotetext{
${ }^{8}$ Two major exceptions were the Associated Federal Employees of Ottawa (AFEO) and the various letter carriers associations such as the Railway Mail Clerks Association and the Federal Association of Letter Carriers. In response to the rather facile collaboration by the CSF with management, in 1920 the AFEO was formed out of an amalgam of discontented elements in other associations. The AFEO was the only civil service association affiliated with the TLC (and remained so until the 1950s) and was a fervent supporter of labour struggles in the industrial sector. In light of the AFEO's discontent with unilateral management protocols, they advocated the introduction of a joint advisory council as the only adequate means of resolving disputes between management and employees (Hodgetts et al, 1972). Like the AFEO but going one step further, the letter carries associations advocated for full-blown trade unionism and were thus marginalized within the federal public sector (Arthurs, 1971; Hodgetts et al, 1972; Frankel, 1962).

9 For example, in the association's official publication, the Civil Service News, the CSF argued that workers were essentially paid what they deserved and if they felt undervalued they should take such matters up with deputy heads rather than rely on the association for improving wages. The CSF's aversion to joint councils stemmed from the fact that they smacked of trade unionism of the type being fought for in the private sector. Aside from the CSF's general opposition to unions, they preferred to rely on the paternalistic appeals to management for workplace improvements rather than the 'radical' measures of industrial unions. The CSF went so far as to publically distance themselves from the militant position of the AFEO through union newspapers, editorials and magazines, despite the fact that the AFEO maintained that such joint councils, for example, should be strictly advisory and voluntaristic (Hodgetts et al, 1972).
} 
appear until the turn of the century. ${ }^{10}$ Given the austere climate that prevailed at Queen's Park, Ontario's public sector grew much slower than their federal counterparts.

Most associations at the provincial level remained relatively inactive as an organizing body on behalf of their members until after the First World War. This was true, in particular, in the case of the Civil Service Association of Ontario (CSAO), the largest association and forerunner to the Ontario Public Service Employees Union (Roberts, 1994; Hodgetts, 1995). By this point, the Ontario government had slowly begun centralizing some of the administrative and social welfare responsibilities formerly provided by the municipalities and had launched, for example, the HydroElectric Power Company, the Toronto Transit Commission and the Workmen's Compensation Board in 1914. Municipal workers' associations, by and large subject to the provisions of general labour relations statutes, were among the most active of public sector workers as is evidenced by the burgeoning public works and utilities sectors, hydro-electric generation, transit and correctional facilities workers, which had been demanding the right to organize and bargain collectively since the early-1900s (Frankel and Pratt, 1954). ${ }^{11}$ This injected some radicalizing influences into the public sector, albeit in an uneven manner, as well as implicitly compelled provincial public sector workers (particularly those associated to the CSAO) to take a more militant posture given the aggressive organizing drives by the National Union of Public Employees (NUPE) and the National Union of Public Service Employees (NUPSE), the forerunners to CUPE (Frankel and Pratt, 1954; Roberts, 1994; Ross, 2005). By the 1920s, one in 10 public sector workers were women and, for the most part, many remained isolated in lower-paying positions with fewer opportunities for promotion

\footnotetext{
${ }^{10}$ The reasons for the delayed introduction of public sector associations in Ontario are not well documented. Like the study of public sector association formation federally, few studies examine the origin and development of the early public sector associations at the provincial plane and, to a lesser extent, municipally. Hodgetts et al, (1973), Arthurs (1971) and Dawson (1929) are nevertheless useful starting points.

"Because municipal "corporations", as they are formally called, were never regarded as sovereign political entities they were creatures of the provinces subject to the rights and powers conferred to them by the province. As such, municipal labour relations in the main fall under general or private sector labour relations statutes (Arthurs, 1971).
} 
as Catholics, French-Canadians and other immigrant groups were relegated to the bottom rungs of the public sector (Frankel and Pratt, 1954; Hodgetts et al, 1972)

It was becoming increasingly apparent, however, that the turnover of public sector staff impeded the development of a professionalized workforce. In response to mounting dissatisfaction among public sector associations and opposition parties, the Ontario government amended the Public Service Act (1909), which since 1878 had allowed ministers to unilaterally fine and dismiss workers for "misbehaviour." The amendment sought to limit patronage appointments, and install competitive examinations as the guiding principle for appointment to the public sector. Most associations, such as the CSAO, applauded the move as a step in the right direction (ibid).

In 1918 the Public Service Act was once again amended. This time the Act strengthened the qualifying examinations for entry into the public service and also created the Office of the Civil Service Commissioner (OCSC). A year later, with workplace upheavals mounting in the private sector, the Ontario government also launched its first Ministry of Labour. In line with their counterparts in Ottawa, the government of Ontario immediately set upon a path toward Taylorizing the public sector. For example, J.M. McCutheon, the new Office of the Civil Service Commissioner, embarked upon a plan of reorganization, restructuring and retrenchment. Over the next five years, McCutheon sought to standardize salaries, rearrange administrative duties, institute means-tested examinations for tenure and promotion, and implement a merit system for the selection of candidates. While some civil service associations mildly voiced their displeasure, particularly the CSAO which slowly grew more emboldened and confrontational, these changes in the 'efficiency of government' would set the tone of work and labour in the provincial public service for years to come (Roberts, 1994). 
Emerging from World War One, the economic downturn which introduced the 20th century would finally be overcome (Palmer, 1992). Smaller workplaces such as family-owned and selfemployed artisans were rapidly disappearing as full-blown industrialization emerged. The mass production of munitions led to the rapid adoption of assembly-line production, employer "speed ups" and other "efficiency" measures designed to squeeze more labour out of workers. For example, during WWI 60 percent of munitions production employing some 185,000 workers were located in Ontario. In 1916, 2,000 workers in Hamilton, the strategic centre of wartime production, struck at over 30 plants engaged in the production of war armaments. While the strike was ultimately unsuccessful in raising wages and improving working conditions, it did advance working class consciousness and workers' struggles in favour of the nine-hour work day (ibid).

The massive growth of industry, warehouses, factories, rail and harbour facilities, stimulated by the cheap availability of credit, set in motion vast technological, administrative and organizational changes to the work and labour process. As the war waged, labour was suddenly in high demand. While corporate profits soared, so too did the cost of living. This served to fan the flames of workplace militancy and revitalized the dormant state of labour prevailing at the time. ${ }^{12}$ The war years were a period of massive strike activity and renewed efforts seeking union recognition in the workplace and in a court of law.

\begin{abstract}
"By 1919, new traditions, especially those associated with Marxism and its language of production for use, not profit, were being absorbed into the more revolutionary variants of class struggle, and internationally the actuality of world war and the threat of Bolshevism and Revolution was very much in the air... Canada's political economy was revamped: the flooding of the labour market by a massive influx of immigrants, a huge jump in productive capacity associated with Canada's second industrial revolution, the expansion of workplace size, numbers of corporate mergers, technologies and managerial rigour, the consolidation of a Department of Labor, and the acutely legal role of William Lyon Mackenzie King in mediating class tensions in the preWorld War I years all figured forcefully" (Palmer, 2003, p. 476).
\end{abstract}

\footnotetext{
12 "Yet World War I, while providing specific sparks to light the flame of working class struggle in 1919, should not be viewed as its cause. Underlying structural changes in capitalist organization, both on a national and international scale, must be viewed as providing the necessary fuel for this fire. Indeed, although the years 1914 to 1916 had seen little overt class conflict in Canada, the changes in the capitalist organization of production and the consequent "remaking" or reconstitution of the working class was well advanced before the outbreak of war. The years 1912 and 1913 should be seen as a prelude to the 1917 to 1920 conflagration." (Kealey, 1995, p.294).
} 
In the years that followed the labour movement witnessed a new peak in labour militancy and civil disobedience. This culminated in the 1919 Winnipeg General Strike, which formed part of a broader pan-Canadian movement. ${ }^{13}$ Between 1915 and 1919 union membership nearly tripled and strike activity increased every year. By 1921 nearly 16 percent of the non-agricultural workforce was unionized (Kealey, 1995). As a result of concerted employer and state efforts to restrict unionization, however, this number would decrease though the 1920 s to be surpassed only in the later half of the 1930s .

Despite the militancy in the private sphere, a good many public sector associations worked to distance themselves from the broader labour movement and working class politics more generally. It is important to stress, however, that public sector unions - like their private sector counterparts - were not organized in a homogenous fashion. Each association encountered their own unique set of challenges and constraints along the path toward unionization. While this specificity is important and cannot be overlooked, some common challenges encountered by public sector associations and their reasons for distancing themselves from the broader labour movement and working class politics can nevertheless be drawn. First, because the relationship between elected officials and public sector workers was often a direct or closely associated appointment, public sector employment depended on the ability of workers to reflect the political interests of their employers in office. Thus it was necessary that public sector workers, particularly those in higherpaying and well-regarded positions, tow the appropriate party line. Second, and related to the first, because the public sector was geographically dispersed across the country and across the provinces many workers came to associate their interests with elected officials and those in managerial

\footnotetext{
${ }^{13}$ As Kealey (1995, p.310) notes: "It was no more limited to Canada than it was to Winnipeg within Canada. In the years from 1917 to 1920 , a working class-movement whose internationalism had been destroyed in 1914, ironically responded with an international surge of class militancy which knew no national limits and few, if any, historical precedents." In addition to being inspired by the Russian revolution of 1917, newly arriving immigrants brought with them the experiences of revived workplace militancy in Germany, Italy, France and Britain.
} 
positions who they daily interacted with on a personal basis, as opposed to a similarly employed counterpart in another region. This personal relationship between employer and employee inhibited the formation of a collective (class) consciousness among workers, often present among their counterparts in the private sector who lived and worked in close proximity to one another.

Third, because public sector workers generally had superior pay and working conditions than workers in the manufacturing industries where unionism was booming, they sought to identify with political and economic elites (whose successes they were dependent on), thus differentiating themselves from the 'radical' labour movement and their proximate association with working class politics. This was also reflected in the emphasis of public sector workers to identify themselves as associations, institutions and federations, thereby symbolically detaching themselves from the radical (because confrontational) labour movement. This served to reinforce the divisions among many public and private sector workers, which often continued to struggle in isolation from one another.

The preceding half-century of private and public sector workers' early struggles were characterized by varying degrees of success and failure. While industrial unions inched ever-more gradually toward confrontational and militant tactics, including a growing political awareness and working class consciousness, the bulwark of public sector unions remained diffident amidst the false security of paternalism and marginally advantageous wages and benefits. While the gains afforded to private sector unions and their public sector counterparts were uneven and heterogeneous through the $1920 \mathrm{~s}$, the following decade would result in an impasse of sorts as capitalists (and the system as a whole) experienced a crisis of accumulation and legitimation. 
From Great Depression to Deficit-Spending: Public Services and Workers' Struggles for Union Recognition, 1930-1945

After more than three decades of unparalleled economic growth - largely spurred by WWI the Great Depression radically halted the expansion of capitalism. By 1933 one in four workers were unemployed and half the working age population was on some form of relief. In Ontario, unemployment rose from 2 percent to 36 percent between 1929 and 1932. What Burton (1990, p.25) has called a "building binge" resulted in an overabundance of railway stations and hotels, skyscrapers and factories, and overstocked consumer goods. Likewise, with the introduction of the automobile, roads were built on borrowed funds, new suburban homes were financed with mortgage loans, and the stock market was fuelled with borrowed cash. But when these companies went bust, Burton (ibid) reminds, "it was the taxpayers and not the bondholders who were saddled with crushing debt." As the Depression grew deeper, there was an international turn toward protectionism as high tariffs pushed the cost of exports ever higher. When R.B. Bennett became Prime Minister in 1930 phrases like "fiscal responsibility" and "government prudence" took on an even sharper meaning as all levels of government tried to pass the responsibility for relief on to one another and the poor (ibid).

Given that relief was customarily the purview of provincial and municipal governments or volunteer groups, Bennett unwaveringly argued that people should not look to the government to take care of them. Idleness and the inability to find work was thought to be the result of poor moral foundations and the absence of a Protestant work ethic (Abella, 1973; Penner, 1988). P.M. Bennett tried to export the Depression's problems away by turning to the usual scapegoats during times of crisis: immigrants and "radicals." From 1930 to 1935 Canada deported more than twenty-eight thousand people who were thought to be communist sympathizers or on some form of welfare relief (Burton, 1990). Bennett vowed to crush under the "iron heel of ruthlessness" an alleged communist 
conspiracy. "Canada become the first country with parliamentary institutions, apart from Japan, to outlaw communist organizations and to declare their property, belongings and facilities subject to confiscation." (Burton, 1990, p.126). ${ }^{14}$ Section 98 of the Criminal Code gave authorities the power to jail anyone attending meetings of any organization advocating revolutionary social change and used the legislation to detain and imprison countless trade union leaders, socialists and activists. Moreover, fearing general unrest and "communist subversion", Bennett segregated unemployed men in isolated work relief camps under militaristic and otherwise slave labour conditions. As despair grew, governments at all levels preferred to fight the spectre of deficit over widespread unemployment.

The Royal Commission on Price Spreads and Mass Buying (1935) painted a grim picture of the state of working conditions and wages. The Price Spreads Commission gave countless examples of employers using the Depression as an excuse to cut wages, turn to part-time employment and subvert the minimal legislative safeguards in place (Saywell, 1992). As usual, women and immigrants were among the frontlines of workers facing sweatshop conditions and extreme authoritarian employers. Like Bennett, new Premier of Ontario Mitchell Hepburn used work relief camps to cast young men out of the cities and into remote areas (ibid). The failings of the freeenterprise system were becoming clearer by the day. Furthermore, "The comparative generosity of the Americans ['New Deal'] stood out in sharp contrast to the Calvinistic Canadian attitude, which held that people on public charity must never be allowed to think they were getting something for nothing. There must be no frills, no 'luxuries'." (Burton, 1990, p.276) Despite a last-gasp renunciation of laissez-faireism by Bennett, the return of King to office in 1935 was far from a

\footnotetext{
${ }^{14}$ The most infamous of these is Quebec's "Padlock law", which granted the Attorney General discretionary powers to seize any property or home allegedly associated with disseminating communist propaganda. See Penner, 1988
} 
duplication of Roosevelt's 'New Deal'. ${ }^{15}$ However, by the second half of the 1930s labour had once again began demanding a greater share of the wealth which they were producing. Having regrouped themselves they began demanding improved work and living conditions, and the right to form trade unions.

In 1935 the On-to-Ottawa trek redefined the political possibilities available at the time by capturing the popular imagination of the downtrodden and destitute (Waiser, 2004). A year later a bout of sit-down strikes, plant occupations and other militant outbursts erupted across the country as the employed and unemployed, many of them trade unionists, the homeless, relief dependent poor as well as immigrants and communists began agitating for a 'New Deal'. In the auto, mining, rubber, steel, electrical and chemical industries bursts of workplace radicalism inspired acts of militancy. Perhaps best enigmatic of such struggles was the General Motors (G.M.) strike on August 8, 1937 where 4,000 workers struck against G.M.'s refusal to grant wage increases, improve working conditions and recognize the union (Gindin, 1995)

Despite G.M. workers being subjected to Taylorist managerial prerogatives, worker speedups and a 5 percent pay cut in the years preceding the strike, the company was aided by Ontario Premier Hepburn who vowed that no CIO-affiliated union (i.e. the United Auto Workers - UAW), would ever be allowed to unionize in 'his' province (Colling, 1995). Despite repeated requests by Premier Hepburn, P.M. King refused to send in the Royal Canadian Mounted Police (RCMP) and military fearing a significant political backlash. In its place, Premier Hepburn assembled a 'volunteer' militia, branded "Hepburn's Hussars" or "Son's of Mitch's" to march on Oshawa. Through the strike Premier Hepburn pleaded with the president of G.M. not to recognize the UAW

\footnotetext{
${ }^{15}$ In the midst of the 1935 general election, Bennett opportunistically embraced a greater role for government: "The old order has gone. It will not return....Your prosperity demands corrections in the old system...In my mind reform means government intervention. It means the end of laissez-faire...There can be no permanent recovery without reform....Free competition and the open marketplace, as they were known in the old days, have lost their place in the system and the only substitute for them....is government regulation and control." (Burton, 1990, p.283). Political opportunism aside, these comments came too little too late as Bennett's preceding term contrasted sharply with his sudden change of heart in the midst of a failing political campaign.
} 
union vowing he would "root communism out of the Canadian labour movement." (Burton, 1990, p.408). After two weeks on strike (23 August) workers had won union recognition, an increase in pay and benefits, grievance procedures and minor improvements in workplace health and safety standards. For some, the conclusion of this strike heralded the entrenchment of industrial unionism (Colling, 1995; Abella, 1973).

While overt political patronage in the federal and Ontario public sectors had largely been eliminated by the 1930s, unlike their militant industrial counterparts public sector workers' associations were slower to employ direct confrontation tactics with management and tie those concerns to broader political initiatives (Franks, 1962; Arthurs, 1971; Hodgetts et al, 1972). With the onset of the Great Depression, the first major bout of federal and provincial austerity slowly began politicizing the public sector associations. ${ }^{16}$ As Hodgetts et al. $(1973$, p.140) have written: "The restoration of business confidence was the main theme as the most extreme austerity on the part of the government was believed to be the key to such a restoration. Even the academic economists of the day fully backed such views. The Bennett Government accordingly gave highest priority to reducing the cost of Government and balancing the Federal budget." The Bennett government cut salaries across the public sector by 10 percent, reduced administrative expenditures across departments, put an end to all promotions and pay increases, and used unemployed workers as a source of short-term, temporary and contract labour. Likewise, in Ontario Premier Hepburn set upon a similar path toward austerity: wages were cut across the civil service anywhere from 5 to 35 percent, all employees hired after 1933 were fired, and a show of 'thriftiness' was made with the sale of all government limousines (White, 1985; Roberts, 1994).

In the early years of the Depression the activities of most public sector associations had largely been subdued as public workers clamored to be included in governments' 'good books'

\footnotetext{
${ }^{16}$ In 1930 a Royal Commission on the Public Service was launched to investigate the pay and working conditions of public servants, however in light of the Depression the Commission lapsed into inactivity never having filed its report.
} 
(Franks, 1962). Some exceptions were municipal unions and associations which commonly fell under general labour relations statues and were therefore exempt from the more rigid limitations imposed on civil service workers proper (Ross, 2005; Frankel and Pratt, 1954). Notwithstanding some exceptions, the Great Depression further curtailed the already limited ability of public sector workers' associations to engage in meaningful discussions with management since, in general terms, ultimate authority resided with cabinet. However, with the entry of Canada into WWII and the implementation of the War Measures Act, administrative powers quickly concentrated under the purview of the federal state.

'The War Measures Act converted Canada overnight from a confederation into a unitary state; the government overrode or supplanted most of the normal procedures of peace; it became the largest and much the most important employer of labour; it used its fiscal capacity and monetary powers to effect maximum war production; borrow billions, raising billions by taxation, and then bringing into play a reserve power by borrowing many millions from the banking system to inflate the economy to full war capacity' (Eggleston in McInnis, 2002, p.21).

Between 1938 and 1944 federal public sector appointments rose from 4,406 to 56,342 (Hodgetts et al, 1972, p.180). Suddenly workers were in high demand throughout the economy, and in particular the public sector, as the burgeoning departments of National Defense, Munitions and Supply, and the Post office, for example, rapidly expanded. The war economy boosted employment and raised economic output as the fetters of laissez-faireism were cast aside.

"In the tenth year of the Great Depression, Canada reached a turning point. This was the year in which the government of Mackenzie King moved hesitantly and reluctantly toward the liberal welfare state. It was also the year in which - again hesitantly and reluctantly - it began to come to terms with John Maynard Keynes' radical concept of cyclical budgeting." (Burton, 1990, p.433). In earnest, this move began a few years earlier with the centralization of the Bank of Canada in 1938, which recognized the dangers of leaving the control of the money supply to bankers and financiers - that is, in the hands of private interests. The Royal Commission on DominionProvincial Relations, called in 1937 and reporting in 1940, made clear that while the federal 
government enjoyed the largest means of revenue generation the provinces were tasked with most of the largest expenditures (Rowell and Sirois, 1940).

The Commission recommended that the federal government take over unemployment insurance, pensions and look to creating an equalization system. Although various provinces, in particular Ontario and Quebec, remained resistant to such changes, the federal government bypassed them going directly to the municipalities and issuing municipal improvement grants and national housing assistance subsidies. Through the early 1940s family allowance grants and pensions were increased, and a federal unemployment insurance system was launched in 1940 (Campbell, 1987). Gone were the tight fiscal leashes restricting spending as Canadians began demanding more in the form of social spending, a greater share of wages and dignified working conditions. Gradually a new ethos of collective responsibility emerged, spurred in good part by the collective efforts of trade unionists and socialists expounding the virtues of cooperation as opposed to competition.

Suddenly deficit-spending had come to replace the straightjacket of classical liberalism as the federal state began to play a more active and interventionist role in the economy with the establishment of the Canada Wheat Board, Canadian Broadcasting Corporation, National Film Board and Trans-Canada airlines. As the procurement of social welfare initiatives spread, so too did workplace efforts to improve wages, working conditions and benefits. What was emerging was a cultural shift which had been initiated decades earlier as trade unionists and socialists struggled against the imperatives of capital.

Through the war, however, public sector workers' wages generally stagnated leading many of the associations to begin advocating for the creation of joint-advisory councils (Hodgetts et al, 1972). On February 24, 1944, the King government, fearing the extension of industrial militancy into the federal public sector, and after more than a decade of appeals by public sector associations, 
announced the creation of the National Joint Council (NJC). ${ }^{17}$ Spurred by federal developments, provincial public sector workers' associations also began appealing for the creation of a provincial joint advisory council to serve as a consultative mechanism with management (White, 1985; Hodgetts, 1995). Three months after legislation was passed creating the NJC federally, on May 18, 1944 Ontario Premier Drew's government announced the formation of the Joint Advisory Council (JAC) to be made up of government and provincial representatives. ${ }^{18}$ Because municipal associations were "corporations" as such they continued to struggle for the right to organize and bargain collectively on behalf of the members, with quite uneven results (Frankel and Pratt, 1954).

The election of George Drew as Premier of Ontario in 1943 had somewhat moderated the extreme laissez-faireism of Mitchell Hepburn, boosted in good part by the emerging post-war expansion that was to engulf the province and the rest of the country. In 1943 the Ontario government implemented the Collective Bargaining Act and Rights of Labour Act which formally recognized the rights of unions to organize and bargain collectively, although the Acts were far from 'impartial' and marginally progressive since ultimate authority continued to reside at arms length from cabinet (Smith, 2009). The Acts covered most private sector and municipal workers, including some employees of crown corporations, agencies and boards but continued to formally exclude civil service workers proper.

As a result of the National War Labour Board's restrictions on wages and prices, and subsequent inflationary pressures, worker efforts to improve their working conditions and wages intensified. In 1944 there was a breakthrough. The federal government passed the Wartime Labour Relations Regulations, Privy Council (PC) order 1003 which "blew the lid-off labour-capital

\footnotetext{
${ }^{17}$ The NJC was created as a consultative body to discuss the "general principles" related to remuneration, promotion, tenure, transfer and other general conditions of employment. Crucially, however, the NJC was limited to a consultative role and was to remain a body strictly of an advisory nature.

${ }^{18}$ Unfortunately the JAC was scarcely a place for 'negotiations' as consultative meetings were rare and management continued to determine wages and working conditions unilaterally (Hodgetts, 1995).
} 
relations." (Palmer, 1985, p.192). For the first time PC 1003 legally recognized the rights of workers to organize and bargain collectively, led to the development of certification procedures, compulsory union recognition, defined unfair labour practices and established an administrative framework to enforce regulations. While the legislation extended to all private sector workers under federal jurisdiction, as well as public sector workers employed by crown agencies and boards one step removed from the provisions of the PSA and therefore organized under general or individual labour statues, civil service workers proper remained excluded from the legislation.

Under the auspices of the newly established PC 1003 on September 12, 1945 more than 10,000 Ford workers went on strike at Windsor, Ontario over increases in pay, workplace benefits, hours of work, promotion, tenure and efforts to establish a medical plan (Colling, 1995). Lasting more than three months, and resulting in a wave of cross-Canada sympathy strikes involving over 8,000 workers and 25 plants, the two sides agreed on December 16 to go to binding arbitration under the purview of Supreme Court Justice Ivan Rand. Six weeks later Justice Rand issued his landmark ruling. His decision provided for compulsory dues check-off for all employees in the bargaining unit whether they were members or not, since all workers in the workplace benefitted in some form from unionism. Moreover, what would come to be known as the 'Rand formula' prohibited all strikes during the term of a collective agreement and instituted a system of financial penalties, to be drawn from union dues, which would be levied against the union in the event of an illegal strike (Abella, 1973).

While Rand's pioneering decision would become one of the legal pillars upon which later labour legislation would be built, it was not without its contradictions (Fudge and Tucker, 2004). As valuable and significant as this decision was, it also implicitly depoliticized the trade union movement which increasingly came to rely on legal statues rather than a politically engaged and active membership to enact workplace changes. Increasingly, rank and file workers came to rely 
and depend on a series of professionals - from lawyers, strategists and officials - which increasingly disaggregated the collective capacities and consciousness of workers. These shortcomings aside for the moment, however, from 1941 to 1945 union membership nearly doubled from 362,223 to 711,117 (Lipton, 1973, p.266). Over a remarkably short period, Canada converted its facilities to meet the requirements of war and shortly thereafter reconverted them to meet the requirements of capital. As will be shown in the proceeding chapter, in the span of a decade Canadian labour was to make extensive strides in the areas of union recognition, compulsory dues and associated improvements in wages and working conditions. These gains were buoyed by additional breakthroughs in the provision of public services and social welfare provisioning. These gains were not, however, without their contradictions as the historical specificity of Keynesianism stunted the development of an alternative trade union and class project amidst the deceptive and conjunctural security of the postwar compromise.

\section{Conclusion}

This chapter has sought to provide a brief historical overview of the important socioeconomic and political transformations from the mid-nineteenth to mid-twentieth century. Over this time, the 'economic' or productive sphere which had once been sheltered from market forces was gradually eroded removing traditional rights and security over the means of subsistence. This process of commodification, whereby formerly self-subsistent workers were dispossessed of their land, labour and resources, necessitated the forceful creation of a market-dependent working class. As ownership and control over the means of production were centralized, backed by state sanctioned monopolies and legislative acts, workers increasingly sought to resist the dangerous, low-paying and laborious rhythms of capitalist forces by attempting to organize themselves into unions. However, buttressed by legislation reinforcing the power of economic and political elites, the capitalist classes aggressively resisted workers' attempts to unionize by blacklisting and 
dismissing sympathetic workers, non-payment of wages as well as deploying private militias and police forces as strikebreakers. As argued, there had always been a very close relationship between the state and capital. And it is in this regard that the development of a 'ruling class' can be understood as the embrace of private capital and the state essentially functioned as one to the detriment of the working class.

With the onset of the First World War, collective struggles over the right to organize and bargain collectively mushroomed. While important strides were made through the $1920 \mathrm{~s}$, labour was generally in retreat as the collective restrictions by the state and capital limited progressive labour reforms. While industrial unions continued to struggle over trade union recognition, public sector workers' associations distanced themselves from the broader labour movement and an association with working class politics, preferring to rely on the paternalism of management and cabinet. Through the first five years of the Great Depression there was little direct confrontation with capital or the state; however, by the late 1930s struggles at the G.M. plant in Oshawa and elsewhere had established industrial unionism as a promising form of working class organization. Public sector workers' associations, on the other hand, had progressed little beyond occasional appeals for greater input, but rarely backed their discontent with any genuine sign of militancy. While there were obvious exceptions, eruptions of public sector workplace militancy were few and far between.

With the onset of WWII, unemployment quickly dissipated and workers once again demanded recognition of trade union rights. At the same time, though, political fractures among social democratic and socialist trade unionists deepened working class divisions. Despite these cleavages, by the end of WWII the breakthrough legislation of PC 1003 and the Rand formula had institutionalized the right to organize and bargain collectively. While the former legislation recognized the rights of private sector unions and public sector workers under general labour 
relations statutes to organize and bargain collectively, and backed those rights up with legal and juridical protections, the later provided for compulsory dues check-off strengthening the financial base of worker organizations. Conversely, most public sector workers' associations did not experience as deep a breakthrough. For some, the pinnacle of their achievements lay in the introduction of joint advisory councils. However, discontent remained largely muted as their moderately superior pay and benefit packages fed a general sense of conservatism. Absent the collective bargaining rights enshrined in PC 1003 and the secure financial footing established as a result of the Rand ruling, many public sector associations continued to carry on their 'consultations' separately lacking the militancy and legal machinery recognizing their right to bargain collectively.

Also, while distancing themselves from the radicalism of trade unionists, a good many public sector workers, encouraged by their associations, preferred to curry favour with management rather than join in common cause with workers in other workplaces or regions. Such geographical dispersion coupled with a collective reluctance to voice discontent inhibited the expansion of unified objectives, while also stunting the development of a broader working class consciousness. As a result, representatives of the various public sector workers' associations often remained untrained in the art of negotiation, unlike many of their counterparts in the private sector whose experiences had been forged in active struggles. While the political consciousness of industrial unionists often stretched beyond the immediate concerns of their members, however impartial and limited, the same cannot be said of many public sector workers' associations whom were essentially premised on social and voluntaristic foundations ensconced in strictly legal as opposed to political struggles. Not only were public and private sector unions and associations separated by virtue of their location in the economy, but significant differences in their political histories, experiences and orientations worked to stunt their collective capacities. 
As a result of the unprecedented industrial upheavals and general civil disobedience begotten at the end of the Depression and war years, the state reluctantly began taking greater responsibility for social welfare provision, while seeking to 'mediate' a consensus between capital and labour. It is important to note, however, as will be discussed in the chapter that follows, that while the state cautiously began taking a greater responsibility for the provision of social welfare, including in some instances outright ownership in rail, public utilities and air transport, these Keynesian measures were never ends in themselves but means through which subordinate classes could be integrated all the while advancing capital accumulation. 


\section{Chapter 2 - Canada's Keynesian Compromise and the Transformation of Public Sector Trade Unionism: From Expansion to Impasse, 1946-1983}

This chapter begins with an overview of John Maynard Keynes's central theoretical premises. In contrast to the dominant political and economic policies predating WWII, I explore the ways in which Keynes' ideas promoted active fiscal and monetary policies, counter-cyclical budgeting and widespread public investments. I argue that while Keynes's ideas were progressive in comparison with his classical liberal counterparts, they nevertheless remained conservative at the core seeking to stabilize the capitalist system rather than alter it in any fundamental ways. Despite its limitations, I contend that the welfare state entrenched notions of shared collective responsibility and redistributive justice. However, while social services and programs rapidly expanded in the decades following WWII, by the mid-1970s the underlying foundation of the welfare state was coming under attack by emergent neoliberal economists and politicians as wasteful and unaffordable. Thus in order to understand the Keynesian welfare state and later neoliberalism, it is first necessary to begin with a discussion of Keynes important theoretical contributions.

From the late-1940s to mid-1970s, the Keynesian welfare state would undergo periods of expansion and contraction as labour, capital and the state struggled over the distribution of the social surplus product and social policy reforms. Given the deep recession of the mid-1970s, I argue that ruling elites set forth attacking union wages and benefits, progressive labour reforms and public services as part of broader efforts to reestablish their dominance and kick-start capital accumulation. In fact, Canada was a pathbreaker in deconstructing the welfare state and implementing neoliberal reforms. Indeed, one of the chief distinguishing features of neoliberalism in Canada is the extent to which state and capitalist class militancy actually led the charge against workers, working class standards of living and trade unions. This served as a political pretext leading to a sustained assault against what vestiges of Keynesianism remained in the midst of an emergent neoliberal counterrevolution. 
In exploring the intersections of social policies and labour reforms, I examine key legislative developments pertaining to trade unionism in the private and public sectors, drawing attention to the distinctive histories and trajectories which simultaneously expanded and constrained the right to strike and bargain collectively. As was argued in the previous chapter, virtually all public sector unions were geared toward understanding collective bargaining as a more or less legal process, rather than a political process. In this chapter I extend this analysis substantiating this observation historically and demonstrating that over the course of the 1970 s public sector unions have, to varying degrees, come to understand collective bargaining as an equally important political process. Despite this recognition, however, a good many public sector unions were unable to stop let alone reverse attacks against collective bargaining rights and demands for concessions. This raises important concerns about the structural limitations of unionization as an end in itself, which unions alone are powerless to overcome.

In what follows, I draw attention to the shifting relationship between capital, labour and the state over the Keynesian era, with an emphasis on changes to labour legislation. While workers covered under general labour relations statues were able to bargain collectively by the late-1940s, some public sector workers continued to be denied such rights until the 1960s and 1970s. Despite the extension of formal collective bargaining rights, I argue that consecutive amendments to the formal procedures governing the legitimate realm of trade union activities narrowed the scope of permissible militancy and entrenched a system of highly legalistic provisions which served to depoliticize the broader labour movement and working class politics as a whole. Moreover, just as many public sector workers were extended the right to bargain collectively, broader macroeconomic and political changes further constrained the scope of bargaining. For comparative purposes, developments in the public and private spheres are discussed simultaneously. Attention is drawn to the shifting composition of the labour movement, in particular due to rising numbers of 
women, higher-educated, racialized and younger workers, which brought once marginalized issues to the forefront of the labour movement. All things considered, despite the extension of collective bargaining rights and the expansion of public services over the three decades following WWII, I argue that by the 1980s labour appeared increasingly defeated amidst the erosion of the postwar class compromise.

\section{Keynes's 'Progressive' Liberalism}

As the political and economic instability wrought by the Great Depression, First and Second World Wars came to an end, the hegemony of classical economics was on the defensive. The alleged automaticity of the market as espoused by Smith, Ricardo and J.S. Mill proved increasingly incapable of adequately allocating resources, capital and labour, let alone providing a modicum of general social security. In particular, classical remedies such as those expounding the self-adjusting virtues of the free market were unable to deal with high levels of unemployment, increasing poverty and mounting social unrest. Thus it was becoming increasingly apparent, not only to policy makers and economists but to the general public at large that laissez-faire claims about the self-adjusting nature of the economy were failing to materialize. Instead, the anarchy of the market and cut-throat competition threatened to destroy capitalism. In light of the tidal waves of civil disobedience, political agitating by socialists, social democrats and other progressive forces, federal and provincial governments responded with a combination of social welfare and legislative measures designed to simultaneously quell social unrest and integrate (subordinately) broader masses of the working class. As a consequence, the classical liberal doctrine of minimal state intervention and Say's Law increasingly fell out of favour given the harsh realities experienced during the Great Depression. ${ }^{19}$ Moreover, the experiences of WWII demonstrated the immense organizational and

\footnotetext{
${ }^{19}$ Simply put, Say's Law argues that the aggregate income earned in the supply process (production) is equal to the cost of all that is produced. Therefore, exactly enough income is created to enable the population to buy everything that it has produced, and the economy will always remain at full employment. Moreover, adjustments in prices would
} 
administrative capabilities of the federal state, which came to play a central role in directing economic affairs, as well as intervening and 'mediating' political settlements between capital and labour. It was within this background and context that Keynes' ideas flourished.

Keynes' most well-known and influential work is his General Theory of Employment, Interest and Money (Keynes, 1936). Through the war effort the General Theory had an important influence on policy makers, politicians and economists of the day. While Keynes' ideas contrasted sharply with some of the theoretical starting points of his liberal counterparts, he was nevertheless a committed capitalist throughout his life who was convinced that the market was the best way of allocating resources, capital and labour. While Keynes accepted the orthodox classical view which argued that those who were unemployed had either priced themselves out of the market or were voluntarily or temporarily out of work, he argued that this explanation was not enough. Likewise, he was critical of the view that self-interest automatically translated into the public good. Rather, he posited that unemployment could also be a consequence of inadequate aggregate demand, while overt self-interest could lead to economic disequilibria. As a result, Keynes argued that governments needed to stimulate demand in order to reach full employment, which could be done through the use of active fiscal and monetary policy. This included, for example, direct government spending, stimulating private consumption or investment through tax cuts and subsidies, changes to interest rates as well as research and development grants to private entrepreneurs. While Keynes was critical of the laissez-faire approach, he did not reject the theory in its entirety but merely some of the underlying assumptions related to employment, interest and money (Milonakis and Fine, 2009; Hunt and Lautzenheiser, 2011).

Many classical economists did not concern themselves with the problem of unemployment. Part of the reason for this was because Say's Law, the idea that supply creates it own demand, made earned will automatically be spent on consumption (Hunt and Lautzenheiser, 2011). 
unemployment theoretically 'impossible' (Milonakis and Fine, 2009). While Keynes accepts the classical assumption that in the process of production the total output is equal to the total income, he rejected the notion that all income would automatically be injected back into the economy. Some income earned may be saved, spent on foreign produced goods or deducted through taxes. Keynes also rejected the notion that in a situation of full employment the rate of interest would automatically equate savings and investment, thus ensuring that aggregate demand and supply were equal. Instead, he held that the level of aggregate income was a far more important influence on the amount of savings than the interest rate (Keynes, 1936). Furthermore, Keynes argued that interest rates were influenced by the equalization of supply and demand of money, therefore concluding that savings and consumption were determined by income. ${ }^{20}$

Certainly interest rates mattered but Keynes rejected the classical determination of interest rates whereby savings and investment could be brought into balance by changes in the interest rate alone. Keynes argued that the classical theory provided a misleading view of how the economy reacted to increased savings. He argued that increases in savings do not set in motion changes in the interest rate which automatically preserves full employment. Instead, they could lead to falling demand, rising unemployment and declining incomes. For Keynes, excessive savings were a serious problem which could potentially lead to an economic downturn, since the total output was not being totally consumed. Thus for him unemployment was caused by a deficiency in overall demand because oversaving occurred as a result of the relative abundance of capital (Keynes, 1936).

For these reasons Keynes argued that it was demand, not supply, which determined economic growth. Rather than pushing to reduce wages in an effort to increase profits, since this

\footnotetext{
${ }^{20}$ As Hunt and Lautzenheiser (2011, p.411) explain: "In Keynes' view, a portion of the demand for money depended on expectations about what will happen to the interest rate in the future. When the interest rate was very high, very few people would expect it to go even higher in the future; consequently, very few people would hold cash for speculative purposes. At lower interest rates, more people would be inclined to believe that the interest rate would increase; consequently, more money would be held for speculative purposes by those who expected the interest rate to rise in the future. Therefore, the amount of money demanded for speculative purposes declined as the interest rate rose, and increased as the interest rate fell."
} 
would cause a problem of aggregate demand, he argued that without government efforts to increase expenditures unemployment could remain a persistent problem. As a consequence, Keynes rejected the laissez-faire approach which called for little, if any, government intervention. Instead, he argued that a certain amount of government stimulus needed to be built into the economic system if it were to temporarily solve the problem of unemployment (and thereby effective demand), even if this required deficit-spending. However, he also argued that budgets should be balanced over the business cycle, with surpluses in good years being used to offset deficits in bad years (Keynes, 1936). Keynes suggested that a recession could occur when the total demand for goods was insufficient, leading to an economic slump and losses of potential output due to unemployment. Thus he suggested that government fiscal and monetary policies could be used to boost aggregate demand, thereby increasing economic activity and in the process reducing unemployment and deflation (Heilbroner, 1999; Skidelski, 2009).

With the economy stuck in a significant depression throughout the 1930s, Keynes argued that government ought to concern itself with some central planning as well as seek to maintain high and stable levels of employment. These countercyclical fiscal policies, he argued, could dampen the severity of disequilibria in markets. ${ }^{21}$ In stepping in when savings exceeded investments, governments could increase their spending thereby reestablishing positive growth (i.e. the business cycle) and full employment. This initial stimulus then leads to other multiplier effects, a cascading series of economic investments whose total increase is larger than the original investment (Keynes, 1936; Skidelski, 2009).

Although Keynes rejected the alleged automaticity of the market, he generally believed in the allocative efficiency of market transactions backed by minimal government oversights and

\footnotetext{
21 These measures included monetary expansion (driving interest rates low), public investments (schools, parks, infrastructure), and state-led protection of industries vital to the national interest. This might also include tax measures to decrease income inequality and thus raise the tendency to consume, as well as state-led deficit spending in order to recapitalize markets.
} 
protective measures. Despite Keynes' 'progressive' liberalism he nevertheless maintained an ideological affinity to conservative economic doctrines. ${ }^{22}$ While Keynes was primarily concerned with ensuring that market competition did not undermine the general stability of capitalism as a whole, he was also concerned about the growing appeal of radical and Marxist/socialist-inspired political economy. ${ }^{23}$ Thus Keynes' ideas in and of themselves were hardly radical, let alone revolutionary. In fact, as the foregoing analysis has argued, the general thrust of his work was by and large conservative and in few ways critical of the inherently antagonistic relations between capital and labour, nor the coercive means by which the state secured capitalist domination. A more accurate, though still generous characterization would be to identify Keynes as a 'progressive' liberal seeking to ensure that social turmoil did not lead to a fundamental questioning of capitalist social relations. While Keynes' ideas remained hotly contested, both among supporters (Galbraith, 1958; Robinson, 1956) and Left and Right detractors (Hayek, 1944; Von Mises, 1944; Mattick, 1969; Schumpeter, 1942), they nevertheless played an important role in expanding the state's role in directing economic affairs and social services. Notwithstanding these important contributions, in what follows I argue that in the case of Canada these measures worked to extend commodification rather than shelter basic services from market imperatives. Furthermore, while Keynesian measures contributed to the extension of collective bargaining rights, in particular for public sector workers, they also entrenched a system of professionalized, complex and legalistic bargaining which implicitly depoliticized the labour movement.

\footnotetext{
${ }^{22}$ As one of Keynes' former students and intellectual expositors, John Kenneth Galbraith (1987, p.22) has argued, "the broad thrust of his efforts, like that of Roosevelt, was conservative; it was to help ensure that the system would survive. But such conservatism in the English-speaking countries does not appeal to the truly committed conservative...Better to accept the unemployment, idled plants, and mass despair of the Great Depression, with all the resulting damage to the reputation of the capitalist system, than to retreat on true principle."

${ }^{23}$ As economist Bruce Bartlett (2009) has written: “...the whole point of The General Theory was to knock away the Ricardian foundations of Marxism... And he [Keynes] had little respect for Marx, calling him "a poor thinker," and Das Kapital "an obsolete economic textbook, which I know to be not only scientifically erroneous but without interest or application for the modern world." See also Bartlett, 1984. I will return to Keynes's ideas and its relationship to social democracy more broadly in chapter 7 which, in light of the 2008 recession, have undergone a renaissance of sorts.
} 


\section{Canada's Keynesian Compromise: 1946-1962}

As argued in the previous chapter, during the 1940s both the Ontario and federal governments slowly began expanding social welfare provisions and extending collective bargaining rights. This included the universalization of pension, child welfare and unemployment insurance, for example, as well as the implementation of PC 1003 and the Rand formula which formalized collective bargaining rights. The arrival of what is conventionally called the welfare state was laid in the 1945 White Paper on Employment and Income, as well as Mackenzie King's Green Book proposals. ${ }^{24}$ The White Paper outlined the federal government's intention to implement Keynesian economic policies by maintaining high and stable levels of employment, counter-cyclical budgeting and a greater regulatory role over finance and industry (Campbell, 1987). Despite the administrative and constitutional separation of duties and responsibilities which hamstrung the provinces and federal state through the Depression years, over the next decade a number of shared-cost arrangements would be gradually introduced and expanded. While some of the provinces remained steadfastly opposed to such measures fearing the loss of sovereignty, such as Quebec and Ontario, the basis of Canada's Keynesian compromise was nevertheless established at the DominionProvincial conference in 1945 (McBride and Shields, 1997; Campbell, 1987; Wolfe, 1984).

It is my contention that in light of swelling union membership and massive demonstrations of civil disobedience, the postwar years led to a significant shift in the balance of class forces (McInnis, 2002; Panitch and Swartz, 2003; Heron, 2012). This social pact or Keynesian compromise, formed the basis from which the Canadian state expanded and developed its active and interventionist state policies, while laying the groundwork for the broader provision of social

\footnotetext{
${ }^{24}$ As argued, the move toward Keynesianism began slowly in the 1940s with the establishment of the Royal Commission on Dominion-Provincial Relations. Over the next five years at least 9 other studies were initiated outlining - in sometimes conflicting ways - an enhanced role for the state in the provision of social security. The most generous of these was the report by Leonard Marsh calling for income security, children's allowances, a national health policy and employment training. On the other hand, the most conservative, even reactionary, report was that by Charlotte Whitton who opposed automatic and universal programming fearing idleness and dependency on the state. For a full exposition of these competing reports see Hillyard-Little, 1998.
} 
services and expanded labour rights. ${ }^{25}$ Canada's experiment with Keynesian demand-side macroeconomic policy was guided by certain key commitments: an emphasis on high and stable levels of employment, active fiscal and monetary policy, major public works projects, progressive taxation, universal social programs, moderate capital controls and a basic commitment to domestic reinvestment (Wolfe, 1984; Skidelski, 2009).

However, these measures were never ends in themselves but means through which private enterprise could be stimulated while workers integrated into the logic of capital. While the scope of market penetration was somewhat constrained, for example in the realm of healthcare, public pensions and post-secondary education, these reforms actually embedded commoditification rather than, as has been argued, "decommodify" social services and labour (Esping-Anderson, 1990; Polanyi, 1944). Instead, such measures actually accelerated commodification through fullemployment policies and the expansion of services, which integrated and subordinated the working class to the imperatives of capital at precisely the moment when the long-term viability of the capitalist system was being questioned (Palmer, 1992; Panitch and Swartz, 2003). These short-term measures quietly consolidated capital's control over the labour process by legitimating the social subordination of the working class via impartial social welfare inducements as a patch onto the flawed fabric of the capitalist system.

As Lacher (1999) has argued, the partial decommodification of labour emerging in the context of the welfare state was linked to a widening and deepening of commodity relations which, taken together, integrated these seemingly contradictory processes. He shows how the historical dialectic of capitalism has oscillated between laissez-faireism and protectionism linking institutional

\footnotetext{
${ }^{25}$ Harvey $(2005$, p. 10$)$ describes the period thus: "States actively intervened in industrial policy and moved to set standards for the social wage by constructing a variety of welfare systems (health care, education and the like)...market processes and entrepreneurial and corporate activities were surrounded by a web of social and political constraints and a regulatory environment that sometimes restrained but in other instances led the way in economic and industrial strategy. State-led planning and in some instances ownership of key sectors (coal, steel, automobiles) were not uncommon."
} 
structures together to the totality of capitalism. Thus, the Keynesian period served as an incubator providing the ideological, political and economic stability necessary for capitalist expansion on an ever-increasing plane. ${ }^{26}$ This served to win over a larger segment of the working class to the rhythms of capitalist production so as to preserve and extend the scope of capitalist class power.

This argument is demonstrated through an examination of two federal programs which were central to the development of Canada's welfare state. The first, Unemployment Insurance (UI) in 1940 , established a minimum level of workplace financial insurance in the event of layoffs or an economic downturn. Although UI was an important gain fought for and won by workers, it did not at all end their relationship to capital as commodified sellers of their labour power: to get this income workers still had to participate in paid employment, only received UI temporarily, and payments remained low enough so as to induce people to return to work. Moreover, insofar as UI gave workers the option of waiting for an appropriate job rather than taking a job they might soon quit, it also increased job stability and actually improved the workings of labour markets in the context of the relatively tighter labour markets of the time. Second, universal family allowances introduced in 1944 sought to maintain the value of family purchasing power in the event of inflationary pressures or employment losses, while ensuring the general well-being of Canadian families. Like UI, family allowances embedded the process of material reproduction through the market by supplementing the social reproduction of labour in an effort to stabilize the social conditions which sustain capital and labour's unequal power relations.

\footnotetext{
${ }^{26}$ In Lacher's (1999, p.350) words: "The limited 'decommodification' of the labour of individuals through rights of citizenship and transfer incomes which made the 'fit' between mass production and mass consumption possible was bound to the further commodification of the realm of the 'social' itself.".
} 
Paralleling developments federally, and in an attempt to stave off the growing popularity of the CCF in Ontario, Conservative Premier George Drew also cautiously moved forward with expanded social services. ${ }^{27}$ Drew's Twenty-Two point program expanded medical and dental care, access to elementary and secondary school, improved old-age pension rates, increased the regulation of farming and natural resources, and began a series of public works projects (HillyardLittle, 1998; Struthers, 1994). These initiatives were central to expanding the scope of finance, manufacturing and construction industries, which boosted accumulation though increased social and job security. Equally important, these partial social inducements (re)legitimized the capitalist system in light of the Depression years, particularly as a result of the growing appeal of socialist politics and the emerging Cold War.

With the election of St Laurent as Prime Minister in 1948 and Leslie Frost as Premier of Ontario in 1949, both spheres of government initiated and expanded social welfare provisioning. However, conflicting constitutional and administrative responsibilities through the 1940s continued to bedevil inter-governmental relations. ${ }^{28}$ However, in the years following the war, where power gradually returned to the provinces, concerns over spillover and outright intrusion increasingly took centre stage. ${ }^{29}$ What followed was a slow but steady integration of shared-cost programming and political compromises which resulted in the simultaneous devolution of powers to the provinces, yet with significant federal oversight and influence. Despite the authors' of confederation's quest for a

\footnotetext{
${ }^{27}$ Having won a minority government in 1943, the conservatives moved quickly to stave off the growing appeal of the CCF who had for the first time become the official opposition in Ontario (Azoulay, 2000). However, by 1951 the CCF was reduced to just 2 seats ushering in a decade of rebuilding, rebranding and political realignment reemerging in 1961 in the form of the New Democratic Party (NDP). See Azoulay, 2000; Whitehorn, 1992.

${ }^{28}$ As Inwood (2001, p.126) has argued: "When we look at the original constitution, it is quite apparent that the Fathers of Confederation quite consciously developed a system whereby the federal level of government would have certain powers to intrude on provincial jurisdiction and in which the federal government was clearly intended to be the more powerful of the two levels." (Inwood, 2001, p.126).

${ }^{29}$ A significant part of this was a consequence of the makeup of the Canadian constitution. For instance, the provinces (excluding the territories) were granted responsibility for social welfare, health and education, and jurisdiction over natural resources and employment standards legislation. On the other hand, the federal government oversaw concerns related to the national interest, equal treatment and opportunity, equalization payments, international trade (which brought resources under federal jurisdiction) and Aboriginal concerns, although maintained control over the predominant powers of taxation (Clement and Williams, 1989; Stevenson, 2009).
} 
strong centralized federal state, what emerged over the quarter-century following WWII was an increasingly decentralized federation (McBride and Shields, 1997; Inwood, 2001; Stevenson, 2009).

Despite ongoing constitutional tensions, the quarter-century following WWII resulted in the expansion of shared-cost programming between the two levels of government, the development of a system of national standards and the entrenchment of basic social minimums. This era would come to be known as one of "cooperative federalism" and was largely the result of three interrelated reasons:

"First, the Great Depression of the 1930s gradually illustrated the inherent flaws of the original federal bargain, which had assigned most powers to raise revenue to the federal government, while giving most jurisdictional authority to the provinces. Second, the necessity to prosecute the war effort during WWII meant that power accrued to the national government, which it was reluctant to give back after the war had ended. Third, postwar reconstruction and the massive expansion of the social-welfare state from the 1940s onward apparently required the guiding hand of a strong central government." (Inwood, 2001, p.128).

The postwar boom through the late-1940s and 1950s led to the gradual expansion of family allowances, pensions, affordable housing and in 1956 the introduction of equalization transfers designed to stimulate public works and infrastructure projects such as the Trans-Canada Highway (1949) and St Lawrence Seaway (1954), which were central to expanding the scope of trade and investment. Likewise, in Ontario the provincial government began consolidating the planning and administration of health and education, infrastructure, incarceration and public works and utilities projects, which had formerly been the responsibility of municipalities. Premier Frost implemented Ontario's first tax on corporations, succession taxes, liquor and gas taxes, and new investments in affordable housing (Rea, 1985). During this time the country as a whole would experience the greatest growth in its history, ingraining a general sense of redistributive justice and basic principles of collective social responsibility (Hillyard-Little, 1998).

As a result of massive mobilizations on the part of women's and immigrant groups, as well as labour and socialist activists, the scope of 'legitimate' public demands had been gradually expanded. Central to the extended recognition of collective social responsibility were militant job 
actions in the manufacturing and resource industries. For instance, in 1946-47 over 220,000 workers in logging, mining, meatpacking, shipping, auto, steel, rubber, textiles and electrical production walked-out over the right to strike, bargain collectively, improve wages and working conditions, which resulted in over 7 million lost days of production (Palmer, 2003). In light of mounting civil disobedience, in 1948 the federal government introduced the Industrial Relations Disputes Investigations Act (IRDIA), which cemented the legislative rights first established with PC 1003 for employees under federal jurisdiction.

With the establishment of the IRDIA, collective bargaining rights were extended to a limited number of public corporations and agencies (i.e. the broader public sector), while civil servants proper remained excluded from collective bargaining rights. ${ }^{30}$ In the 1950 s, with the economy expanding and unemployment low, public sector pay lagged behind their private sector counterparts (Hodgetts, 1973). As the decade progressed some associations, such as the Civil Service Association of Ottawa, were becoming increasingly restless under the limited parameters of the NJC. In 1953, the federal government finally agreed to a voluntary, revocable dues check-off which strengthened the associations' ability to fund educational and research initiatives and hire full-time staff persons. However, the government continued to determine wages and working conditions unilaterally and with little input from the CSC (Arthurs, 1971). Moreover, the government refused to recognize the rights of various associations to speak on behalf of their members or implement formal measures recognizing workers' freedom to join and participate in such associations.

On the whole, the 1950 s was generally a period of little direct confrontation between the various public sector staff associations and their employer, the government. In fact, internal disputes began to arise among some associations over the slow pace of workplace changes, pay increases

\footnotetext{
${ }^{30}$ As A.H. Brown, then-Department of Labour solicitor argued, 'The business of government must go on without interruption, legislation which affords to employees recognition of the right to strike is not appropriate or consistent with the requirements or necessities of government administration.' (cited in McInnis, 2002, p.169-70).
} 
and differing conceptions of 'appropriate' civil service association. In 1954 the Civil Service Association of Ottawa withdrew from the CSF and merged with the more militant Amalgamated Civil Servants of Canada. As discussed in the previous chapter, this intensified tensions among the CSF who wanted to maintain a loose confederacy of associations, and the Amalgamated who sought to organize across departmental lines and workplaces (Hodgetts, 1973). Conflicts over the appropriate means of dispute resolution - the CSF favouring the NJC and Amalgamated pushing for collective bargaining rights backed with binding arbitration (absent the right to strike) - continued to bedevil their unification. In a vain attempt to demonstrate some willingness on the part of government to concede more space for collective bargaining for those not covered by general labour or individual statutes, in 1960 the Civil Service Act was reformed for the first time in 40 years. The highlight of the reform was a statute requiring that the government consult "from time to time" with the representatives of the various associations, as well as the CSC over the determination of wages (Hodgetts, 1973). Binding arbitration, let alone the strike option however, continued to be viewed as an inappropriate measure for dispute resolution in the event of an impasse citing the ultimate sovereignty of government.

Similar in kind to the passing of the IRDIA, in 1948 the Ontario government passed the Ontario Labour Relations Act (OLRA) which extended the right to strike and bargain collectively for workers in the private sector as well as state agencies and corporations, including those at the municipal sphere. ${ }^{31}$ The OLRA established Ontario's first independent labour relations board, which was given the power to certify and decertify unions as well as remedial powers of reinstatement. Moreover, the OLRA established new procedures for certification, mandated bargaining in good faith, prohibited strikes and lockouts during the terms of a collective agreement,

\footnotetext{
${ }^{31}$ Because municipal "corporations", as they are formally called, were never regarded as sovereign political entities they were creatures of the provinces subject to the rights and powers conferred to them by the province. As such, municipal labour relations in the main fell under general, or private sector, labour relations statutes (Arthurs, 1971).
} 
defined unfair labour practices and established new conciliation protocols (Smith, 2009). While the legislation mirrored many of the protocols established in the IRDIA, mandatory automatic dues check-off was still three decades away. Ontario civil servants proper, however, continued to be denied the right to organize and bargain collectively. ${ }^{32}$ With the lifting of wage and price controls in 1946 , inflation rose sharply through the decade leading to deteriorating wages for public sector workers.

In British Columbia, Saskatchewan and Alberta, many public sector workers' associations 'affiliated with the Trades and Labour Congress and have championed the cause of the organized labour movement...[holding] firmly to the view, though sometimes against strong internal opposition, that organized labour deserves support and that the hand of the association is strengthened if it can claim backing from other provincial groups' (Scarrow, 1957, p.66). In spite of these exceptions, most Ontario provincial public sector workers' associations remained unaffiliated and moderate in their expectations through the 1950s. But this would change by the end of the decade. This occurred for three main reasons and is related to industrial militancy as well.

First, through the 1960s public sectors workers' pay and working conditions continued to lag behind their private sector equivalents (Arthurs, 1971; Briskin and McDermitt, 1993). In conjunction with formal limitations on collective bargaining rights and little movement from the government over previous decades, these immediate workplace and standards of living concerns mobilized large cohorts of the public sector around these issues. This was related to, second, an important demographic shift in the makeup of public sector personnel. From those ensconced in the

\footnotetext{
${ }^{32}$ Through the 1950s the JAC was virtually extinguished as a means of useful consultations: "It might be argued that the council's have precipitated more problems than they have solved; that because suggestions for their improvement have been rejected by the government, employer-employee relations have actually deteriorated." (Scarrow, 1957, p.72). The complaints, like those of the CSF federally, revolved around the fact that the JAC lacked substantive authority, was limited to infrequent meetings, and was dependent upon the good will of cabinet for the granting of pay increases or entertainment of grievances. After more than a decade of ineffectiveness, and as result of management's insistence on dealing with grievance matters on a case-by-case basis, by 1955 the CSAO was openly expressing little confidence in the JAC. Given the slow pace of formal negotiating rights, the CSAO gradually embraced a more formalized and confrontational approach to collective bargaining (Hodgetts, 1995; Roberts, 1994).
} 
workplace habits, forms and experiences of the Depression and WWII years, the significant growth in new public sector personnel in the 1960s resulted in a generational shift whereby large cohorts of workers were younger, largely female and college or university educated (Hodgetts, 1973; Briskin and McDermott, 1993; Briskin, 2007). Accordingly, paternalistic relations with management were gradually eroded as second-wave feminism expanded expectations and rank and file workers began asserting themselves against the traditional conservatism of union officials and management. Third, as a result of the significant growth brought about by the extension of the welfare state, including in some instances militancy in the federal public sector (e.g. postal workers), municipally (e.g. utilities) and by public sector workers in others provinces (e.g. teachers), many Ontario public sector workers gradually became more receptive to militant and confrontational job actions (Scarrow, 1957).

Moreover, as the province of Ontario assumed greater responsibility for services formerly provided by the municipalities, the scope of departments, crown agencies and boards gradually expanded. While some workers continued to remain excluded from organizing based on the prohibitions of the PSA, others in the rapidly expanding healthcare and education sectors waged important struggles over the right to organize and bargain collectively (Frankel and Pratt, 1954; Palmer, 1992).$^{33}$ A fourth reason might be added. As these opportunities grew through the 1960 s, the emergence of what was to become the Canadian Union of Public Employees (CUPE) on the provincial scene pushed many provincial public sector workers' associations toward more militant and radical job actions. ${ }^{34}$ In tying workplace issues to broader political objectives, CUPE's

\footnotetext{
${ }^{33}$ Once workers were transferred to public sector agencies and boards one step removed from the provisions of the PSA, this meant that other unions were free to organize the workers based on the first come, first served rules of the OLRA.

34 As Ross (2005, p.281) has argued, CUPE's predecessors, NUPGE and NUPE, "were primarily the products of male, blue-collar, skilled and unskilled workers in the hydro-electric and municipal sectors, whose workplaces came into existence at the turn of the last century, and whose union locals were forged during the unionization and strike wave associated with the First World War." (Ross, 2005, p.87). At the time of its formation, the CUPE represented over 78,000 members across 483 locals. See Ross, 2005 for an thorough examination of CUPE's formation.
} 
forebears had a long history of organizing municipally across departments, sectors, occupational categories and regions. NUPSE, for example, had long been affiliated with the CCL, while NUPE was affiliated to the TLC (Ross, 2005). Increasingly, CUPE began lobbying for the extension of full collective bargaining rights (binding arbitration backed by the right to strike) for all public sector workers, including the civil service proper. While covering the vast majority of municipal public workers, CUPE also began to make important inroads into the provincial sphere organizing workers at the Workmen's Compensation Board, Liquor Control Board of Ontario and Ontario Housing Corporation. Similarly, in an effort to broaden its base, the CSAO began expanding its membership beyond those covered by the provisions of the PSA and into those covered by general or individual labour statues such as the University of Guelph, Niagara Parks Commission and healthcare sector (Roberts, 1994).

Recognizing the limitations of a splintered labour front, in 1956 the CCL and the TLC merged to form the Canadian Labour Congress (CLC), although many public sector associations remained unaffiliated (Heron, 2012). Yet the merger was not accompanied by the unification of a broad coalition of progressive forces. Rather, the divisions amongst socialists, social democrats and other progressives grew sharper as anti-communist propaganda, post-war economic growth and distrust among competing unions inhibited the formation of a unified labour front. ${ }^{35}$ Despite the fractures, major strike actions through the 1950 s involving nearly 22,000 workers at Ford, Massey Harris, Inco, Falconbridge, G.M. and de Havilland Aircraft over wages, benefits and grievance procedures brought the province of Ontario to a near standstill (Yates, 1993; Clement, 1981; Palmer, 1985; Gindin, 1995). Given the large influx of women partaking in paid-employment over

\footnotetext{
${ }^{35}$ As McInnis (2002, p.179) notes: "In terms of industrial-relations policy, the Cold War battles of the late-1940s served to isolate and weaken communist unions - the organizations that had long advocated a sense of working-class collectivity. This sense of collectivity gave way to the resurgent individualism expounded by mainstream unionism. The expulsion of left-wing unions in Canada left the role of leadership to the pragmatic, responsible men who never intended to challenge the system under which they operated. Cold war politics served to narrow greatly the range of dialogue for social reform."
} 
the decade following WWII both Ontario and the federal government instituted equal pay for equal work legislation prohibiting wage discrimination on the basis of sex (Thomas, 2009). While a first step, this did little to stem ongoing workplace inequities related to discrimination in hiring, unfair promotion, pay determination, sexual harassment, health and safety, as well as maternity leave and child care concerns. Over the next decade unemployment in Ontario hovered around 2 percent, slightly lower than the Canadian average. As a consequence of a burgeoning economy and worker militancy, union density rose from 13 percent in 1941 to 23 percent in 1949 and nearly 33 percent by 1957 (Smith, 2009)

The election of PM Diefenbaker in 1957 led to the expansion of old-age pension and postsecondary education as the federal government's Technical and Vocational Training Assistance Act (1960) split seventy-five to twenty-five percent the ratio of federal to provincial funding (Stamp, 1982). As a result of ongoing industrial tensions, in 1957 the government of Ontario established the Select Committee on Labour Relations to explore expanding the collective bargaining rights of trade unions (Smith, 2009). Three years later, based on the Select Committee's recommendations, the OLRA was once again amended. While most of the amendments were of a technical nature dealing with certification procedures, conciliation and arbitration methods, additional changes included the weakening of certification minimums and restrictions on striking, and the refusal to include voluntary revocable dues check-off. Furthermore, under changes to the Judicature Act the scope for granting injunctions was expanded curtailing picketing and strike activity during a labour dispute.

These changes resulted in a far more legally circumscribed collective bargaining process, which increased the technical and specialized demand for highly trained legal and research experts. This served to confine trade unionism to the exceedingly narrow confines of contract law, while delimiting the broader politicization of the labour movement. In the span of scarcely two decades, 
collective bargaining and trade unionism had been transformed from being prohibited to entrenched in legal provisions and institutionalized procedures governing legitimate practices. While contributing to the professionalization of trade union specialists and experts, this had the additional effect of removing the ideological and political aspects of trade unionism from the realm of collective bargaining. In other words, the political character of trade unionism was stripped from the capitalist context in which it was embedded, thereby weakening rank and file input into the deliberative process and disconnecting broader issues related to social justice and democratic reforms. The short recession of the early 1960 s temporarily arrested the expansion of the welfare state as the governing conservatives - reverting to classical remedies - sought to cut corporate and income taxes, and roll-back the scope of government intervention into the economy. Given the economic downturn, these measures coincided with a crisis of political fortunes for the federal Conservatives and an ensuing national election

\section{From Expansion to Impasse: $1963-1983$}

In 1963, the Liberals were returned to power establishing Lester B. Pearson as Prime Minister. Boosted by a renewed bout of economic growth in the mid-1960s, including significant mobilizational efforts by trade unionists and social justice activists, Pearson's Liberals resumed the expansion of the welfare state temporarily halted by their Conservative predecessors. During this time the Liberals introduced three pieces of legislation that entrenched the welfare state. The first, the Canadian Pension Plan (CPP) in 1965 established a national compulsory contributory pension plan. Second, the Medical Care Act in 1966 established a national system of personal health insurance. And third, the Canada Assistance Plan in 1968 consolidated shared-cost program financing for a range of services such as health care, education, social assistance, services for the elderly and disability allowances. To the programs outlined above were added the Guaranteed Income Supplement for low-income seniors, the lowering of pension eligibility from 70 to 65 and 
amendments to the National Housing Act which provided loans to provinces for public housing (Campbell, 1987; Wolfe, 1984).

The Pearson government also introduced legislation enacting the 40-hour work-week, two weeks vacation and a new minimum wage for workers under federal jurisdiction. Likewise, the Liberals also replaced Canada's overtly prejudicial immigration process with a points-based system, and established the Royal Commission on the Status of Women (Morris, 1982; Whitaker, 1991; Sangster, 2010). Like their counterparts in Ottawa, Premier Robarts' Liberals in Ontario were also expanding universal social programs and government enterprises. In 1968, Premier Robarts finally gave in to public pressures, particularly from trade union and social justice activists, to fully adopt a public health insurance system with the establishment of the Ontario Health Insurance Plan (OHIP), and in 1969, implemented the province's first provincial income tax on top of the federal income tax. Indicative of the growing influence and scope of government services and responsibilities, Ontario's total budget had grown from less than $\$ 1$ billion in 1961 to over $\$ 5$ billion ten years later (Rea, 1985; MacDermid and Albo, 2001).

By the early-1960s the CSF had come around to demanding formal negotiating mechanisms backed by binding arbitration. ${ }^{36}$ But as a result of their unwillingness to back the strike option for all public sector workers, this led the postal workers' union to officially withdraw from the CSF (Palmer, 1992; White, 1990). In seeking to expand the scope of negotiations, in 1963 the CSF circulated to all major party leaders a request for their views on collective bargaining rights for public sector workers. In light of continued agitating by the CSF, broader public sector unions, in particular letter carriers and mounting pressures from private sector trade unionists, all party leaders responded favourably to collective bargaining rights for public sector workers (Hodgetts et al,

\footnotetext{
${ }^{36}$ The CSF, however, continued to formally distance themselves from the broader labour movement and the Canadian Labour Congress in particular. While this was in part due to ongoing concerns over direct affiliation with 'radical' industrial unions, in fairness the various associations which made up the CSF were also concerned about direct affiliation with the NDP since they were to formally maintain a strict non-partisanship (Hodgetts, 1973).
} 
1972). In 1963, the Pearson government appointed the Preparatory Committee on Collective Bargaining in the Public Service. After two years of consultations with deputy ministers, government representatives, business groups, public sector workers' associations and representatives of industrial unions, the Committee drafted suggestions outlining a complete system of collective bargaining rights for all federal employees not falling within the scope of general labour relations statues. Shortly after the release of draft recommendations which called for binding arbitration as the ideal means for dispute resolution in the event of an impasse (without the right to strike), the extralegal 1965 postal workers' strike rendered this option obsolete, drastically transforming the attitudes of many of the associations and management (White, 1990; Parrot, 2005; Palmer, 1992).

The postal workers' strike was the largest since the end of WWII involving 23,000 workers. Arthurs (1971) considers the strike to be a clear victory as it received widespread public sympathy, improvements in wages and working conditions, and was backed strongly by private sector unions and significant quarters of the mainstream press. This struggle also brought issues related to sexual harassment, maternity leave, equal pay for work of equal value, promotion and tenure, for example, to the limelight as women increasingly asserted themselves in the union, workplace and abroad (White, 1990; Briskin and McDermitt, 1993). Just as the 1937 Oshawa strike at GM cemented industrial unionism, it would not be a stretch to suggest that the 1965 postal workers' strike laid the groundwork for the institutionalization of public sector unionism.

Given the potential for enhanced collective bargaining rights, in November 1966 the CSF (80,000 members) and the Civil Service Association of Canada (successor to the Amalgamated, 25,000 members) came together to form the Public Service Alliance of Canada (PSAC). Warskett (1997, p.149) characterizes the formation of the PSAC as one of "reluctant unionism." She writes (p.152): "The intention of the founders of the PSAC was not to create a trade union, an industrial 
union, or even a white collar union but, rather, an 'organic unity among all civil staff association."' In contrast to Warskett (1997), in a much earlier study Lemelin (1978, p.119) argued: "The Alliance's attitude is basically one of peaceful coexistence. It is founded on the conviction that rank and file members can get more through working in harmony than confrontation. Underlying their attitude is the belief that strikes would bring more harm than good or that, in many circumstances, strikes would not increase union bargaining power. Also, perhaps a natural inclination toward cooperation rather than confrontation prevails in most of the PSAC leaders. As a consequence the Alliance is characterizes by an absence of militant speeches or aggressive newspapers which might provide the impetus for militant action." However, by the 1970s such perceptions of PSAC workers (and largely female, public sector unions more generally) as passive and docile had become obsolete.

The merger resulted in PSAC becoming the largest union in the federal public sector with workers in all provinces and territories, and covered by both general and individual labour statutes. After years of agitating by private and public sector workers, and just four months after the creation of PSAC, a new era of labour-management relations was enacted with the passing of the Public Service Staff Relations Act (PSSRA) in $1967 .^{37}$ The PSSRA, together with the Public Service Employment Act (PSEA) and an amended Financial Administration Act, brought labour relations in the public sector in the main with their private sector counterparts. The PSSRA established a system of collective bargaining rights which included exclusive representative rights for bargaining units, prohibitions on unfair labour practices, obligations to bargain in good faith, binding arbitration

37 The introduction of the PSSRA was modeled on legislation allowing public sector workers to unionize in Saskatchewan (1944) and Quebec (1965) (Palmer, 1992). 
backed by the right to strike and a legally enforceable collective agreement oversaw by the Public Service Staff Relations Board (Arthurs, 1971; Palmer, 1992; White, 1990). ${ }^{38}$

This made more clear the division of labour between management and employees, which meant excluding some managers and government representatives from unionization. However, the PSSRA also constrained the scope of the legislation by preventing those workers deemed essential in the "interest of safety or security of the public" from striking (Hodgetts, 1973, p.337). By this time, the majority of the federal public sector had become unionized, two-thirds of which (or 133,000 employees) were covered by various PSAC locals (Warskett, 1997). The Professional Institute of the Public Service of Canada, founded in 1919, had grown to represent over 13,000 workers while the Council of Postal Workers, one of the forerunners to the Canadian Union of Postal Workers (CUPW), represented over 27,000 workers. These three unions represented over 85 percent of the federal public sector, with the remaining 15 percent (or about 24,000 workers) organized by various other unions (Arthurs, 1971). By this point, total public sector employment had grown from just 9 percent in 1946 to 25 percent of total employment by 1965 (Rinehart, 2006).

In light of increasing militancy in the public sector, as well as ongoing labour strife in the mining, auto and steel industries, in 1967 the Robarts government established a special advisory committee on Collective Bargaining in the Ontario Government Service headed by Judge Walter Little. With the CSAO, CUPE and other labour associations pushing for the expansion of collective bargaining rights, the government requested that Judge Little examine the appropriate scope of bargaining units, forms of negotiations and methods for resolving disputes. In short, Judge Little's report recommended giving the CSAO representation rights for the entire civil service, excluding

\footnotetext{
${ }^{38}$ As discussed above, the PSSRA applied to all employees in the public service of Canada located in the central administration or one of its autonomous agencies. Within the central administration, that is, direct public service, the Treasury Board bargains on behalf of the government, while the separate agencies either conduct their own negotiations or delegate this function to the Treasury. However, it is important to reiterate that some Crown corporations, such as Atomic Energy of Canada, the Canadian National Railway, and Air Canada, continued to bargain under general or individual labour statues, rather than under the special public sector provisions (Hodgetts et al, 1972; Arthurs, 1971).
} 
management and professionals from the scope of bargaining, and resting ultimate authority with management over the determination of merit, job classification and pay (Little, 1969). While Judge Little believed that the right to strike and lockouts were appropriate in the private sector, he argued that it was inappropriate for public sector workers citing the ultimate sovereignty of government and the fact that the public was owed the right to uninterrupted public services. Soon after Little released his report, the government appointed the Committee on Government Productivity (COGP, 1969-1974) . Made up of business executives and private consulting firms, the Committee did not have a single woman, person of colour, unionist or politician among them. For Roberts (1994), the 10 reports published by the Committee between 1969 and 1974 were the precursors to neoliberalism in Ontario. The reports sought to introduce "best business practices" into the public service, increase government productivity and eliminate waste and inefficiency. Moreover, in an effort to shed 'liabilities', the committee suggested a wide-range of opportunities for privatizing and contracting-out services and government enterprises (COGP, 1969-1974). The endorsement of the Little Report and Committee on Government Productivity Reports by the Ontario Tories marked a turning point in the relationship between government and many public sector workers' associations from one of paternalism to a more formalized and confrontational employer-employee relationship.

During the tenure of both Pearson and Robarts, the accelerated pace of corporate mergers and acquisitions left the Canadian economy more concentrated than ever in manufacturing, transport, utilities, finance, trade and mining (Clement, 1975; Carroll, 1986). The corporate concentration of power through the late-1960s resulted in a period of major industrial conflict and working class unrest. For instance, in 1969238 disputes involving more than 130,000 workers and over 5 million working days lost galvanized the province of Ontario (Smith, 2009, p.359). With job losses mounting, a new Canadian nationalism increasingly came to play an important role in 
mobilizing workers against the erosion of the Standard Employment Relationship (SER). ${ }^{39}$ As a result of its large manufacturing and resource sectors, the new nationalism was particularly concentrated in the Ontario region and was premised on fears of American absorption (Grant, 2000; Gordon, 1966; Laxer, 1975). Citing the growing proportion of foreign direct investment by American firms, increased plant closures and cultural homogenization, suspicions of US imperialism became an important political rallying point for workers across the province and country (Azzi, 1999; Levitt, 2002; Laxer, 1973). ${ }^{40}$ "Far from being a tool employed exclusively by Canada's economic and political elites, the new nationalism became a powerful rhetorical weapon in the hands of working people to be used against companies that closed plants." (High, 2003, p.169).

As the 1970s wore on, however, the Keynesian welfare state in Canada experienced periods of expansion and contraction owing to fluctuating economic conditions. For example, while UI was extended to include a greater proportion of those unemployed in regions across Canada, new entrance requirements toward the end of the decade eroded many of the earlier gains. In 1977 the Established Programs Financing (EPF) framework consolidated healthcare and post-secondary education funding, however due to real reductions of tax points and direct cash transfers the net result was a decrease in actual funding. As such, "By the mid-1970s neoliberals were arguing that government was too large, deficits were unacceptable, the tax system in need of reform, and spending priorities in need of reallocation." (McBride and Shields, 1997, p.54). As economic

\footnotetext{
${ }^{39}$ Briefly, the SER refers to a work arrangement based on a single employer, full-time, year-round employment, often under direct supervision with benefits and expectations of indefinite employment (Vosko, 2006, 2007; Duffy et al, 1997; Shalla, 2007). The SER was premised upon the white male breadwinner/family wage model, whereby women's employment was understood to be secondary to men's higher-paying and secure jobs. Of course, significant exclusions along the lines of race, gender, sexuality and ethnicity excluded many from the benefits of stable employment resulting in the quite uneven and impartial extension of the SER (Teelucksingh and Galabuzi, 2005; Bezanson and Luxton, 2006; Das Gupta, 1996).

${ }^{40}$ For example, in response to the closing of Dunlop tire in 1970, "the Globe and Mail contended that the Ontario government has a duty to respond to the Dunlop shutdown. By claiming that companies should demonstrate to the public that the closing was unavoidable, the editors revealed they did not believe in the inevitability of industrial decline." (High, 2003, p.174).
} 
conditions worsened, Canada became a pathbreaker in restructuring the state and implementing neoliberal reforms. While the Keynesian era had resulted in workers gaining a larger share of productivity growth as a result of the postwar class compromise, such a political concession had become a barrier to extracting larger portions of the social surplus product.

Wage militancy by trade unionists contributed to reduced profit margins, higher standards of living meant growing expectations and affordable public services demonstrated - problematically for the private sector - the viability of a public sector alternative. In short, a narrowing of the income and wealth gap had become a political and economic liability to capital as the balance of class forces tilted - albeit in an impartial and uneven manner - too far in the direction of labour. The rejection of Keynesianism was also due to external factors as a result of increased international competition and institutional restructuring. ${ }^{41}$ Critics of neoliberalism often recognize the U.S. or Britain (Harvey, 2005; Workman, 2009) and in some cases Chile (Connell, 2010) as blueprints or prototypes of neoliberalism. From Reagan's monetarist shock therapy (1979) and firing of unionized air traffic controllers (1981) to Thatcher's confrontations with miners (1984) and sell-off of state assets (1980), including General Pinochet's own massive liquidation of public assets and resources (1973), all are often cited as watershed moments in the history of neoliberalism. What is often underappreciated, however, are the combined efforts by federal and provincial governments in Canada which predated or anticipated many of these flashpoints of restructuring. In fact, as I show below, this is one of the chief distinguishing features of neoliberalism in Canada.

The specificity of Canada lies in its integration with the dominant capitalist country to the south, while having a relatively stronger labour movement in terms of union density and a social

\footnotetext{
${ }^{41}$ This includes the rebuilding of Europe's and Japan's productive capacities, the end of the gold standard in 1971, the 1973 Arab oil embargo, the Iranian Revolution and subsequent quadrupling of oil prices, capital flight to newly emerging industrial regions with cheaper pools of labour and lower environmental standards, as well as technological and organizational restructuring in the manufacturing heartlands of Canada (Workman, 2009; Burke et al, 2000; Harvey, 2005; Peck, 2010; Panitch and Gindin, 2012).
} 
democratic party in the form of the NDP. This created pressures to actually get ahead of the curve as the Canadian state undertook measures to ensure that enterprises remained competitive in U.S. and international markets. Because of the U.S.'s capacity to manipulate the dollar price (the global reserve currency) and to exploit Wall Street's international financial dominance, this structural/institutional power meant avoiding what other states had to do (Gowan, 1999; Panitch and Gindin, 2012). In the case of Canada, this meant using the whip of state power to accelerate capitalist restructuring. This included adjusting the domestic economy to ensure high levels of domestic savings and investments, ensuring balance of payments, maintaining public and private indebtedness and ensuring a strong financial sector so as to spur productive development and sustain consumption. Therefore while the motivation appears as predominantly a product of internal pressures, external conditions played a significant role if Canadian enterprises were going to compete internationally (Harvey, 2003). This in part explains, as will be discussed, why Canada led the charge against inflation and demands from workers for concessions amidst government restructuring. Unlike the U.S., Canada could not run huge deficits otherwise capital would flow out. The effect of austerity measures, in particular wage and price controls, was not only to make enterprises more competitive in world markets but to do so at the expense of devaluing previously sustainable livelihoods and occupations.

In other words, by the mid-1970s full-employment was officially abandoned in Canada as inflation-targeting and deficit reduction were prioritized (McBride, 2001). The Keynesian crisis radically halted the expansion of Canada's social programs and public goods and works investments. Through this period capitalism entered a deep international recession leading to an erosion of profitability (Gonick, 1987). This was the pretext leading to a sustained and intense period of capitalist class and state militancy. But just as public sector workers had finally gained the right to strike and bargain collectively, no sooner were those rights circumvented and reneged. The 
anti-inflation measures enacted by the Trudeau government in 1975 were in fact the precursors to the U.S.'s "shock therapy" and worked to radically undermine the growing politicization of public and private sector unionism. State measures gave the appearance of free collective bargaining while disguising the underlying turn to coercion. The resulting high levels of unemployment worked to discipline labour and undermine the growing militancy of trade unions. In what Harvey (2003, p.158) has identified as a 'massive enclosure of the commons', assets held by the state were forcibly released onto the market where capital could invest and discipline workers. These new spaces of commodification alleviated the problem of overaccumulation and, once set in motion, created pressures to continuously find more spaces where privatization could be achieved. Thus, the neoliberal restructuring of the relationship between the state and market must be seen as a 'radical embedding of an entrepreneurial logic' (Harvey, 2003, p.159) in what can be understood as a massive project of dispossession.

It is for these reasons that the Trudeau government established wage and price controls in the form of the Anti-Inflation Program for all workers under federal jurisdiction from 1975 to 1978. Wage increases were to be restricted to 10 percent during the first year of the program and then 8 percent and 6 percent during the following two years. What's more, in 1982 PM Trudeau extended for another two years wage and price controls, which were to be limited to six and five percent. It is not without irony that at precisely the moment when federal public sector workers began aligning themselves with the organized labour more broadly that the government moved swiftly to undercut their bargaining power. Just as federal workers moved from "collective begging to collective bargaining" (Warskett, 1997, p135) the federal government - under the guise of economic crisis effectively removed the right to strike and bargain collectively.

By this point the proportion of women in the public sector had risen from less than 10 percent at the end of the war to roughly 36 percent twenty years later. However, women remained 
isolated in low-paying and low-status spheres of employment with few opportunities for promotion and little decision making power in the workplace (Archibald, 1970). However, as is evidenced by the 50,000-strong clerks strike by the Canadian Employment and Immigration Union (affiliated to PSAC) in 1980, women were increasingly putting issues related to the gender wage-gap and "pinkcollar" job ghettos centre stage (McElligot, 1997). Warskett (1997) characterizes this turn to increased militancy as "learning to be uncivil." As events through the 1970s and 1980s demonstrated, women were increasingly debunking chauvinistic perceptions that characterized women as docile and conservative (White, 1990; Sangster, 2010).

A similar sequence of events was transpiring in Ontario. In 1970, the OLRA was amended paving the way for binding arbitration. But like the turn to austerity federally through the decade, Ontario provides a vivid portrait of deteriorating services and attacks against workers under the guise of economic crisis. In 1972 the shift toward a more formalized and confrontational approach to collective bargaining for Ontario public service workers was codified with the establishment of the Crown Employees Collective Bargaining Act (CECBA, 1972). As the name implies, for the first time civil service workers were finally granted the right to collective bargaining. However, in light of the significant restrictions included in the legislation the collective bargaining provisions were far from a real breakthrough. ${ }^{42}$ The legislation was introduced with the backdrop of striking hydro workers and municipal civic workers in the city of Toronto (Panitch and Swartz, 2003). Through the mid-1970s, militancy in the broader public sector intensified. For example, in response to the Davis government's unwillingness to bargain with teachers' unions and unilaterally imposed wage ceilings, layoffs, school board mergers, increases in workloads, class sizes and the cancellation of

\footnotetext{
${ }^{42}$ The CECBA provisions designated the Management Board of Cabinet (i.e. the Treasury Board) as the employer of the public service and outlined twenty-one exclusive managerial rights such as training, classification, job evaluations, staffing levels, technical changes and pensions (Roberts, 1994). Drawing on the recommendations of Little's report, the Act also excluded professionals and management, as well as casual, contract and temporary employees (less than 6 months experience), from the provisions of the CECBA (Carson, 2011). While CUPE, the OFL and CLC voiced strong opposition to the limited parameters of the CECBA which continued to deny civil service workers the right to strike, the CSAO expressed little discontent with the legislation (Hodgetts, 1995; Roberts, 1994).
} 
school programs, in December 197380,000 of Ontario's 105,000 primary and secondary teachers went on strike (Richter, 2006). Striking teachers employed work-to-rule tactics, letter writing campaigns, held large demonstrations at Queen's Park and submitted mass resignations. As Richer (2006, p.7) noted, teachers "now demanded free collective bargaining, the right to negotiate any term or condition of employment, and the right to strike."

While Davis's government had tried to threaten and cajole workers into accepting binding arbitration without the right to strike, mass public sympathy backed by militant teachers and widespread support from the broader labour movement, subsequently forced Davis to extend collective bargaining with the right to strike for teachers (Hanson, 2009; Laxer, 1976). By 1974, the CSAO - the largest and historically one of the most conservative public sector workers' associations - had finally come around to embracing a more confrontational, that is, political approach to collective bargaining. ${ }^{43}$ In December of the same year, Davis's government amended the CECBA to include casual and temporary employees, and expanded the scope of bargaining to include issues related to promotion, transfers, layoffs, job evaluations, reappointment and pay, and successor rights. However, issues related to classification, merit, performance evaluation and pensions remained the exclusive domain of management (Carson, 2011). The right to strike continued to elude the Ontario public service as there were no major changes to the CECBA legislation until the 1990s (Roberts, 1994; Carson, 2011). As a result of ongoing protests (e.g. workins, walkouts and solidarity strikes) by education, healthcare, utilities and transport workers, the right to strike was extended through the decade.

\footnotetext{
${ }^{43}$ That same year it launched the "Free the Servants" campaign replete with: "billboards, bumper stickers and buttons, featuring handcuffed trilliums. There were Davis Dollars, issued by the Bank of the Big Blue Machine, which paid civil servants 63 cents on the dollar. Activist carried a safety kit, with deodorant and Clorets to ward off the government's stench, and Alka-Seltzer and Tums for indigestion caused by management." (Roberts, 1994, p. 152-3). The CSAO had finally come around to demanding binding arbitration and the right to strike. Also, at its annual membership meeting in 1974 the CSAO - reflecting its embrace of formal unionism - changed its name to the Ontario Public Service Employees Union (OPSEU).
} 
In light of the economic downturn of the mid-1970s, the Report of the Special Program Review (also known as the McKeough-Henderson Report) introduced to the public lexicon the notion of "fiscal restraint." The Report held that excessive levels of government debt and inefficient public services weighed down the growth of the broader economy (McKeough and Henderson, 1975). In order to make government run more efficiently, the McKeough-Henderson Report espoused public sector cutbacks and a broad range of privatization measures. Taking their cue from the Report, in 1975 the Ontario Tories drastically reduced public spending, increased industrial incentives, froze the salaries of senior public service staff and discharged over 1,000 workers. As well, highway maintenance and snow plowing services were contracted out, psychiatric hospitals were closed, the number of available hospital beds reduced and health labs were sold to the private sector (Rea, 1985). Between 1975 and 1980, 7,000 public sector jobs were eliminated along with reductions in health care and educational spending (Roberts, 1994).

Through this period, large demonstrations by (the now-CLC affiliated) OPSEU, CUPE and other public sector unions, including considerable support from community activists, began slowly destabilizing the Ontario Conservatives' four decades-long tenure. Both CUPE and OPSEU continued to organize workers at universities, colleges, public services and utilities, paramedics and correctional facilities. Through the late-1970s and early-1980s, major strikes by administrative support workers, janitorial staff, jail guards, daycare workers and college staff signified the full embrace of political as opposed to limitedly legal unionism. By this point public sector unions were composed of more than 50 percent women (Roberts, 1994; Briskin and McDermitt, 1993), although they continued to be underrepresented in private sector unions (Warskett, 1997; Pierson and Cohen, 1995). Once 'secondary' issues such as maternity leave, child care, health and safety concerns, sexual harassment and sex-discrimination related to pay and promotion were now at the forefront of the labour movement. 
From 1978 to 1980 bitter strikes at Fleck Industries, K-Mart, Eaton's, Canadian Imperial Bank of Canada, Radio Shack, Blue Cross, Inco and elsewhere galvanized workplace militancy, particularly as a result of their fierce anti-union campaigning (Palmer, 1985). As a result of these pressures, in 1980 Ontario finally adopted the Rand formula. However, just two years later the Inflation Restraint Act in Ontario suspended the right to strike and extended all collective agreements by one year. The Act also prohibited wage increases in excess of five percent for roughly 500,000 public sector workers. The following year the Public Sector Prices and Compensation Review Act mandated that arbitrators consider employers' ability to pay in the arbitration process and made all collective agreements subject to review by the Restraint Board (Panitch and Swartz, 2003). This was a blatant intervention by the state which not only undermined free collective bargaining, but sought to shift the burden of recession from the private to public sector.

In 1982 the Canadian constitution was patriated establishing the Canadian Charter of Rights and Freedoms. The Charter essentially granted the federal government, via the courts, free reign over the granting of injunctions and back-to-work legislation with greater laxity and less parliamentary debate. ${ }^{44}$ For example, while back-to-work legislation was only implemented one time in the 1950s, it was used nine times in the 1960s and thirty-one times in the 1970 s (ibid). Reflecting on the undermining of the Keynesian welfare state and the hardening of the state, Panitch and Swartz (2003, p.6) argued:

"What we have witnessed is the passing of the era of free collective bargaining in Canada, one in which the state and capital relied, more than before the Second World War, on obtaining the consent of workers generally, and unions in particular, to act as subordinates in Canada's capitalist democracy. The era we have

\footnotetext{
${ }^{44}$ Despite the Charter's recognition of "freedom of association", a 1987 Supreme Court of Canada decision found that the right to strike and bargain collectively "are not fundamental rights or freedoms." The decision also gave the federal government essentially free reign over the designation of allocating workers as "essential." (McBride and Shields, 1997; Savage, 2009).
} 
entered marks a return, albeit under quite different conditions, to the more open reliance of state and capital on coercion - on force and fear - to secure that subordination." 45

Despite the implementation and extension of legislation recognizing the right to strike and bargain collectively, consecutive governments and businesses retained an ideological affinity to private enterprise trumpeting the classical liberal values of individuality and freedom. These values, at first quietly and later deafeningly, reestablished their dominance in the realm of public policy making as the neoliberal paradigm was consolidated. With the benefit of hindsight, these attacks against public services and workers signaled the opening salvo in what was to become an intense period of class struggle amidst state and capitalist militancy. It also slowly revealed the limitations of trade unionism as an end in itself, particularly absent a critical ideological and political perspective.

Between 1951 and 1981 public sector unions had grown from 14 unions representing 54,000 workers to over 70 public sector unions representing over $1,347,000$ workers (Rinehart, 2006). In the years which followed, federal workers across the public sector adopted a more militant stance with their employers. As argued, part of this more militant posture stemmed from the emboldened actions of the postal workers' unions which had a long history of job actions. In 1968, 1970, 1974, 1975,1978 and 1980 workers went on a variety of rotating strikes, wildcats, sit-ins and national strikes (Palmer, 1992; White, 1990; Parrot, 2005). In 1981 the Post Office was transformed from a government department to a Crown corporation, which entailed a change in labour relations jurisdiction from the PSSRA to the Canada Labour Code. As a result of the change, postal workers' unions would now be able to more fully negotiate issues related to layoffs, contracting-out, promotion and "essential" designations. Postal workers would take job action again in 1981, 1987,

\footnotetext{
${ }^{45}$ Framing the broader context within which these changes took place, Panitch and Swartz (2003, p.27-28) contend: "What marks this transformation was a shift from the generalized rule of law form of coercion (whereby an overall legal framework both establishes and constrains the rights and powers of all unions), toward a form of selective, ad hoc, discretionary state coercion (whereby the state removes for a specific purpose and period the rights contained in labour legislation)."
} 
1988, 1991 and 1997 before the turn of the century embodying the full articulation of political unionism (ibid).

By 1980 OPSEU represented nearly two-thirds of the provincial public sector, while CUPE represented near equal numbers at the municipal level. Over the period 1965 to 1981 , union membership in the education sector rose from 19,000 to more than 335,000 , while membership in the healthcare sector rose from 28,000 to over 205,000 (Rinehart, 2006). In 1980-81 roughly 10,000 healthcare workers at 50 Ontario hospitals organized by CUPE struck in defiance of mandated arbitration and laws prohibiting strikes by hospital employees. Demonstrative of the turn to coercion at the provincial sphere, the strike was ended one week later and was met with severe reprisals by the government: 34 workers were fired, 3,400 were suspended and 3 union leaders, including CUPE president Grace Hartman, were jailed for contempt of court for supporting striking workers (Pierson and Cohen, 1995). Later that year, 11,000 striking hospital workers at Riverdale Hospital organized with CUPE were legislated back-to-work, which resulted in strikers being charged with contempt of court and the union charged with criminal contempt and fined $\$ 250,000$ (ibid). With the implementation of the Inflation Restraint Act in 1982 and Public Sector Prices and Compensation Review Act in 1983, public sector workers were increasingly isolated as convenient scapegoats of economic recession. In tandem with the demise of the Keynesian welfare state was the ongoing dissolution of the postwar social pact. This compromise, although fragmentary and uneven from the very beginning, would continue to be undermined in the ensuing decades.

On the whole, therefore, the 1980 s can be understood as the beginning period of transition where the centre of gravity in the Canadian labour movement shifted from the traditionally male, blue-collar type industries to one increasingly centered in the public sector and female-led (Briskin and McDermott, 1993; Briskin, 2007). Large influxes of higher-educated women and racialized workers shifted prevailing orthodoxies leading to a more politicized public sector unionism. 
Consecutive federal and provincial governments increasingly came to embrace the ideological renaissance of laissez-faireism. From espousing a sense of redistributive justice and collective social responsibility in the quarter-century following the war, liberal virtues of individuality and personal responsibility continued to (re)assert themselves as the 1980s and 1990s wore on.

\section{Conclusion}

This chapter began with an overview of Keynes' theoretical insights. It was argued that, while Keynes' ideas advocated for the use of active fiscal and monetary policies, including the expansion of a broad range of social services, the general thrust of his work was concerned with stabilizing the capitalist system rather than altering it any fundamental ways. Far from a radical, Keynes sought to develop the necessary infrastructure that would expand and embed capitalist social relations at precisely the moment when its legitimacy was being called into question. Despite Keynes' limitations, however, his ideas contributed to the widespread acceptance of redistributive social programs and public investments.

With the conclusion of World War Two, the balance of class forces had shifted as labour unions and other progressive movements began agitating for improved pay and working conditions, and the extension of social security provisions. General welfare initiatives such as unemployment insurance, family allowances and old-age pensions entrenched a sense of collective social responsibility as the public came to expect more from their governments and employers. With the extension of collective bargaining rights through the 1950s and 1960s the terrain of legitimate trade unionism was simultaneously constrained and expanded: although unions were formally recognized as lawful actors bargaining on behalf of their memberships those same laws and regulations worked to entrench a system of highly specialized and legal provisions. As a consequence, the militant political mobilizations which had characterized the inter-war years fell to the wayside as legal negotiations and restrictions confined trade unionism to the collective agreement. Despite these 
tensions, public sector unions in particular increasingly came to espouse a politicized trade union movement casting off their previous hostility to working class politics. However, just as public sector workers were beginning to assert their right to strike and bargain collectively, wage and price controls over the 1970s and 1980s essentially nullified any genuine notions of free collective bargaining. The growing use of back-to-work legislation and injunctions, including the fight against inflation over full-employment, showed that the state was far from an 'impartial' umpire but a central player in aiding the capitalist class in taming and subjugating workers when market mechanisms for doing so fell short.

As the composition of the public sector shifted through the 1970s and 1980s, along with demands for improved pay and working conditions once subordinate issues were increasingly brought to the forefront as sexual harassment, maternity leave, child and elder care and sexsegregated employment were thrust at the core of workplace negotiations. The growing militancy of public sector unions backed by the radicalizing influences of younger, female workers would increasingly jettison their conservative past. As three decades of uninterrupted economic growth came to a standstill, the welfare state and trade unions increasingly came under attack as unaffordable and incompatible with the capitalist system. Over the decade, both the Trudeau and Davis governments would respond with harsh austerity measures restricting the parameters of free collective bargaining and, when necessary, removing them altogether. Similarly, private employers also responded with intensified efforts to resist unionization and curb wage militancy. As the foundation of the Keynesian compromise was slowly chipped away, neoliberal policy prescriptions espousing the virtues of the free market increasingly gained widespread reception in policy making circles, private business and the general public. With the abandonment of full employment policies in favour of inflation-targeting, Keynesianism was dealt its death-knell. As the following chapter will show, developments through the 1980s and 1990s punched large holes into the once durable 
social safety net, while workers in the public and private sector encountered a harsher bargaining climate.

Popular media, pundits, politicians and neoliberal trained economists increasingly portrayed public sector workers as lazy and wasteful, and redefined public services as inefficient and in need of market discipline. This shift in discourse was matched by an increasingly confrontational approach by the state, spurred by key business sectors and neoliberal think-tanks in dealing with labour strife. On the whole, therefore, while the right to strike and bargain collectively had been enlarged during the post war years, the widening gulf between, on the one hand, the legal right to strike and bargain collectively and, on the other, the active repression of workers exercising those rights had set in motion a precedent that would not only be continued but intensified in the decades that followed. Neoliberal orthodoxy increasingly established itself as the only alternative available. As the postwar compromise unraveled, industrial and public sector unions reached an impasse. 


\section{Chapter 3 - Neoliberalism and the Assault on Public Sector Services and Unions: 1984-2005}

I begin this chapter with an overview of the theoretical underpinnings of neoliberalism. It is necessary to do this in order to fully appreciate the underlying theoretical premises and central analytical propositions as they contrast with Keynesian policies. Throughout, I demonstrate how neoliberal policy prescriptions rose to prominence through the 1980 s, slowly displacing the welfare state and establishing itself as the orthodox political program. I contend that neoliberal policies have reconfigured public spending, social welfare initiatives and the relationship between the state, capital and labour. In authoritatively undermining public sector unions and imposing public sector austerity, I argue that neoliberal objectives have remolded labour market policies along increasingly individualized, competitive and precarious forms of work, which have exacerbated not only classbased antagonisms, but ethnic, racial and gender-based oppressions.

Moving from the theoretical plane to the concrete manifestations of such policies, I examine the period 1984 to 1994 where I claim that market-reinforcing policies became the only alternative available. I overview major public policy and legislative changes and detail the manner in which public sector unions were expected to bare the brunt of economic crisis-cum-austerity. I contend that as neoliberal-inspired reforms gained prominence in policy making circles, unions and public services increasingly came under attack as wasteful and unaffordable. From Mulroney to Chretien and Peterson to Harris, this resulted in a much more confrontational collective bargaining climate as unions resisted concessions and sought to politicize the restructuring of the public sector as a whole. In other words, public sector unions increasingly challenged the legal constraints of unionism as they came to understand collective bargaining as an equally important political process.

The subsequent section explores the period 1995 to 2005. Both the 1995 federal Liberal and Ontario Conservative budgets represent an intensified period of capitalist and state militancy in seeking to undermine unionism and drastically open-up public services to private sector 
provisioning. In this regard, I claim that the adoption of public sector austerity on the backs of public sector unions through this period represents the triumph of neoliberalism as the dominant policy paradigm. Although this chapter concludes with the election of two new governing parties at Parliament Hill and Queen's Park, their elections signaled not the repudiation of neoliberalism but its stealthily consolidation.

\section{Neoliberalism and New Spaces of Accumulation}

As both political philosophy and social policy, neoliberalism emerged in the context of the capitalist economic downturn that began in the early-1970s. As argued in the previous chapter, this downturn led to wide-ranging transformations in macro-economic and political structures as well as the social organization of work and labour market policy. As such, it is necessary to trace the theoretical development of neoliberalism as it supplanted Keynesian orthodoxy. From the very beginning neoliberalism was an "offspring of the Great Depression." (Mirowski and Plehwe, 2009). Having developed in tandem with but in the shadows of Keynesianism, neoliberalism's most vocal expositors took a long-established constitutive core of liberal ideas and refashioned them in new form. While neoliberalism draws significant intellectual inspiration from its classical predecessors, it has had a "decidedly nonlinear evolution" (Peck, 2008, p.3). ${ }^{46}$ Many of these transformative intellectual and policy changes have been incremental, yet systematically transformative. The archetypal expositors of contemporary neoliberalism, whose aim it was to recreate a liberalism suited for the ages, are best exemplified although by no means limited to the works of Ludwig Von Mises, Friedrich A. Hayek and Milton Friedman.

\footnotetext{
${ }^{46}$ As Peck has argued: "Neoliberalism...was a transnational, reactionary and messy hybrid right from the start. There was never a pristine moment of mountaintop clarity; it never represented a singular vision free of doubt and dispute. Instead, from its origins in the 1930s, neoliberalism signified an experimental and polycentric project aimed at the contradictory problem space between the state and the market. It represented an attempt to conceive and construct a market-(like) order, one that has since been perpetually reconstructed through practice (Peck, 2008, p.3-4).
} 
Chief proponents of neoliberalism remained largely marginalized through the first half of the 20th century. With the crisis of accumulation through the 1970s and into the 1980 s, however, they gradually emerged from the shadows of economic isolation as Keynesian policy prescriptions failed to kick-start the economic slump. Neoliberalism, as David Harvey (2005) has argued, can be understood as a political project seeking to restore and reconstitute class power through the (re)establishment of the conditions conducive to capitalist accumulation. As part of that process, leading expositors of neoliberalism increasingly gained prominence in well-funded think-tanks, such as the Institute of Economic affairs in London and the Heritage Foundation in Washington, in addition to playing an increasingly important role in formal academic affairs (ibid).

In Canada, political scientists, economists and sociologists trained in neoliberal economics and political theory at U.S. and British universities gained influence in the development of domestic curricula and hiring practices (Mathews and Steele, 1969; Cormier, 2004). The analogous growth in neoliberal think-tanks such as the Business Council on National Issues (later renamed Canadian Council of Chief Executives), the Fraser Institute, Atlantic Institute for Market Studies, and C.D. Howe Institute reshaped the contours of public policy advocacy (Langille, 1987; Abelson and Carberry, 1998; Carrol and Shaw, 2001). On the whole, reconstructing common sense was part and parcel of the neoliberal project. This "permanent campaign of persuasion" (Kozolanka, 2007, p.7), particularly among the active intelligentsia, sought to legitimate neoliberal policies and public discourses in both a theoretical and practical sense.

From the 1980 s, collective efforts on the part of the capitalist class sought to refashion the institutional configurations and social provisions of the previous thirty years. Neoliberalism emerged in this context as a means to discipline the growing power of labour militancy and enhance capitalist profitability. As more than thirty years of unprecedented economic growth came to a standstill, social expenditures increasingly came under attack by neoliberal-inspired politicians, 
economists and intellectuals as excessive and unaffordable. Workers were increasingly chastised by politicians, business sectors and media pundits as overpaid and underworked having allegedly become idle and unproductive (Workman, 2009; Duffy et al., 1997).

At the same time, finance came to play an increasingly larger role in the allocation of overall economic activity. As Albo et al. (2010, p.28) have argued:

\begin{abstract}
"What is called financialization involves not only credit markets playing a more pivotal role in the capitalist economy, but also economic development that is increasingly 'finance-led' in terms of the corporate decisions that determine investment flows and even the decisions individuals and households make in meeting their needs. Finance's enhanced place in the political alliances of capital and, in the power structures of the state, has gained it a more determining role in the shaping of government policy."
\end{abstract}

In this sense, the rise of finance was used to fight inflation, augment the wealth and income of creditors, internationalize capital, and use the growing indebtedness of the state to launch a full-out assault against social provisions and public sector unions under the auspices of economic crisis. Moreover, finance has been central to the disciplining of industry and the state through the - availability of credit and debt in the form of loans and guarantees. Although neoliberalism was from the very beginning a project intent on restoring ruling class power, it went beyond this thoroughly integrating and subordinating the working classes via mortgages, pensions and other forms of debt (Harvey, 2005; Dumenil and Levy, 2004; Albo et al., 2010; McNally, 2010). In this sense, "financialization gives rise to such financial volatility that crises actually become one of the developmental features of neoliberalism, and this reinforces rather than undermines the central position of financial interests in capitalist power structures." (Albo et al, 2010, p.35). Concomitant with the growing power of finance, and the capitalist classes more broadly, has been the neoliberal restructuring of the state.

Neoliberal proponents maintained that states ought to be limited to securing the institutional preconditions for a competitive market and, once established, remolding state practices in order to ensure market rule. As such, neoliberals proposed that states should be limited to the protection of 
private property, security, national defense and the legal enforcement of contracts. ${ }^{47}$ Like Von Mises in Bureaucracy (1944) and Hayek in The Road to Serfdom (1944), the Austrian and Chicago Schools of economics argued that government intervention into the economy was a problem since it obstructed the invisible hand of the free market (Milonakis and Fine, 2008) ${ }^{48}$ Proponents such as Friedman and Hayek asserted that markets inherently tended toward "general equilibrium" thus any "general gluts" (to borrow from Malthus) are wholly the result of government policies and intervention, and not indicative of overall market failure. Government efforts to secure basic social entitlements such as healthcare, education, pensions, unemployment insurance, welfare, workers compensation, maternity/paternity leave and so forth, are understood as intruding on individual rights and freedoms (Friedman 1962; 1980; Hamowy, 1982; Steiner, 2009; Van Horn and Mirowski, 2009).

As social paradigm and ideology, the market is envisaged as ensuring that factors of production are paid what they are worth, therefore supposedly removing the need for social infrastructure, legal and juridical protections and unions which are viewed negatively as market impediments. As a policy framework, central to neoliberalism has been the abandonment of full employment, national economic development and a shift from collective to individual culpability. This includes limiting wage increases to below increases in productivity, the systemic use of state power to impose market-imperatives and create new spaces for accumulation, monetarist shock therapy, regressive tax reform, the erosion and dismantlement of social services, inflation-targeting by the central bank, an export-led growth strategy, unlimited foreign direct investment and trade

\footnotetext{
47 These views were amply summarized by Freidman in his Capitalism and Freedom (1962) and Free to Choose (1980), where he advocates for: 'the elimination of taxes on corporations and progressive income taxes, public education, social security, government regulation of food and medicine, licensing of doctors and dentists, the post office monopoly, government relief of natural disasters, minimum wage laws and employment standards legislation, interest rate ceilings, laws prohibiting heroin sales and a host of other laws and regulations that supposedly impede profit making and personal choice' (Hunt and Lautzenheiser, 2011, p.480).

48 Naturally, there are important differences between the anti-statist Friedman and the minimalist Hayek, however the general thrust of the 'neoliberal thought collective' (Mirowski and Plehwe, 2009), is one oriented toward unleashing market forces with governmental oversight limited to ensuring maximum conditions for accumulation.
} 
liberalization. Moreover, this has entailed a movement away from government-led social programs and a (re)turn towards an increasing reliance on private charity through faith-based interventions, philanthropy and volunteerism (Pulkingham and Ternowetsky, 1997; Burke et al., 2000; Streek and Thelan, 2005; Peck, 2010).

As Brenner et al. (2010, p.188) have argued, "Since their initial appearance in the 1970s, neoliberalizing regulatory experiments have unfolded in a sporadic, yet-wave-like, non linear sequence, generating important cumulative impacts or sedimented patterings upon uneven institutional landscapes of world capitalism." Accordingly, the ongoing transformation of inherited regulatory frameworks and multi-level governance arrangements have reshaped the contours of institutional landscapes and rewoven interconnections among them. The subsequent tendency has been to limit the scope through which national discretion can be exercised through socio-spatial reconfigurations along market lines. Neoliberalism, then, can be understood as a fluid, ongoing process rich in change that has entailed the rescaling of political administration through multi-level governance arrangements via shifting territorialities in order to attract capital investment (Brenner and Theodore, 2002).

This has entailed the concurrent introduction of new state supports and mechanisms that facilitate private accumulation, in addition to the retrenchment of social protections provided by the state, and the simultaneous devolution and upwards transference of regulatory responsibilities, most often without matching fiscal supports or regulatory decision-making powers to other tiers of governments (McBride and Shields 1997; Streek and Thelan, 2005; Brenner, 1999; Brenner and Theodore, 2002). ${ }^{49}$ This also prevents progressive governments from using their regulatory authority to erect trade barriers against the goods and services from other political units, thereby

\footnotetext{
${ }^{49}$ Andrew Gamble $(1994$, p.36) has argued: "The state is to be simultaneously rolled back and rolled forward. Noninterventionalist in some areas the state is to be highly interventionalist and centralized in others." This line of argument has been expanded upon by Peck and Tickell, 2002.
} 
entrenching capital mobility and avoiding any centralization or harmonization of market-inhibiting policies (Harmes 2006). All this can be understood as the competitive re-regulation of neoliberalism within and between multi-level governments. In other words, the locking-in of inter-jurisdictional competition, with the aim being to marketize all spheres of social life. ${ }^{50}$

\section{Remaking Labour Market Policy}

In the context of stagnant economic growth through the 1980s, employers increasingly turned toward escalating the pace of work which has led to a growing precariousness of job tenure as well as heightened stress and work-life conflicts owing to long hours of work and lack of control over working time (Moody, 1997; Duffy et al., 1997; Shalla and Clement, 2007; Pupo and Thomas, 2010). In seeking to erode the standard employment relationship, these initiatives have further exposed workers and public services to the pressures of 'market forces'. As Standing (1999, p.42) has argued, these measures were designed to "weaken protective regulations, restrict collective institutions and strengthen pro-individualistic regulations" in an effort to curb the growing militancy of workers and reestablish high profit margins. So-called "flexible" labour market arrangements have increased the use of shift work, short-term contracts, workplace speed-ups, evening and overnight work, part-time labour, weekend work, rotating and split shifts, variable schedules, as well as casual and seasonal employment (Shalla and Clement, 2007; Broad, 2000; Vosko, 2006; Broad and Antony, 2006). With the erosion of the SER has exploded the use of atypical, nonstandard, contingent and casualized forms of work and labour. ${ }^{51}$

\footnotetext{
${ }^{30}$ Neoliberalism, of course, necessarily demands cultural changes as well (Connell, 2010). This includes the ability of ruling elites to develop a shared class consciousness, shape consensus in policy making circles and negotiate compromises when differences arise. As Kozolanka (2007, p.20) has argued, "...hegemony is successful when it becomes stripped of ideology and appears natural, as common sense, which returns our attention to the "ideological and symbolic state activities' that are instrumental in the constitution of neoliberalism." Such views are further propagated though the press, media, popular culture, prisons, churches and educational systems, which appear as 'neutral' and therefore impartial (Carroll and Caron, 2003; McChesney, 2008; Carroll, 2004; DiMaggio, 2010; Langille, 1987, Aronowitz, 2010). Unfortunately, a detailed exegesis of these concerns is beyond the scope of this paper as I focus on the structural and institutional reconfigurations.

${ }^{51}$ For Rogers and Rogers (1989), four key aspects are taken as indicators of precarity: the degree of certainty in employment; control over the labour process (linked to the absence or presence of trade unions); the degree of
} 
In an effort to reduce production costs and maximize profitability, many employers have adopted a neoliberal approach to employment, which is achieved through the temporary and discretional use of employment layoffs, labour intensification, the denial of benefits and retrenchment of wages. This has included the curtailment of free collective bargaining rights, management strategies that promote "multi-skilling", continuous re-training, performance-based pay and tightly controlled managerial practices and workplace supervision (Rubin, 2005; Braverman, 1998; Huws, 2003; Rinehart, 2006; Jackson, 2005). Just as class-based inequities are intensified under a neoliberal workplace framework, so too are race- and gender-based inequities (Clement and Myles, 1994).

Feminist political economists, for example, have identified gendered dimensions of neoliberal policies which often go unaccounted for in gender-blind analyses. For example, neoliberal policies have promoted the privatization of social services and a lack of support for child care which, in the context of persisting gendered divisions of labour, have increased the demands on women's responsibilities in the home (Bezanson and Luxton 2006; Jenson et al. 2003; Bezanson, 2010; Galabuzi, 2006; Vosko, 2000; Armstrong and Armstrong, 1994). Neoliberal policies have also reproduced patterns of gendered labour market inequality through transformations in income security policies that are premised on the male income earner model of paid employment. This dynamic serves to further individuate responsibility by ignoring how complex socio-historical structural relations constrain the space for choice and subjectivity.

A key aspect of neoliberalism is the increased individuation of economic risk, whereby neoliberal subjects are constituted through economic and political processes that promote the

regulatory protection through union representation or law (e.g. against unfair dismissal, discrimination); and income level (as even 'secure' jobs can be low-paying) (Rogers and Rogers, 1989). However, not all contract or part-time work is precarious: "sometimes it is progressive, sometimes regressive, and it can be both precarious and permanent" (Clement et al., 2010, p.57). As such, precarious employment remains a multidimensional and heterogeneous concept for understanding changes to the labour process and broader labour market changes (Vosko, 2006). 
commodification of all aspects of social life, including relations of social reproduction (Braedley and Luxton 2010; Jenson and Sineau, 2001; Bakker, 1996; Teelucksing and Galabuzi, 2005). This is especially pertinent to women and racialized groups in the public sphere where they have made the most gains and labour market segmentation is less pronounced in comparison with similar private sector work (Corman and Luxton, 1997; Armstrong et al. 2001; Braedley and Luxton, 2006; Pupo and Noack, 2010). All in all, the intrusion of neoliberal market mechanisms into public services and industries represents a frontier opportunity to harmonize downwards the quality, pay and working conditions of the public-sector with the private sphere. This will become explicitly clear both below and in the case studies that follow, which examine museum workers in Ottawa-Gatineau, Carleton University teaching assistants and contract instructors, and city of Toronto municipal workers.

As longstanding patterns of labour market inequities are exacerbated, patterns of racialized labour market inequality are intensified as neoliberal policies seek to weaken labour market protections and income security protections. Racialized groups are disproportionately represented in low-income occupations across the labour market and these employment patterns are reflected in overall employment earnings for racialized groups that are below the Canadian average, with racialized families two to four times more likely to fall below low-income cut-off measures (Choudry et al., 2009). Further, new immigrants are more than twice as likely as those Canadianborn to experience chronic low incomes (Abu-Laben and Gabriel, 2002; Bakan and Stasiulis, 1997). These employment and earning differentials have contributed to a broader racialization of poverty, where racialized groups are more likely than non-racialized groups to have overall earnings below the poverty line (Colour of Poverty 2007; Bannerji, 2000; Creese, 2007; Das Gupta, 1996; Galabuzi, 2006).

All that to say, as public policy becomes increasingly neoliberalized, ethno-racial and gender-based inequalities, rooted in fundamentally antagonistic class relations, are further 
intensified. As social services become gradually more market-dependant, the burden increasingly falls on historically racialized groups, women and immigrants to occupy the most precarious labour market positions (Braedley and Luxton, 2010; Teelucksingh and Galabuzi, 2005; Arat-Koc, 1997; Bakan and Stasiulus, 1997). The notion that unemployment is more a result of individual failure as opposed to market failure has come to dominate public policy debates as the principle of private responsibility over collective responsibility has shifted the boundaries of work and life. With the dissolution of the SER, workers are envisaged as individual entrepreneurs. ${ }^{52}$ As such, central to the new reality of work in the twenty-first century are increasingly insecure labour market arrangements, low-pay, the absence of benefits or entitlements and growing work-life imbalances. ${ }^{53}$

Such changes in the nature and content of public policy have had significant implications for labour market conditions. The generally inferior working conditions and wages of the private sector have become the new benchmark which, in the process, has provided the rationale for attacking public sector workers' compensation. There are some important differences in the public and private sectors however. Whereas casualization in the private sector has been mainly in long-term part-time work, in the public sector it has taken place primarily though temporary full-time work. Thus in the public sector, short-term full-time work has eclipsed permanent part-time employment as the main form of casualized labour in the public sector (Stinson, 2010). Given significant

\footnotetext{
${ }^{52}$ For example, consider a senior manager at one of the world's largest telecommunications providers: "In AT\&T, we have to promote the whole concept of the workforce being contingent, though most of our workers are inside our walls. "Jobs" are being replaced by "projects" and "fields of work" are giving rise to a society that is increasingly "jobless but not workless."...People need to look at themselves as self-employed, as vendors who come to this company to sell their skills" (cited in Perelman, 2011, p. 31).

${ }^{53}$ In fact, recent scholarship regarding the growing spread of precarious work is also revealing new insights. Lewchuck et al. (2011) propose that the labour market may be in the midst of a major shift in the interrelationship between production and social reproduction. Their data suggests that men and women's employment experiences are becoming increasingly similar. However, for the most part, this is not due to the expansion of women's employment opportunities and wages, but the result of the general downward convergence of wages and working conditions across the labour market. In other words, disparities typically associated with "feminized labour" are being replaced by dual precarious earner households. As they argue, "White male workers can no longer assume that secure labour market positions are theirs, while new opportunities for hidden forms of both gender and racial privileging/discrimination have merged in the less secure segments of the labour market, in the pay differences, constant scheduling, and rehiring/firing of temporary and contingent work." (Lewchuck et al., 2011, p. 94).
} 
structural forms of discrimination, such as those historically linked to the female gender wage-gap and racialized exclusions, transformations in the quality and form of work and working conditions remains important given that nearly one in four Canadians, sixty-one percent of which are women, work in the public sphere (ibid). The ongoing transformation of the public sector via policy prescriptions expounding the virtues of neoliberalism have perhaps been most apparent with the growing appeal of New Public Management theories (NPM), which have sought to "modernize" the public sector through "efficiency" generating principles based on private sector management models. ${ }^{54}$ NPM theories, like the overarching neoliberal framework in which it is embedded, seek to enhance capital accumulation by limiting trade unions' rights and freedoms, privatizing public services and employment, and establishing private sector labour practices in the public sector. As I argue below, the 1980s were a profound period of macro-economic and socio-political changes as public services and unions were increasingly expected to bare the brunt of restructuring in the midst of recession.

\section{Neoliberalism Moves Centre Stage: 1984-1994}

Among the first acts of business initiated by the newly minted Conservative government of P.M. Mulroney was to cancel the National Energy Program and set about a path toward market liberalization. The 1984 election of a majority Conservative government, the first in twenty-six years, can be understood as the abandonment of Keynesianism and the full embrace of neoliberalism..$^{55}$ Mulroney's government sought to simultaneously cut social welfare provisions and restrict the scope of collective bargaining rights for workers. Through the first years of Mulroney's

\footnotetext{
54 "This paradigm asserts that government, and more broadly, the public sector should function more like the private sector and should look to the market for inspiration and, whenever possible, emulate it." (Shields and Evans, 1998, p.56). By increasing market exposure proponents of NPM advocate a transition from public 'administration' to public 'management' via the privatization of public goods and services, a greater reliance on outsourcing and contracting-out, and user-pay provisions (Savoie, 1996). Competition between public agencies and private firms is alleged to increase cost-effectiveness while the use of short-term and contract labour, including performance-related pay and bonuses, are envisaged as constructing a "lean" state (Sears, 1999).

${ }^{55}$ Among his first official acts as Prime Minister, Mulroney travelled to New York City to address the Economic Club and declare that "Canada was open for business." (Laxer, 2009, p.165).
} 
tenure the Conservative government went to great lengths to remove the right to strike by extending the scope of workers deemed "essential." This included air traffic control personnel, clerical and administrative workers, operational staff, and scientific and professional employees (Panitch and Swartz, 2003). As will be argued, the use of back-to-work legislation was deployed more regularly while sanctions and penalties outlining illegitimate union practices were more severe. In 1986, the Mulroney government established a five-year plan to abolish 15,000 person-years and, by 1987 , over 100,000 workers in the seaway, railway and postal sectors were working under strict restrictions governing work rules, job security and wages (ibid).

Although the trend toward declining public investments was evident since the late-1970s, deficit reduction now permeated all avenues of social program spending. For instance, old-age pensions were partially de-indexed. Whereas in the past pensions rose with inflation, under the Conservative government's changes payments would only increase by the amount that inflation exceeded 3 percent which resulted in a gradual but inevitable depreciation in the real value of benefits (Battle and Torjman, 1996). In a similar vein, the Mulroney Conservatives drastically overhauled Unemployment Insurance by converting it from a tripartite arrangement between employees, employers and government to one solely financed by employers and employees. Benefits were reduced from 60 percent of insurable earnings to 55 percent by 1992 , and the number of weeks of benefit duration reduced from fifty to forty-five. This represented a major shift in public policy from one premised on collective social responsibility to an increasingly individualized social policy arena (Pulkingham and Ternowetsky, 1996). This was followed-up with the de-indexation and, eventually removal, of Family Allowances, as well as the implementation of workfare-style training and employment programs (Russell, 2000; Hunter and Miazdyck-Shield, 2000). In implementing such reforms, the state was taking a leading role in shaping and reinforcing an individualist as opposed to collectivist ethos. 
Re-elected in 1988, the economic downturn of the early-1990s was at that point the most significant and prolonged recession in Canada since the Great Depression (Stanford, 1999). This downtum intensified attacks against the social safety net and workers' rights and freedoms to strike and bargain collectively. In an effort to balance federal coffers at the expense of the provinces, in 1990 the Conservatives capped transfer payments to Ontario (as well as B.C. and Alberta), which resulted in a reduction of $\$ 400$ million in 1990-91 and roughly $\$ 4$ billion over the rest of their term (Couchene and Telmer, 1998). These cuts contributed to significant revenue shortfalls for the provinces and municipalities which depended on the stable financial support to fund social services and programs. In 1991 the Mulroney Conservatives passed the Public Service Reform Act, which empowered cabinet to suspend workers' right to strike by Order-in-Council during an election period, unilaterally expanding essential designations and altering the conditions of employment. This also extended management's abilities to contract-out employment and increased the use of part-time and casual labour in the public sector (Savoie, 1996; Panitch and Swartz, 2003).

Furthermore, in 1991-92 federal salaries were frozen, with wage increases limited to 3 percent for the next two years. In response to draconian state measures, on September 9, 1991 upwards of 50,000 PSAC members went on strike (Warskett, 1997). However they were legislated back-to-work less than a week later. Under a challenge to the Labour Relations Board, the Mulroney government was found guilty of bargaining in bad faith and 12-days later PSAC workers went back on strike. Despite the ruling against the government, however, they were once again legislated back-to-work shortly thereafter. Under the provisions of the new legislation, all public sector workers' wages were frozen for the first year and then capped to increases of 3 percent for the second year (ibid). Shortly thereafter, CUPW engaged in a number of rolling strikes to protest the erosion of collective bargaining rights but, like PSAC, they too were soon legislated back-towork (Parrot, 2005). In line with neoliberal policy prescriptions expounding the virtues of private 
sector-led economic growth, more than two dozen Crown corporations and agencies, including deHaviland, Canadair, Air Canada and Petro-Canada, were sold-off in an effort to shed so-called public liabilities (Rinehart, 2006; McBride and Shields, 1997).

In seeking to more closely align North American business interests and remain competitive in U.S. and international markets, the Mulroney government replaced the Trudeau-era Foreign Investment Review Act with the Investment Canada Act which drastically reduced the appraisal and oversight of foreign direct investments. Closer integration with the U.S., which circumvented the domestic macro-economic planning capacities of federal and provincial governments, was cemented with the passing of the Free Trade Act in 1988 which bound Canada to a neoliberal policy program (Grinspun and Kreklewich, 1994). Through the 1990s all mainstream parties shifted right as neoliberal market orthodoxy came to dominate the legitimate realm of political debate (Carroll and Ratner, 2005). This was most clearly advanced with the election of the Chretien Liberals in the 1993 election.

The Liberals were elected on a platform promising to renegotiate the impending North American Free Trade Agreement (NAFTA), scrap the Goods and Services Tax, reform UI and relax monetary policy while balancing the federal budget. After the election, the Conservatives were reduced to two seats, while the budding emergence of the Alliance and Reform parties embodied the sharp turn nationally to the political right (Laycock, 2002). Almost immediately after the election, the Chretien Liberals extended the Mulroney wage freeze for federal public sector workers for another two years, and signed the North American Free Trade Agreement with the U.S. and Mexico with minimal amendments (Ayers, 2004). Like the federal wage freeze which sought to curb inflation on the backs of public sector workers, NAFTA embedded neoliberal reforms by constraining the scope of government intervention to market-reinforcing policies (Jackson, 1999). 
A similar embedding of neoliberal policies was occurring at the provincial and municipal levels. Although Ontario had long been a province dominated by Progressive Conservative (PC) rule, much had changed over the postwar era. From the mid-1940s to mid-1980s, Ontario had been transformed from a partially agrarian economy rooted in the family farm to an increasingly urbanized manufacturing and service economy in the south and a resource and extraction economy centered on mineral and forest wealth in the north (Macdermid and Albo, 2001). In the dying days of the Bill Davis government, it was becoming increasingly apparent that a very different Ontario was emerging. Ongoing labour strife in the manufacturing sectors, such as Inco workers in Sudbury and Stelco and General Motors workers in the Golden Horseshoe (Palmer,1985), as well as outbursts of discontent among public sector workers such as the 1985 strike by Toronto transit workers and subsequent back-to-work legislation, were beginning to wear on the political fortunes of the ruling Conservatives (Albo and MacDermid, 2001).

The Ontario general election in the Spring of 1985 ended in a stalemate of sorts. Although the PC's had won more seats (52) than the Liberals (48), the latter had won slightly more of the popular vote. Finishing in third, the NDP with 25 seats held the balance of power. Showing little interest in continuing the Conservative dynasty which had ruled Ontario for more than four decades, the NDP signed an Accord with the Liberals agreeing to support a Liberal minority government for two years, while the Liberals agreed not to call an election during that time. It is my contention that the Peterson Liberal government can be understood as the last gasp of Keynesianism in Ontario. In comparison with their Conservative predecessors, the Liberals' first budget resulted in a wide array of modestly redistributive social program spending and public infrastructure initiatives. This included: new investments in youth training and employment, the creation of 10,000 non-profit housing spaces, increases in post-secondary education and healthcare spending, northern development grants, 10,000 new subsidized childcare spaces, and small increases in personal and 
corporate tax rates. Many of these new spending arrangements represented a break with the preceding minimalist approach of the Conservatives, although a good portion of the renewed public spending merely caught up with the legacy of past underinvestments and social welfare erosion (Government of Ontario, 1985; 1986).

Moreover, given that the NDP held the balance of power and was gaining popular support through the province, they were able to use their leverage to push through renewed public investments. However, it was the Liberals that were to benefit the most from the expiration of the Accord as the public came to attribute many of the positive changes to their mandate (Rachilis and Wolfe, 1997). The Liberals emerged from the 1987 election with a strong majority outnumbering the New Democrats and Conservatives' number of seats by a ratio of nearly three to one. The next three years of the Peterson government continued along the path of moderate Keynesianism with ongoing investments in healthcare and education, municipal transportation, housing, childcare and social assistance, including targeted grants, subsidies and tax relief for the agricultural, mining, manufacturing, information and technology sectors (Government of Ontario, 1985; 1986). By the late 1980s the Liberals were arguing that federal downloading had resulted in over $\$ 1$ billion in lost revenue (Ontario Budget, 1988; 1989). In an attempt to partially offset eroding revenues, the Liberals raised a broad range of consumption taxes on gasoline, tobacco and alcohol, and increased the provincial sales tax from 1 to 8 percent. However, like the federal government which reduced corporate and personal income taxes in the late-1980s, the Ontario Liberals followed suit reducing capital taxes and lowering from ten to three the number of personal income tax brackets. As others have argued, the move away from progressive corporate and income taxes are not only socially and economically regressive, but signifies the broader movement away from collective social responsibility to an increasingly individualized social policy arena (Stanford, 1999; Carroll and Shaw, 2001). 
Although real growth in Ontario had exceeded 4 percent per year from 1984 to 1989 (the largest and most sustained since the 1960s), federal cuts to shared-cost arrangements made themselves felt on Ontario's fiscal balance sheet as signs of a deteriorating economic climate were increasingly on the horizon (Klassen and Buchanan, 1997). In an act of political brinkmanship, the Peterson Liberals called a snap election just three years into their majority mandate. In the ensuing election campaign Peterson's government was accused of political opportunism as there were no defining issues polarizing the electorate (Evans and Shields, 2011). The Liberals were accused of simply trying to win reelection before the economic downturn worsened. On September 6, 1990, the NDP gained the most from the Liberal's inopportune election call. For the first time the NDP became the governing party of Ontario, winning a majority government, while the Liberals were reduced to the Official Opposition and the PC's to less than one-fifth of total seats (Rachilis and Wolfe, 1997).

Bob Rae's NDP ran on a progressive platform emphasizing investments in social services, healthcare, education, infrastructure and changes to employment standards legislation. This included promises to raise corporate taxes, increase minimum wages, expand childcare and social assistance, public housing, rent control, public transportation, stricter environmental regulations, employment equity and public auto insurance (Rachilis and Wolfe, 1997; Walkom, 1994; Azoulay, 2000). However, just as the New Democrats were elected to government they found themselves with a much-changed fiscal and economic climate as the recession of the early-1990s temporarily reduced corporate profitability leading to a concentrated strings of layoffs, particularly in the manufacturing sectors which gave impetus to capitalist and state restructuring. In light of unemployment having jumped from 5.1 percent in 1989 to 10.9 percent in 1992, welfare costs drastically rose while declining tax revenues increased the indebtedness of provincial coffers (Gower, 1996). Having inherited a $\$ 3$ billion deficit from the Peterson Liberals, the NDP found the 
deficit to be growing at a much faster rate than anyone had anticipated. By 1991 the deficit was estimated to be in the then-record range of $\$ 10$ billion, while job losses continued to grow in cities across the province, as they did in Toronto where 78,000 jobs were lost in the first year of the recession (Panitch and Swartz, 2003).

The economic crisis of the 1990s was intensified by the Bank of Canada's emphasis on antiinflationary high interest rates, which ignored rising unemployment. By 1993 some regions were experiencing unemployment rates bordering on 14 percent (Gower, 1996). By the mid-1990s a very different Ontario had emerged than that which had predominated during the Keynesian era. From the mid-1950s to mid-1990s, manufacturing as a percentage of total employment shrunk from 31 to 21 percent, while services grew from 47 to 74 percent (Thomas, 2009). The short-term intensity of the economic crisis coupled with longer-term structural changes proved fatal to the NDP government who offered up little more than mainstream neoliberal prescriptions. Whereas the NDP's first budget included spending increases to public services and renewed investments in public infrastructure, the NDP quickly retreated from the more ambitious increases in corporate and wealth taxes as well as public auto insurance succumbing to the fiscal orthodoxy of balanced budgets (Azoulay, 2000; Walkom, 1994).

These shortcomings aside, the NDP amended both the Employment Standards Act and Labour Relations Act improving workers' ability to recover unpaid wages, enhancing pay equity provisions, expanding the rights of domestic and agricultural workers to organize, placing restrictions on the use of replacement workers, increasing the remedial powers of the OLRB and extending the rights of unions to "combine" bargaining units within the same company. The NDP also reformed the grievance arbitration process, expanded "successor" rights, extended the right to first contract arbitration, expedited the hearings process and lowered the threshold for triggering certification (Smith, 2009). Despite the contradictory mixture of fiscal orthodoxy and labour 
progressivity, however, the business lobby remained vehemently on the attack. High levels of business opposition to Rae's government - representing upwards of 85 percent of the largest corporations in the province - engaged in a wide variety of public relations efforts to actively undermine the progressive labour changes, despite deep cuts in public spending (Walkom 1994; Kaplan 2010).

Soon after amending employment standards legislation and the Ontario labour relations Acts, the NDP brought together all public sector unions to discuss the state of Ontario's fiscal balance sheet. In an effort to trim the deficit, the Rae government sought to, first, institute an Expenditure Control Plan which would cut 11,000 public sector jobs while finding another $\$ 4$ billion through "efficiency" generating restructuring. And, second, implement the infamous Social Contract which would cut $\$ 2$ billion through a three-year wage freeze for 900,000 public sector workers, including a 5 percent reduction in wages through 12 unpaid days-off. Income and consumption taxes were also raised to the tune of $\$ 2$ billion (Walkom, 1994; Rachilis and Wolfe, 1997). In the Spring of 1993 the Rae government unilaterally altered the terms of previously negotiated public sector contracts and imposed a three-year wage freeze that voided earlier agreements. The NDP also amended the Crown Employees Collective Bargaining Act which finally extended the right to strike to public service workers. However, soon after the NDP passed the Orwellian-titled An Act Respecting the Collective Bargaining Rights of Employees of the Crown, they statutorily prohibited workers from exercising those very same "rights." (Panitch and Swartz, 2003).

In singling-out the public sector, the NDP failed to consider alternative revenue-generating means such as the raising of corporate and income taxes, wealth and inheritance taxes, sales taxes on luxury goods, capital controls or domestic reinvestment quotas on foreign capital, instead falling back on the neoliberal mantra that public services are inefficient and union salaries unsustainable. In 
other words, amidst the deep recession of the early-1990s the NDP government characterized Ontario's fiscal problems in terms of union resistance to public expenditure cuts, rather than a result of the systemic failures of the market (a theme to be repeated in the case studies that follow in subsequent chapters). Absent from the narrative was any serious discussion of the history of chronic underfunding of public infrastructure, the regressivity of tax reforms, federal downloading onto the provinces, the resistance of leading sectors of the capitalist class to pay a fairer portion for the maintenance of the public good or a deep critique of neoliberalism, let alone capitalism. ${ }^{56}$ Instead, the NDP adopted the mantra of neoliberalism which further fragmented progressive and anticapitalist forces, the trade union movement and led to a general crisis of Keynesianism and social democracy (McBride, 1996). Over the course of its term, the NDP government in Ontario fully adopted the narrow confines of neoliberalism, treating the recession and deficit not as a symptom of capitalism's propensity to crises but as a result of spendthrift public services and so-called lavish union salaries. This reflected the NDP's political and ideological embrace of neoliberalism as the policy prescriptions separating the three major parties grew thinner. With the 1995 election of Mike Harris a new form of conservatism emerged in Ontario, one which would advance the neoliberal agenda to new heights.

The Continuing Assault Against Public Services and Unions: 1995-2005

As McBride and Shields (1997, p.81) have argued, the 1995 federal budget marked a fundamental shift in the role of the federal government: "It marks the point where erosion of social programs ended and demolition seriously began." The 1995 budget terminated the Canada Assistance Plan and Established Programs Financing, replacing them with the Canada Health and

\footnotetext{
${ }^{56}$ In fairness, an exception was Rae's "fair shares federalism" campaign, which protested the "cap on the CAP" amidst dwindling transfer funds to Ontario. However, like Peterson's Liberals before and Harris's Conservatives after, this was far from a real critique of the causes of the declining revenue transfers (and the neoliberal policies which sustained them) than it was a general complaint of its consequences - i.e. declining transfers. All in all, the neoliberal paradigm remained unchallenged.
} 
Social Transfer (CHST). The CHST represented a significant reduction to provincial transfers in the realm of social assistance, post-secondary education and healthcare funding. The new block funding removed the previous 50/50 cost-sharing arrangement and replaced it with a combination of cash and tax points transfers, which were frozen at 1995 levels for the next five years (ibid). This unilateral devolution of welfare responsibility served to decentralize federal funding leading to an erosion of national enforcement standards and reduction in the quality and scope of public services.

Given the emphasis on deficit reduction, the shift away from the CAP/EPF to the CHST represented a reduction of social services funding in the realm of thirty to thirty-five percent (Prince, 1999). With the erosion of federal funding pre-conditions, downloading also granted provincial governments greater discretion over how to use those funds which gradually opened the door to increased marketization of social services, especially those linked to healthcare, education and welfare (Armstrong et al, 2001; Turk, 2000). Whereas the CAP/EPF prohibited "work for welfare" as a condition for receiving social assistance benefits, with the introduction of the CHST many provinces began to experiment with new workfare arrangements which further entrenched market mechanisms. ${ }^{57}$ This was followed up with changes to the UI system in 1996 which reduced benefit rates, imposed stricter entrance and reporting requirements, disqualifying leaves and claim duration (Pulkingham and Ternowetsky, 1996). Indicative of the discursive influence of neoliberalism, UI was renamed Employment Insurance (EI) reflecting the failure associated with unemployment and ideological embrace of workfarist policies. Whereas in 1987 UI covered approximately 83 percent of unemployed Canadians, under the new EI Act this number had dropped

\footnotetext{
${ }^{57}$ For Jamie Peck $(2003$, p. 75$)$ : "Workfare is a social-policy neologism referring to mandatory work programs for welfare recipients or, more generically, to the process of work-oriented welfare reform...[W]ork-based or workenforcing welfare policies have been favored by politicians of the right for some considerable time, bolstered by the perennial concern that "no strings attached" welfare entitlements erode the employment habits, job skills, and work ethics of the poor. Support for workfare-style policies widened during the 1980s, as centrist liberals became increasingly convinced of the argument for "tough love" approaches to welfare reform." In other words, workfare obliges recipients to do unpaid labour for welfare, in addition to continuing to seek paid-employment. Workfare itself is not a training program, and participation is most often a mandatory requirement. In addition to Peck above, see Broad and Hunter, 2010, as well as Vallaincourt, 2010 for a critique.
} 
to 42 percent by 1997 and in some instances, as was the case in Ontario, barely 30 percent (Prince, 1999).

By 1975 CUPE was Canada's largest union and by the 1980s and 1990s was amongst the largest, most resourced and militant within the Canadian labour movement (Heron, 2012, p.98). For example, PSAC covered more than two-thirds of all federal employees, while CUPE had grown to be the largest union in Canada and the first to break the 400,000 member threshold (Rinehart, 2006). ${ }^{58}$ Likewise, between 1941 and 1996, women's labour market participation rates had increased from 20 percent to 71 percent (Thomas, 2009). In tandem with the severe expenditure restraint measures, the Chretien Liberals also looked to extract concessions from public sector workers in an effort to cut costs and increase workplace flexibility. For instance, following the 1995 federal budget PSAC lost 21 percent of its membership within three years as a result of layoffs, leaving vacancies unfilled and retirements (Fudge, 2005). Indicative of the outright use of coercion, both CUPW workers in 1997 and PSAC workers in 1999, were legislated back-to-work within a week of their strike actions (Parrot, 2005; Panitch and Swartz, 2003). In a first, the government also preemptively put an end to job actions by PSAC prison guards set to exercise their "legal" right to strike. Following in the footsteps of Mulroney, but going much further, Chretien's Liberals embraced NPM strategies laying-off more than 50,000 workers and selling-off dozens more Crown corporations and agencies such as the Canadian National Railway and NavCanada (McBride, 2001). From the early 1980 s to the late 1990 s, federal expenditures as a percentage of GDP fell from 20 percent to 17 percent, while program expenditures fell from 16.7 percent to 11.3 percent. In healthcare, for example, federal transfers to the provinces were reduced from 50 percent to 11 percent (Kozolanka, 2007), while core federal employment fell by 20 percent (McBride and Whiteside, 2011). All in all, over the preceding decade public services and expenditures were

\footnotetext{
${ }^{58}$ Although, as Ross (2006, p.426) reminds, by 1999, 92 percent of CUPE's more than 4000 strong unions were composed of 500 members or less, "indicating a very fragmented presentational structure."
} 
drastically reduced and opened-up to private sector provisioning, while it was demanded that public sector unions get used to lowered expectations.

If the 1995 Liberal budget is indicative of the point where 'erosion ended and demolition began' federally (McBride and Shields, 1997), the 1995 Ontario budget perhaps represents the single-most draconian exercise of "slash and burn" neoliberalism ever experienced in Canada. The election of the Mike Harris Conservatives signaled the integration of neoliberal orthodoxy along simple, straightforward and easily conveyed messages - tax cuts, less government, welfare reform and enhanced business investment - all captured under the party's platform of the Common Sense Revolution (CSR). It also demonstrated the elasticity of the electorate as Ontario elected in succession three different majority governments of varying political affiliations. With the election of the Conservatives austerity and public sector retrenchment became the only alternative available. The CSR platform promised to cut welfare payments, end employment equity, cut corporate and personal taxes, shrink the size of the public sector, rein-in the power of "big unions", create entrepreneurial opportunities and flexibility through downsizing and contract-out all the while balancing the budget (Ralph et al, 1997; Blizzard, 1995). Additional assurances included cutting the number of members of parliament, introducing work for welfare measures, cutting the number of school boards and trustees in half, reducing "waste and inefficiency" in the public bureaucracy, commercial incentives for healthcare and post-secondary education, scrapping job training programs, reducing public housing and transportation subsidies, easing environmental restrictions, and injecting market forces into the public sector through the use of public-private-partnerships (P3's) (Red Tape Commission, 1997; Winfield and Jenish, 1998; Boyd, 1997). 
In addition to the outright dismantling of social program spending ${ }^{59}$, the Harris Conservatives established the Red Tape Review Commission whose aim it was to eliminate policies that impeded "competitiveness" or placed "inappropriate regulatory measures" on businesses (Red Tape Commission, 1997). The PC's also introduced Bill 7, An Act to Restore Balance and Stability to Labour Relations and to Promote Economic Prosperity, which repealed the amendments to the OLRA introduced by the NDP and reformed union certification procedures. This included substantially rewriting Ontario's labour and employment laws in order to make the province "open for business" by replacing automatic certification following card signing with an election model using secret ballots, eliminating the prohibition on replacement workers during strikes, reducing the threshold to trigger decertification, putting limitations on when unions could call a strike vote, removing successor rights for public sector unions, imposing a 12-month ban on a lost certification vote, lowering the threshold for decertification, and repealing the rights of agricultural and domestic workers' to unionize (Panitch and Swartz, 2003; Smith, 2009).

By the end of 1995 the PC's had also introduced the Savings and Restructuring Act, which included drastic cuts to social expenditures, the elimination of 13,000 public sector jobs, new powers that unilaterally allowed Queen's Park to restructure municipalities and hospitals, constrained the scope of arbitrators adjudication powers, limited the remedial powers of the OLRB and froze the minimum wage at $\$ 6.85$ (where it would remain until 2004). Bill 49 also reduced the

\footnotetext{
${ }^{59}$ A non-exhaustive survey of cuts includes: the reduction of social assistance rates by 21.6 percent, the equivalent of roughly $\$ 1.4$ billion over two years; a moratorium on the development of non-profit housing and cooperatives; the suspension of $\$ 234$ million worth of spending on transit, roads and highways; the elimination of recycling funds and environmental grants totaling \$24 million; a \$290 million reduction in funding to the Ontario Municipal Support Program; over $\$ 12$ million in cuts to public libraries; the cancellation of the conversion of private-sector childcare spaces into non-profit spaces; the elimination of jobs training; the repealment of the Employment Equity Commission and Employment Equity Act; the reduction of the Ministry of Labour by one-half, or 457 employments standards officers and staff; the reduction of college and university funding by over $\$ 420$ million and increases in tuition varying from 10-25 percent; the reduction of transfers to school boards by $\$ 400$ million; a host of personnel expenditure and administrative costs reductions totaling over $\$ 1.1$ billion; the reduction of transfers to agencies, boards and commissions by $\$ 220$ million; over $\$ 1.3$ billion in health care cuts, not to mention an additional reduction target of $\$ 500$ million in operational spending. Total cost savings from this exercise in social spending demolition was estimated to achieve "savings" upwards of $\$ 5.5$ billion (Government of Ontario, 1995).
} 
time limit for workers to register formal complaints with the OLRB from two years to six months, and capped awards at $\$ 10,000$ regardless of the damages incurred (Thomas, 2009). The 1996 Ontario budget consolidated and extended many of the initiatives announced in the 1995 budget, and also reduced Ontario's income tax rate by 30.2 percent over three years, in addition to implementing an array of new user-fee charges such as a new healthcare levy and reductions to the state funded portion of post-secondary education (Government of Ontario, 1996). The Tory government also moved quickly to privatize water analysis and healthcare laboratories, including the elimination of 29 hospitals, over 10,000 hospital beds and more than 6,000 nurses (Armstrong et al, 2001; Perkel, 2002; Sutherland, 2011).

In light of the severe climate of austerity and mounting attacks against the public provision of social services, including the threat of 13,000 OPSEU layoffs, on February 26, 1996, over 50,000 OPSEU members went on strike protesting the authoritarian neoliberalism of the Mike Harris Conservatives (Rapaport, 1999; Reshef and Rastin, 2003). For the first time core public service workers in Ontario were on strike as a result of the 1993 amendments to the CECBA which granted them the right to strike. Despite wages being frozen at 1991 levels, the union did not ask for a wage increase. Instead, OPSEU was most concerned about issues related to job security, successor rights and retraining guarantees. Despite the protests by OPSEU, the government responded with no successor rights, faster layoffs, reduced contributions to the union's pension plans, reductions in the number of full-time staff and the unlimited use of unclassified positions (Borowy, 2006; Kozolanka, 2007; Rapaport, 1999).

The strike reached a turning point on March 18 when at the start of the Spring session union activists and protestors at Queen's Park were violently assaulted by the Ontario Provincial Police, pepper-sprayed and jailed for their efforts. The government aggressively used the legal system to undermine OPSEU job actions by filling out more than thirty applications at the OLRB and eighty- 
two court actions seeking to reduce the visibility of strikers and limit picketing (Kozolanka, 2007; Rapaport, 1999). Despite the efforts of workers to resist the CSR, one year later the Conservatives were able to lay off upwards of 11,000 staff; but arbitration awards in favour of the union would limit further attempts at privatization (ibid). Whatever the shortcomings of the OPSEU job actions, it is important to stress that these strikes represented political protest actions against the Harris government's neoliberal agenda. In many ways, this expanded the conventional realm of trade union militancy beyond 'bread and butter' workplace issues and into the social and political arena tying issues related to austerity and retrenchment to the broader attack against working class standards of living. In other words, this expanded the terrain of class struggles beyond the workplace and extended the attack against the public sector to include the users of those services, the gendered and racialized components of austerity, the undermining of free collective bargaining and the structural constraints of neoliberal public policy. But it also revealed the limits of that resistance as workers were unable to go beyond militancy and transform that discontent into an alternative political and economic project.

Unfazed by the experiences of the OPSEU strike, the PC's continued along the path of privatization and contracting-out. In 1997 GO Temp, the provincially-run temporary employment agency, was privatized. At the same time, dozens of meat inspectors were laid off and later re-hired as solo self-employed workers and prohibited from unionizing, while the government increasingly came to rely on female labour to fill part-time and temporary contracts (Borowy, 1996; Reshef and Rastin, 2003). Later that year, the PC's passed the Public Sector Accountability Act in order to "ensure that the private sector has an open opportunity to compete to provide services", which included setting new private sector performance benchmarks for the public sector (Government of Ontario, 1997). As part of the Conservatives' programme of "competitive austerity" (Albo, 1994), they began a series of municipal amalgamations that reconfigured the urban labour market and 
municipal political economy more broadly. For instance, under the provisions of Bill 103 - The City of Toronto Act - seven cities were merged creating the new City of Toronto. This involved a massive devolution of program spending and responsibilities onto municipalities such as social services, public school services, non-profit housing, roads, public infrastructure, long-term healthcare, childcare, shelters, aid societies, ambulance, fire and police services, waste collection, as well as public health and transportation (the consequences of which will be explored further in chapter 6). The movement away from shared-cost provincial-municipal funding shifted the burden of responsibility from general income and corporate tax revenues at the provincial tax base to the narrow realm of municipal property taxes (Boudreau, 2000; Bashevkin, 2006; Hiller, 2010).

Just as the federal government had begun doing two decades earlier, the provinces downloaded a whole range of services onto municipalities without an equivalent transfer of funding or matching fiscal supports. Amalgamation was in the interest of all Ontarian's, the PC's argued, as it would lower costs, remove barriers to investment, enable private sector job creation and increase the political coherence and economic efficiency that "global cities" demanded (Kipfer and Keil, 2002). The PC's suggested that Toronto could realize upwards of $\$ 865$ million in savings alone over the first three years through amalgamation as a report by the accounting firm KPMG alleged, but this was later contradicted by a report from Deloitte and Touche that showed that savings would be next to none (Kozolanka, 2007). Like Toronto, the cities of Ottawa, Hamilton, Greater Sudbury and the Kawartha lakes were also amalgamated. However, as subsequent research (Boudreau et al, 2009; Hiller, 2010), including chapter 6 of this study makes clear, the cost-cutting exercise did not generate any real savings, but rather wide-ranging cuts to public services, lower service level provisions, recurring municipal fiscal deficits and ongoing labour strife.

Before the end of Harris's first term, more than 126,000 teachers across Ontario took part in extralegal job actions in protest to the Education Quality Improvement Act. The Act unilaterally 
centralized control over education curricula, repealed employment equity initiatives, abolished Grade 13, standardized testing and report cards, and amalgamated school boards while reducing the number of trustees (Gidney, 1999; MacLellan, 2009). ${ }^{60}$ Like the OPSEU strike, the October 1997 Ontario teachers' strike was not just a workplace issue in the limited sense but a political strike over the direction and quality of education, the future of public services and the ability of teachers, students and parents to meet local demands and needs. Besides signifying a climate of coercion and absolutist bargaining on the part of government, the strike was significant because it demonstrated the social and political potential of a united, province-wide protest movement notwithstanding its limitations. ${ }^{61}$

Like Rae before him, Harris used the strike to portray "big labour" as self-interested, uncompromising and opposed to change. These views were propagated by a host of media outlets, newspapers and magazines, which reproduced such depictions (Kozolanka, 2007). The government sought to shift the conflict from the streets into the courts by increasing the use of injunctions. While this tactic was ultimately unsuccessful, it is an example of what Glasbeek $(1999, \mathrm{p} .805)$ has called the "anti-workers architecture of the law and the mandate of the courts in depoliticizing capital-labour disputes." Despite ample public support and local actions in favour of the political strike by teachers, such as the Coalition for Public Education and the Ontario Education Alliance, most teachers' unions had returned to work by early-November. Demonstrative of ongoing public

\footnotetext{
${ }^{60}$ Minister of Education at the time, John Snobelen, spoke of "creating a crisis" in the education sector as a means of achieving political goals: namely weakening teacher unions and reducing education expenditures. Moreover, under the provisions of the Act teaching and staff related positions were reduced by nearly 7,000 positions, upwards of 8,000 principals and vice-principals were removed from bargaining units, and the government retained absolute power to determine class sizes, teacher preparation time, student-teacher ratios, the length of the working day and school year (Gidney, 1999; MacLellan, 2009).

${ }^{61}$ Reflecting on the tumultuous times in the Ontario education sector, MacLellan (2009, p.67-68) has written: "The idea of reshaping the teaching force became an important issue on the neoliberal agenda of the Harris government, and its push to promote cheaper labour (often viewed as non-certified or non-unionized), combined with greater regulatory control of tasks under strict teaching conditions were perceived to be better value for money. These policies collectively reflect a desire to minimize state obligation while maintaining or extending state control, and they have been applied to the reorganization of teachers' workplaces in Ontario, and in other jurisdictions, under slogans of quality, accountability and flexibility."
} 
sector resistance to neoliberalism, the strike sidetracked the authoritarian reforms of the Harris Conservatives, limiting some layoffs and maintaining some control over the labour process. While the strike may have been economically unsuccessful, it opened up some spaces where the public sector could play an increasingly larger role in policy debates. Both the 1996 OPSEU and 1997 teachers' strikes embody the turn to political unionism by public sector unions as the state increasingly employed the coercive use of back-to-work legislation and general authoritarianism.

\section{Consolidating Neoliberalism}

Federally, the 2000 general election returned the Liberals to power, but bitter infighting between P.M. Chretien and his former Finance Minister, Paul Martin, eventually led to the former's retirement and the acquisition of power by Martin. Through his tenure, the Martin Liberals restructured equalization payments which continued to erode real revenue transfers to the provinces (McBride and Whiteside, 2011). P.M. Martin essentially continued the assault on public services and workers by using the surpluses generated by the undermining of EI and pensions to pay down tens of millions on the deficit, as opposed to expanding the narrowing scope of EI (Scarth, 2004). By 2004, however, the "sponsorship scandal" began rocking the political fortunes of the Liberals. A report by the federal auditor general, Shelia Fraser, revealed broad corruption and misuse of public funds intended for government advertising in Quebec.

Although the Liberals were reelected to parliament with a governing minority in 2004 , the Gomery Report revealed blatant abuses of power, widespread misallocation of funds and deeply entrenched clientalism (Commission of Inquiry, 2004). The Gomery Commission found that sponsorship money was awarded to advertising firms which did little or no work for the Liberal party, and often donated part of that money back to the Liberal party. In the end, it was found that millions of dollars were effectively funneled out of public coffers into private hands or back into the bank accounts of the Liberal party (Commission of Inquiry, 2004; Kozolanka, 2006). Amid ongoing 
concerns over the extent of the Liberal party's corruption, Martin's government was defeated on a vote of non-confidence in late-November 2005. In the ensuing election, Stephen Harper's Conservatives formed government. As the next chapter will show, the election of the newly-minted Conservatives deepened the neoliberal restructuring of the state and intensified attacks against public sector workers as the case of striking museum workers and others demonstrate.

Meanwhile, in Ontario the Conservatives had become experts in combining reform bills into "massive omnibus bills that included legislation on many unrelated topics, a practice that breached the most basic liberal democratic practice of adequate notice and parliamentary debate before the people's representatives. The agenda left little or no room for public consultation and many groups were shut out of hearings on the bills." (Macdermid and Albo, 2001, p.191). ${ }^{62}$ Between 1995 and 1999 there had been 99 different tax cuts implemented by the Conservatives (Ontario Budget, 1999). Their second term in power continued along the path of neoliberalization. As a result of legislative changes implemented in the 1999 and 2000 budgets, changes to the OLRA and ESA mandated that employers in unionized workplaces post procedures for decertification, including fast-tracking decertification procedures and extending the work week to 60 hours without overtime pay. ${ }^{63}$ Between July 1994 and July 2002 direct government employment had shrunk by over 23,000 employees (Borowy, 2006). As a result of the aggressive restructuring of public sector employment which reinforced the gendered occupational segregation of administrative and clerical workers, a second round of OPSEU job actions took place in March 2002 when 45,000 Crown employees

\footnotetext{
${ }^{62}$ As a result of their majority power to push through legislative changes and expenditure reductions over the course of their first term: the Ministry of the Environment was reduced by 37 percent; the Ministry of Economic Development, Trade and Tourism by 76 percent; the Ministry of Community and Social Services by nearly 20 percent; the Ministry of Labour by 58 percent; the Management Board Secretariat by 74 percent; and the Ministry of Municipal Affairs and Housing by 73 percent (Government of Ontario, 1995-1999).

${ }^{63}$ Thomas $(2009$, p.124) has characterized the changes undertaken by the Harris' Conservatives as a return to the liberal voluntarism of the 19th century: "Combined these provisions shifted the regulation of working-time standards back to the private relations between employers and employees, and implicitly created the means for employers to exert greater control over the scheduling of work hours."
} 
struck against attempts by the Conservatives to extract further concessions under the guise of the economic recession (Panitch and Swartz, 2003).

In the middle of the strike, Finance Minister Ernie Eves had succeeded Harris as Premier, largely due to the latter's mounting public unpopularity and disapproval (Kozolanka, 2007). One of the central issues during the strike was over term-classified positions. OPSEU insisted that workers in term-classified positions should enjoy an equal measure of pay, benefits and working conditions as their permanent, full-time counterparts. Acceding to the government's plans, in the eyes of OPSEU, would only serve to further undermine the SER and weaken the efficacy of union solidarity. Although the strike lasted fifty-four days, unlike the 1996 round of bargaining, this time OPSEU was able to resist the coercion and heavy-handedness of the PC's. Although a bittersweet victory, OPSEU was able to negotiate an 8.45 percent wage hike over three years, curb the use of limited-term appointments and gain control over their own pensions (Reshef and Rastin, 2003). The relatively successful strike by OPSEU workers demonstrated the importance of fighting back against concessionary demands, even if the strike was only one small 'victory' in the span of past defeats and ongoing onslaughts. In short, OPSEU's politicization of the strike contributed to the mounting unpopularity of the Conservatives amid escalating protest movements, and crystallized the growing import of public sector political unionism. The strike also pointed to the structural constraints periodically expanding and contracting the efficacy of trade union struggles.

As argued, the PCs' tenure from 1995 to 2003 radically reoriented the province along the lines of neoliberalism. Although public sector unions and community activists, particularly those organized around the Ontario Days of Action, worked tirelessly to combat the CSR, internal fractures among the Days of Action participants, such as those between more moderate and radical labour unions and tensions among community groups and anti-capitalist activists, stymied its progression into an alternative political project leading to its eventual demise (Leach 2002; 
Goldfield and Palmer 2007). What gradually occurred through the decade is what Jenson (1986) has refereed to as the narrowing of the 'universe of political discourse'. She suggests that the space for agency and change has become all the more truncated as alternative and oppositional ideologies, identities and worldviews were marginalized from the legitimate realm of public debate. Furthermore, the inability of public sector unions to resist the cumulative pressures of federal and provincial governments exposes the limits of that resistance: on the one hand unable to transform militancy into a coherent, alternative political-economic project and, on the other, the inability to transcend the structural constraints and pressures of (neoliberal) capitalism. Given the lingering resentment toward the NDP and backlash against the Conservatives, the Liberals emerged from the 2003 election as the victors.

Under their leader, Dalton McGuinty, the Liberals ran on a platform that prioritized public sector healthcare and education, environmental protection and a tax freeze. In light of the mounting criticism of the Conservative government, especially around the shooting death of native protestor Dudley George at Ipperwash and the tainted water scandal in Walkerton (Edwards, 2001; Perkel 2002), McGuinty was able to position himself as a "moderate" becoming Premier of Ontario and gaining a Liberal majority. Centrist intimations notwithstanding, McGuinty prioritized as his first task the tackling of the $\$ 5.6$ billion deficit inherited from the PCs, indicating that his underlying orientations were in fact neoliberal. Despite modest investments in health and elder care, education, municipal transfers and social assistance, as well as annual increases to the minimum wage, these improvements still failed to repair/counteract the significant cuts enacted by Harris. Rather, these new spending initiatives barely caught up with a long history of underinvestments. As will be argued in chapter 5, McGuinty's early tenure was littered with rescinded promises that quietly consolidated and extended the earlier core of Harris' project. These include the privatization of services formerly covered under the Ontario Health Insurance Plan such as eye examinations and 
physical rehabilitation, the imposition of a staggered health premium ranging between $\$ 60$ and $\$ 900$ per year, reneging his campaign promise to close all coal-powered plants by 2007 and the weakening of the Environmental Assessment Act (Winfield, 2012). In key ways, then, this can be seen as the adaptation of a neoliberal orientation, though in a less overt form than Harris, by a government that took power by positioning itself through supposedly centrist policies.

On the labour front, McGuinty's Liberals worked to undue some but not all of the changes made to the OLRA. Under the amended provisions of the OLRA employers were no longer required to post decertification information in unionized workplaces, and remedial powers of reinstatement and automatic certification were transferred back to the OLRB. Likewise, unions were no longer required to disclose the names and salary benefits of employees earning over $\$ 100,000$ and a cardbased certification system was reinstated for the construction sector (Smith, 2009). Unlike the immediate drastic cuts and confrontations that characterized the election of Mike Harris's Conservatives, McGuinty's Liberals took a much more tactile and pragmatic approach to making changes. However, as will be discussed in chapter 5 in the case of Carleton university teaching assistants and contract instructors, while the first term of the McGuinty government was characterized by relative labour peace, the twin perils of economic recession and declining revenues gave new impetus to "opening Ontario for business" at the expense of public services and unions.

\section{Conclusion}

While neoliberal policies first asserted themselves in the late-1970s, they became a driving force through the 1980s relegating Keynesianism to the proverbial dustbin of history. Neoliberal advocates maintained that the market knows best. In their view, this required the dismantlement of the social safety net in order to create new spaces for accumulation, as well as placing constraints on unions and actively working to undermine their efficacy. The shift from Keynesianism to neoliberalism draws attention to the ongoing evolution of capitalism in its various phases and forms. 
Keynesianism was an historically unique response to then-contemporary circumstances at a point in time when the very legitimacy of capitalism was uncertain. In a similar sense, neoliberalism emerged as a class project intent on restructuring relations between labour, capital and the state. The legislative, ideological and political-economic onslaught over the period of neoliberalism undercut the important gains that trade union and social justice activists contributed to over the postwar period. In little more than a century there had been a movement away from the liberal voluntarism of the late-19th century to the modest social protections of the mid-20th century, and a (re)turn to liberal-inspired social policy at end of the 20th century. In a metaphorical sense, this long-term process of change and transition can be understood as one step forward and two steps back.

From Mulroney to Martin and Peterson to Harris, each of the governing parties sought to thoroughly embed market compulsions into the overall architecture of the public sector. From contracting-out and privatization measures to the increasing use of part-time and limited-term appointments, insecurity of job tenure had become the new norm as the standard employment relationship has been replaced by increasing forms of precarious work. Likewise, in an effort to make the public sector more like the private sector, that is, less secure and more exploitative, public sector unions have increasingly been targeted as scapegoats of so-called reform. Under the guise of economic crisis, public sector unions and social services were identified as prime targets of austerity as "essential" designations, wage freezes, layoffs and expenditure cuts expanded the terrain of capital accumulation. This was most clearly evident in the 1995 federal Liberal and Ontario Conservative budgets, which emblematically mark the point where erosion ended and demolition began. These attacks against the public provision of services and unions, however, have not been one-directional but rather cumulative with fluctuations of varying intensities.

From striking PSAC and CUPW workers to OPSEU and the Ontario teachers unions' strikes through the 1990s, public sector unions have continued to challenge unilateral managerial 
prerogatives and attacks against wages, working conditions and benefits. Often extralegal, these strikes demonstrated the importance of political unionism for public sector unions, exploding any lingering sentiments pertaining to their historical timidity. Despite the important struggles in defense of their members and broader public services, however, the cumulative effects have been to lower the expectations of workers while victories reduced to limiting the extent of concessions. This is a structural limitation which unionism alone is unable to overcome. The state-as-employer sought to not only legislate away collective bargaining rights and freedoms, but actually reinforced tendencies toward individuation through encouraging individual overtime, supporting debt and mortgages, reshaping labour law to encourage individual cases and so forth. In trying to survive in the absence of collective mechanisms, working class people had few options but to embrace such individualized solutions and so reproduced neoliberalism. Thus, the broad history of the period 1984 to 2005 can be characterized as the gradual, albeit uneven defeat of labour in the face of ongoing state and employer militancy. As the forthcoming chapter will argue, in light of the Great Recession efforts have increased to weaken unionization and privatize public assets. The aim is to turn a defeat of labour into a class defeat. A new, perhaps permanent era of austerity is on the horizon as a private sector-led economic crisis is increasingly being shifted onto the public sector. As will become evident in the case of striking Ottawa-Gatineau museum workers, and the subsequent case studies that follow, the coordinated assault on public sector services and unions have perhaps reached new heights. 


\section{Chapter 4 - Neoliberal Federalism: Ottawa-Gatineau Museum Workers and the Struggle Against Precarious Employment, 2006-2011}

This chapter is the first of three subsequent chapters examining how public services have been restructured in light of the Great Recession and increased demands for austerity. I argue that in addition to reducing the compass of social services, expenditure restraint measures have targeted unionized workers with the aim being to lower wages and reduce benefits. While each case study has its own specificity, together the cases provide fruitful terrain for developing an understanding of how long-term neoliberal policies are intensified in moments of crisis. The three case studies are linked by analysis throughout and detail how public services and public sector workers are expected to bare the burden of economic recession. While each of the unions and workers involved in the strikes under consideration have had very different historical trajectories, relationships with the state and political cultures, collectively they illuminate the variety of forms of employment and resistance by public sector unions in an unprecedented and indefinite period of austerity. Moreover, given my unique location in each of the strikes the subsequent analyses are demonstrative of intellectual work on the front lines. That is to say, they aim to overcome the distance of intellectual work by supplementing textual evidence, union documents and media reports with a first person account of the interstices of the struggles.

In this chapter I contend that Stephen Harper's Conservatives have not only consolidated the earlier set of reforms implemented by the Liberals, but that the severity and specificity of the Great Recession has served as a functional rationale for further embedding market-reinforcing policies. After discussing some of the broader public policy reforms intent on reducing the public sector's role in the economy and, by extension, broadening the space for private accumulation, I examine how the broader political-economic climate of austerity impacted collective bargaining between the Canadian Museum of Civilization Corporation, a federal Crown corporation, and PSAC Local 70396 workers. My analysis is distinct in that it draws on participant observation from the 
perspective of a student and activist. Throughout the strike I took part in picket line demonstrations, attended meetings, engaged union members in formal and informal conversations, interacted with the public through picket line demonstrations and participated in strike support solidarity initiatives. This is a unique and original contribution in that it seeks to correct failures often associated with analyses of strikes written from a distance. As a student-activist and participant-observer engaged in the strike, my analysis takes stock of particular nuances and dimensions often overlooked by journalistic and academic studies. My distinctive location in the struggle, then, provides not only a rare form of analysis placing the strike in relation to broader public policy changes, but registers the practices of the union, changes in the attitudes of striking workers and additional challenges encountered along the way. All that to say, this is a first person account of the strike, albeit from the perspective of a student-activist and participant-observer one step removed from formal participation in the strike. Although a relatively small local, insights gleaned from an analysis of how striking PSAC Local 70396 workers sought to resist demands for concessions provides a vivid portrait of public sector workplace resistance in light of a private sector-generated crisis.

\section{The Great Recession and Public Sector Retrenchment}

After thirteen years of Liberal government, public sector employment had been drastically reduced. The 1995 budget alone eliminated 29,000 positions in the federal public sector. Considering average annual growth rates of roughly 1.5 percent, or 450,000 persons, this represents a significant drop. Total federal public sector employment was smaller in 2006 than it was a decade earlier (Naczk, 2007). At the same time, the gender and educational composition of the public sector has undergone important structural changes. For instance, from 1995 to 2006 the share of women in the core public service rose from 46 to nearly 54 percent, while the share of men's employment fell from 54 to 46 percent. As with broader changes in the labour market, a university degree or higher became standard for employees working in the public sector (Beckstead and 
Vinodrai, 2003; Naczk, 2007). As a result of layoffs and leaving vacancies unfilled, the late-1990s and early-2000s led to an exodus of younger workers resulting in, on average, a much-older and largely female working staff (ibid). Previous chapters have detailed the restructuring of the public sector and the state in light of the ascendancy of neoliberalism. With the election of Stephen Harper's Conservatives, however, which coincided with the most significant and widespread recession since the 1930s, the neoliberal project found a new bearer.

Since his return to parliament in 2002 as leader of the Canadian Alliance, the successor to the Reform Party, Harper set his sights upon two of his long-term political goals: To eliminate the Liberals as a viable political alternative, as had happened in Britain, and "to make conservatism the natural government philosophy of the country." (Whittington, 2011) ${ }^{64}$ Although the Progressive Conservatives were able to moderately recover from the 1993 election they were never able to regain their broad-based appeal. Part of this stemmed from the growth of the Reform/Alliance Party which had absorbed a significant portion of socially conservative voters, which tended to split the conservative vote and sustain the Liberals in power as a result of Canada's first-past-the-post system (Martin, 2010). Another reason for the PC's inability to gain electoral traction on traditionally conservative values such as low taxes, balanced budgets, privatization and marketreinforcing policies, as previous chapters have argued, had been because of the rightward shift over the preceding decade of all political parties which ever-more embraced the ideological and policy parameters of neoliberalism. That is to say, while the political right was fractured, both the Liberals and NDP had come to - to varying degrees - endorse traditionally conservative values.

\footnotetext{
${ }^{64}$ Stephen Harper was first elected to parliament in 1993 as a Reform Party M.P. As Dobbin (1991) has argued, the Reform Party and its successor, the Canadian Alliance, were founded on western Canadian discontent and an alleged marginalization at the expense of central Canada. The Reform Party/Alliance ran on a platform emphasizing socially conservative values, individual rights and freedoms, smaller government, tax cuts, the privatization of public services and assets and the promotion of traditional "family values." As head of the National Citizens Coalition, a right-wing public advocacy association, Stephen Harper campaigned for privatizing healthcare, the Canadian Pension Plan, postsecondary education (PSE), the Canada Wheat Board, as well as an elected senate and reduced corporate and personal income taxes (Martin, 2010; Johnson, 2005).
} 
In 2006, the Stephen Harper Conservatives formed a minority government. The first years of the newly-minted Conservative government ushered in a period of small-scale, consumeroriented changes. Having inherited nearly $\$ 10$ billion surplus, the Conservatives immediately set course upon implementing neoliberal reforms. The Goods and Services tax was reduced from 7 to 6 and later 5 percent, and the National Child Care (NCC) program, an impending \$1 billion sharedcost program with the provinces, was replaced with a $\$ 1,200$ per year subsidy to children under six years of age. The replacement of the NCC with a yearly one-off bonus has been widely criticized as more costly and less effective, in addition to leaving fewer options than private sector provisioning (Bezanson, 2010). Up to this point, many of the subtle changes associated with the Conservatives had been implemented under the guise of incrementalism, small reforms less likely to scare voters than grand political changes.

By the fall of 2007, however, the Harper minority government began feeling the pressures related to a worsening economic climate. ${ }^{65}$ In contravention of their own fixed-election legislation, the Conservatives called an election alleging that parliament had become "dysfunctional" and that what was needed was a strong Conservative majority government in order to guide Canada through the economic turbulence. Although the Conservatives increased their seat total in the ensuing election, they fell 12 seats shy of majority territory. Despite Stephen Harper's contention that a majority Conservative government was necessary in order to provide "leadership and stability" in "tough economic times", the Conservatives remained bound by a minority government. But things changed rapidly as the Great Recession became a global contagion leading to a worldwide economic slump.

\footnotetext{
${ }^{65}$ The initial response by the Conservatives to a deteriorating economic climate was one of confusion and denial. In the midst of the election P.M. Harper suggested that there were some great buying opportunities in the stock market, while his Finance Minister, Jim Flaherty, insisted that Canada would not run a deficit. Six months later the deficit was estimated to be roughly $\$ 50$ billion (Laxer, 2009).
} 
What began as an unprecedented housing meltdown centered in the U.S. economy in the fall of 2007 quickly turned into a banking and financial market downturn, and later a global insolvency crisis through 2008. Due to the highly integrated nature of financial institutions and their exposure to toxic assets associated with the sub-prime housing market, including high levels of bank debt, what resulted throughout the U.S. and Europe over the course of 2007-08 was a series of forced bank mergers and quasi-nationalizations. These private sector bailouts by the public sector resulted in troubled assets being shifted onto the state sector or central banks, which also exposed other underlying problems such as increasing corporate and personal debt-loads, an overheating commercial and housing market, credit-reliant consumption, stagnant real wages and unprecedented levels of income and wealth polarization. A worldwide credit crunch soon emerged as subprime mortgage-backed securities were discovered in the portfolios of banks and hedge funds around the world. The governments of the G7 and G20 intervened with trillions to guarantee inter-bank lending and the purchasing of government and commercial paper. (McNally, 2011; Albo et al, 2010; Calinicos, 2010; Panitch et al, 2010).

In an attempt to avoid a global depression, over the fall of 2007 the G7/G20 met to coordinate the lowering of central back interest rates in order to stave off a feared turn to protectionism (McNally, 2011). Additional stimulative measures included temporary public works programs, particularly those related to infrastructure, as a means of injecting liquidity into the economy and expanding consumption. Demonstrative of the ongoing political affinity to neoliberalism, all G20 member governments agreed to further open their markets to capital, ensure credit availability and monetize public assets (ibid). Despite the most severe downturn since the Great Depression, public policy responses since the onset of the crisis confirmed neoliberalism's ongoing ideological dominance. In an unparalleled show of fiscal coordination, policy responses focused almost singularly on boosting bank and corporate profits through further tax cuts on capital, 
property and income, decreasing public sector wages, pensions and employment levels, reducing welfare expenditures, seeking union concessions and increasing user-fees backed by a massive 'monetization' (i.e. privatization) of public assets (Calinicos, 2010; Panitch et al, 2010; Georgious 2010; Lapavitsas et al 2010 ). As David McNally (2011, p.4) has argued: “...the bad bank debt that triggered the crisis in 2008 never went away - it was simply shifted onto governments. Private debt became public debt." As a consequence, it is my contention that the 2008 Great Recession provided a legitimating rationale for privatizing public services and seeking union concessions in what can be described as an indeterminate period of austerity ${ }^{66}$ With this backdrop and context in mind, the Conservatives launched a fresh round of assaults against public services and unions as the crisis unfolded.

With the onset of the crisis the federal government moved from a surplus of about $\$ 10$ billion to a deficit of $\$ 6$ billion in 2008-9 and $\$ 54$ billion for 2009-10 (Albo and Evans, 2010). While there were no major financial collapses in Canada, as there had been in the U.S. and Europe, the Harper Conservatives responded with one of the largest twin packages of stimulus and austerity (ibid). The 2008 budget removed the right to strike for federal public service workers, and limited wage increases to 2.3 percent for the first year and 1.5 percent for the remaining three years (Government of Canada, 2008). What's more, the Conservatives embarked on a series of expenditure restraint measures across the public sector in the range of five to ten percent austerity. Controversially, the government also removed pay equity adjudication from the Human Rights Commission and reinserted it into the collective bargaining process. ${ }^{67}$ In light of the financial turbulence, the 2008 and 2009 federal budgets provided liquidity support (a bail-out by another

\footnotetext{
${ }^{66}$ The International Monetary Fund, World Bank and Organization for Economic Cooperation and Development are suggesting one, and in some cases, two decades of austerity which includes, in the case of Canada for example, proposals to privatize public healthcare and education, water and electrical utilities (IMF, 2011; for a discussion see McNally, 2011).

${ }^{67}$ As PSAC (2012) has argued, such a measure undermines the established principle that human rights cannot be traded against others terms and conditions of employment or waived by agreement. The penultimate result is to deny women equity entitlements, individualize complaints and essentially bargain away pay equity.
} 
name) to the banking and financial institutions through the Insured Mortgage Purchase Program (IMPP) and Extraordinary Financing Framework (EFF) ${ }^{68}$ Despite the private-sector being the cause of the crisis, which then required public-sector dollars to 'rescue' capitalism, the federal Conservatives continue to shift the crisis onto the public sector.

The 2008 downturn set a post-war record for the most consecutive months (8) of uninterrupted decline (Cross, 2011). From October 2008 to October 2009, Canada lost 400,000 jobs as national unemployment swelled to 8.6 percent (Larochelle-Cote and Gilmore, 2009, p.5). In January 2009 alone, 129,000 job were lost - the single-greatest monthly job loss - as 5 percent of employment in manufacturing disappeared. ${ }^{69}$ Despite the significant job loses, however, the Conservative government continued along the path of austerity rather than job creation. By the end of 2008 the Conservative-led minority parliament was increasingly under strain as the Liberals, NDP and Bloc Quebecois attacked the Conservatives for their mishandling of the recession amidst mounting job losses. In an effort to stave off a potential election, the Conservatives prorogued parliament in the process silencing the people's representatives and dissenting voices all the while buying time in an effort to hold onto power (Topp, 2010).

Having resumed parliament, the 2009 federal budget included some amendments which satisfied the opposition parties thereby avoiding a vote of non-confidence. This included backing away from plans to sell-off major Crown corporations, including $\$ 40$ billion in new spending over two years, particularly on infrastructure projects, a home renovation tax credit and the extension of

\footnotetext{
${ }^{68}$ These two programs subsidized the financial industry to the tune of $\$ 275$ billion (da Silva, 2009), while giving banks and other institutions the obligation-free opportunity to auction off their potentially toxic mortgage packages to the Canada Mortgage and Housing Corporation (CMHC) in exchange for public money. Rather than allocate those funds to broad-based public services, programs and the creation of new jobs for the under- and unemployed, the government used public funds to restore the balance sheets of the financial sector.

${ }^{69}$ This intensified long-term patterns of restructuring as Canadian employment in manufacturing fell by nearly 556,000 between 2004 and 2009 (Larochelle-Cote and Gilmore, 2009, p.5). These employment losses were concentrated in permanent full-time employment, which disproportionately affected lone mothers, parents of younger children, immigrants, and those with lower levels of education who were indirectly expected to make up for decreased earnings through unpaid labour (Bernard, 2009).
} 
Employment Insurance by five weeks (Government of Canada, 2009). Personal and corporate tax cuts, however, are estimated to account for 35 percent of the total "stimulus" package; measures which, as McBride and Whiteside (2011) have reminded, are poor economic multipliers. What's more, the 2009 federal budget included measures that eased environmental regulations for oil and mining companies in the North, fast-tracked the development of Alberta oil sands projects and mandated that the provinces consider P3s in order to receive federal funding (Government of Canada, 2009). These initiatives further entrenched market mechanisms into the procurement of public projects, all the while opening up new spaces to profit-making opportunities despite the potentially catastrophic environmental consequences. ${ }^{70}$ A major point of contention in 2009 was the Canadian portion of the automotive bailouts of General Motors (G.M.) and Chrysler. ${ }^{71}$ Tossing the veil of neutrality, the federal Conservatives took an active and interventionalist approach in the public and during negotiations in order to ensure that those who bore the greatest burden of restructuring amidst corporate mismanagement where workers and the general public who paid for it twice: First, in pouring billions of public sector funds into companies with few guarantees in return and, second, in reducing wages and compensation levels (Laxer, 2009). Although allowing both G.M. and Chrysler to fail would have been irresponsible and potentially catastrophic, the

\footnotetext{
${ }^{70}$ Moreover, the 2009 budget also cut funding for equity-seeking groups such as the Status of Women, Kairos, and Rights and Democracy Watch, just to name a few. As Clancy and Brown (2010) have argued, these acts can be understood as politically motivated cutbacks aiming to cut the financial footing of groups critical to the Conservatives' agenda. In a so-called "tough on crime approach" the 2009 budget also increased mandatory minimum sentences and spending on new jails by $\$ 9$ billion. This is in conjunction with new limitations on parole opportunities and tougher sentences on youth crime, despite ample evidence indicating that tougher sentences have little, if any, deterrent effects on crime prevention (Hudson, 2003). Through the course of their terms, the Conservatives have also twice extended Canada's Afghan military mission, in addition to significant expenditures of war machinery. Clearly, these new spending initiatives suggest that austerity and retrenchment does not equally apply to all sectors (Naumetz, 2012; Brewster, 2012).

${ }^{71}$ G.M. received $\$ 7$ billion from the federal government and an additional $\$ 3.5$ billion from Ontario for an 18 percent stake in the company and a promise by G.M. to keep at least 16 percent of its North American production in Canada. At the same time, Chrysler received $\$ 1.25$ billion each from Ottawa and Ontario for a 2 percent stake in the company and a non-voting seat on the board of directors (McBride and Whiteside, 2011; Laxer 2009). In the lead up to the bailouts, both Industry Minister Clement and Finance Minister Flaherty urged the Canadian Auto Workers' union to reduce compensation expectations and make concessions (Laxer, 2009).
} 
disproportionate pressure for concessions on the part of workers, as opposed to the directors and shareholders of the companies, vividly demonstrates the disproportional burden of austerity. ${ }^{72}$

Despite the minority government, the Conservatives gradually came to exert a larger indirect role in collective bargaining with its Crown agencies and corporations. The Conservatives insisted that they would not fund increases to base salaries, therefore all government agencies and corporations, still struggling to meet the five to ten percent target of austerity enshrined in the 2008 and 2009 budgets, had to find new ways of generating 'savings'. As the impending analysis of the 2009 strike by Ottawa-Gatineau museum staff shows, workers' wages and benefits increasingly came under attack as cost-savings measures. The Canadian Museum of Civilization Corporation (CMCC) sought to make work more precarious and less secure by demanding a range of concessions. As I argue, Local 70396's efforts to resist concessions offers valuable insights for workers in their continued efforts to defend job security provisions and living wages. But it also reveals the structural constraints and, perhaps, impermanence of collective bargaining gains.

\section{Museum Workers On Strike}

After seven months of negotiations without a contract on September 21, 2009, 420 Public Service Alliance of Canada (PSAC) members with Local 70396 took job action against the Canadian Museum of Civilization Corporation's efforts to extract concessions from its workforce. The CMCC operates both the Canadian Museum of Civilization (CMC) and Canadian Museum of War (CMW), the former located in Gatineau (Hull), Quebec and the latter in Ottawa, Ontario. ${ }^{73}$

\footnotetext{
${ }^{72}$ Because nearly all Canadians are investors of some sort, whether in the form of car and student loans, pension plans, mutual funds, insurance contracts, commercial leases, bank loans and credit card debt, the accumulated deficits end up in financial markers as a direct investment or debt that is turned into an investment product. As such, allowing G.M. or Chrysler to fail could have produced widespread domino effects influencing not only Canadians' investments, but potentially jeopardizing virtually all investments around the world (see McNally, 2011 and Albo et al, 2010).

${ }^{73}$ This section draws on arguments previously published in Fanelli and Lefebvre, 2011. Local 70396 is part of the Union of National Employees, one of seventeen affiliates to the Public Service Alliance of Canada. National PSAC representatives and the Local take part in the collective bargaining process. As shown in previous chapters, PSAC has grown into one of the largest labour unions in Canada representing over 188,000 Canadian workers in the core public service, broader public sector and private sector enterprises.
} 
PSAC Local 70396 is separated into two main groups: (1) the floor staff, public hosts, tour guides, client services and animators comprise two-thirds of the membership, (2) while administration, collections and exhibition comprise the remaining one-third (PSAC, 2009a). The union is composed of approximately 60 percent women, with 5 percent from historically racialized groups, 2 percent from First Nations communities, and 6 percent persons with disabilities (R. Brassard, personal communication, October 25,2009$)$. With 92 percent of the membership voting in favour of the strike after negotiations stalled, members took to the picket lines over job security, wages and contracting-out. At the time of the strike there were only 6 permanent tour guides at both museums, while 49 positions remained temporary and part-time (ibid). As one of the striking workers stated, "This is a frightening time in which people who have full-time, permanent status still feel they could be laid off or replaced by a private firm at any time. It's incredibly difficult on the psyche" (ibid).

Using the recession as an excuse to freeze wages and contract-out employment, the strike pitted the Crown corporation against PSAC workers striking in the bordering cities of Ottawa and Gatineau. Central to the strike was the CMCC's efforts to increase the use of contractual and temporary work, which already accounted for nearly 38 percent of the workforce (ibid). As part of maintaining this level of casual employment, the CMCC regularly terminated temporary positions days before they would reach the level at which they would become eligible for a permanent position as then-stated by the collective agreement. After enforcing a three-week waiting period, the employer would unashamedly offer the former employee a new contract. The re-hired worker was then forced to start from the bottom of the pay scale without any seniority (ibid). Where layoffs and promotions were concerned, management possessed the power to terminate temporary contracts at their discretion thus making it impossible for casual workers to become permanent employees and union members. In some cases, workers with up to twenty years of experience were still considered 
temporary and could be laid-off at any time (PSAC, 2009h). An important element of the strike was significant pay differences among workers. It was not uncommon for employees in similar positions to make anywhere from twenty to forty percent less than their colleagues working at other Crown museums, despite similar levels of training, education and experience (R. Brassard, personal communication, November 3, 2009). For example, at the time of the strike a host working at the Museum of War was paid an hourly wage of $\$ 13$, while one at the Museum of Nature was paid $\$ 24$ per hour, despite similar qualifications (PSAC, 2009h). Similarly, in an effort to avoid providing benefits to its employees, the CMCC sought to extend benefit eligibility requirements for sick leave and vacation pay from a six month probationary period to twelve months. In fighting to end the unfair treatment and casualization of labour at the museums, job security, control over the labour process and wages on par with other workers at $\mathrm{CMCC}$ museums were a sticking point throughout negotiations.

Throughout the first four weeks of the strike few discussions were held between Local 70396 and the CMCC's bargaining committees. Aware of the impasse, then-Minister of Labour Rona Ambrose offered to send the labour dispute to binding arbitration. However, while PSAC was open to the idea, the CMCC refused perhaps fearful that an arbitrator would rule in the union's favour given precedent at other $\mathrm{CMCC}$ museums. Not only did the CMCC refuse to take the labour impasse to binding arbitration, but they also refused to have face-to-face meetings with Local 70396 unless their demands for job security and an end to casualization were taken off the table. After a stalemate of nine weeks, the CMCC and Local 70396 finally agreed to meet on November 20, 2009.

However, bargaining failed to provide any concrete movement as censorship and intimidation became the preferred approach of the CMCC. For instance, PSAC was presented with a letter from CMCC's legal counsel threatening that immediate action would be taken if so-called defamatory comments and photos were not deleted from a Facebook page set up to provide strike 
support entitled "Fairness and Justice for Museum Workers." PSAC responded by saying that they were not of the opinion that the material on this page was offensive or inaccurate and in turn accused the Corporation of attempting to suppress the voice of the workers who were exposing the unfair work practices and experiences they had endured (PSAC, 2009b). Maria Fitzpatrick, the Regional Executive Vice-President for the National Capital Region, described this attempt at censorship as "acts of desperation" and went on the say at the time that "we are appalled that a Crown corporation is spending taxpayers' money to attempt to intimidate workers into silence, rather than getting back to the bargaining table to negotiate a fair settlement" (Blatt, 2009).

In response, PSAC presented the CMCC with a letter of their own referring to a web publication entitled "Union Activities Counterproductive to Negotiations." In an attempt to sway public support away from the strikers, the CMCC document stated: "The Public Service Alliance of Canada and some of the strikers have taken their labour dispute from the work site to the private residences of employees of the Canadian Museum of Civilization Corporation. These employees, their spouses and children were frightened, and felt intimidated and harassed by these questionable tactics. We believe that the majority of striking staff and Canadian citizens would find such activities reprehensible and not conducive to a timely resolution of the current labour dispute". The "reprehensible" activity in question was a pancake breakfast, which PSAC describes as "in no way intimidating, frightening, harassing or otherwise improper or questionable."

With negotiations stalled, the CMCC's bargaining committee refused to address issues related to workplace insecurity, staffing procedures and wage disparities. Employing the rationale that museum workers needed to be "flexible" like their private sector counterparts, the CMCC insisted that they simply did not have the additional funds necessary to address the abovementioned workplace concerns (R. Brassard, personal communication, November 3, 2009). The CMCC did have the funds, though, to hire a private security and surveillance company to intimidate 
and continuously videotape the strikers. The $\mathrm{CMCC}$ also devoted resources to sending Records of Employment (RoE) to the homes of those on strike without explanation, perhaps sending the RoE to suggest employees would soon be out of work as part of an intimidation strategy. PSAC did not take kindly to such tactics and indicated that their lawyers would be demanding an explanation for this offense.

PSAC reassured its members that there was no legal cause for the sending out of such documents and advised them to ignore the Records of Employment. At the time, PSAC (2009b) reminded management that "Section 94 of the Canada Labour Code clearly states that no employer may terminate, layoff, discipline, transfer, suspend, intimidate, threaten or otherwise discriminate against an employee for participating in a legal strike" and threatening to do so would result in charges of unfair labour practices. Despite the corporation's unwillingness to bargain in good faith, striking PSAC workers refused to back away from their demands. Strong bonds were formed while picketing and a newfound sense of courage amongst workers left them anxious for talks to resume. Throughout, strikers stressed that the dispute was not with the public, but with the CMCC.

Unlike the resentful memory of the Ottawa public transit strike over late-2008 and early2009 (Fanelli and Paulson, 2010), striking museum workers in Gatineau and Ottawa continued to gain public support as the strike went on. Walking a picket line for weeks with no obvious end in sight can be extremely demoralizing. The financial and personal/familial strains this puts on picketers can easily fracture a common front. One useful way museum workers fought this was by putting together regular cultural events that would have normally taken place inside the museum, but holding them outside on the picket line instead. These events were open to the public and provided the workers with an opportunity to organize and work together on the picket line in a fulfilling way. The successful execution of these events, such as one honouring veterans on Remembrance Day (CBC, 2009a) and picket line tea parties held in celebration of Prince Charles's 
visit to Canada (PSAC, 2009c) contributed in a substantial way to workers' ability to maintain their spirits throughout the strike. The events also demonstrated to the public an effort on the part of workers to make the best out of a difficult situation while informing them of their issues. This was especially evident when the Museum of Civilization opened the "Afghanistan: Hidden Treasures" exhibit and workers on the picket line created their own exhibit featuring 200 photographs of museum workers engaged in strike action entitled "Striking Treasures." To quote a striking employee who worked on this project, "The purpose was to show people the real treasures of the museum... unfortunately on the sidewalk" (CBC, 2009b). Likewise, Stephanie Burchell, an actor with the CMCC's in-house theatre company Dramamuse, created a character play called Penny the Beaver who served as the unofficial mascot of the strike and whose videos were broadcast widely across Youtube, Facebook and Twitter.

Holding events such as these on the picket line made workers extremely visible to the community and showcased the skills of the striking workers and their valuable contributions to the communities which they served. It encouraged dialogue between the picketers and the public, providing an opportunity for workers to express their legitimate concerns and reasons for being on strike, as well as garnered positive media attention and political support (CBC, 2009a). Picketers were also visited by fellow artists and musicians as every bit of encouragement counted. This included the support of politicians Marcel Proulx (Member of Parliament Hull-Aylmer, Liberal Party) and Paul Dewar (Member of Parliament Ottawa-Centre, NDP), public supporters and other prominent figures such as Barry Blake (National Councilor for the Alliance of Canadian Cinema, Television and Radio Artists) and Douglas Cardinal (architect of the CMC), which provided the workers with positive reinforcement and confidence (PSAC, 2009d).

Other unions and labour affiliates also came forward in support of PSAC Local 70396, such as the Professional Institute of Public Service and the Canadian Union of Public Employees. At the 
same time, the Canadian Labour Congress (CLC) issued a statement arguing that the CMCC "has blatantly abandoned their responsibility by failing to negotiate a fair collective agreement" (CLC, 2009). The CLC also asked the CMCC, in particular its Chief Executive Officer Victor Rabinovitch, to begin a new round of talks that would put an end to the strike. Through the strike the Harper government did not directly intervene, aware that back-to-work legislation would not make it passed a Conservative minority government.

Negotiations with the CMCC finally resumed on December 11, 2009. But it took a meeting between Victor Rabinovitch, then-PSAC president John Gordon, the Deputy Minister of Labour Canada, and a Senior Official of the Federal Mediation and Conciliation Service to make it happen. In the end some important improvements to the working conditions of PSAC Local 70396 employees were won. Four improvements were central: First, the CMCC agreed to provide full-time temporary workers with the opportunity of permanent status; Second, internal applicants were granted preference to available jobs, providing they possess the necessary skills and experience; Third, new language was introduced in the collective agreement that guarantees no existing temporary position will be involuntarily eliminated as a result of the contracting out of the same position; And fourth, improvements in maternal and parental leave benefits were gained, which are now on par with the Quebec Insurance Plan. ${ }^{74}$

Also gained in negotiations were salary protections for those who are reassigned to different positions. As a step toward recognizing seniority among casual employees, the CMCC offered seven newly created permanent part-time positions filled internally based on experience and years of service. Rather than resorting to unjust terminations, the CMCC now uses attrition as a way of reducing staff numbers, while in the event of layoffs employees are offered a severance package

\footnotetext{
${ }^{74}$ The Quebec Parental Insurance Plan is perhaps the strongest in the country providing paid leave for wage-earning birth or adoptive parents. Benefits can be shared by parents or taken separately as maternal/paternal leave and include a 55-70 percent income replacement for a maximum of 18 to 37 weeks depending on the chosen option (see, for example, Bernier and Dallaire, 2001).
} 
that both the employee and the union Local must approve. Of course, there were other aspects of the strike that were not quite as successful. For instance, workers with PSAC Local 70396 were unsuccessful in their quest for wage parity with museum workers at the Museum of Nature. Likewise, after nearly three months on strike, relations with management remained strained, as do tensions between non-union and union members who crossed the picket lines. Despite these shortcomings, after 86 days on strike on December 152009 , PSAC Local 70396 workers voted to accept the tentative agreement reached with the CMCC (PSAC, 2009e).

One striking worker mused that building solidarity among the rank-and-file of the two museums and the bargaining executive played a major role in PSAC's optimism over the long haul (R. Brassard, personal communication, December 18, 2009). Tensions among the classic divide between Francophone and Anglophone workers were few, if any, perhaps due to the recognition that they were - as one striker remarked - "in this together." All union communications were issued in French and English, ensuring the free flow of necessary information. Regular updates were communicated to the membership by the negotiating team and the demands of the workers were presented in a clear and consistent way. Feelings of camaraderie were fostered within the union throughout the negotiating process. As Claire Champ, an Interpretive Planner at the Museum of Civilization quipped, "It felt incredibly empowering, being part of this collective action...It really seemed that we would be able to make change. That energy and community helped me live with uncertainty from day-to-day...It was very disorienting at first, but gradually I figured it out." (PSAC, 2010). Stephanie Burchell described it similarly: "We were all a little bit more human on the picket line. There's this illusion that we have security and stability in our lives. The strike forced us to face fear and insecurity. It was a lesson in how to be able to embrace chaos and stay grounded in uncertainty...It's fundamentally about what kind of working lives we are going to have." (ibid). Also important to striking workers was support from other PSAC Locals and unions. Indeed, some 
workers attributed the overwhelming refusal of the CMCC's "final offer" by the membership to their newfound politicization and solidarity. Strikers made clear that their resounding "no" sent a clear message to the corporation that "workers remained fiercely united, were not prepared to back down, and were to be taken seriously" (PSAC, 2009f; PSAC, 2009g). All things considered, PSAC Local 70396 embodied a form of unionism that went beyond immediate workplace demands. They embraced a form of unionism that came to understand collective bargaining as an equally important political process, one that stretched beyond limited economic issues and extended into the community.

Even though the strike led to a four-year agreement with minor pay increases, some job security provisions and improvements to parental leave, fears of increased private sector penetration at the CMCC continues to loom large. For instance, shortly after the strike then-CEO of the CMCC Victor Rabinovitch stated that he intended to focus his energies on "attracting private sector support to supplement government funding", including potentially privatizing various souvenir shops (CMCC, 2009). Throughout the strike, it was evident that the orthodoxy of neoliberalism played a broader, looming role throughout negotiations. Pressures to adopt concessions, lower wages, decrease benefits and increase the use of contractual and part-time work, while resisted, nevertheless remain present. Moreover, having gained a majority legislature in parliament, the Conservatives are now free to legislate-away collective bargaining rights and freedoms, and impose austerity on workers without the fear of opposition parties blocking such actions. As a result, the union is already preparing for what they perceive will be an extremely difficult round of bargaining come the end of 2013. 


\section{From Minority to Majority Government}

Through 2010 the Harper Conservatives continued to implement expenditure restraint measures, with little concern for either the revenue side of the equation or the most costly expenditures on management outsourcing. ${ }^{75}$ It is plain to see the deep-seated influence of New Public Management philosophies on the Harper government. This has been particularly evident in their cult-like emphasis on using private sector agencies to find so-called "efficiencies" in the public sector. From 2005-6 to 2009-10, the costs of personnel outsourcing of temporary help, information and technology, and management consultants has risen from $\$ 660$ million to $\$ 1.2$ billion (Macdonald, 2011, p.8). Additionally, while the amount bid to win outsourcing contracts has decreased, the final cost of outsourced contracts has often ballooned to many times its original bid. Although there are literally hundreds of IT, management and accounting firms specializing in outsourcing, upwards of 40 percent of all outsourcing contracts were awarded to just ten companies suggesting a tightly-knit and disproportionately concentrated awardence of contracts. ${ }^{76}$ Because these private firms are not held to the same merit and transparency standards of officially employed public sector employees, they are often immune from access to information requests. And because these are private firms, employees are often paid lower wages with fewer benefits and prohibited from unionizing (ibid).

The 2010 federal budget sought to cut another $\$ 17.6$ billion over five years through operating and administrative reductions (Government of Canada Budget, 2010). This is on top of four previous strategic reviews and a personnel expenditure freeze since the Conservatives have

\footnotetext{
${ }^{75}$ For the second time in less than a year, Stephen Harper requested the prorogation of parliament. From December 30 , 2009 to March 3, 2010 parliament did not sit. While P.M. Stephen Harper maintained that such action was necessary not to 'put at risk Canada's fragile economic recovery', detractors have suggested that such a move was politically motivated so as to prevent ongoing scrutiny over the transfer of Afghan prisoners and Canada's knowledge about alleged abusive treatment (Martin, 2010).

${ }^{76}$ In an example of low-bidding with higher returns, in 2009-2010, an IT consulting company was paid more than three and one-half times more than their original bid. Likewise, in another case, a management firm was hired to work for two months at the cost of $\$ 29,000$, but their contract was extended to three years and ended up costing over $\$ 243,000$ (Macdonald, 2009).
} 
been in office, which is expected to cut $\$ 7.82$ billion by 2014-15 (Macdonald, 2012, p.10). As part of the 2011 budget, the Harper Conservatives hired management consultant firm Deloitte Inc. for $\$ 19.8$ million (or nearly $\$ 90,000$ per day) to advise senior and elected officials on ways to improve productivity and efficiency in the public sector (Government of Canada, 2011). While information indicating exactly where such cuts are to fall remain difficult to come by, it is expected that the federal public sector will shed upwards of 6,000 full-time positions, while reducing salary and benefit costs, departmental operating budgets and, in the process, transferring funding from nonprofit and Crown corporations to the private, for-profit sector (Macdonald, 2012). ${ }^{77}$

On March 25, 2011, Stephan Harper's Conservative government was found in contempt of parliament for their refusal to share information with parliamentarians on the transfer of Afghan prisoners. ${ }^{78}$ The non-confidence motion triggered the fourth election in seven years. On May 2, 2011 the Harper Conservatives gained the majority they had long sought after, while the historic breakthrough of the NDP catapulted them to the Official Opposition (Fidler, 2011). Not having to worry about legislation making it through parliament, the Conservatives immediately began flexing their majority muscles with the immediate use of back-to-work legislation.

After seven months of negotiations without a contract on June 2, 2011, nearly 50,000 workers at the Canada Post Corporation (CPC) took job action against the employer's attempts to reduce wages, benefits and working conditions. Rather than launching a full-out strike, the

\footnotetext{
${ }^{77}$ As will be explored in chapter 7, in light of the Conservatives' "open for business" approach to industry, the federal tax-to-GDP ratio dropped to its lowest since 1961. Corporate taxes have fallen from 28.5 percent in 2000 to 21 percent in 2004, 19.5 percent in 2008 and 15 percent in 2012, the lowest in all of the G7 (Evans and Albo, 2010). Just twelve years ago the average combined federal/provincial tax was 43.6 percent, and the Conservatives have been clear to the provinces that they want this down to 25 percent. All told, tax cuts enacted since 2006 will be equal to $\$ 220$ billion in forgone revenue by 2013-14 (Whittington, 2011). That is money that could have gone toward expanding and improving healthcare and education, pension plans, early learning and child care programs, tackling poverty and fighting climate change. The class dimensions of state restructuring are clear as the Conservatives seek to reduce corporate and income taxes in an effort to fuel capital accumulation.

${ }^{78}$ It is not without irony that during his time at Opposition Leader, Harper remarked: "Information in the lifeblood of a democracy. Without adequate access to key information about government policies and programs, citizens and parliamentarians cannot make informed decisions, and incompetent or corrupt governance can be hidden under a cloak of secrecy." (Martin, 2010, p.254).
} 
Canadian Union of Postal Workers (CUPW) decided on rotating job actions, while continuing to deliver pension and social assistance cheques. Canada Post's intentions were unambiguous: introduce new machinery and workplace reorganization in an effort to intensify productivity; increase the volume of mail carried by each letter carrier; cut well-paying, full-time positions; introduce more evening and overnight shift work; replace sick leave rights with an inferior Short Term Disability Plan; and, most contentiously, introduce a lower pay scale and replace the definedbenefit pension plan with a defined-contribution plan (Camfield, 2011b). After twelve days of rotating job actions on June 14, 2011 the CPC locked-out its workers. One-day later Labour Minister Lisa Raitt tabled back-to-work legislation, vowing not to put at risk "Canada's fragile economic recovery," imposing a wage scale that was lower than the CPC's last offer (CTV, 2011). ${ }^{79}$

But, as David Camfield (2011b) has written, that wasn't the worst part:

\begin{abstract}
"The law dictates that the new collective agreement for urban postal workers will be determined by an arbitrator appointed unilaterally by the Minister of Labour, using a method called final offer selection (FOS). FOS is uncommon in Canada, and is very rare in back to work legislation. In this case, the union and the employer are each required to submit a final offer covering the many disputed issues. The arbitrator will then select one offer or the other in its entirety. In addition to allowing the Conservatives to handpick whoever they want as the arbitrator, the law includes guidelines that the arbitrator must follow in choosing a settlement...This puts intense pressure on CUPW officials to submit a final offer that includes concessions they would never have agreed to in bargaining, in the hope that the arbitrator will pick their offer rather than an even-worse one from the employer."
\end{abstract}

CUPW challenged the appointment of the first arbitrator, retired judge Coulter Osbourne, on the grounds that he was unilingual and had no previous labour experience. A federal court agreed with CUPW's objections removing judge Osbourne as arbitrator (CNW, 2012). Next, Minister of Labour Lisa Raiit appointed former Conservative MP candidate Guy Dufort. Fearful that the arbitrator would be more inclined to legislate government policy rather than serve as an arbiter, CUPW challenged the appointment of Dufort in court. Dufort refused to remove himself despite his past partisan activities. Once again, a federal court sided with CUPW removing Dufort as arbitrator

\footnotetext{
${ }^{79}$ Subsequent research by Steinhoff and Bickerton (2012) have demonstrated that the strike had a negligible, if minor, impact on the Canadian economy as a whole.
} 
(CUPW, 2012). Finally, on October 5 2012, the two sides reached an agreement without the intervention of an arbitrator. By this point, the Conservatives had made a mockery of free collective bargaining by not only enacting back-to-work legislation, but using FOS and the selection of a partisan arbitrator to circumvent the entire process. The agreement introduces two-tier wages as well as a hybrid pension plan that combines a defined-contribution and defined-benefit plan (Callaghan, 2012). Although CUPW has historically been one of the most militant and radicalized unions in the Canadian labour movement, known for their "no-concessions bargaining", the concessions on their part raise important questions about the structural limitations of collective bargaining and the ability to resist concessionary demands in light of overwhelming state coercion. Moreover, the actions on the part of the Harper Conservatives demonstrate a flagrant interference in free collective bargaining as they deploy the heavy-handedness of the state to "resolve" disputes.

Like Canada Post workers, on June 14, 2011, 3,800 call-centre staff and check-in workers unionized with the Canadian Automobile Workers (CAW) at Air Canada took job action against the company's attempts to reduce wages, benefits and working conditions. Air Canada management sought to implement a two-tiered wage system, increase the minimum retirement age by five years and, like the CPC, impose a defined-contribution pension plan over the much more secure definedbenefit plan. A private company, unlike the CPC, it must be recalled that for the majority of Air Canada's rank and file workers, wages had been cut and frozen in 2003 amidst bankruptcy proceedings (CBC, 2003; Adelaide, 2003). However, while demanding that workers reduce compensation levels, Air Canada executive pay continued to balloon. For example, CEO Calin Rovinescu's pay rose from $\$ 2.6$ million in 2009 to more than $\$ 4.5$ million in 2010 (Sorenson, 2012). Their is a blatant contradiction in employers' demands for wage and benefit concessions, while increasing the pay and benefits of its most highly compensated managerial personnel. 
Just two hours into the strike Labour Minister Lisa Raitt, once again vowed not to put at risk "Canada's fragile economic recovery," motioned that she would be tabling back-to-work legislation (Kane, 2011). With the threat of back-to-work legislation looming large, Air Canada and the CAW were able to reach an agreement soon after the Minster of Labour tabled legislation forcing strikers back-to-work. The new agreement includes a nine percent wage increase over four years, reestablishes a 30-minute paid lunch break and limits the use of part-time labour with guaranteed full-time positions at Chorus (formerly Jazz Air). However, binding arbitration resulted in the creation of a dual-structure pension plan that sees new customer service agents have a mixed defined-benefit and defined-contribution plan, while existing employees continue to have a definedbenefit plan (Lu, 2011; Freeman, 2011). Both CUPW and CAW members, like their PSAC counterparts, worked tirelessly to resist concessions. But all three, to varying degrees, had to deal with aggressive employers -implicitly and explicitly via state involvement - that tried to use the recession as an excuse to squeeze more "efficiency" out of their workers. The end result of this was to dilute and weaken free collective bargaining by shifting the costs of the crisis onto the public sector. Finally, all three unions also had to deal with varying degrees of concessions, despite minor improvements elsewhere, chipping-away at hard won gains during previous rounds of collective bargaining. The case studies examined here demonstrate the increasingly authoritarian tendencies of the federal state in undermining the right to strike and bargain collectively. The newfound aggressiveness of the Harper Conservatives owing to their majority power in employing the coercive mechanism of back-to-work legislation signals what is likely a disturbing precedent for future collective bargaining. 


\section{Conclusion}

Using the economic recession as a political justification, the Harper government has sought to institute privatization measures, layoffs, reductions to social services and circumvent free collective bargaining. There is a barefaced contradiction in the present demands from employers for concessions from private and public sector workers: the economic crisis has been generated by the inefficiencies and reckless excesses of capital, but it is being demanded that workers pay for the crisis while public funds are being deployed to bail-out banks and private companies. The utilization of the current economic crisis by governments and big business is a conscious strategy that aims to make long-term gains for capital in its control over labour and to continue to tip the balance of class power toward capital. Despite the deepest and most pronounced downturn since the 1930 s, the prescribed cure is more of the same malady - that is, more free-markets, more competition, less regulatory oversight, less labour protections, and ongoing attacks against the provision of public sector services and unions. In a nutshell, more neoliberal capitalism.

The government of Stephen Harper has responded to the Great Recession with a combination of corporate tax cuts, outsourcing, wage freezes and an adversarial approach to collective bargaining. Nearly all of the alleged savings and efficiency measures come at the expense of intensified workplace practices, increased precarity of job tenure, lower wages and reduced services. This must be seen as an explicitly class project disproportionately targeting the public sector and relying on force and compulsion to do so. While striking PSAC workers in Local 70396 were certainly not, on the whole, anti-capitalist in their aims and efforts, their forms of protest and public engagement went a long way in connecting with the broader community and making the linkages between public services, workers and those who rely on those services. This included, as outlined above, generalizing their specific qualms into broader social issues, connecting with the general public, seeking to break down the arbitrary distinction between public and private sector 
workers, challenging the division of labour within the employment structure, communicating with their members and the public in a clear and consistent manner, and confronting management prerogatives. As workers learned and struggled together confidence and optimism became contagious among members. As PSAC Local 70396 members showed, fighting back matters, although the threat of future concessions remains present.

CUPW and CAW workers, however, were immediately legislated back-to-work. Using the recession as an excuse, the Harper Conservatives chose to remove the collective bargaining rights of workers in order to maintain the balance sheets of corporations. What's more, they took an active and interventionalist approach to compel reductions to overall compensation and discipline workers to market forces. This raises important concerns about the structural and legal constraints which unions are unable to transcend. In short, although unions fought back they could not match up against the consolidated power of capital and the state. 


\section{Chapter 5 - Ontario and the Public Sector Squeeze: CUPE 4600 and Collective Bargaining at Carleton University, 2006-2011}

In this chapter I argue that the governing Liberals have consolidated and extended the neoliberal project brought to the fore with the election of the Harris Conservatives. Rather than depart from the market-led revamping of the public sector, the McGuinty Liberals have quietly and sometimes through more dramatic ruptures embedded core neoliberal policies into the overall architecture of public policy. This includes tax shifting for competitiveness, public sector wage repression and the retrenchment of public services. While the first four years of the Liberals' mandate was characterized by relative labour peace, this was not due to a new consensual and collaborative relationship between public sector unions and the government but the result of the historically specific macro-economic and political circumstances of the time. The relative labour peace also signified the political realignment of labour, embodied in the shift to the Liberals, expressing trade unions' adaptations to the authoritarian conditions of neoliberalism.

In what follows, I contend that as the tailwinds of the Great Recession made themselves felt on Ontario, the Liberal government of Dalton McGuinty responded in a thoroughly neoliberal manner calling for a decade of austerity. The major policy plank of this program was the Open Ontario Plan, which called for: tax relief, a wage freeze for public sector workers, the privatization of public assets, innovation corridors to promote hyper-competitive trade liberalization, and regressive reforms to employment standards legislation. This squeeze on the public sector was further amplified through less than genuine consultative negotiations between the government and unions over 2010. I make the case that the recessionary budgets of the Ontario Liberal government sought to trade wage and benefit concessions against the protection of public services. This dynamic served to stifle free collective bargaining by using the recession as an excuse to extract concessions all the while extending forms of corporate welfare. 
My thesis is demonstrated by the Carleton University administration's claim that there hands were tied in negotiations with CUPE Local 4600. Despite reduced public transfers and the gradual privatization of post-secondary education in Ontario since the late-1980s, the Liberals maintained that they would not be funding any net compensation increases related to collective bargaining costs at Ontario Universities. In the case of Carleton University, the administration sought to implement a wage freeze and, in the process, put into practice a host of surveillance, speed-up and disciplinary measures. My analysis is based on my experiences as a graduate student and teaching assistant at Carleton University. It is informed by my experiences as a CUPE 4600 member and provides a unique scholarly analysis of trade union organizing based on participant observation from the perspective of a student, activist and worker. Throughout the strike I took part in membership meetings, leafleting campaigns, solidarity support meetings, open forums and membership outreach initiatives.

As a student, worker and activist my study takes stock of particular nuances and dimensions often overlooked by studies examining larger unions, particularly those that go on strike. My unique location in the struggle, then, provides not only an original contribution placing it in relation to broader public policy changes, but documents the practices of the union, extent of concessionary demands and outcome of negotiations. Therefore, my investigation is original in that seeks to supplement the limitations of analysis written from a distance. Secondary literature, such as academic and journalistic articles, are used to complement my account of the major issues involved in collective bargaining. The strategies and tactics of CUPE Local 4600 in the run up and during negotiations provides a useful case study from which broader generalizations pertaining to collective bargaining may be gleaned in light of the unique circumstances generated by an unprecedented era of austerity. All things considered, the Liberal austerity offensive, despite the 
absence of direct confrontations over this period, may signal what is likely a prelude to a future legislative intervention.

\section{Ontario Responds to the Great Recession: The Open Ontario Plan}

As argued in chapter 3, the McGuinty Liberals ran on a platform emphasizing the importance of public investments in education, healthcare and social services - public expenditures which, taken together, account for more than two-thirds of provincial operating costs. This was in part because from 1998 to 2003, through a combination of corporate and other income tax reductions, the governing Conservatives eliminated nearly $\$ 62$ billion from public revenues (Evans, 2007). Given the backlash against the Progressive Conservatives and lingering resentment over the New Democratic government of Bob Rae, Dalton McGuinty's Liberals established themselves as a "Third Way" centrist party without the heavy historical baggage of its two main rivals (Evans, 2011). As part of this continued resentment toward the historic party of labour in Canada, the NDP, major private and public sector unions in the run-up to the 2003 election explicitly campaigned against the PC's while implicitly supporting the Liberals through arbiter groups like the Working Families Coalition (Walchuck, 2010; Savage, 2008). Offering both financial support and third party campaigning, this shift toward Liberal support symbolized the political realignment of labour in Ontario. For Evans (2011), this shift was symptomatic of an ideological divide expressing trade unions' adaptations to the conditions of neoliberalism in turning to defensive strategies and tactics. It also signaled the start of a cozy relationship between labour and the Liberals but one which, as will be argued, was perhaps merely the calm before the storm. Rather than move away from the Common Sense Revolution as some have suggested (Gattinger and Saint-Pierre, 2010), the Liberals 
consolidated the neoliberal project in a tactile and incrementalist manner that contrasted with the explicit attacks against public services, unionized workers and the welfare state more broadly. ${ }^{80}$

As argued, the prioritization of the $\$ 5.6$ billion deficit inherited from the PCs indicated that the Liberals' underlying orientations were in fact neoliberal. The CSR's fiscal orthodoxy and fidelity to balanced budgets remained the major policy plank from which the Liberals anchored their priorities. Through 2003 the Liberals maintained that "corporate taxes are already competitive" and that proceeding with additional cuts would "compromise our ability to make investments that increase our productivity." (Evans, 2011, p.176). Rather than undoing or mitigating a broad spectrum of personal and corporate tax cuts to address the budget shortfall, however, the Liberals left them in place looking to find efficiencies in the delivery of services and reducing the budgets of non-priority spending in the hopes of gaining from a renewed bout of economic growth. Through their first term the Liberals emphasized that there was a necessary trade-off between protecting public services and union restraint at the bargaining table (Evans, 2011). New spending initiatives in healthcare, education and social services still failed to catch up with or repair more than a decade of underinvestments in social and physical infrastructure (CCPA, 2007). Modest savings were made through the privatization of services formerly covered by the Ontario Health Insurance Plan like physical rehabilitation and eye exams, and new user costs added to the delivery of medical services (Government of Ontario, 2004; 2005). Unlike the immediate drastic cuts and confrontations that characterized the tenure of the Harris Conservatives, McGuinty's Liberals operated in a much less provocative and subtler fashion

\footnotetext{
${ }^{80}$ As Evans (2011, p.176) has argued: "It certainly was a departure from the open class warfare of the Harrisite Common Sense Revolution, but any suggestion that the arrival of the Liberals marked a rupture from neoliberalism is entirely based on a few redistributive measures, modest reinvestments in public services and certain labour law reforms that improved but didn't fully roll back the Harris government's reform of labour policy (Bartikiw, 2010)."
} 
Elected to a second mandate in 2007, McGuinty's campaign benefited from PC leader John Tory's highly controversial plan to extend public funding to faith-based schools. ${ }^{81}$ The NDP failed to galvanize public support with a platform premised on holding the line on MPP pay, tax breaks for the "everyday" worker and a plan for modest investments in public services. Absent was any notion of its earlier proposals for public auto insurance, wealth and inheritance taxes or any fundamental challenge to big business or the neoliberal paradigm. McGuinty's 2007 election marked the first time in 70 years that the Liberals have been able to secure back-to-back victories in Ontario since 1937. Throughout McGuinty's terms, he has shown himself to be a much more sophisticated and nuanced neoliberal than his predecessors. By reversing some (but not all) of the labour market reforms made by Harris, introducing new public management techniques in health care via P3s to build hospitals and the introduction of Local Health Integrated Networks to rationalize the health system along market pressures, including a focus on supply-side labour market responses to unemployment through Second Career/retraining (Armstrong 2001; Loxley 2010), McGuinty's Liberals have shown themselves much more comfortable veering between stringent neoliberal orthodoxy and political opportunism.

For instance, while the Liberals were reducing public services and flat-lining public sector workers' pay, counter-measures included the raising of the minimum wage over several years after taking power and investments in the automotive industry (CCPA, 2007; Evans, 2011) ${ }^{82}$ But as the tailwinds of the Great Recession increasingly made themselves felt in Canada, and in particular Ontario, the not-so-distant memories of the CSR suddenly reappeared in new form. While the McGuinty government implemented some emergency measures, such as $\$ 4.6$ billion in short-term infrastructure spending, $\$ 2.2$ billion in new post-secondary education and liquidity support for G.M.

\footnotetext{
${ }^{81}$ This section draws on arguments previously published in Fanelli and Thomas, 2011

${ }^{82}$ In 2010 the minimum wage was subsequently frozen at $\$ 10.25$. McGuinty justified this act by citing the need to help "employers", as opposed to employees, "get back on their feet." (Toronto Star, 2011).
} 
and Chrysler, these measures were hardly Keynesian in their stimulative effects (Ontario Budget, 2009; 2010). Instead, these measures were part and parcel neoliberal as they were matched by tax shifting for competitiveness, wage repression and the retrenchment of public sector services. In other words, as the Great Recession increasingly made itself felt in Ontario, the Liberal government of Dalton McGuinty responded with a thoroughly neoliberal budget seeking to shift the burden of crisis off the private sector and onto the public sector.

With an expected budget shortfall of $\$ 18.7$ billion for $2009-10$, $\$ 21.1$ billion for 2010-11 and \$19.4 billion in 2011-12, and deficits expected to continue until 2017-18, a number of measures were proposed in the 2009 spring budget to reestablish balanced-budgets (Government of Ontario, 2009). ${ }^{83}$ The government clearly signaled its intention to embrace neoliberal austerity measures in Finance Minister Dwight Duncan's budget speech on March 8, 2010 during which he introduced the Open Ontario Plan (OOP) (Ontario 2010a). In both name and policies, the Plan signaled a new era of austerity in the course of reorganizing neoliberalism to assert its legitimacy as both political philosophy and policy orientation. In seeking to entrench the ideological legitimacy of neoliberalism and, therewith, ensure that the brunt of bailing out capitalism (and neoliberalism) is borne by the working class, the Ontario government undertook a broad program of austerity. In May 2010, the government introduced the Open for Business Act as a key component of this plan. The OBA was part of a much larger government initiative to create a climate favourable for business investment in the province, with the government claiming it would do this while simultaneously protecting the environment and the broader public interest (Ontario Ministry of Labour 2010a). The wide ranging Act, with over 100 proposed amendments to various pieces of legislation, included provisions to establish a "modern, risk-based" approach to environmental approvals, as well as new

\footnotetext{
${ }^{83}$ Ontario is not alone among the Canadian provinces in facing unprecedented deficits. In 2009 the ten provinces collectively ran the largest deficits in Canadian history at $\$ 48.2$ billion. From British Columbia to Newfoundland and Labrador each of the provinces have imposed varying degrees of public sector austerity, however, there has been a subsequent lag in research examining its consequences (Evans and Albo, 2010).
} 
procedures to enable "efficient resolution" of employment standards claims. The Act also included amendments to facilitate easier access for some foreign trained professionals to employment in Ontario. The government framed the OBA as legislation that would promote new and transparent relationships between business and government, while also providing protections in areas such as environment and employment. Sandra Pupatello, Ontario Minister of Economic Development and Trade, described the Act as follows:

Our government is committed to helping businesses focus on what they do best - creating jobs for Ontario families. We can protect the public interest without creating unnecessary barriers to business. The OBA will save businesses both time and money (ibid).

Clearly, the articulation suggested here implies that "modern" government ought to enhance (rather than impede) "competitiveness", while the seemingly neutral chimera of "prosperity" obscures the class dimensions of the public interest. The frame of "modernization" is not new however; it was a catchword of Harris-era employment standards reforms as well, when Harris' government "modernized" employment standards by introducing a 60-hour work week, freezing the minimum wage, and allowing for the averaging of overtime hours so as to undermine overtime premium rates (Thomas 2009).

Ontario's business community was clearly in favour of the kinds of deregulatory measures found in the OBA. ${ }^{84}$ Elyse Allan, President and CEO of General Electric Canada, offered the following:

\footnotetext{
"I applaud the government's move to reduce business costs by streamlining regulations and harmonizing them with other jurisdictions where possible. The reforms in the procedure for environmental Certificates of Approval, for example, could bring significant benefits to $\mathrm{GE}$ and other companies. With regulatory simplification and recent changes in the tax structure, the Ontario government has taken important steps to make Ontario an attractive place for companies to invest and create jobs" (Ontario Ministry of Labour 2010b).
}

\footnotetext{
${ }^{84}$ Len Crispino, President \& CEO of the Ontario Chamber of Commerce, claimed: "Concrete measures to reduce red tape in Ontario are long overdue, particularly in the areas of labour and environment. Improvements will allow our members to spend more of their money advancing productivity and creating jobs, both of which are vitally important for Ontario's prosperity, rather than dealing with onerous and sometimes contradictory regulations." (Ontario Ministry of Labour 2010a).
} 
The OOP emphasizes five central courses of action: (1) tax relief; (2) a wage freeze for public sector employees; (3) privatization of public assets; (4) the development of "innovation corridors" to promote inter-provincial trade; and (5) reforms to "modernize" employment standards legislation. First, the government of Ontario lowered the general Corporate Income Tax (CIT) rate from 14 to 12 percent, with plans to reduce it to 10 percent by 2013-14. This also included the lowering of the CIT for manufacturing and processing from 12 to 10 percent, while small businesses saw the CIT cut from 5.5 to 4.5 percent and the small-business deduction surtax eliminated. This will make Ontario's CIT among the lowest in the OECD (Ontario Budget, 2010). The Corporate Minimum Tax was reduced from 4 to 2.7 percent in 2010, with more small and medium-sized businesses now made exempt. Likewise, the Capital Tax has been completely eliminated. This was a small surcharge of 0.3 percent on the first $\$ 400$ million of taxable capital, 0.54 percent for non-deposit taking financial institutions with taxable capital over $\$ 400$ million and 0.67 percent on deposit taking financial institutions with over $\$ 400,000$ million in taxable capital. This translates into a $\$ 500,000$ million per year public subsidy for some of Canada's largest corporations. Following suit, personal income tax cuts have also been enacted. For instance, the tax rate on the first $\$ 37,106$ of taxable income has been reduced by more than 16 percent, from 6.05 percent to 5.05 percent, while those earning up to $\$ 80,000$ per year saw a tax cut of 10 percent (Government of Ontario, 2010).

All in all, following the full phase-in of Ontario's comprehensive tax reforms, the marginal effective tax rate, which measures the tax burden on new business investment, will be cut in half by 2018. As such, businesses will be subsidized by $\$ 4.6$ billion from tax cuts on income and capital over the next three years under the guise of stimulating "competitiveness" and attracting new investment. In total, the aggregate revenue loss as a consequence of the Liberals broad program of tax cuts in the 2010 budget is equal to $\$ 18$ billion in lost revenue (Mackenzie, 2010). Additionally, 
nearly $\$ 2$ billion will be lost by the government owing to cost overruns at public-privatepartnerships, most notably at E-Health and ORNGE (OMF 2010a/b; CBC, 2009c; Cohn, 2012). However, while personal income tax cuts have a broad populist appeal, such forms of corporate welfare and tax reductions, as will be argued in chapter 7 , have been shown to have a negligible impact on job creation or economic growth. Instead, as subsequent research has shown, the supposed link between low taxation of corporations and increased job creation is over simplistic and largely untrue (Loxley, 2010; Whittington and Delacourt, 2011).

Second, on March 25, 2010 the Ontario government enacted the Public Sector Compensation To Protect Public Services Act. Affecting roughly 16 percent of Ontario's workforce, the Act imposed a two-year wage freeze for 350,000 non-unionized public sector workers, while also indirectly affecting 710,000 unionized public sector workers that are being asked to take a "voluntary" two-year wage freeze. Premier McGuinty and Finance Minister Duncan have forcefully insisted that their government will not fund net compensation increases to operational costs associated with collective agreements. As I argue in the case study that follows, the government's program of austerity had both explicit and implicit implications as workers at Carleton University sought to reach a new collective agreement. The Liberals indirectly stifled free collective bargaining by making wage and benefit gains dependent on a renewed bout of economic growth using the rationale that public services depended on moderating wages (i.e. a wage freeze) which, given inflation, actually translated into a pay cut. ${ }^{85}$ After the two year freeze, wage increases will be governed by the province's 1.9 percent cap on expenditure growth. Both McGuinty and Duncan have consistently reiterated that they are not ruling anything out when it comes to

\footnotetext{
${ }^{85}$ Despite the proposed freeze, an arbitration decision by Norm Jesin awarded 17,000 workers in long-term care homes a 2 percent wage increase for 2010. In his ruling, Arbitrator Jesin said that employers and labour leaders must respond to economic decisions, not a government's fiscal policy, in setting wages (Benzie and Ferguson 2010). In a similar ruling, Arbitrator Martin Teplitsky, defying the Liberal's proposed wage freeze, awarded University of Toronto faculty and librarians a 4.5 percent wage increase over two years. Refusing to appear a "minion of government" and "compromise my independence", Teplitsky noted his ruling echoes average private sector wage hikes at 2.3 percent over the year in Ontario (Brown 2010).
} 
legislating austerity, wage freezes or furloughs (Ferguson and Benzie 2009). Equally important, McGuinty urged Ontario municipalities to follow their lead, suggesting he could impose a five percent target of austerity on cities (Benzie and Maloney 2010). Such measures will allegedly "save" the government $\$ 750$ million over two years. As I argue in chapter 6 , though, in suggesting that Ontario's 139,000 municipal workers make a "sacrifice" and share in the burden of austerity, opportunistic mayors and councilors throughout Ontario and in particular Toronto have used this as a rationale to reduce services and seek concessions form its workforce.

The Ontario Ministry of Finance, echoing McGuinty and Duncan, have frequently reiterated the need for "everyone who is paid through taxpayer dollars to do their part" (Ontario Ministry of Finance, 2011). But, of course, not only does compensation restraint not extend to the private sector, it excludes those most generously remunerated by public tax dollars. ${ }^{86}$ Instead, the restraint act targets public sector works, in particular women (due to persisting gendered pay differentials) and racialized groups (as a result of race-based wage disparities), which earn substantially less than those most generously remunerated by public sector dollars. Moreover, it must be noted that average public sector wages in Ontario did not return to their real 1992 levels until 2008, a return the restraint act undermines by freezing pay and thereby restarting a dynamic that will once again contribute to the deterioration of public sector wages (McCarthy et al., 2010).

Third, the Ontario government is contemplating the massive privatization of public goods and assets in order to pay down its deficit (Benzie 2010). McGuinty's Liberals recently paid $\$ 200,000$ to CIBC World Markets and Goldman Sachs to create a white paper proposing the creation of "SuperCorp." The idea behind the mega-corporation would be to combine Ontario's

\footnotetext{
${ }^{86}$ The restraint measures exclude public sector managers and CEOs who are still entitled to "performance-related" pay and bonuses, which often make up the bulk of their compensation. This means, for instance, that CEOs in public sector organizations, often migrants from the private sector, are not included such as Hydro One President and CEO Laura Formusa ( $\$ 975,000$ per year) and Ontario Power Generation CEO Tom Mitchell ( $\$ 1$ million per annum). And neither are corporations heavily dependent upon public sector contracts, such as P3s or for-profit companies like Extendicare and its CEO Tim Lukenda ( $\$ 1.5$ million in yearly total compensation) (Ontario Ministry of Finance, 2010b).
} 
Crown assets, including nuclear power plants, power generation facilities, 29,000 kilometers of electrical transmission and distribution lines, six-hundred plus liquor stores and gaming operations, in order to package and sell it off piece by piece. By ceding fiduciary control the government alleges the $\$ 60$ billion worth in assets could be put to better use by private investors, while the windfall gains used to pay down the deficit (ibid). However, one-time fiscal injections are hardly a remedy for chronic under-funding and systemic undermining. While the government continues to mull this over, the selling of Crown assets has been put on hold in order to deal with the politically sensitive and expedient task of freezing wages and reducing service level provisions.

Fourth, the provincial government is engaged in the development of "innovation corridors" to promote inter-provincial trade and investment. The Ontario-Quebec Trade and Cooperation Agreement quietly signed between the provinces on September 112009 , extends previous agreements and is "designed to increase investment and trade between Ontario and Quebec, promote innovation and reduce long-standing barriers to business" (Economic Development and Trade 2011; Quebec-Ontario Trade and Cooperation Agreement 2009). As the fourth largest economic zone in North America, the explicit aim is to create a common economic space, including precedent-setting chapters on financial services, energy, transportation and regulatory cooperation, in order to compete against the next largest geo-economic zones (New York, California and Texas) and rising opponents (e.g. the Maritimes and western provinces). With a combined Gross Domestic Product of over $\$ 800,000$ billion in 2007 , and cross-border trade valued at over $\$ 70$ billion in 2004 , the Agreement is unambiguous in its efforts to "liberalize trade and...enhance economic integration." Furthermore, the Ontario-Quebec Continental Gateway and Trade Corridor strategy aims to focus on the development of the region's high-technology, infrastructure, agriculture and manufacturing industries, as well as tourism and multimodal transportation systems that aim to improve the flow of exports to the US and other trade partners. Central to this Agreement is the 
push for further opening and integrating markets, increasing labour productivity and enhancing competition between and within jurisdictions. Moreover, like the North American Free Trade Agreement, the Ontario-Quebec agreement seeks to open up the public procurement of contracts by instituting a reciprocal non-discrimination clause that mandates the $\mathrm{P} 3$ route. Such an investor-state dispute mechanism, as is most visible in NAFTA's Chapter 11, essentially cedes democratic control and decision-making processes away from local communities and toward business interests that could sue any tier of government should they impinge upon their "right" to profit (Johnson and Mahon, 2005).

Finally, the OBA contains a series of measures designed to "modernize" employment standards legislation in Ontario. As part of the OOP, Bill 68 replicates Alberta's and BC's "selfhelp" model for complaints and enforcement pertaining to the Ontario Employment Standards Act. Under the proposed changes, an employee would need to address the issues directly with their employer in advance of government intervention (Ontario 2010b). In turn, the employer must respond directly to the employee within a certain period of time. Should the employer fail to respond within a certain time frame, the Ministry of Labour would seek a response on behalf of the employee. In other words, employees are expected to make all "reasonable efforts" to resolve the dispute individually on a case-by-case basis. ${ }^{87}$ The Bill would mandate workers to first confront the employer before filing a complaint regarding owed back-pay, wrongful dismissal, harassment, vacation and overtime. When the "self-help" system was introduced in BC in 2002, employment standards complaints from workers dropped 46 percent (ibid). While the government may attribute the drop in reports to improved dispute resolution mechanisms, given the extreme power

\footnotetext{
${ }^{87}$ In an article in the Toronto Star, construction worker Raul Aguilera, describing his battle for unpaid wages against one of his former employers in BC, poses it thus: "How would you feel if you got robbed but couldn't report to the police unless you had first confronted the robber and asked for your money back?" (Keung 2010).
} 
imbalances in capitalist workplaces, a much more likely explanation is that the drop reflects the unwillingness of workers to confront their employer for fear of retribution.

The "modern" employment standards of the OBA also place responsibility on individual workers to collect the information for their complaints and allowing Employment Standards Officers the ability to make decisions "on the best information available", thereby reducing expectations for a more rigorous and proactive inspections process (Ontario 2010c). If an officer determines that there is insufficient evidence provided by an employee, then the officer may determine there is no violation. Officers are also given a new role in negotiating a mediated settlement (Ontario 2010d). The implications of this amendment to the ESA are twofold. First, it promotes voluntarism by creating the potential for employers to resist the process if they feel it will not work in their favour. Second, it privileges a mediated settlement over an actual award, which may expedite the claims process but could reduce the value of the settlement achieved by a worker. Regardless of the outcome of individual settlements, this orientation represents a transformation in the role of ES officers from those who make judgments based on fact-finding to mediators in a process that assumes two equal parties, when in fact the parties are far from equal. ${ }^{88}$

According to the Ontario Ministry of Labour, the aim of ES modernization is to "establish services that achieve fairness for workers, while helping business to be increasingly competitive in the global economy" (Ontario 2010c). The assumption behind the changes to the employment standards complaints procedures is that "[m]ost employers want to do the right thing and they will often remedy the situation promptly and voluntarily, if they agree there is a valid claim" (Ontario 2010c). However, the new reforms to the ESA emphasize an individualized, privatized, and

\footnotetext{
${ }^{88}$ In addition to the OBA, the Ministry of Labour struck an Employment Standards Task Force to address the backlog of 14,000 accumulated ES complaints and has given the Task Force a two-year mandate. The Task Force will investigate these claims through reviews of written evidence and telephone discussions, and in some cases in-person meetings (Ontario, 2010c.). The new complaints procedures that place onus on complainants to provide evidence of ES violations will shape the process as "officers will make decisions on the available evidence" (ibid). Additionally, the Task Force will utilize the new emphasis on voluntary, mediated settlements as a means to resolve claims and to create a more efficient process (ibid).
} 
voluntary process for regulating ES complaints and settlements. Building on a decades-long legacy of ineffective employment standards regulation, the OBA entrenches an individualized, complaintbased enforcement model that is likely to heighten conditions of labour market insecurity at a time of growing economic polarization.

An equally insidious sixth measure might be added. Over the spring and summer of 2010, major private and public sector unions were invited by the government to participate in a consultations process finding ways to increase efficiency and streamline public sector compensation growth in the form of a two-year wage freeze. This process shares similarities with the measures undertaken by the Rae NDP government in their "negotiations" with public sector unions just prior to their legislative implementation in the form of the "social contract", although negotiations did not follow a similar end. Consultations began on August 9 and continued to October 3 and were broken down into three phases with three tables (Evans, 2011). The meetings included representatives from the Service Employees International Union, Canadian Autoworkers, Ontario Public Service Employees Union, Canadian Union of Public Employees, Ontario Nurses Association, as well as some localized university faculty associations and other unions representing professionals such as lawyers, engineers, doctors, scientists and policy analysts. The purpose of the consultations was to develop, under the guise of negotiation, a "framework agreement" that could be implemented locally. Some unions refused to participate in the process all together, while some participated minimally and others tried to engage fully (ibid).

But what actually transpired were far from substantive negotiations as the Liberals refused to entertain any new forms of revenue generation such as the reversal of tax cuts or changes in management structures as a way to save funds. Instead, as Evans (2011, p.175) has made clear: "And here is the zero sum of the government's strategy: that protection of public services was contingent upon an effective wage cut for public sector workers." In other words, without strong 
economic growth and hence increased revenue generation, public services and public sector workers' compensation were in jeopardy. Had the government been open to an array of expenditure restraint measures that did not disproportionately single out public sector unions and included truly negotiable outcomes, such as new taxes on corporations or a financial transactions tax, perhaps the sectoral and class dimensions would have appeared as more neutral. But these so-called negotiations signaled nothing other than the first shot across the bow in what is a deepening project of austerity. Even worse, for Evans (2011), the whole process was limited by its lack of diversity in union representation, and was nothing more than a political tactic and public policy exercise by the government, which signaled that the axe would soon be dropping as a prelude to future legislative intervention in light of recent Supreme Court decisions. ${ }^{89}$

The negotiations of the McGuinty government with private and public sector unions suggest their preference of using carrots to the stick. But there was very little, if anything, to actually go around. Rather, the insincere meetings painted the Liberals - relentlessly propagated at speeches and rallies - as the responsible, even paternalistic, overseer of the public purse. The consultations also suggested to businesses and the public that, despite their cozy relationship with public sector unions, the Liberals were getting ready to be tough on them if supposedly sound economic thinking did not prevail. It is important to note that over the period 2004 to 2009, wage growth for the public sector as a whole was 18.8 percent, largely due to revenue growth that averaged 8.7 percent yearly from 2003-2008. This is in comparison with private sector compensation growth of only 13.7 percent over the same period (Evans, 2001, p. 179). Rather than using the pay differential to illustrate the unwillingness of private capital to share in productivity growth and hence profits, in

${ }^{89}$ Evans is referring to the 2007 Supreme Court decision in Health Services and Support-Facilities Subsector Bargaining Assn v. British Columbia. As Savage (2009, p.15) has argued, the "decision makes clear that governments have a duty to bargain in good faith, [but] there is little to stop a determined antiunion employer from rolling back trade union rights and freedoms in existing collective agreements, provided such rollbacks come at the conclusion of a process of consultation with the union. That is because it is the process, not the outcome of bargaining, that is protected by the charter." Thus, the consultation exercise by the Liberals seems to have been less concerned with reaching a negotiated framework than with checking "did consultation" off the charter-proofing checklist (Evans, 2011). 
addition to often inferior working conditions and benefits, a joint-study by the accounting firm KPMG and the University of Toronto's Mowat Centre for Policy Innovation, reflecting their advocation of neoliberal and NPM-inspired reforms, made the case that: "Bringing down the cost of wages and benefits in the broad public sector may be good public policy because it furthers equity objectives." (Mowat-KPMG, 2010, p.22). The neoliberal public policy exercise in seeking to redefine the crisis as stemming from a bloated and inefficient public sector is reflected in the report which goes on to add that the public sector should get out of providing services where it could be done cheaper and more efficiently in the private sector, thereby delivering savings and reducing the escalating costs of wages and benefits. In a nutshell, absent from the report is any indictment of private sector volatility which led to the Great Recession, the inferior working conditions and growing precarity of job tenure in the private sector or the growing disparities of income and wealth as a consequence of this "race to the bottom." The belief that reducing wages and benefits in the public sector as an "equity objective" is a perverse sense of logic wide-ranging in its presumptuous and ahistoricity. The recommendation merely parrots neoliberalism's most vocal and dogmatic expositors.

Moreover, in times of economic insecurity demands for public services grow as workers seek to cushion the blows of decreased revenue and unemployment by relying on the services that their tax dollars support. Ironically however, it is those very services - what remains of the social safety net - that is under attack as the burden of the crisis is shifted onto the public sector and the working class as a whole. With wages consuming just over 50 percent of total expenditure costs in the public sector, the Liberals used the superior pay and working conditions of public sector workers as a wedge strategy to garner union resentment. The pay differential, however, stems not from overgenerous social services and inflated union wages, but is a consequence of the highlyskilled services workers provide accompanied by a recognition by unions that public sector workers 
should lead with decent working conditions and fair remuneration, rather than follow the often inferior, insecure and exploitative conditions of the private sector.

Despite this, the OOP forecasts austerity extending to 2017-18, when the budget will purportedly be balanced. Should this happen, as Evans and Albo (2010) show, this will result in a 20 percent contraction of Ontario's public sector economy (from 19.2 percent of GDP to 15.5 percent), thereby reducing the public sector's share to levels corresponding to the period of Harris's Common Sense Revolution. Perversely, these measures have not slowed representatives from the business community from arguing that Canada's labour laws are "too restrictive." ${ }^{.90}$ It is clear, therefore, that despite the crisis generated by the reckless excesses of capital, its most passionate proponents, as will be argued in chapter 7 , are emerging emboldened and on the offensive amid the lack of a sustained political fight-back from organized labour. Employing the rationale that public sector workers have been proverbially sheltered from the recession, the Liberals' program of austerity has targeted wages, benefits and working conditions in the public sector. In what follows, I demonstrate how the austere Open Ontario Plan implicitly stifled free collective bargaining at Carleton University. I contend that the OOP, placed within the broader historical trajectory of the Liberals' time in government, signals an enhanced period of looming confrontation. The OOP, then, can be seen as testing the waters before, perhaps, the ultimate stick of legislation is used to curtail public sector wages and social services spending. As this round of bargaining between Carleton University and CUPE 4600 demonstrates, the employer sought to use the recession and the Ontario austerity agenda as a justification for extracting concessions from its workers and increasing userfees. While this case study is limited to one round of bargaining and one union, it demonstrates the interstices of trade union struggles in resisting concessions amid a deepening program of austerity.

\footnotetext{
${ }^{90}$ Seizing a ripe political opportunity, Catherine Swift of the Canadian Federation of Independent Businesses used the week of Labour Day 2010 to argue, "When it comes to forcing workers to join a union and pay dues, Canada increasingly stands alone on this" (CFIB 2010). This is a thinly veiled effort to restart talks aimed at undoing the Rand Formula, the definitive element of Canada's postwar settlement labour legislation.
} 


\section{PSE Reform and Marketization: At the Crossroads of Student and Worker}

Unlike the case of striking museum workers at Ottawa-Gatineau explored in the previous chapter, the members of CUPE 4600 tend to occupy a dual-space, so to say, as most often full-time students and part-time workers. In some cases, members are part-time students and full-time workers and, in others, recent graduates thus contractually limited as full- or part-time workers. Thus CUPE 4600 members are at the crossroads of a student-worker nexus, which cannot be separated from (a) changes specific to the education and employment conditions at Carleton University and (b) also broader changes to both public spending and policy decisions effecting postsecondary education (PSE). CUPE 4600 is composed of two units: Unit 1 includes approximately 1,800 teaching and research assistants and Unit 2 is composed of roughly 450 contract instructors across the university. Before describing the process leading up to negotiations and the challenges encountered along the way, it is necessary to first briefly explore the background and context of post-secondary education (PSE) restructuring in Ontario over the period of neoliberalism because CUPE 4600 workers' relationship as students cannot be separated from their paid-employment.

It is my contention that over the period of neoliberalism, consecutive governments at the federal and provincial spheres increasingly sought to "modernize" PSE by restructuring it along "competitive" market pressures (Hursh, 2006; Servage, 2009). In this sense, education is envisaged as a commodity to be bought and sold like any other, while the market is presumed to effectively (i.e. profitably) allocate scarce resources ${ }^{91}$ Unfortunately, many Canadian universities have been steadily emulating the American model of privatized post-secondary education (Giroux and Myrsiades, 2001; Servage, 2009). The user-fee model, which assumes private, post-graduation returns by charging up-front fees borrowed against expected future earnings, as others have argued,

\footnotetext{
91 For example, approaching $\$ 3$ trillion in market "opportunities" a 1999 report by Merrill Lynch identifies the educational sector as a major source of untapped privatization. As "performance-based" evaluations become more prevalent testing and assessment niche markets are also expected to grow between 10 and 15 percent annually (Albert, 2002).
} 
has shown itself to be a fundamentally flawed model for post-secondary education characterized by inequitable access, persisting student debts, precarity of job tenure and widespread private-sector penetration (Marsh, 2011; Hill, 2009; Biddle, 2001). In Canada, this signifies a considerable movement away from a publicly funded post-secondary education system financed through progressive taxes, which have been shown to increase equitability, enhance working conditions, decrease debt loads and provide a measure of insulation against corporate directed research and study (Aronowitz, 2000; Giroux and Myrsiades, 2001).

In order to cope with chronic underfunding, many universities and colleges are turning to part-time instructors rather than full-time, tenured faculty, resulting in an increased rate of precarious employment as well as reduced student-professor face-time. For neoliberal proponents “...knowledge [is viewed] as a commodity...and education as a path to income generation that must be privatized and made profitable in order for it to be maintained effectively." (Caffentzis, 2005, p.600). Increasingly, then, democratic control over resources, knowledge production and public space is monopolized by private interests with no other aim but to make a profit. ${ }^{92}$ Hence, many universities are streamlining their services and course offerings to those that address market considerations or are "business-related", while those more critically inclined, and therefore less likely to buy into a purely market driven educational model are isolated or have their program spending reduced or axed all together. This includes smaller departments and/or programs such as women's and cultural studies, history and philosophy, critical interdisciplinary centres, especially those focused on labour-capital relations and smaller specialized programs like political economy or Canadian studies (Donoghue, 2008).

\footnotetext{
${ }^{92}$ A prominent example of this at Carleton is the attempted introduction of NAVITAS, a for-profit multinational educational corporation that charges (especially international) students exorbitant fees while setting up shop at publicly funded institutions by renting space, using the university name and logo in promotional materials, hiring non-unionized staff, appropriating intellectual property and offering an unaccountable commodity disguised as university education. Unfortunately, such agreements increasingly form a part of Canadian Universities' strategy of marketizing education with a focus on corporate branding campaigns premised on business-related programs (CUPE, 2011).
} 
As such, neoliberal governments increasingly recede from maintaining investments in arts, humanities and the social sciences at a rate that is marginally comparable to the physical sciences or market-directed research (Lynch, 2006). Rather, university presidents and administrators navigate the grant economy seeking to partner with private sector funders, in the process endangering scholastic independence by catering to the needs of powerful sectoral interests (Servage, 2009; Dylan, 2012). This necessarily "curtails the pedagogic processes that potentially generates a critical perspective against the [capitalist] system..." (Kumar, 2010, n.p.). More to the point, "Education is more than formal institutional structures and classroom transactions. It is an arena that reflects the agenda and need of the dominant class interests in a society. Therefore, to understand whatever happens in education it is important to understand the class politics, or labour-capital conflict, characterizing a society." (ibid). In this sense, the terrain of education and what is taught is at its core a field of class struggle. Issues of accessibility, social justice, knowledge production and, central to this study, trade union organizing in the PSE sector are themselves deeply rooted political and class issues.

Therefore, it is important to emphasize the historical influence that consecutive reductions from federal governments in terms of loans, scholarships and transfers over the course of neoliberalism have had on the provinces (Servage, 2009; Hyslop-Margison and Leonard, 2012). In Ontario, between 1988-9 and 2005-6 consecutive federal governments have reduced total transfer (both cash and tax points) payments for PSE by 40 percent (in 1998 dollars), while simultaneously pushing for enhanced partnerships with business counterparts in order to create new profit-making oppotunities (Fisher et al.2008, p. 553). This translated into the "de-regulation" and liberalization of Ontario's PSE fees and thereby the creation of a quasi-market in the public sector (Fisher et al., 2006, 2008; Jones and Young, 2004). This is perhaps best reflected in the steadily advancing privatization of PSE in Ontario as there has been a proliferation of private career colleges opened 
since the 1990s as commercial enterprises. The number of these colleges rose from just over 200 in 1990 to over 450 by 2004 (Fisher et al., 2008; Levin, Kater, and Wagoner, 2006 ). In Ontario, between 1992-3 and 2004-5 provincial expenditures on PSE (in 2004 dollars) decreased by nearly 15 percent (Fisher et al. 2008, p. 553). Transfers to colleges and Universities per full-time equivalent student enrollment over the same period decreased by nearly 32 percent (CAUT, 2006).

Thus PSE user-fees and hence privatization measures are subtly being introduced under a policy framework of incrementalism. ${ }^{93}$ In Ontario, spending as a share of university operating revenue between 1994 and 2004 decreased from 73 to 49 percent (Fisher et al. 2008, p. 554). While in 1990 tuition fees accounted for 20 percent of institutional operating budgets, today it's over 50 percent. As a consequence, between 1991 and 2008 average domestic tuition fees across Canada increased by 176 percent (Carleton GSA, 2010-11). It is useful to point out that approximately 40 percent of the Canadian population lives in Ontario and roughly 42 percent of Canadians choose Ontario as their destination for PSE. Thus what happens to PSE and labour disputes in Ontario may reveal broader trends Canada-wide (Jones and Young, 2004; Servage, 2009; Dylan, 2012). Ontario occupies the unenviable distinction as the most expensive province in the country to complete an undergraduate degree. In 1990 the average cost of Canadian tuition was under $\$ 1,500$ but now stands at more than $\$ 6,000$ per year. This mirrors a similar process for graduate students who now have to pay the highest fees in the country at roughly $\$ 8,500$ per year (Carleton GSA, 2010-11). ${ }^{94}$ The tuition fee freeze that students won between 2004 and 2006 was cancelled by the Liberal

\footnotetext{
93 Although, there have been no clear indications from the Ontario government suggesting an explicit expansion of forprofit PSE, recent discussion papers suggest they are quickly moving in that direction (MTCU, 2012; Commission, 2012;). The Council of Ontario Universities (2012) and Ontario College and University Faculty Association (2012) have come out sharply against the reports.

${ }^{94}$ This pales in comparison with Quebec's average undergraduate cost of $\$ 2,415$, which have been frozen for thirty-five years. It must be recalled that Quebec never passed the cost of federal funding cuts onto students, while college also remains free for residents and scholarships are 'needs-based' in an effort to reduce socio-economic inequalities. Similarly, between 2002-04, the government of Newfoundland and Labrador reduced tuition fees by 25 per cent and have since then been frozen (although austerity measures may undermine the freeze, and the Quebec differential) (Sears, 2012).
} 
government and replaced with a tuition framework that allows for increases of between 5 and 8 percent per year until 2012. As a result, Ontario undergraduate students hold the largest debt at graduation averaging $\$ 37,000$ per student and increasing to $\$ 43,700$ for $\mathrm{PhD}$ graduates (ibid). At $\$ 9,718$ average per-student funding, Ontario spends 20 per cent less than the national average of $\$ 12,500$ leading to larger class sizes and debt overhangs that have resulted in the number of summer days a student would have to work to make enough money to pay tuition fees for one year rising from barely over six weeks in 1980 to fifteen weeks by $2010^{95}$. As well, Ontario continues to provide zero funding transfers to universities for foreign students. This has not stopped many university administrations from seeing international (particularly graduate) students as a strong source of foreign capital since they pay upwards of three times what domestic students pay (ibid). ${ }^{96}$

All things considered, the trajectory of PSE in Ontario is one where higher education is envisaged as serving business-related vocational and technical labour market needs, sustaining competition and ensuring market-oriented research. ${ }^{97}$ Thus recent austerity measures must be considered in historical perspective as budget cuts and the pressures related to collective bargaining are merely the latest in a sustained assault on public universities and public services more broadly. In what follows, I explore on how the Great Recession and the McGuinty government's turn to austerity impacted collective bargaining rights at Carleton University. I argue that the economic crisis served as a political pretext stifling free collective bargaining as the university sought to increase the scope of precarious work as a means of deceptive cost-savings. Because members of CUPE 4600 are often at the nexus of a student-worker relationship, it is important to keep in mind

\footnotetext{
${ }_{95}$ Based on undergraduate fees averaging \$5,951, minimum wage and an 8-hour work day (Carleton GSA, 2010-11).

${ }^{96}$ Despite the increasing debt loads, the VP of Finance at Carleton University, Duncan Watt, peddled such a view when he declared: "If we could find a way of actually attracting graduate students and paying them less money, that would be a very good thing for us." (Watt, 2010). Tuition is projected to rise by another 31.5 percent over the next six years. Watt seems to be suggesting that university cost-savings and funding for students are mutually incompatible and that one necessarily takes away from the other, rather than seeing the two as mutually constitutive.

${ }^{97}$ Some have argued that the University of Ontario Institute of Technology - the first new university in the province in forty years - is explicitly oriented to serving the automotive, technological and electrical power generation industries in Ontario (Fisher et al, 2008).
} 
the historical changes discussed above in the PSE sector as they continue to influence issues related to compensation and workplace restructuring. In other words, the retrenchment of PSE funding cannot be separated from Carleton University workers as sellers as their labour power and most often students.

\section{CUPE 4600 and Collective Bargaining at Carleton University}

In the run up to collective bargaining between the administration and CUPE 4600, some 25 locals in the university sector as a whole (representing both academic and non-academic staff) had collective agreements expire between March 31 and August 31, 2010. ${ }^{98}$ Through CUPE Ontario, bargaining units in the university sector were invited to sign on to a resolution developed by the Ontario University Workers Coordinating Committee (CUPE-OUWCC, 2010). The resolution advocated that Locals at the bargaining table in 2010 and 2011 commit to no concession bargaining and coordinate bargaining proposals. This included discussing the appropriateness of flat-rate wage increases, improving benefit and pension plans, employment equity and job security as well as collective agreement language on eliminating harassment in the workplace.

Of the seven proposals contained in the OUWCC resolution, two are of particular importance for this study (CUPE-OUWCC, 2010). The first was committing to negotiating new wage and compensation packages in spite of the Liberal government's desire to impose a wage freeze. The second was encouraging Locals to sign three-year collective agreements. The goal in the former was to ensure that public sector workers are not the ones who must singularly pay for a crisis generated by the private sector. In the case of the latter, encouraging locals to sign on to three-year agreements was one method of ensuring that coordinated bargaining could continue and that university Locals could more effectively support and contribute to the struggles at other universities.

\footnotetext{
${ }^{98}$ This section draws on arguments previously published in Fanelli and Meades, 2011.
} 
In addition to CUPE 4600, two other CUPE Locals had collective agreements expire between April 31 and August 31, 2010: (1) Local 2424 representing support and administrative staff and the (2) faculty workers Carleton University Academic Staff Association (CUASA). A fourth CUPE Local's (910, representing physical plant workers) agreement was set to expire at the end of the year. All in all, then, Carleton's four central unions were essentially bargaining at the same time. This created the ideal circumstances - at least on the surface - for coordinated pressure. As one way to develop and enhance the cooperation of the different units, the four union Locals joined with both the undergraduate and graduate student associations in a loose alliance called Campus United. Together, various participants attempted to develop a proactive support system through which activities and resolutions could be coordinated. The meetings also provided a space where bargaining strategies, tactics, messaging and due process could be openly discussed and developed. Weekly inter-union meetings allowed representatives to keep their own memberships informed and afforded the opportunity to see what issues could be harnessed together for the purposes of collective bargaining. However, it soon became apparent that there was a big difference between bargaining together and bargaining collectively. As Gindin and Stanford (2006, p. 382) have reminded: “...we must nevertheless recognize that apparent unity never automatically implies active solidarity."

Despite what were very productive and helpful meetings over the summer and into the Fall term, several key issues interrupting the closer integration of collective bargaining strategies emerged. The most immediate were the differences between workers who held positions as permanent careers, most often CUPE Locals 2424, 910 and CUASA, and those that held positions as temporary jobs either as a source of graduate school funding or as workers in part-time teaching positions as in the case of CUPE 4600 . In other words, on the one hand were the faculty, support staff and physical plant workers with careers and a long-term investment in the Carleton community 
and, on the other, were the graduate students/teaching assistants and contract instructors who held fewer job protections and were accompanied by a set deadline for the completion of employment as stipulated in their offer of admission.

As collective discussions among the CUPE Locals progressed, it became apparent that each of the unions faced their own internal issues that affected the extent to which a coordinated bargaining strategy could be developed such as issues related to the terms of employment, job conditions, the legality of solidarity strikes and the forethought of potentially having to cross picket lines. Likewise, an additional barrier to overcome were differences among union members who were more concerned about their own or their union's concerns than about cross-campus labour solidarity. While there was certainly strong coordination between the unions in terms of sharing information, holding joint information events and cost-sharing, procedural issues filing no-board reports hampered the coordination of a solidaristic bargaining front. Because each of the unions' legal strike dates fell on different days, the pressure to reach an agreement with the university differed, leading to the fracturing of a collective bargaining strategy as each Local essentially went about it on their own terms. What transpired was that, first, CUASA, and later CUPE Local 2424, each reached tentative agreements. This left CUPE Local 4600, perhaps the most precarious amalgam of workers at the university owning to their location as students (or recent graduates) and part-time workers isolated without their most valuable workplace allies.

The other noticeable issue affecting coordination between the different union Locals was in part historical. ${ }^{99}$ CUPE Local 4600 also faced a number of its own internal challenges. The largest and most apparent was learning from the mistakes from the 2008 round of bargaining in which members voted against a strike mandate. In the absence of a strike mandate, the ensuing round of

\footnotetext{
${ }^{99}$ In 2007, CUPE Local 2424 had gone on strike for 18 days. With lingering anxieties as to the potential for another strike, including tensions related to other unions on campus crossing their picket lines (despite some members coming out to engage in solidarity picket duty), the bitter aftertaste from the 2007 round of bargaining remained fresh on the minds of many.
} 
bargaining resulted in the loss of fixed tuition indexation, which eroded the take-home pay of CUPE 4600 members given their intersection as students and workers. ${ }^{100}$ This round of bargaining also took place against the backdrop of York University's widely publicized 2008-09 strike action that ended in debacle for both the university and the union, including back-to-work legislation, as well as local pressures in Ottawa related to striking transportation workers (Newstadt, 2008; Fanelli and Paulson, 2010). All that to say, this created an historical environment that was less than conducive to union gains at the bargaining table, let alone a strong strike mandate.

For the 2010 round of bargaining, an additional challenge was mobilizing the membership, including the influx of several hundred new members in the form of new graduate students. In this regard, several different strategies were employed. CUPE 4600 played an active organizational role in welcoming new students during the graduate student association's orientation week events. As well, the Local hosted a "meet your union" night that offered members the opportunity to socialize in a relaxed environment and ask questions in person. There was also an effort to ensure at least one union executive member was present at each departmental TA orientation session to inform new members about their rights and responsibilities under the collective agreement, as well as to encourage them to get involved in their union's activities. In addition to mobilizing new members, it was equally important to retain and encourage existing union members to get involved as best they could. Further, the union executive sought to ensure that wider communication and outreach strategies reflected key concerns at the bargaining table in such a way that would appeal not only to the membership but also to the wider community. In other words, CUPE 4600 at public and membership meetings sought to make the connection between publically-funded education and paid-employment, a long history of deteriorating public investments and corporate tax reductions.

\footnotetext{
${ }^{100}$ There have been no detailed case studies of previous rounds of bargaining. Fixed tuition indexation protected TA's from increases in tuition by fixing it to a particular year regardless of when the TA began their employment. With the lost strike vote, there is now a system of rolling tuition indexation wherein tuition is fixed to the first year of employment.
} 
The union sought to demonstrate to workers and the general public at large that workplace issues cannot be isolated independently but must be seem as part of broader public policy measures and the state's relationship with the private sector. CUPE 4600 also tabled information sessions on campus and participated on local radio shows where listeners could call-in their questions. In light of the union's very public dialogue and efforts to engage the broader Carleton community, this led some to declare that CUPE 4600 had won the public relations campaign (Roberts, 2010).

Having run a strong mobilization and communication campaign in the run up to collective bargaining, members of the respective bargaining teams focused on moving talks along at the bargaining table. However, despite the impending expiration of the contract, representatives of the university were unable to meet CUPE 4600 requests to begin negotiations over the summer, citing that they did not have a bargaining team together and that the necessary people were away for summer vacation. In an effort to press the university to begin the collective bargaining process well in advance, CUPE 4600 filed for conciliation in mid-August in order to compel the employer to sit down at the bargaining table. However, despite the pressure to begin bargaining, the first exchange of proposals did not take place until late-September. Six issues were central to this round of bargaining: (1) Carleton University administration's refusal to budge on a wage freeze; (2) the administration's attempt to include a new article in the collective agreement that would force graduate students to receive permission from their supervisor before they were eligible to apply to teach a course; (3) the university's unwillingness to entertain minimum health benefits for contract instructors; (4) the administration's refusal to place a cap on TA-to-student ratios; (5) attempts to include new language in the collective agreement that would allow the administration to not renew the contracts of instructors that received two consecutive weak teaching evaluations, which also included efforts to include formal TA evaluations in the use of hiring; and (6) the administration's efforts to increase from 17 to 25 percent the percentage of instructor appointments without a job 
competition. Despite the delays and, in the eyes of CUPE 4600, a purposeful tactic designed to first come to agreements with the other unions on campus, by early-October regular meetings were being held between CUPE 4600 representatives and representatives of the university.

However, as CUPE 4600 moved closer to a legal strike deadline, the university administration began taking preemptive measures in the event of a strike which led to a questioning of the administration's underlying motives. Under the guise of fulfilling their obligations to students, the university's contingency plan, sent to all Deans and Associate Deans on November 14th, 2010, stated that "it is essential that the university have available all of the information that it requires to complete its mission even if some employees are on strike." ${ }^{101}$ Meaning that, "all documents, files, computer records, e-mail and voicemail that are part of the university's work must be accessible by appropriate supervisors and managers." Further, the contingency plan requested that all departmental chairs and directors collect from TAs and contract instructors, "(i) all ungraded work (ii) all graded but unreturned work and (iii) all interim term grades...well before the first legal strike date." For CUPE 4600 such anticipatory measures, "well before the first legal strike date", raised questions about the university's sincerity in seeking to reach an agreement. In fact, as some members alleged at membership meetings, it was felt that the university was purposefully goading the union into strike action in order to achieve their desired ends.

In the eyes of the union, the first obstacle in resisting the Liberals' public sector wage freeze at Carleton University was to convince CUPE 4600 members that such a move by the employer constituted a serious threat to working conditions and take-home pay. It was argued at membership meetings that should the union choose to accept a wage freeze this would open the door to endless concessions and potentially a two-tier wage structure. Furthermore, because rent, inflation, food and

\footnotetext{
101 This is taken from an email entitled "Employee Rights and Responsibilities in the Event of a Strike" sent by the Vice-President Finance and Administration, Duncan Watt, on November 18th to all members of CUPE 4600 just four days prior to the legal strike deadline.
} 
public transportation had increased between 7 and 20 percent between 2003 and 2009 accepting a wage freeze would significantly undercut the real value of workers' take-home pay (Statistics Canada, 2008). Because minor increases in pay are one of the few ways that students/workers can try to keep up with inflation convincing the membership to grant a strike mandate proved less difficult than the previous round of bargaining - 74 percent of TA's and 89 percent of contract instructors voted in favour. As members argued at membership meetings, the challenge for CUPE 4600 was to bargain from a position of strength using the strong strike mandate and community's support as leverage.

When the topic of wage increases was broached during the initial bargaining sessions, the employer responded that their hands were tied by the province and the Board of Governors and that they could not move from the province's directive of zero percent over the next two years. This was unacceptable for CUPE 4600, especially since it was then revealed that tuition fees would be rising, on average, 4.5 percent each year between 2011 and 2017. The union pressed the university's bargaining team to return to the Board of Governors and obtain a new mandate. ${ }^{102}$ Despite the evidence and data presented by CUPE 4600 that demonstrated increasing university revenues, largely due to increased enrollment and tuition costs, the university did not change their tune of austerity.

It was not until the strike deadline was approaching that movement began from the employer on wages and other issues. At first discussions over a wage increase were hypothetical, then came efforts to entice the union into instead accepting a one-time signing bonus. It was only when there was less than one week before the strike deadline that the employer began seriously tabling wage increases and backing off other concessionary demands. CUPE 4600 s insistence on wage increases

\footnotetext{
102 One of the most difficult aspects of bargaining in the university sector is the fact that the people who sit across the bargaining table are not necessarily the ones who make final decisions. The bargaining mandate is developed by a special executive council from the Board of Governors, which leaves the representatives for the university with little final decision making power.
} 
stemmed in part from the tentative settlement reached with CUPE 2424, which saw increases of 1.5 percent over the first two years and 2 percent in the third and fourth years of the contract. On November 20th, just two days before CUPE 4600s legal strike deadline, the university offered a 1.5 percent wage increase over the first two years of the contract and 2 percent increase in the third year for Unit 1 teaching and research assistants, which was accepted. Unit 2 contact instructors received a similar package but with an additional 0.4 percent market sector adjustment in the third year. ${ }^{103}$

Carleton University backed away from attempts to include a new article in the collective agreement that would force graduate students to receive supervisory permission before being eligible to teach a course. Part of 4600 s refusal to entertain this amendment stemmed from the fact that many interpreted this as potentially a disciplinary mechanism in order to speed-up the completion of degrees and, in the process, admitting new revenue sources in the form of new students. Throughout negotiations the Carleton University bargaining team insisted that workplace and student responsibilities were separate and that the terms of bargaining should only extend to basic compensatory negotiations. CUPE 4600 rejected this position on numerous grounds given the manifold ways that the student-worker nexus intersected.

While the union was ultimately unsuccessful in negotiating some basic healthcare benefits for contract instructors, they did sign with the university administrators a memorandum of understanding agreeing to explore what such a plan might look like in time for the next round of bargaining in August 2013. ${ }^{104}$ CUPE 4600 was unsuccessful in winning TA-to-student caps as the university insisted they required a flexible framework (and hence workforce) in order to meet scheduling and course demands. While the university was partially able to implement enhanced

\footnotetext{
${ }^{103}$ The inclusion of a market sector adjustment for contract instructors resulted from the growing wage disparity between Carleton and its cross-town neighbour, the University of Ottawa, which translated into roughly a 14 percent pay differential per course taught to the detriment of Carleton instructors. Although a very minor gain, the significant pay differential remains an ongoing point of contention.

${ }^{104}$ At the end of 2012 they have yet to meet once to explore what such a plan might look like.
} 
surveillance and disciplinary mechanisms in the form of evaluations for contract instructors, the union managed to enact certain restrictions. While the university wanted the ability to unilaterally terminate contracts after two mediocre teaching evaluations, including refusing to renew existing contracts in light of poor previous evaluations, the amendment stipulated that if a member receives a below average evaluation they will be required to complete an action plan implemented in conjunction with the Chair of the department. They cannot be dismissed from that course until the action plan has been implemented and only if they once again receive a below average evaluation.

The administration was unsuccessful in implementing formal teaching evaluations for teaching and research assistants, although a committee was struck to examine the issue further in time for the next round of bargaining. When it came to the university's attempts to increase from 17 to 25 percent the ratio of instructional appointments without a job competition, CUPE 4600 refused on the grounds that this would severely impinge fair access to teaching positions, while potentially increasing the scope of patronage appointees. In the end, the 17 percent threshold remained although language was changed so that the threshold referred to the university level as a whole rather than per faculty.

Collective bargaining also yielded a few other results. CUPE 4600 was able to increase the Employee Assistance Fund from $\$ 95,000$ to $\$ 130,000$ by 2012 ; grievance procedures were clarified; new language was added expanding the definition of healthcare worker for medical leave to include, for example, psychologists and Aboriginal healers; whereas contract instructors were formerly expected to mark deferred exams without pay, a new amendment was added that for each deferred exam contracts instructors would now receive $\$ 150$; and the amount of professional development funds available for contract instructors was increased by $\$ 5,000$ to $\$ 70,000$ per year.

All things considered, the 2010 round of bargaining at Carleton University can be understood as a mixed-bag at best. While the union did advance some minor pay increases, they are 
still below raises in tuition fees and inflation more broadly. Likewise, contract instructors and teaching assistants continue to earn significantly less than their cross-town colleagues at the University of Ottawa. While the university was unsuccessful in drastically increasing surveillance and disciplinary measures, small inroads were nevertheless made which raise the potential for further measures in future rounds of bargaining. Contract instructors continue to not have any healthcare benefits, while anxiety related to potentially poor teaching evaluations and, therewith, the unrenewel of their contracts looms large. On the other hand, despite the climate of austerity CUPE Local 4600's settlements might provide some positive measures that could be built upon in future rounds of bargaining. In successfully reaching a new collective agreement at Carleton University without a strike that included base wage increases, this helped establish a basic floor from which other university sector unions could also bargain. While base wage gains were minor, additional improvements in emergency funding and professional development are of important note.

The experiences of CUPE 4600 also demonstrated that the push back against austerity can result in a much more engaged membership, with new people volunteering and getting active in union positions. Perhaps CUPE 4600's success cannot be measured in its immediate result, but what it will be able to do in the long run. This includes further politicizing the union and building an active rank and file membership, as well as building cross-sectoral support and enhancing their wage and benefit compensation as the austere vice grip squeezes harder. Although there was no major confrontation with the university, CUPE 4600 was able to creatively resist wage concessions as a result of Carleton University's, via the Liberal government's, directive of austerity. With over 2,200 members CUPE Local 4600 made a collective political decision to resist concessionary demands, struggled to reach a fair contract and improved the working conditions of their members. However, despite the noteworthy fight-back, neoliberal policies continue to resurge in the midst of a consolidated program of austerity. 


\section{Neoliberal Redux: Consolidating Austerity}

The origin of the current fiscal crisis is to be found in the Liberals' dogmatic fidelity to neoliberalism and New Public Management policies. In this sense, the relative labour peace between the Liberals and public sector unions between 2003 and 2007 must be put into perspective and revolves around three points. First, lingering resentment over the NDP and a feared return of the Conservatives lead many private and public sector trade unionists, lacking alternatives but also lacking an ideological opposition to neoliberalism, to adapt rather than challenge the political conditions of labour thereby turning to defensive strategies and tactics. ${ }^{105}$ Second, the period 2003 to 2007 coincided with an upswing in the business cycle, emerging in 2003 from the dot-com bubble and $9 / 11$ terrorist attacks, which led to increasing revenues despite a legacy of structural underfunding and continued erosion of revenue streams. This contributed to four years of relative labour peace as increasing revenues allowed for moderate raises in public sector compensation. And third, the Liberals were acutely aware that organized labour lacked both the political will and capacity to mount a significant challenge to their prerogatives. Rather public and private sector unions, to varying degrees, kowtowed to the Liberals in the hopes of benefitting from altruism and goodwill. Despite claims in 2003 that taxes were already "competitive" (i.e. low enough), the Liberal government responded to the Great Recession in the only way neoliberals know how: lower taxes, less services, singling-out the public sector, seeking wage and benefit concessions from unions and further commodifying new spaces for profit-making opportunities. Of course, budgets reveal political choices and the Liberals chose to make the public sector pay for a private sector-led crisis. This is evident in the form of austerity extending to $2017-18$ and demands on public sector workers to take wage cuts in order to supposedly save public services. As part of the Liberals' 2011

${ }^{105}$ As Matt Fodor $(2011, n . p)$ has argued, part of this is because "Political parties less and less represent and organize differences in social classes with radically different political agendas. Indeed, with the never-ending shift to the right of social democracy, all three of the major parties in Ontario have come to accept the major tenets of neoliberalism balanced budgets, a limited state and "competitive' levels of taxation." 
budget, Finance Minister Duncan intimated a hardening climate of austerity when he suggested that upwards of 1,500 positions in the Ontario public sector could be eliminated (Ontario Budget, 2011).

The budget calls for 2 percent growth in expenditures which, given inflation and population growth, continues the aggressive restraint measures first enacted in 2008 and results in real per capita declines. In light of stagnant economic growth the budget defers infrastructure spending to the tune of $\$ 2$ billion (ibid).

Moreover, the budget also established the Commission on the Reform of Ontario's Public Services to be headed by former TD Bank chief economist Don Drummond. In a poignant subsection titled Reforming Public Service Delivery, the 2011 budget argues:

\begin{abstract}
"Just because a government department is delivering a program or service today does not mean it should deliver that program or service in the future. The government will focus on outcomes and results as opposed to how programs and services are delivered.... the [Drummond] Commission will examine long-term, fundamental changes to the way government works. The Commission's work will include exploring which areas of service delivery are core to the Ontario government's mandate, which areas could be delivered more efficiently by another entity and how to get better value for taxpayers' money in the delivery of public services." (Government of Ontario, 2011, n.p)
\end{abstract}

While the first years of the McGuinty Liberals were characterized by a thinly-veiled 'middle of the road' approach to public services and public sector workers, the comments by Finance Minister Dwight Duncan speak volumes about the potential for privatizing public services. ${ }^{106}$ It is important to note that, like the negotiating framework discussed earlier, the Liberals went out of their way in prohibiting the Commission from exploring issues related to new revenue generation such as broadbased value-added taxes, new corporate or income taxes or capital reinvestment quotas. Instead, the establishment of the Commission begins with the assumption of waste and inefficiency in the delivery of public sector services while opening the door to private-sector delivery. While it is still too early to measure the lasting impacts of the Drummond Commission's report on government

\footnotetext{
${ }^{106}$ Released in late-February 2012, the Drummond Commission's (Commission, 2012) report - a densely written 543page tome, outlining more than 600 recommendations - has been harshly criticized for its 'lack of evidence or data to support its recommendations' (OCUFA, 2012, p.1-2). Like OCUFA, others (Noonen, 2012; Foster, 2012) have roundly criticized the report for its flawed methodology, accounting oversights, exaggerated spending increases, overemphasis on government spending and for being constrained by the NPM policies of neoliberalism.
} 
policy and public debate, if past policy practices are an indication of the Liberals' affinity to neoliberalism the Drummond Report is likely to have a resounding future impact on the delivery of public services in Ontario.

Having projected an image of being non-ideological, open to change and tough on wasteful public spending, all the while touting the benefits of public services, the McGuinty Liberals were reelected to a third term in late-2011. Having argued that stability in government was critical in an uncertain economic climate, the Liberals were able to form government although one seat shy of a majority. Despite initially running on a platform in opposition to Harris's market-led revamping of the public service, McGuinty's Liberals have continued along the path of privatization as a boon to capitalist accumulation. In a reversal of their 2003 platform campaigning against the CSR, the Liberals' 2011 election platform has come full circle. The Liberals' have pledged to restrain expenditure growth to 2 percent, vowing not to raise taxes, freeze non-priority program spending and reign in union wages. Perhaps most telling, tax cuts together amount to the second largest platform item estimated to cost the treasury $\$ 327$ million by fiscal year 2015-2016 (Mackenzie, 2011). Since the onset of the recession the Liberals have been clear that Ontario should expect at least one decade of austerity which, when put into historical perspective, continues the assault against public services and free collective bargaining. Ontario holds the unenviable position of being third from the bottom in terms of total public spending as a percentage of GDP among the provinces (Valiani, 2012). These tax cuts will only make things worse for the public sector and most Ontarians. Indeed the writing on the wall suggests that the honeymoon with public sector workers is already over. ${ }^{107}$

\footnotetext{
${ }^{107}$ In the midst of revising this study, the province imposed concessionary contracts on the province's teachers, which followed on earlier legislation restraining spending in the education system. This included a wage freeze, layoffs and the freezing of pensions for five years. Teachers responded with a number of one-day strikes, work to rule campaigns, the withdrawal of extracurricular activities and mass protests. Despite the labour discontent, the job actions did not see a repeat of the Harris-era confrontations. Although it is still too early to draw conclusions regarding the lasting
} 


\section{Conclusion}

As I have argued throughout this chapter, rather than depart from the Common Sense Revolution of the Mike Harris Conservatives, the McGuinty Liberals have incrementally continued along the path of neoliberalization. Although the first mandate of the Liberal government was characterized by relative labour peace, this was not because of a new consensual process of negotiations with organized labour but due to the historically specific economic and political circumstances of the time. Since the onset of the Great Recession the Ontario Liberals have increasingly adopted a more authoritarian form of neoliberalism. In other words, as a result of an economic crisis centred in financial markets public sector workers are being compelled to take a pay cut, give up benefits and shoulder the burden of recession. At the same time, services that workers have contributed to through their tax dollars are being reduced and cut altogether so that those socalled savings can go toward bailing-out private capital in the form of corporate welfare.

As the case study of collective bargaining at Carleton University demonstrates, the university administration sought to shift the burden of the recession onto its most vulnerable and precarious workforce. While there were no major concessions, spaces have been opened so as to create more opportunities for surveillance and disciplinary measures. While CUPE 4600 was successful in generating some minor wage increases, coupled with some improvements in emergency funding and professional development, rising tuition costs and inflation will likely nullify any real benefits. The threat of increasing precarization looms large as the university continues to seek concessions from its workforce in light of declining federal and provincial transfers. Nevertheless, the efforts by contract instructors and teaching assistants in CUPE 4600, which crisscrosses in manifold ways with their position as students, demonstrates that some form of resistance to government-compelled concessions are possible when members are kept informed of 
activities, engaged in outreach initiatives in the broader community and strive to make the connection between public sector workers and public services. While a real opportunity to foster active solidarity between Carleton University's four largest unions was floundered, this may perhaps be one of the lessons learned as collective bargaining moves forward in 2013.

The case study of CUPE 4600 reveals important insights for other unions, particularly in the PSE sector, to draw upon in the continued struggles against concessions. But few if any forms of unionism alone are capable of resisting state austerity and the capitalist class's aggressive push for concessions in the absence of a political anchor and organizational form in which to orient struggles. Furthermore, without an ideological counter to neoliberalism, the actions of the McGuinty government demonstrate that unions cannot rely on elected officials or legal mechanisms to defend past gains but must work to engage the rank and file in a politicized and collective manner. Only then, perhaps, may some unions be able to stem the tide of austerity and, even then, that might still not be enough. 


\section{Ch 6 - Municipal Malaise: Neoliberal Urbanism and the Attack Against Public Services and Workers in Toronto, 2006-2011}

In this chapter, I explore how the Great Recession has led to new rounds of attacks against public sector workers and pressures to privatize public services at the municipal sphere. I argue that through the 2009 round of bargaining between the City of Toronto and its civic workers, the City sought to shift the burden of recession onto workers by positing a false trade-off between wage restraint and the protection of public services. I contend that given the location of Toronto as the strategic centre of financial capital in Canada and home to Canada's largest municipal union, Local 79 , the 2009 round of bargaining served as a measuring stick (or blueprint of sorts) as capital sought to commodify new spaces for accumulation. Rather than retreat from the neoliberal project or present an alternative developmental path in the face of declining revenues, the "Third Way progressivism' of the Miller regime sought to extract concessions from workers using the rationale that the recession demanded austerity.

My analysis is informed by my experiences as a part-time worker with the city of Toronto for more than a decade and as a picket captain through the 2009 round of bargaining. As a Local 79 member, I have worked in a number of positions such as a summer camp councilour, recreational instructor, children and youth program coordinator and leadership development instructor. Given my wide-ranging experiences as an employee and member of Local $79 \mathrm{I}$ am in a unique position to offer an original scholarly overview and critique of what in my view were the most significant shortcomings and limitations of the 2009 round of bargaining. While some of these weaknesses stem from organizational failings, this problematic is related to larger questions pertaining to the significant gulf between the union executive and its rank and file members. In short, the union failed to come to terms with the limits of militancy alone which, in the absence of an oppositional political program, was incapable of countering the drumbeats of austerity and neoliberalism. 
As a result, in the subsequent mayoral election these shortcomings contributed to the election of a conservative mayor and council intent on radically restructuring the city along increased competitive pressures, with efforts to lower the wages and benefits of its public sector workforce and privatize city services and assets. Indeed, in little more than one year since the 2009 civic workers' strike, the Ford Administration had been able to implement a number of regressive reforms which will make work more precarious, reduce access to city services and intensify fiscal pressures to seek further concessions from its workforce. In the absence of a collective capacity to resist such attacks, trade union and community activists in Toronto have much to be concerned about.

\section{Urban Neoliberalism and Public Restructuring in Toronto}

As previous chapters have argued, the mid-1970s can be understood as the beginning of a decade of transition from Keynesian demand-side policies to neoliberal supply-side public administration. In the case of Toronto, while the three decades following WWII emphasized the retooling of war time industries and large infrastructure investments, the period since then can be understood as a continuous process of internationalizing the local economy (Lemon, 1985; Todd, 1998). This entailed reorienting the local state toward expanded accumulation, administrative reorganization and new competitive pressures for private and public sector workers to accept concessions. As a result of both extra-local (international, national, provincial) and local (competition from other municipal jurisdictions) pressures, economic development in the city moved away from manufacturing and goods-producing sectors toward a neoliberal model premised on export services related to finance, insurance and real estate (Lemon, 1985; Caulfield, 1994). Thus current efforts to restructure the city along market lines and competitive pressures must bear this history in mind. 
It is important to recall that since the 1980 s both the federal and provincial spheres of government - when faced with their own budgetary dilemmas - sought to "solve" their revenue shortfalls by eliminating programs, seeking concessions from its workforce and downloading these responsibilities onto other tiers of government without any matching fiscal supports. From Prime Ministers Mulroney and Chretien who drastically reduced transfer payments to the provinces to Ontario Premiers Rae and Harris who froze public sector wages and unilaterally amalgamated cities devolving funding responsibilities, municipal governments have long been subject to 'top down' neoliberalism (Friskin, 1993; Kipfer and Petrunia, 2009). In the run-up to amalgamation, commentators increasingly drew attention to two divergent paths to development best exemplified by the neighbouring cities of North York and Toronto. While the former sought to deal with growth pressures by increasing density requirements, expanding public transit and using the property tax base to fund a range of social services, the latter suburban version was an example of fiscal conservatism, the dominance of the automobile and private services provisioning. Increasingly, the metro Toronto model came to represent the old, decaying order while the North York version represented the future (Keil, 1998). As Desfor et al (2006) have argued, the Conservative provincial government tied its aggressive neoliberal agenda to a reengineering of the local state, but refused to transfer administrative and fiscal powers thereby intensifying inter-city competition between Toronto and surrounding municipalities. ${ }^{108}$ Moreover, because Toronto was envisaged as the strategic terrain through which Ontario was linked to the global economy, Premier Harris' reforms sought to give the local government and businesses the "flexibility" to promote Toronto as a

\footnotetext{
${ }^{108}$ Section 92(8) of the Constitution Act grants the provinces complete authority over municipalities. Thus, without the transfer of any administrative or fiscal supports like the ability to go into debt, print money (in the case of the federal government) and implement a range of tax measures (e.g. income, corporate, sales, resource and import taxes) - tools which remain at their disposal, whether or not they choose to use them -Toronto continues to rely predominantly on property taxes to raise revenue outside of federal and provincial transfers (Todd, 1998). Furthermore, because Ontario municipalities are prohibited from running a deficit, yearly budgets are regularly cost-crunching exercises as city councils seek to balance uncertain revenues with fluctuating demands for city services. As such, the threat of fiscal bankruptcy distinguishes urban governance from national and provincial politics.
} 
competitive "global city" (Kipfer and Keil, 2002). This was done against the backdrop of significant union and community resistance against amalgamation, although by the late-1990s opposition had largely been defeated, fragmented or demobilized (Boudreau, 2000). ${ }^{109}$ The 1998 mayoral election pitted these two versions against each other. When the dust had settled, longtime North York Mayor Mel Lastman's North York neoliberal model emerged as the victor. For Todd (1998), the institutional and administrative redesign of local government, embodied by the electoral victory of Mayor Lastman, represented the victory of a neoliberalized urban political regime more than a quarter-century in the making.

As a "stand in" for Mike Harris (Keil, 1998), Mayor Lastman promised to freeze property taxes for as long as ten years, harmonize downwards civic workers' pay and privatize city services. However, just one year into amalgamation the city found itself short of $\$ 164$ million in tax revenues as a result of downloading making a mockery of Harris's projected cost-savings and Lastman's promise to freeze property taxes for a decade. In what was to become a recurring saga, rather than address the structural deficit at the municipal base the provincial government provided one-time fiscal injections and short-term loans. Keil (1998) has characterized the amalgamation of the city of Toronto as an ill-conceived "solution" by the provincial Conservatives to strengthen their suburban base at the expense of the urban core. Lastman's policies immediately made themselves felt on municipal workers who sought to challenge the authoritarian neoliberalism of the Lastman regime.

In an attempt to remake the local state in the image of its provincial counterpart - more competitive, leaner and efficient -- Mayor Mel Lastman and council attempted to deal with Toronto's fiscal challenges by implementing their own set of 'slash and burn' policies. These

\footnotetext{
109 Amalgamation was forced onto the city of Toronto despite a referendum showing that more than 75 percent of Torontonians were opposed. At the time, community groups and public and private sector unions warned of the serious potential for increasing fiscal problems, as well as deteriorating working conditions and reduced social services in light of increased demands as provincial supports were significantly reduced (Boudreau, 2000; Isin and Wolfson, 1999; Boudreau et al, 2009).
} 
revolved around extracting concessions from workers and freeing-up new spaces for profit-making opportunities. The result was a strike by 18,000 CUPE Local 79 workers over the City's attempts to lower wages, weaken job security provisions, contract-out and privatize services. The strike was the first by Local 79 in the newly amalgamated city of Toronto (WSWS, 2000). Ten days later the union and the City had agreed to send issues related to wage harmonization across the workforce to binding arbitration (where they would remain for more than a decade), while most of the other concessions were taken off the table. In short, the 2000 strike ended in a stalemate.

In 2002, CUPE Local 79 once again struck over renewed efforts to follow through on leftover concessions remaining on the table from the 2000 round of bargaining. However this time the 18,000 member Local 79 was joined by the 5,500-strong CUPE Local 416 . Local 79 is the largest municipal local in Canada, with a membership of 18,000 although various contingent, seasonal and part-time workers push estimates of membership upwards to 24,000 . Local 416 has approximately 6,200 members. Together, they work in areas of public health and education, child and elder care, parks, recreation, water treatment, Emergency Medical Services, as well as housing and court services, road maintenance, by-law and safety enforcement, building inspectors, animal rescue, waste collection and social services administration. Some of its members were deemed “essential" (e.g. EMS workers) and did not strike. Approximately 70 percent of Local 79's members are women with some 50 percent representative of historically racialized groups. At least half are employed in part-time, seasonal and contingent forms of employment, with inconsistent hours and without the supplemental health benefits enjoyed by full-time employees.

Criticizing so-called "job for life", Mayor Mel Lastman sought to outsource waste collection, increase seasonal and temporary employment, weaken employment security, wages, health benefits and pensions, and sell-off city assets. However, little more than two-weeks into the strike, with over one million visitors expected for World Youth Day and the Pope, Conservative 
Premier Ernie Eves (whom had replaced Harris) made use of the coercive act of legislation forcing CUPE back-to-work. The Conservatives continued their heavy-handed intervention in labourcapital relations, which the Mayor of Toronto welcomed based on the "exceptional circumstances" of the religious visit. Absent the enforceable powers of implementing back-to-work legislation and, therewith, the removal of free collective bargaining rights, the conservative administration of Lastman relied on the paternalistic overseer of the provincial government to transfer the work conflict out of the streets and into the courts. In seeking to depoliticize the strike, the provincial Conservatives with the support of Lastman removed (or suspended) the right to strike using the rationale that the economic benefits of World Youth Day and the Pope's visited outweighed workers' rights. In brief, the provincial conciliator assigned to the labour dispute ruled in a way that limited rollbacks of job security and workplace provisions. The issue of wage harmonization across the city's districts, however, remained unresolved as the conciliator requested more time.110

After the 2002 strike by city of Toronto workers was ended with forced legislation, activist union members raised the need to be prepared well in advance of a possible strike in terms of planning, coordination and mobilization and to trying to develop new strategies to garner public support. This included political and workplace education in order to mobilize more and new members, efforts to create tighter bonds with community organizations, as well as initiatives to build rank and file confidence in the membership. As the strike played out and afterward, some members were openly critical of Local 79's leadership at membership meetings, while others were more hesitant for fear of weakening solidarity or out of the hope that they could change the leadership's policy from within. However, despite these tangible concerns by members, it is my contention that in the years following the 2002 strike there were very few sustained efforts to

\footnotetext{
${ }^{110}$ Unfortunately there has been very little subsequent scholarly research on both the history of Local 79 and the 2000 and 2002 strikes. This study is an attempt to begin rectifying and documenting these struggles, although with an emphasis on the 2009 round of bargaining.
} 
regenerate union involvement or to democratize the union and prepare for a future strike. The importance of building an oppositional political project or cohesive political framework was deemed inconsequential as the day-to-day work of the union like grievances related to discipline and promotion were overwhelmingly prioritized. In fact, a rather lethargic state of indifference increasingly seemed to be taking over the membership as the union executive increasingly detached itself from the mass of rank and file members as well as broader community.

The above aside for the moment, it is important to emphasize that the Lastman regime's emphasis on creating a different kind of state was part of a broader strategy of enhancing competitiveness within the city and vis-à-vis other territories. While taxation, financial transfers and intergovernmental jurisdictions have been realigned since 1998, Toronto's labour market has also undergone significant demographic shifts. In the 1960s manufacturing accounted for roughly 30 percent of the city's labour force but by 2007 this had fallen to less than 15 percent. And since 2002, nearly one in five jobs in manufacturing has disappeared (TD Bank, 2007). In Toronto, this process of industrial reorganization is related to capital flight to newly emerging economic regions with cheaper pools of resources, weaker labour and environmental protections, domestic realignment to low-tax jurisdictions and technological displacement amid workplace intensification. In its place has arisen one of Toronto's largest segments of the labour force: employment related to the burgeoning financial, insurance and real estate industries.

\section{'Third Way' Urbanism}

As the centre of financial capital in Canada, Toronto is headquarters to six of Canada's largest insurers, Canada's five largest banks and is the nation's largest employment centre responsible for one-sixth of all Canadian jobs. As a result the city has experienced significant growth of producer services and media capitals, as well as a whole range of low-wage service and hospitality industries, especially professional services tied to housing related demand for credit, 
renovations and legal services. Like other 'global cities,' this has made Toronto highly dependent upon the internationalization of capital - both internationalizing to the world market and entering into Canada (Kipfer and Keil, 2002; Boudreau et al, 2009). For municipalities property taxes remain the major source of funding. And from this they must provide for their public utilities, public works, parks and recreational facilities, waste management, transit services, public housing and a whole range of other social and community services. As such, since amalgamation the city of Toronto has undergone a significant restructuring of both municipal government and services, as well as changes in the city's broader economy. However, it is important to stress that this restructuring was not only a result of extra-local and local economic pressures, but a political process seeking to alter the relationship between the state and market. In other words, it was a politically guided process seeking to alter the balance of class forces in favour of capital at the expense of labour. This restructuring has had especially harmful consequences for the delivery of public services, the workers delivering those services and the users of those services.

As the 2003 election came around Mayor Lastman signaled that he would not be running for reelection. Hopes were high among trade union and community activists that an alternative developmental path may be forged. Four out of five mayoral candidates presented themselves as fiscal conservatives while the fifth, David Miller, differentiated himself from the others based on his opposition to building a bridge from the mainland to Toronto island airport (Kipfer, 2007). As a former NDP candidate, David Miller had forged close alliances with many labour and community activists and sought to present himself as the 'progressive' alternative as distinct from the other candidates and in implicit rejection of the singular business driven model (Kipfer, 2007; Kipfer and Petrunia, 2009). In late-2003, David Miller was elected mayor. However, rather than depart from the legacy of neoliberalism, he ruptured it with selective progressive strands. This alternative had 
largely been defined by notions of building Toronto as a 'green economy,' a 'creative city,' a 'diverse city' and one with 'living wages' (Desfor et al, 2006; Kipfer and Petrunia, 2009).

Mayor David Miller and his political executive came from the 'progressive wing' of Council - a loose alliance between the social democratic NDP, Liberals and a few independents. The electoral basis for this 'Third Way' coalition had drawn extensive backing from public sector unions, the Toronto \& York Region Labour Council (TYRLC) and progressive urban social movements (Keil, 2000; Hackworth, 2008). While in power David Miller governed with the support of these movements in an informal kind of cooperation. The soft progressivism of Miller's alliance, as opposed to the previous right-wing agenda of Mayor Lastman and council members, had initially attempted to forge an alternative developmental project distinct from the singular business driven model of development at all costs. These notions, while having some merits, also demonstrated profound political limitations. Notably, none of them really got at the urban crisis that Toronto faced in light of decades of underfunding. With the onset of the Great Recession, the Miller Administration's embrace of neoliberalism became all the more apparent as a 'progressive' City Council looked to intensify its attack on labour in order to meet its fiscal challenges - challenges generated by capitalism in economic crisis and the policies of neoliberalism, and not overgenerous social services or lethargic city workers.111 Using the recession as a functional rationale, the City sought to extract concessions from municipal workers delivering these key services.

Thus the Great Recession served as a political and economic pretext justifying and intensifying the neoliberal reconfiguration of the city. This was matched by privatization measures, public-private-partnerships, increasing commercial tax breaks, rebranding Toronto and policies for a 'creative city'. Given that one-third of Toronto's expenditures are cost-shared with the province,

\footnotetext{
111 Because of the inadequate funding of the public sector under neoliberalism, it is estimated that Toronto faces a backlog of some $\$ 69$ billion (TD Bank, 2007) in required infrastructure spending. The chronic underfunding of public assets is part and parcel of neoliberalism as governments then look to privatize those services and assets in order to create new profit-making opportunities.
} 
including some financial support from the federal government, what makes Toronto's current fiscal problems unique is that it has merged with unprecedented national and provincial deficits. This has important implications for municipal workers who are expected to bare the burden of decreased economic growth in the form of wage cuts and benefit concessions.

The pressures to increase spending by cities have, therefore, been growing. It is growing from the downloading of service provision to municipalities, but also from increasing population growth, the social dislocations from the economic crisis, and the need for greater urban social and physical infrastructure. Neoliberalism has sought to offload services to cities as a means to reduce redistributional expenditures and state interventions; but it also systematically denies these other pressures on urban expenditures. With a budget equal to or greater than some provinces (e.g. Nova Scotia and New Brunswick), the methods used in seeking to restrain the City of Toronto's (2009) $\$ 8.7$ billion budget has important implications for services provisioning, workers and the users of those services. There are a few points to consider in how these structural fiscal problems have been addressed by the City of Toronto (with similar attempts in cities across Canada) (Hiller, 2010).

First, other levels of government have partly recognized the urban fiscal impasse but have done very little to address it in a fundamental (i.e. structural) way. As a result, since amalgamation but particularly since the onset of the Great Recession, Torontonians have been repeatedly told by councilors and media pundits that they need to get used to less social services, access to community pools, arenas and community centres as well as reduced waste disposal and shelters, library hours and park improvements as part of sweeping "cost containment" measures (Boudreau et al, 2009; Toronto Budget, 2010; 2011).

Second, corresponding city councils have, on the one hand, implemented a range of consumption based (regressive) taxes on all citizens while, on the other hand, shifting away from commercial property-taxes, undervaluing business land assessments and providing grants and 
financial assistance for large corporations (Toronto Budget, 2010; 2011). Under the provisions of the new City of Toronto Act (2006), Mayor David Miller took the opportunity to institute an array of so-called "flat taxes" in the form of the Municipal Land Transfer Tax (MLTT -0.5 to 2 percent levy) and the Personal Vehicle Ownership Tax (PVOT - a $\$ 60$ municipal vehicle registration fee). Both measures were implemented in conjunction with already-existing provincial fees. At the same time, however, City Councilors also "approved generous property tax breaks to attract high-paying, knowledge-economy jobs to strategic areas of the city, although the business community is already urging the city to further sweeten the pot." (Hanes, 2008).

These incentives include Brownfield remediation (city subsidies, tax incentives and/or deferrals for major capital investments in properties requiring environmental clean-ups or in underdeveloped areas of the city), as well as Tax Incremental Equivalent Grants (TIEGs) which include reduced property taxes and electricity rebates for large commercial developers (Toronto Budget, 2010; 2011). Demonstrative of the neoliberal market mantra that predominates at City Hall, councilor Karen Stinz professed: "The plan will pay dividends in the long-term. Once the pie grows we'll all get a piece of it." (ibid). Contrary to Stinz's 'trickle down' allusions, however, the economic crisis has only deepened Toronto's fiscal hole while these tax breaks favour the business class at the expense of the public sector workers and those who rely on public services. As the 'progressive coalition' at City Hall insisted on concessions and reductions to services, one of the few exceptions in speaking out against service level and staff cuts had been radical sections of the anti-poverty movement (Clarke, 2008; Bradford, 2009). And for good reason: the poor have seen a continued deterioration of urban services from Lastman over to the Miller period, with nearly 300,000 more Ontarians, a large portion of which reside in Toronto, in poverty in 2009 compared with 2007 (Montebraaden, 2011). 
Third, there are pressures to renew the contracting-out of city services and employment, and privatization of some capital assets as a means of temporarily relieving its immediate budgetary ailments. City council and administrators continue to raise, and the Toronto Board of Trade and other business associations lobby for, privatizing Enwave, Toronto Hydro and the Toronto Parking Authority. Assets with a combined value of $\$ 60$ billion. This includes a massive project of (re)commodification most clearly evident in the city's attempts to contract-out waste collection, childcare, recreation and other services, as well as privatizing Regent Park, Toronto's most wellknown public housing project (Kipfer and Petrunia, 2009). But the actual evidence of outsourcing and privatization in North America, particularly at the municipal sphere, suggests that the privatization of formerly public-sector jobs - and the experiences of private sector building projects on urban transport and infrastructure projects in Toronto - has correlated with more expensive and less efficient goods and services, reduced public oversight and a lower quality of services provisioning (Armstrong et al, 2001; Loxley, 2010; FCM, 2006; OHC, 2008). While the sale of assets and contracting-out may provide one-time fiscal injections, they are unlikely to solve the underlying structural crisis facing Toronto.

Fourth, the City continues to seek wage freezes and concessions from its city workers with the idea that in reducing its direct wage bill the fiscal problems of Toronto could be eased. However, as Greg Albo and Herman Rosenfeld (2009, n.p.) have argued: "Toronto's fiscal challenges do not reside with the wages of city workers. They emerge from the distributional and tax policies that the city has adopted, and the wider economic crisis of capitalism. In particular, the failure of governments to properly fund welfare while using ever more of municipal budgets to fund policing and security operations, and the incessant campaigns at 'branding' the city to subsidize business needs closer scrutiny." Moreover, as CAW economist Jim Stanford who sat as part of the city of Toronto's 2007 Independent Fiscal Review Panel has argued, despite being generally well- 
run at the operational level and comparatively efficient, Toronto's fiscal challenges are a result of an ongoing structural deficit: "In reviewing financial data on the city's compensation costs, our report debunked the stereotype that the city's employees are 'fat cats'...average compensation for unionized workers (including overtime) was less than $\$ 40,000$ in 2007." (Stanford, 2008). All things considered, despite a series of connections linking the city's fiscal crisis to historical and contemporary circumstances, none of which are attributed to overgenerous social services or excessive public sector compensation, the Miller Administration sought to extract concessions from its workforce using the wedge strategy that public services depended on wage restraint. In employing the rationale that the severity of the recession required broad-based municipal spending reductions, the Miller Administration - despite its alleged progressivism - came to actively impose the dictates of neoliberalism.

\section{Collective Bargaining at City Hall}

The persistence of neoliberalism in Toronto, despite a 'progressive coalition' governing at city hall and new cooperation with labour and urban social movements, raises important questions about extra-local political pressures and economic constraints that cannot be resolved at the level of city government. It also raises issues of how local 'progressive' coalitions come to reinforce these neoliberal constraints, rather than build an empowering politics and new political capacities that challenge them. In particular, the problem is how these 'progressive' political coalitions have come to demand, and actively seek to impose, discipline from workers and unions to cope with these fiscal, political, and local constraints while the demands of the capitalist and professional classes are accommodated and incorporated in urban policies. How, then, did council rationalize going after workers wages? In what ways did the unions respond to such attacks? And what are some lessons that might be learned in the continued struggle against concessions? 
Since Local 79 was the largest union on strike and I served as a trade union organizer and picket captain, I will restrict most my comments to the central issues which Local 79 encountered. Seven issues were central to this round of bargaining. (1) Both leaderships of Locals 79 and 416 entered into bargaining with the understanding that the City would be attacking the controversial Sick Leave Benefit Program (SLBP), which allowed for the banking of sick days; (2) trying to weaken job security provisions and seniority rights; (3) limit transfers and promotion; (4) impose a freeze on cost-of-living increases to wages; (5) implement two-tier wages; (6) contract-out employment; (7) and increase managerial control over the labour process through enhanced disciplinary and surveillance measures. In the lead up to the strike, Mayor Miller argued that "The world has changed" and the City needed to cut back on its labour costs and come to terms with the grim economic realities of the "new economy" (Jones, 2009). ${ }^{112}$

Members made clear to union officials at membership meetings that it was essential to continue the wage pattern that had led to settlements with other city unions (such as police and firefighters, Toronto Community Housing Corporation, Toronto Port Authority, Toronto Parking Authority and Enwave), resist employer efforts to eliminate sick day provisions and their banking toward a severance payment upon retirement, oppose concessionary demands and reject attempts to privatize public services. Given the climate of austerity that prevailed at city hall, the union did not go into bargaining with any central demands, most were related to procedural mechanisms, addressing language related to transfer and promotion and the optimistic hope that the city might entertain some healthcare benefits for its part-time staff. From January to June 2009, the bargaining team and representatives of city council met regularly to discuss a new collective agreement. At membership meetings, representatives of the bargaining committee and officials made clear that while a new agreement has not yet been reached they continue to work together with the city to

\footnotetext{
112 The rhetoric of the "new economy" has been a buzzword for neoliberal advocates since at least the 1980s, however its usage often obscures more than it reveals. See Pupo and Thomas, 2009.
} 
reach a fair deal. This was reflected in the bargaining teams often repeated mantra that they continue to make progress.

But despite bargaining for six months without a contract, Local 79's executive gave little indication - publically or at membership meetings - of just how far apart the two sides actually were. With only hours remaining before the strike deadline, the Local 79 executive haphazardly put together a strike coordinating team demonstrating its unpreparedness for the dispute. The Local leadership not only failed to mobilize its members but, aside from a few ill-advised radio ads, did not engage other workers in Toronto with any political or educational campaigns or messaging. CUPE National was reduced to providing administrative support. After six months of negotiations without a contract and little movement during collective bargaining, city of Toronto workers in CUPE Locals 79 and 416 went on strike on June 22, 2009. ${ }^{113}$

Part of the reason for CUPE National's limited role had to do with the fact that Local 79 was the largest CUPE Local and the leadership did not take kindly to centralized directives from the national offices, although staff members did provide valuable administrative and operational support. In striking contrast to the experiences of PSAC Local 70396 and CUPE 4600 discussed in chapters four and five, in the lead up to the strike Local 79's leadership failed to publically make the connection between communities, public-sector jobs and services or why it was important to support workers defending decent employment conditions and wages.

In fact, as membership meetings during negotiations suggested, Local 79 President Ann Dembinski intimated that 'progressive' Mayor Miller and Council would come through for the public-sector unions that had backed his election campaign so forcefully and that a fair contract without any concessions would be reached. Much to the dismay of the union officialdom, however, management did not budge and both Locals soon found themselves walking the picket line.

\footnotetext{
${ }^{113}$ Parts of this section draws on arguments previously published in Barnett and Fanelli, 2009; and Fanelli, 2009; 2010.
} 
Demonstrative of the union's unpreparedness, when Locals 79 and 416 officially went on strike many workers showed up to work surprised to learn that they had been locked-out by the employer. Many of the 24,000 striking workers simply did not know where to go or what to do. Picketing sites were unknown, where and how to register for picket duties were unspecified, picket captains had not been trained and there were few informational materials for members. The website was not updated until days into the strike and remained limited to very general information. With the start of the strike the 'progressive' political coalition that governed city hall found itself increasingly under strain.

The doublespeak of Mayor Miller, accompanied by the silence of 'leftist' councilors at City Hall is worth brief mention. The Mayor attempted to pit striking City workers against others in the most poverty-stricken and destitute living situations by arguing that due to the economic downturn and rising welfare caseloads the City could not sustain union wages and social services (a similar rationale, as argued in previous chapters, deployed by the Ontario Liberals and to a certain extent the federal Conservatives). The structural and administrative reasons why the City was having financial problems received scant attention from the Mayor, Councilours or the media. Instead, the Mayor, Council, sections of the business community and right-wing media used the excuse of allegedly inflated union wages and benefits to justify their attacks on City workers and services. The unions' bargaining platform was straightforward and revolved around two basic points: equality with settlements recently reached by other unionized workers with the City and no concessions. As argued, it was clear from the beginning that Local 79 was unprepared strategically and tactically but also politically in important ways. First, there was a lack of experienced organizers leading the strike. The Local president had never been an organizer of a Local 79 strike nor had most of the current members of the executive committee. Second, the union did not book union organizers off as full-time organizers until right before the strike was set to start, resulting in 
a disorganized and unprepared executive which trickled-down to the rest of the membership. And third, financial and personnel resources were allocated in ineffective and inequitable ways across the city's regional strike offices. For example, members with disabilities or health concerns were not adequately provided with modified strike duties. Despite the fact that Toronto is one of the most expensive cities to live in, no hardship fund was set up as the strike went on and strike pay coordination was initiated only after the strike had already begun. Perhaps most problematically, however, the Local 79 bargaining committee acted in almost complete isolation from the rest of the membership treating them as less knowledgeable mere background players.

As a result, by the end of the first week on strike many members experienced a lack of solidarity, mounting public resentment and increased feelings of marginalization. This was reflected in low morale on the picket lines and an unawareness of the key issues involved in negotiations. There were, of course, exceptions. Many experienced activists with a commitment to the membership and a strong sense of social justice sought to consistently provide information to picketers, boost morale and historicize strike actions. On some picket lines a real sense of union solidarity was created and nurtured as workers united and the (class) antagonism between workers and the employer became clearer. Many also began raising difficult questions about the practices of the city, union and larger systemic issues related to Toronto's fiscal concerns. But these examples were the exceptions and not the rule. During the strike, members of many other union locals and community activists showed their solidarity with striking city workers in the form of strike support barbeques, media releases and public rallies. Unfortunately, though, the lack of concerted mobilizational efforts, little to no media attention for pro-strike voices and an inability to link strikers' struggles with the broader attack on public services and on other unions, limited workers' traction with the general public - many themselves facing grim circumstances in the midst of the recession. It also became clear that Toronto's broadly defined coalition of progressive forces both 
inside and outside of Toronto's unions were unable to mobilize in an effective way around the strike.

In contrast, right-wing critics had a field day blaming so-called selfish unionized workers. They pointed to garbage piling up on the streets and criticized Mayor Miller's hesitation to go for the throats of striking city workers. It was clear that conservative media forces had overwhelmingly won the public relations battle as evidenced in editorials and public opinion polls (Colvin, 2010). Conservative organs such as the National Post, Globe \& Mail, CTV and Global TV lined up against the strike. Perhaps none, however, were as vocal and consistent in their vitriol as Toronto Sun writer Sue Ann Levy. In a barrage of articles during the strike, Levy regularly berated the "pinkos" at "Socialist Silly Hall" doing much to flame the public backlash against "out of touch" and "greedy" union members (see, for example, Levy, 2008).

As if out of nowhere - after 36 days on strike - word had trickled down to Local 79 members that Local 416 had reached an agreement. Within a few hours, Local 79 had come to a similar tentative agreement. What was most striking, however, was not that members first received the news from media sources, but that the information gap had grown so large between the union executive and rank and file members that the most immediate question on members' minds was "did we win?" It is important to recall that many strikers were unaware of why exactly they were on strike in the first place and were dependent on media reports to find out where both sides stood during collective bargaining. Much of the information that picketing workers did receive was inconsistent, late or lacking substance leaving strikers feeling frustrated and left out of the process. Of course, post-strike assessments are never as simple as "did we win or lose?" But there are 
important political and organizational lessons to be learned from the tumultuous summer when thousands of municipal workers walked the picket lines in Toronto. ${ }^{114}$

Economically, both Local 79 and 416 managed to fight off major concessionary demands to freeze wages, institute a multi-tiered wage system, limit seniority-based promotion and replace the banking of sick days and cash-payouts under the SLBP with a short-term disability (STD) plan (now called the Illness and Injury Plan - IIP). Under the deal to end the strike, current workers were able to cash-out their accumulated sick-bank and switch to the IIP plan or keep their existing SLBP. The SLBP is no longer available to new hires however. Locals 79 and 416 were successful in gaining 2 percent raises over 3 years (which was still below what other city of Toronto unions received and Council's own 2.4 percent pay increase, including the retention of their own "merit" bonuses and severance packages). Local 79 part-timers, however, did not see any extension of benefits nor do they have a sick plan. The other concessions were taken off the table.

During the strike the much-maligned SLBP got the bulk of attention from the media, along with the piles of trash, as management and media pundits isolated populist issues as a wedge strategy to garner public support. On numerous occasions when members asked Local 79 President Ann Dembinski what was wrong with a STD plan - such as the one that members of Local 79 who were formerly employed by the City of York still had - she dismissed and ignored the question, narrow-mindedly defending the banking of sick days. The short-sighted union posture that retreating from the SLBP would represent a concession, almost mechanically associated with failure, proved unnecessarily restrictive and unimaginative. Would not fighting for the best possible STD plan have been a better idea than simply defending the existing SLBP? Could the loss of the SLBP been translated into a positive gain or used elsewhere as leverage? At membership meetings

\footnotetext{
${ }^{114}$ Like Toronto, civic workers in Windsor, battered by the automotive crisis and facing one of the highest urban unemployment rates in Canada, also went on strike in the summer of 2009. The strike included about 1,800 workers who work in waste, road maintenance, daycare, by-law enforcement and recreation. The city sought to implement twotier wages for new hires and remove post-retirement benefits for new employees (see Noonen, 2009).
} 
some Local 79 members reminded the executive committee that the SLBP had long been used by management as a way of limiting wage and benefit increases, thus perhaps it could be used as a bargaining tool elsewhere such as the extension of some gains to part-timers or more paid time-off. Furthermore, it also indirectly encouraged workers to show up to work unwell so that they could cash-out unused sick days at a later point in time. A policy which, perhaps unfairly but understandably, garnered much negative public reaction. Unfortunately, such concerns generally fell on deaf ears and criticism was interpreted as disunifying.

In my view, however, the economic gains of the strike are little more than a hollow achievement. In fact, the political implications of the strike may far outlive the minor and potentially temporary economic benefits of the agreement. The strike was a political failure when it came to mobilizing sustained action and education, garnering public support as well as linking the defense of unionized workplaces with fighting for workers in non-unionized jobs, the underemployed and unemployed. Furthermore, the agreement did not make work any less precarious, particularly for part-timers. With some political imagination the strike could have been strategically situated in relation to a number of related issues. For example, issues related to public services and privatization, taxation and revenue generation as well as precarious work and poverty. Likewise, decades of downloading might have been related to the causes of the Great Recession and, by extension, larger political concerns such as who benefits and who is made to pay in times of "crisis." While the strike was not an absolute failure, illusions about the strike being a victory only serve to politically disarm workers in the face of the ruling class's ongoing offensive, paving the way for further defeats. 


\section{From Miller Time to Ford Nation: Austerity Intensified}

Following on the heels of the strike, Budget Chief Shelly Carroll, with the backing of Council, implemented a 5 percent reduction to all departmental expenditures across the City (City of Toronto, 2009). What's more, council moved forward with both new tax and fee hikes and further cuts in services: water rates rose 9 percent, property taxes by 4 percent (having increased 12 percent since 2005), and the renting of city-run facilities and recreational programs by 4 percent, in addition to a host of new user-fees for swimming and skating. Likewise, both recreational programming hours and the number of youth outreach workers were reduced (ibid). The 2009 strike by Toronto civic workers ended in the midst of the Great Recession, with little more than one year to go before the next municipal election. In this sense, the 2009 strike served as a political lightningrod in the run-up to the next election as the recession continued to evolve.

By early-2010 David Miller had let it be known that he would not seek reelection. Eight candidates had initially put themselves forward, although three were seen as major contenders (Ridler, 2010). George Smitherman, a former cabinet minister in the Dalton McGuinty government got off to an early lead; while long-time councilour and Deputy Mayor under David Miller, Joe Pantalone, struggled to disassociate himself from the Miller regime and lingering public resentment over the civic workers strike. But as the mayoral contest continued, staunch conservative candidate and councilour Rob Ford steadily gained momentum using the 2009 strike as a policy plank to direct public anger and frustration toward so-called lavish union wages and wasteful city spending (Kohler, 2010). On October 25 2010, the most fiscally conservative Councilor in the previous term, Rob Ford, was elected the new Mayor of Toronto. Indicative of a shift in the centre of political gravity at city hall, the 'progressive' wing at city Council had been replaced by a new right-wing populist mayor and a majority conservative Council. Mayor Ford was joined by a new bloc of rightwing Councilors, who all but swept suburban wards across the city (Saberi and Kipfer, 2010). 
Toronto's so-called 'centre-left' forces failed to hold support, while various labour and community groups failed to organize in an effective manner against the drumbeats of right-wing populism (Lorinc, 2010; Albo, 2010). Much like former Ontario Premier Mike Harris' political platform of the mid-1990s that drove the provincial turn to neoliberalism after the failures of the prior 'progressive' government, Rob Ford (whose father was a Member of Harris' Conservative government) took advantage of a similar political environment at the city level.

Like Harris before him, Ford stuck to easily absorbable talking points - tax cuts, less government, public sector reform and enhanced business investment - and rode to power deriding the alleged waste and inefficiency that prevailed at City Hall (Kohler, 2010). In the vitriolic rhetoric that characterized the campaign, Ford vowed to put an end to the "Gravy Train." As the Globe \& Mail put it:

"During his mayoral bid, Mr. Ford tapped into the wellspring of resentment over that strike [2009 civic workers' strike] to propel himself to victory, and he and other supporters of privatization raised the spectre of it several times... While the day brought some compromise, the Mayor worked from the onset to draw a sharp ideological line among Council members, characterizing his critics as 'tax-and-spend socialists.' We are going to divide ourselves up into two groups,' he said. 'This is going to be very simple for the taxpayers to see."' (Church and White, 2011).

The 2009 civic workers' strike remained fresh in the minds of the electorate as Ford continuously contended that Toronto had become a fiefdom for powerful, monopolistic and uncompetitive unions - themes that the stance of the former Miller-led council fed into. Throughout his campaign Ford pledged that he would stand up to Toronto's unions, privatize assets, contract-out services and reduce the financial burden for Torontonians by showing "Respect for the Taxpayer" - Ford's election platform slogan (Kohler, 2010b). These themes, not the bailout of the banks, G.M. and Chrysler, tax cuts for the wealthy, and the reckless downloading of services, dominated election coverage. 
Dubbing his supporters "Ford Nation", Ford pledged to aggressively undertake neoliberal reforms. ${ }^{115}$ While Ford and Council advocates have yet to fully implement his campaign platform promises, within a year there had already been some important Ford victories. This includes: eliminating the $\$ 60$ vehicle tax; freezing property taxes for 2011; cutting Councilours' expense budgets from $\$ 53,000$ to $\$ 30,000$; reducing funding for libraries; eliminating TTC bus routes; scrapping Transit City; having the TTC declared an essential service by the province; selling off 22 community housing units; listing the Toronto Zoo and three city-owned theatres for sale; and privatizing a portion of Toronto's garbage collection (Dale, 2011; Vincent, 2011; TEA, 2011). Ford and his allies on Council have also sought to slice all departmental budgets by an additional 10 percent (or $\$ 360$ million in total cuts), while increasing user-fees for rentals, recreation and arts programs by, on average, 3 percent (Toronto Budget, 2011). Still on the agenda are proposals to sell a 10 percent stake in Toronto Hydro (which has earned the city $\$ 2$ billion since amalgamation), selloff the city's 43 percent stake in green energy company Enwave, sell 706 subsidized housing units, eliminate the city's Christmas Bureau (a subsidized charity that helps distribute gifts to needy children) and end police paid-duty at construction sites. City council also voted to study privatizing daycares and nursing homes, and is considering further reducing library hours and eliminating a Hardship Fund that helps the poor pay for essential medical items such as wheelchairs and casts. Hundreds of parcels of land are also for sale (Dale, 2011b; Toronto Star, 2011; James, 2011).

115 This included: Eliminating the $\$ 60$ vehicle registration tax (worth roughly $\$ 50$ million in annual revenue); Eliminating the land transfer tax; Freezing property taxes for 2011, and then tying them to inflation in the future; Reducing workers through attrition; Halving the size of Council from 44 to 22; Halving Councilors' $\$ 53,000$ expense budget; and opening-up Toronto's childcare services (the country's second largest with 24,000 subsidized spots) to P3 delivery models (IBIKETO, 2009; Kohler, 2010). Additional measures extended to: seeking to privatize everything from Enwave, Toronto Parking Authority and Toronto Hydro to the building of parks and recreation facilitates and Wheel-Trans; Selling-off Toronto Community Housing Corporation (worth $\$ 6$ billion in housing stock), affecting roughly 164,000 tenants; Eliminating, if not decreasing, City subsidies for arts and culture, including cuts to library and recreational budgets; Asking the province to turn the Toronto Transit Commission (TTC) into an "essential" service, therefore preventing workers from directly withholding their labour; Scrapping the City's Fair Wage policy; And privatizing the Toronto's waste disposal services (ibid). 
Given Ford's drive to radically revamp the contours and delivery of public services, it is no surprise that he and Council are also seeking to squeeze more "productivity" out of workers, stripaway benefits and lowering the quality of service provision. For instance, since taking office Toronto's public sector has been reduced by 2,000 workers (a $\$ 140$ million cut), mostly from leaving vacancies unfilled, with explicit plans to reduce them by another 7,000 (Maloney, 2011b). Ford has been unapologetic in arguing that "The gravy is in the number of employees we have at City Hall." (Dale, 2011c). It is clear that the crisis and the drive to austerity are hardening neoliberalism, particularly at the municipal level. Ford continues on with his mission to privatize as much as possible using the rationale that the budgetary crisis - formed in good part by the freezing of taxes and the decline in fiscal transfers - is caused by a 'spending problem'. As a result, Toronto has become accustomed to the yearly spectacle at City Hall of crunching numbers, unexpected surpluses and shifting about of funds (and emergency injections from the provincial government, from an implicit rejection that the download of services has been an administrative failure). For example, in 2006 the expected shortfall was $\$ 646$ million and in $2010 \$ 821$ million. Each 'crisis' was resolved without any serious cuts, as various city funds were deployed and the province kicked in emergency funding (James, 2011c). In financing his first year in support of a 'balanced' operating budget for 2011 , Ford used $\$ 330$ million of the surplus left over by former Mayor Miller, froze property taxes (despite being one of the lowest in the Greater Toronto Area) and TTC fares, in addition to introducing \$23 million in new user fees for 2011 (Maloney, 2011; Toronto Budget, 2011).

Despite the changes, what is certain is that Ford's promise of neither increasing taxes nor cutting services was an utter electoral fantasy. This is most clearly evident in Mayor Rob Ford's campaign pledge to remove Toronto's land transfer tax. Expected to bring in nearly $\$ 300$ million in revenue in 2011, it is hard to imagine how such an important revenue stream could be replaced 
(Maloney, 2011b). ${ }^{116}$ Unfortunately, given the Ford Administration's dogmatic fidelity to neoliberalism, it is likely that urban needs will continue to go unmet and the quality of services will decline, as the contradictions embedded in capitalist urbanization in Toronto deepen. In failing to address the roots of Toronto's fiscal woes, Ford's budgetary hopes are based on radical budgetary cuts and one-time fiscal injections that seek to turn public assets and services into profitable outlets for private sector capitalists. The purpose of these neoliberal budgetary policies is to transform the nature of government, bolster capitalist profits and disorganize workers.

Rob Ford's first major stab at privatizing Toronto's public services easily passed when Toronto City Council voted to contract out a portion of garbage collection in District 2 (Yonge St. to Etobicoke border), potentially laying off upwards of 300 Local 416 'temporary workers' (Ridler and Maloney, 2011c). In addition to outsourcing garbage collection, the plan also seeks to increase the number of Litter Vac Operations conducted by private contractors from 12 to 29 , contract-out Litter Bin collection within City parks and supplement curbside residential waste collection by private contractors on a call-out basis. This is in spite of the fact that two separate studies examining the viability of contracting out waste collection found the City Staff's report recommending garbage privatization to be significantly deficient. ${ }^{117}$

\footnotetext{
${ }^{116}$ In fact, an additional benefit to Toronto's land transfer tax is that in keeping pressure off of property taxes most Torontonians are not affected unless they are engaging in the buying and selling of property. This has the added benefit of throwing some sand in the speculative wheels of Toronto's property markets; what some have argued are among the most inflated urban condo development and residential property markets in Canada (Macdonald, 2010; Baluja, 2011; Dobby, 2011; Blakely, 2011).

${ }^{117}$ For instance, the Toronto Environmental Alliance (TEA, 2011) found: "Significant evidence exists that waste diversion has been jeopardized by private waste collectors...City staff have seriously over-estimated the potential savings from privatizing waste collection west of Yonge St. because they have under-estimated monitoring costs." The private contract, worth roughly $\$ 250$ million over seven years, not only inflates savings by at least $\$ 4$ million per year, but failed to incorporate in their analysis the danger of 'put or pay' provisions. This had significant implications, for example, in the city of Ottawa, which signed a 20 year contract with OrgaWorld to collect 80,000 tonnes of waste per year at $\$ 100$ per tonne. In 2010 OrgaWorld only collected 53,000 tonnes, which meant that the city of Ottawa paid nearly $\$ 2.5$ million for waste that was uncollected (TEA, 2011). Should such a clause be implemented in Toronto's case, this could have especially costly consequences given Toronto's goal of 70 percent waste diversion from landfills. Forensic accountants Rosen \& Associates also found the Staff report inadequate. They suggested that the $\$ 6-8$ million estimated annual savings rely on two factors: cheaper labour costs and cheaper per tonnage waste collection. They warned: "In our opinion, the financial analysis that has apparently been relied upon to date, and the decision-making process for the proposed contracting out of waste collection, is seriously flawed and grossly inadequate...Simply stated,
} 
If killing Transit City and contracting-out a portion of Toronto's waste collection has been the most visible of Ford's restructuring of city services, it was not his most comprehensive. In Spring 2011, Ford and a $\$ 3$ million team of "gravy sniffing" consultants undertook a six month Core Services Review (similar in kind to the provincial Drummond Commission) that could dramatically increase the scope of private sector provisioning of services (Ridler, 2011). In addition to in-person and online consultations, the review panel sought to determine where the knife should shave and where it should cut in severing city services and assets. The City will also undertake a "service efficiency study" to find where improvements in economic performance can be made, as well as a user-fee review exploring whether the city could raise the more than 1,000 different fees it collects to the tune of \$1.4-billion. Across his entire political career, Ford has argued for turning public goods and services into profitable investments for the private sector, under the veil of greater innovation and efficiency (White, 2011).

The recently initiated Core Services Review aims to provide the political and ideological rationale for such an undertaking. KPMG's report puts forward a catalogue of suggestions for cuts to the City of Toronto's budget. ${ }^{118}$ The KPMG report represents a significant intervention into

the Staff's cost efficiencies of contracting out would have to be labeled "fictional." Available facts do not support Staff's claims. Claims of cost savings could easily become additional costs for contracting out." (Rosen \& Associates, 2011).

${ }^{118}$ In terms of service delivery the report suggests lowering targets to "standard service levels" (i.e. provincially mandated), with some kept above or below standard levels; Eliminating or reducing support for small- and mediumsized businesses, particularly in "Business Improvement Areas"; proactive investigations and enforcement of business licensing; support for entrepreneurial grants and other services, including those related to film, arts and culture; Eliminating or reducing emergency funds to help the elderly and disabled purchase emergency medical supplies; subsidized recreational activities for low-income earners and children; a program that distributes Christmas gifts to needy children; and a hardship fund that subsidizes funeral costs for poor residents; Eliminating or reducing the City's "very aggressive" recycling target rate of $70 \%$ diversion from land fill sites; Toxic Taxi hazardous waste disposal service; Community Environment Days; and public library branches and hours of operation; Contracting-out or reducing windrow (large piles of snow) removal, street sweepers, snow clearing, de-icing, grass cutting and park maintenance; four free garbage tags program; water fluoridation; and payroll runs. The report also proposes outsourcing or privatizing residential solid waste, including the elimination of small commercial waste collection; waste diversion enforcement; old-age homes; childcare, particularly 2000 formerly subsidized spaces; inspection of childcare services; integrating EMS and Fire Services; inter-hospital transfers by ambulance; 311 activities; administrative services; recreational programming and activities; and public arts and culture programming; Eliminating horticultural activities, particularly those "aesthetic in nature."; Urban Agriculture Services, small zoos and farm attractions; Toronto Environment Office and Toronto Atmospheric Fund which does research, dispenses grants and offers programs to encourage ecologically sustainable cities; cat and dog licensing; and some health care programs (e.g. AIDS prevention, 
public policy debates and is particularly important for this study because it unmistakably proposes a full-out neoliberal assault against the public sector delivery of services. However, it is important to stress that the reports rely almost entirely on presumed savings - that is, assumptions based on theoretical projections and no real evidence. The KPMG reports do not uncover any real 'savings' in the sense of efficiencies in delivering the same level of services. All the so-called 'savings' come at the cost of declining service levels, redistribution, access or quality and presumed lower wages for private sector delivery. In an effort to further meet its cost savings target, the City also recently announced it would be offering some 50,000 workers a buyout package (White, 2011b). ${ }^{119}$

Similar in kind to the KPMG-Mowat Centre report discussed in chapter five, this has been a recurrent consequence of the neoliberal public administration that KPMG advocates in which they gain by first advocating the cuts and then coming in to help administer the services just cut and privatized! A range of commentators have made similar observations, with even cracks appearing in the right-wing media that has backed Ford and the austerity agenda. As one article put it, Rob Ford's fiscal agenda has been exposed as a "canard, a massive con job" (Ridler and Maloney, 2011). Another finds KPMG's report offering "lots of bone and almost no fat" (James, 2011b). Even the National Post, a refuge for all things conservative, was forced to admit that Ford's campaign mantra is running out of gas, even conceding that Ford's declaration of "50 million to $\$ 100$ million" in savings as a result of KPMG's report was "mythical" from the beginning (Selley, 2011).

dental health and student nutrition); Adding new user-fees for providing information to the public and filing applications (e.g. increased permit and application fees, recreational programs and rental usage); Cutting parts of the TTC's late night and weekend bus routes; Privatizing a portion of the TTC's traditional routes, as well as the Wheel Trans service; And finally, selling-off Exhibition Place; Toronto Zoo; off-street parking lots; and City-owned theatres (Toronto, 2011b).

${ }^{119}$ Writing in the Globe \& Mail, columnist Andrew Steele (2011) presented one potential scenario from such a blanket, unthinking administrative measure: "Imagine if the vast majority of the dynamic IT staff at the city decided to take packages and move to offers in the financial services industry. In a couple months, the city would see increased problems with websites, system reliability and telephony. More expensive consultants could fill the gap until permanent staff were lured to join with incentivized pay packages and bonusing. Not only are the original cuts growing back, but they are higher-cost people in the same job. Quickly, the cure becomes more expensive than the disease. Haphazard cutting never lasts." 
As Christopher Hume (2011) has argued: "Throw in enough charts, footnotes, acronyms and, best of all, 'a core continuum,' and the whole thing starts to feel more like a formal economic exercise than an ideological intervention, pure and simple." Indeed, the KPMG report completely underplays its own results that found that 60 percent of the 13,000 respondents to a city core review online survey said they would be willing to pay a 5 percent increase in property tax to maintain current service levels (Toronto, 2011b). Two later survey's found such support actually increasing with a strong majority of Torontonians against reducing TTC service routes, child care spaces, selling long-term care housing and a range of other services (Ridler and Dale, 2011; Ridler, 2011c; Thanh Ha, 2011).

Much headway has been made in the commercialization and privatization of City services apart from the Core Services Review however. Toronto Council, for instance, passed a new initiative that would sell advertising space on the city's transit system, including naming rights for subway lines and stations for $\$ 324$ million over 12-years. They have also moved to eliminate some police station cleaners with CUPE local 79 and 416 (Ridler, 2011c). ${ }^{120}$ Just as at other levels of government delivering austerity explored in this thesis, urban neoliberalism under Ford does not necessarily mean less state, but a particular kind of state (Albo et al, 1993; Todd, 1998). One geared toward reducing public services and assets in order to open-up new avenues for profit-making opportunities and enhancing competitiveness all the while lowering wages, benefits, working conditions and creating a precarious workforce that is ever-more market dependent.

The problems of Toronto's current budgetary impasse are not unique to the Ford administration. But Ford's own contribution to its making is not without important political

\footnotetext{
${ }^{120}$ At the same time the Ford administration awarded the Toronto Police Association a significant 11.5 percent wage increase over four years adding as much as $\$ 80$ million to the city's bottom line (Doolittle, 2011). Taking into consideration the ballooning costs of Toronto's police services, and despite already being the highest paid officers in the country, such an act clearly parrots the law and order agenda of his federal Conservative counterparts, which has been so integral to Ford's populism, even at the expense of his own alleged fiscal prudence.
} 
implications. The budget could have been immediately offset if Council reversed some of the revenue streams Ford had cut in coming into office or raised property taxes in order to keep up with inflation. The fact remains however - as will be the subject of the next chapter - that more substantive funding arrangements and larger fiscal measures are required to address the city's revenue problem. Despite its limitations, the Miller-era Independent Fiscal Review Panel sought to kick-start such discussions. (Toronto, 2008; Stanford, 2008). The Fiscal Review Panel also addressed the structural problems of funding Canadian cities. Panel members argued that Canada needed a 'new deal' to improve funding for cities, particularly for large urban centres like Toronto. However, the key difference between Miller's Fiscal Review Panel and Ford's Core Services Review is that while the former acknowledged decades of provincial and federal downloading without matching fiscal supports, the latter has only sought to cut services and increase the use of private sector delivery. Moreover, with 40 percent of federal investments in cities set to expire in 2014 (due to the end of infrastructure funds), Toronto (like other cities) needs to secure higher levels of funding and shared-cost arrangements for social services and public infrastructure simply to keep-up with existing backlogs (Bradford, 2007). The Fiscal Review Panel argued that an established national cities policy, particularly for infrastructure, water, waste, sewage, transit systems, and extending to child and elder care and urban parks and recreation, could go a long way in beginning to rectify decades of chronic underfunding. The Core Services Review ignores the long-term picture by focusing only on cuts.

The embrace of the austerity agenda by Ford and Council, like Harper and McGuinty, make such a 'new deal' politically remote however. Indeed, whatever is the economic crisis of capitalism, the policy framework of neoliberalism is being remade to worsen the worst features of Toronto's fiscal and urban crisis. The Ford Administration is seeking to undermine public sector unionism in Toronto precisely because Toronto has been - and remains - one of the centres of North American 
unionism and class struggle (Kealey, 1995; Tufts, 2004; 2007). And because CUPE Local 79 is one of the largest and historically militant (along with Local 416) unions in Canada, extracting concessions would signal an open season for other municipalities and tiers of government. This is why Ford is being so aggressive with respect to layoffs, cuts in services, selling off assets and so forth. He has the support of Toronto's and Canada's ruling class. The ability of Mayor Ford and his political and corporate allies to take a hard-line posture with respect to workplace concessions in future rounds of bargaining, including the removal of job security provisions and efforts to further outsource employment, as much as the outcome of the Core Services Review, will be the test of the Ford agenda and whether conservatives can consolidate their hold over Council.

The political vacuum in the local state created by the retreat of the centre-left Miller Council has yet to be filled. It is not clear that the moral outrages at the cuts that have been the dominant political response of various communities and some unions will lead organizationally to anything more. A long period of stagnation could heighten the urban crisis and poorly-funded central cities like Toronto will continue their social polarization and decline (Hulchanski, 2010). The political coalitions that have been thrown up in Toronto to fight cuts over the last two decades have done little to reverse these processes. ${ }^{121}$ As the forthcoming chapter will argue, there needs to be more thinking about anti-capitalist alternatives unencumbered by the structural limitations and market imperatives imposed by capitalism. Some important initiatives such as the 'right to the city' campaigns are opening up such questions (Harvey, 2008). But only new organizational capacities will make such ideas politically viable.

\footnotetext{
${ }^{121}$ Although there are some important union-community initiatives happening in Toronto. The most notable of these are the ones located in the union movement: recent CUPE Local 79 and 416 campaigns for public services, Toronto Hydro workers fight against privatization, Toronto and York Region Labour Council support campaigns, and the Good Jobs For All Coalition (One Toronto, n.d.; Good Jobs For All Coalition, n.d.; TYRLC, n.d.). There are also community and other initiatives such as One Toronto, Ontario Coalition Against Poverty, Stop the Cuts and the Toronto Environmental Alliance-led efforts around waste privatization and TTC cuts and the Greater Toronto Workers Assembly's efforts around free public transit and public sector union support. More recently, the collective efforts of the Occupy Toronto protestors and collaboration with unions and social movement activists offers some promise, although it is still too early to tell (Vitullo and Scallen, 2011; Roslin, 2011; Mackeral, 2011).
} 


\section{Conclusion}

Since at least amalgamation in 1998 municipal workers in Toronto have been under pressure to forfeit concessions, increase "productivity" and expand the scope of market discipline. Mayor Lastman used the reduction in transfer funds as a political rationale to increase the pace of work amid attempts to privatize city services and assets. Rather than depart from the neoliberal project, the 'Third Way' progressivism of the David Miller regime infused selective progressive strands as a means to bolster competitiveness, enhance entrepreneurial opportunities and give the local government and businesses the "flexibility" to promote Toronto as a "global city." Mayor Miller justified the attacks against workers by arguing that the "world has changed" and that as a result of the recession extra-local and municipal pressures demanded austerity. This was most visibly apparent in the City's efforts to extract a host of concessionary demands by arguing that the availability of city services depended on wage restraint. While the 2009 civic workers' strike managed to achieve some minor increases in economic compensation, it was a significant political failure in its inability to draw connections between the attacks against public services and workers to tax shifting for competitiveness and chronic underfunding. Few connections were made between the defense of public sector workers and services and their relationship to the users of those services. These concerns could potentially have been framed as a clear political message arguing in favour of decent working conditions for all. Moreover, unlike the experiences of striking PSAC workers at Ottawa-Gatineau and CUPE Local 4600 in the run-up to collective bargaining at Carleton University, the Local 79 executive and, by extension, its members demonstrated an alarmingly ill-equipped response to the city's demands for concessions along with limited community support and solidarity

While some of this is certainly due to logistical issues related to the sheer size of CUPE Local 79, the union's executive committee bargained in almost complete isolation from the rest of 
the union. Equally important, despite the bitter lessons from the 2002 round of bargaining in which activist trade union members stressed the need for a politicized response, since then little was done to facilitate membership educational initiatives, build independent organizational capacities or foster a sense of collective unity. Such tasks cannot be accomplished overnight or at the calling of a strike, but requires a longer-term approach that stresses the political necessity of building active solidarity from the bottom-up.

These failures formed part of the backdrop leading to the election of an arch-conservative mayor and council, which ran on a platform explicitly announcing their intention to strip the city's unions of their hard won gains, privatize services and assets, and increase worker discipline. The implications for future rounds of bargaining seem bleak given the Ford Administration's avid insistence on the need to reduce the wages and size of the city's workforce, bring benefit levels down in line with the private sector and contracting-out employment. Looking ahead, if unions are to reappear as a movement and not simply hang on as a relic of the past, they need to move beyond the limited defense of their own members' interests and to those of the working class as a whole. But unions in any form are alone capable of resisting the coordinated push for austerity and hardening of neoliberalism. As I argue in the next chapter, doing so requires having feet both inside and outside the trade union movement, that is, rooted in an organizational form explicitly intent on building a broader working class movement across the many cleavages among workers. In other words, there needs to be a class-oriented unionism, as espoused by Marx and Engels, infused with a deep and critical analysis of (neoliberal) capitalism.

Given the historical and contemporary suspension of free collective bargaining and decades of attacks against workers' rights and freedoms, it is becoming increasingly clear that unions and oppressed persons generally can no longer, if they ever could, put their faith in the courts, laws or governments to enforce the postwar class compromise. For some three decades, labour and 
community activists have been unable to stop let alone reverse the progressive dismantlement of Keynesian-era social programs amidst an increasingly militant and recalcitrant state and capitalist class offensive. The attacks against the collective bargaining rights of workers, then, should unmistakably be understood as acts of class war. If the offensive is to be fundamentally countered a working class unionism must rekindle the struggle for realizing a world without capitalism. 


\section{Chapter 7 - Renewing Working Class Politics: Labour and the Struggle for Public Services}

This chapter begins with an exploration of the work of Marx and Engels in an effort to shed light on the progressive potential and political limitations of trade union organizing as an end in itself. Although trade unions emerged from the working class, they did not come to represent the interests of the class as a whole. Thus, while organizing workers at the point of production is not only important but necessary, I argue that in failing to come to terms with the root sectionalism of trade unionism organized labour risks impeding the formation of an alternative class project. No form of unionism alone can challenge the neoliberal program of austerity and retrenchment or the consolidated power of capital and the state. Therefore, it is my contention that should unions strive to regain their once prominent role in the pursuit of social justice and workplace democracy they need to take the risks of organizing working class communities and fighting back while they still have some capacity to do so or risk continuing along the several decade long union impasse and general decline in living standards. This necessarily requires an explicitly anti-capitalist ideological and political economic perspective, with the aim being to develop both alternative policies and an alternative politics rooted in the working class.

The subsequent section explores the shifting demographics of the Canadian labour movement. Over the period of neoliberalism the centre of gravity in the Canadian labour movement has increasingly shifted into the public sector and become feminized. This has reversed the longstanding pattern of militancy dominant in the private sector as public sector unions are increasingly at the forefront of workplace upheavals. But while strikes and other forms of labour protest are important, they rarely translate into a political and class-conscious movement beyond the immediate event. Paradoxically, despite a significant economic downturn that should have put labour and activists on the offensive, many are more atomized and alienated than ever. 
In fact, given historical patterns of wealth and income distribution, the class dynamics of the recession paints a vivid picture of who pays and who profits from austerity. Contrary to the claim that lower taxes on corporations and high-income earners generate enhanced private sector investments and higher public revenues, I show how over the period of neoliberalism quite the contrary took place. Private sector investments in new machinery and technology, for example, declined in lockstep with corporate taxes, while income polarization reached new heights. Thus I argue that private prosperity has come at the expense of public austerity. Rather than continuing along the path of neoliberal capitalism, I argue that a new historical project must be placed firmly on the agenda. While calls for enhanced "regulations" on capital are important, this often mistakenly assumes that states and markets are in opposition to each other. Absent the fundamental reorientation of the public sector as a whole these initiatives will remain incompatible with the logic of capital and therefore temporary and conjunctural at best.

Rather, what is fundamentally needed is to transform the whole banking sector into a public utility so that the distribution of credit and capital could be undertaken with democratically established principles. Because the public remains the lender of last resort and all persons require or deposit some form of their earnings in banks, there are few if any convincing reasons for private ownership of the banking sector. In addition to tightening financial regulations, then, I make the case that nationalizing parts of the banking sector could remove the institutional and financial infrastructure of capital, thereby enhancing democratic control and, potentially, serving as an example for other sectors of the economy. Therefore, in my view, only a class-based trade union movement that seeks to transcend the capitalist system may offer a way out of the crisis that is capitalism. 


\title{
Marx and Engels on the Progressive Potential and Political Limitations of Trade Unionism
}

For Marx and Engels the combination of workers represented an initial attempt on the part

of labour to collectivize their power and defend themselves against the imperatives of capital

\begin{abstract}
"The immediate object of trades' unions was therefore confined to everyday necessities, to expediencies for the obstruction of the incessant encroachments of capital, in one word, to questions of wages and time of labor. This activity of the trades' unions is not only legitimate, it is necessary. It cannot be dispensed with so long as the present system of production lasts. On the contrary, it must be generalized by the formation and the combination of trades' unions throughout all countries." (Marx, 1866, n.p.). ${ }^{122}$
\end{abstract}

While trade unions were important for sporadic and episodic "guerilla fights" between capital and labour, they argued that they were still more important as "organized agencies for superseding the very system of wage labour and capital rule." (Marx, 1866, n.p.). As such, in their view, the freedom of association to collectively bargain on behalf of and in accordance with other labourers was for them a fundamental potentiality that under definite social conditions embodied an emancipatory force capable of transcending social relations of servitude. As Engels (1845, n.p.) elaborated:

"[unions]... feel bound to proclaim that they, as human beings, shall not be made to bow to social circumstances, but social circumstances ought to yield to them as human beings; because silence on their part would be a recognition of the social conditions, an admission of the right of the bourgeoisie to exploit the workers in good times and let them starve in bad ones... But what gives these unions and the strikes arising from them their real importance is this, that they are the first attempt of the workers to abolish competition."

Because trade unions were among the first attempts by workers to abolish competition, Marx and Engels commended their demands for improved wages, workplace health and safety standards, a shorter working-day, an end to child labour, respect for prison labor, the collection of workplace statistics, union recognition and basic legislative safeguards. ${ }^{123}$ Accompanying the combination of workers, unions increasingly began developing a counter-culture of resistance that

122 Of course, such an assertion is in itself hardly revolutionary. But placed in historical context, apart from the aristocracy and bourgeoisie that were intent on restricting labours ability to unite, Marx and Engels encountered a good many radicals whom were also hostile, if not unsympathetic, of workers' rights to organize collectively. See Bakunin, 1990.

${ }^{123}$ Placing the context of growing labour activism in perspective, Engels $(1845$, n.p.) wrote: "It is, in truth, no trifle for a working man who knows want from experience, to face it with wife and children, to endure hunger and wretchedness for months together, and stand firm and unshaken through it all. What is death...in comparison with gradual starvation, with the daily site of a starving family, with the certainty of future revenge on the part of the bourgeoisie..." 
served as a guiding framework for programmatic demands, popular educationals and collective strategizing. Despite being separated by trade, language, skill, ethnicity and religion, many workers came together in makeshift community centres seeking to breakdown prescribed sociocultural, political and economic barriers. This included socializing at meetings and community events, sharing resources, experiences and collectively developing strategies for resisting management prerogatives. These 'labour temples', first in Europe and later in North America, were often built by volunteer and unemployed labour, and financed largely by individual donations (Eley, 2002; Kimeldorf, 1999; Lipton, 1973). The emphasis was on overcoming employer and state efforts intent on dividing and separating workers in order to socially and politically defeat them. For these reasons, Marx and Engels suggested that unions had the potential to become "schools of socialism." However, as these nodal points of community participation faded or were forcefully expulsed from view, often incorporated into official union structures or severely repressed by state and capitalist militancy, the sociocultural and political importance of organizing working class communities often faded from view.

While organizing waged workers at the point of production was necessary, Marx and Engels insisted that failing to carry such political momentum forward beyond the workplace could potentially impede future gains. This meant at every opportunity turning seemingly 'economic' advancements into political openings that could translate gains for a small number of workers into larger ones for the benefit of the class as a whole. But while craftsworkers and labour unions increasingly became larger and more organized, the failure to translate these gains to the nonwaged, particularly ethnic minorities and women, created cleavages among the working classes. Moreover, mistakenly assuming that basic workplace improvements and minor legislative changes would be continuous a good many unions increasingly eschewed efforts which helped their 
members understand the structure and dynamics of capitalism or how to develop the broader class capacities to challenge the state and capital.

For Marx and Engels this played a dual role. First, in fermenting internal working class resentment aimed at a so-called "labour aristocracy." And, second, in leading some unionized sectors into an alliance with capital and social democratic political parties in the hopes that such improvements would continue. This further atomized the working class as against the interests of capital. Rather than developing the capacities of union workers as class organizations, unions were increasingly becoming less "points of attack" or "agencies of organization" as they had hoped, than they were integrating the logic of capital into the process of production and trade union practices (e.g. tying wage gains to productivity increases and competition). In other words, although unions emerged out of the working class, they were not representing the interests of the class as a whole but rather the sectionalist interests of their own members. ${ }^{124}$ In narrowly devoting their energies to maximizing the value of their members' commodified labour power, unions were increasingly failing to come to terms with the systemic tendencies that progressively undermined the extension of those workplace gains to the non-unionized, unemployed and those who work but are not paid (i.e. domestic workers).

As a consequence, Marx and Engels became increasingly concerned with what they saw as the growing opportunism and trenchant economism of elected union officials. For instance, they wrote of "venal trade union leaders" who in finding employment within the liberal party were able to deliver working class votes. ${ }^{125}$ This worked to depoliticize the growing militancy of trade unions, while integrating workers into the dependent orbit of capital. Writing of the perverse ability of

\footnotetext{
${ }^{124}$ As Marx (1866, n.p.) put it, "Too exclusively bent upon the local and immediate struggles with capital, the Trades' Unions have not yet fully understood their power of acting against the system of wages slavery itself. They therefore kept too much aloof from general social and political movements."

${ }^{125}$ Reflecting on this point, Marx wrote: "When I denounced them [trade union leaders] at the Hague Congress I knew I was letting myself in for unpopularity, calumny, etc, but such consequences have always been a matter of indifference to me...in making that denouncement I was only doing my duty." (Marx, 1874, n.p.)
} 
political parties to draw votes from labour unions whose class interests were largely hostile to the party they were supporting, Marx and Engels anticipated to a significant extent the gradual integration, discipline and, when necessary, expulsion of the more militant and radicalized trade union activists. ${ }^{126}$

Lured by the competition for self-preservation among workers, trades unionists increasingly moved away from building the union as part of asserting the interests of the class as a whole and instead towards the preservation and betterment of their own memberships. This was accompanied by an increasing entanglement of labour unions with officially social democratic political parties that accepted the logic of capital and thereby an electoral landscape that marginalized extraparliamentary and extra-judicial actions in favour of incrementalism, unionism as an end in itself and liberal conceptions of rights and representative democracy (Kolasky, 1990; Penner, 1992; Bercuson, 1990; Upchurch et al, 2009; Carroll and Ratner, 2006). ${ }^{127}$

In their view, this depoliticized, even co-opted, form of trade unionism hindered the formation of an independent working class political initiative. In protecting their marginally advantaged tradecrafts at the expense of the unorganized and unwaged majority, unions were essentially paving the way for their own decline. Seeking to reorient and broaden the scope of trade unionism via a class unionism, Marx (in Lynd, 2001, p.53) argued:

126 "[Because] every class struggle is a political struggle...The organization of the proletarian into a class, and consequently into a political party, is continually being upset again by the competition between the workers themselves." (Marx and Engels, 2002, p.229).

${ }^{127}$ Writing in response to the development of social democratic trade unionism and the inability of unions to represent the class as a whole, Engels $(1871$, n.p.) wrote: "The trade-union movement, among all the big, strong and rich trade unions, has become more an obstacle to the general movement than an instrument of its progress; and outside of the trade unions there are an immense mass of workers in London who have kept quite a distance away from the political movement for several years, and as a result are very ignorant. But on the other hand they are also free of the many traditional prejudices of the trade unions and the other old sects, and therefore form excellent material with which one can work." Thus, they argued that the social democratic party-trade union nexus was rife with contradictions. Social democratic parties had no interest in challenging the logic of capital or the democratic limitations of the capitalist state. Moreover, trade unions were increasingly suffering from a lack of transparency between an elected and accountable executive and a disengaged rank and file membership. 
"The trade unions are an aristocratic minority. The poorer workers can not join them: the great mass of workers, driven daily by economic developments from the villages into the cities, remain outside the trade unions for a long time, and the poorest of all never belong to them. The same goes for the workers born in London's East End, where one out of ten belongs to the trade unions. The farm workers, the day laborers, never belong to these trade unions. The trade unions by standing alone are powerless - they will remain a minority. They do not have the mass of proletarians behind them..."

In other words, when unions focused almost exclusively on workplace gains, particularly those economic in nature, they oftentimes inadvertently aroused working class resentment. And while their gains often translated into legislative benefits for the non-unionized, these came to be associated with the party in power rather than the class struggles which led to their making. Moreover, these legislative gains would always be under attack, temporary and conjunctural. Marx and Engels argued that an overemphasis on individual union gains was a political trap because capital and the state promoted the view that "privileged" unionized workers gained at the expense of their non-unionized counterparts. Instead, they emphasized that neither protective legislation from the "great trade union of the ruling class" (i.e. the state), nor the resistance of the trade unionists alone abolished the main thing that had to be eliminated: "The capital-labour relationship, which the antagonism between the capitalist class and the wage-working class always generates anew." (cited in Lapides, 1987, p.161). For Marx and Engels, if trade unions were going to have a progressive future they needed to recognize that while they could bargain within the system they could not escape the political and economic contradictions that stymied their continual expansion owing to their class exploitation. The challenge before unions, then, was to simultaneously improve the working conditions of their members all the while extending those gains to the non-unionized and unwaged.

As long as capitalistic social relations were dominant and the imperatives of cut-throat competition, labour rationality and profit maximization the most essential features of society, Marx 
and Engels argued that the working class would remain in a position of modern-day serfdom. ${ }^{128}$

Thus they stressed that the labour movement alone was incapable of abolishing the root cause of the workers' distress. Unless unions made an effort to broaden their aims and advocate on behalf of and in accordance with all of society's oppressed (i.e. class unionism), unions risked degenerating into almost reactionary enclaves of privilege, upholding the manifest divisions of the working class and stunting its political potential. Rather than applying palliatives, trades unions must cure the malady: if unions were to become progressive forces of movement, rather than reactionary, even if defensive, opportunists, this meant building unions as expressions of working class unity. ${ }^{129}$

But of course this did not mean that unions should dogmatically assert the one 'right way' forward. ${ }^{130}$ Marx and Engels were vehemently critical of doctrinal sectarians and narrow-minded trade union leaders that sought to put their goals and ambitions above those of the working-class: "It is far more important that the movement should spread...than that it should start and proceed, from the beginning, on theoretically correct grounds. There is no better road to theoretical clearness of comprehension than by one's own mistakes durch schaden warden [to learn by bitter experience]." (Engels, 1866, n.p.). Instead the challenge facing trade unionists was to go about actively building the political and organizational capacities of not only its membership, but the class in its entirety. ${ }^{131}$

\footnotetext{
${ }^{128}$ Thus Marx and Engels emphasized the need to challenge the centrality of "wage-slavery." Certainly improved wages were important but would amount to little more than "better payment for the slave, and would not win wither for the worker or for labour their human status and dignity." (Marx, 2001, p.118-119).

129 "Apart from their original purpose, they [unions] must now learn to act deliberately as organizing centers of the working class in the broad interest of its complete emancipation. They must aid every social and political movement tending in that direction. Considering themselves as acting as the champions of the whole working class, they cannot fail to enlist the non-society men [the unorganized and unwaged] into their ranks. They must look carefully after the interests of the worst paid trades, such as agricultural laborers, rendered powerless by exceptional circumstances. They must convince the world at large that their efforts, far from being narrow and selfish, aim at the emancipation of the downtrodden millions." (Marx, 1866, n.p.)

${ }^{130}$ Extending their analysis to include intellectuals, professionals and party leaders, Marx (1879, n.p.) reminded: "The emancipation of the working class must be the work of the working class itself. We cannot, therefore, go along with people who openly claim that the workers are too ignorant to emancipate themselves but must first be emancipated from the top down, by the philanthropic big and petty bourgeois."

${ }^{131}$ As Marx (with guidance from Engels) wrote: "That the emancipation of the working classes must be conquered by the working classes themselves, that the struggle for the emancipation of the working classes means not a struggle for class privileges and monopolies, but for equal rights and duties, and the abolition of all class rule; That the economical subjection of the man of labor to the monopolizer of the means of labor - that is, the source of life - lies at the bottom
} 
As they argued in the Communist Manifesto: "The real fruit of their battle lies not in the immediate result, but in the ever-expanding union of workers. This union is helped on by the improved means of communication that are created by modern industry, and that place the workers of the different localities in contact with one another." (Marx and Engels, 2002, p.229-30). ${ }^{132}$ As Engels (emphasis added, 1881, n.p.) revealingly put it: "The trade unions ought not to forget that they cannot continue to hold the position they now occupy unless they really march in the van of the working class."

For Marx and Engels the recognition of the simultaneously classed, gendered and racialized underpinnings of production and reproduction were central to developing the political capacities of workers (Anderson, 2010). But while they emphasized the transcendence of class privileges, they were critically aware that intersecting axes of oppression would not mechanically be resolved with the abolition of class rule. They were apprehensive, however, about a politics based on differences alone and sought the means through which the diversity of the working class could be transformed via a class project that genuinely acknowledged and addressed these differences while recognizing their social and political interdependencies. ${ }^{133}$

of servitude in all its forms, of all social misery, mental degradation, and political dependence; That the economical emancipation of the working classes is therefore the great end to which every political movement ought to be subordinate as a means; That all efforts aiming at the great end hitherto failed from the want of solidarity between the manifold divisions of labor in each country, and from the absence of a fraternal bond of union between the working classes of different countries; That the emancipation of labor is neither a local nor a national, but a social problem, embracing all countries in which modern society exists, and depending for its solution on the concurrence, practical and theoretical, of the most advanced countries; That the present revival of the working classes in the most industrious countries of Europe, while it raises a new hope, gives solemn warning against a relapse into the old errors, and calls for the immediate combination of the still disconnected movements." And thereby declared: "That all societies and individuals adhering to it will acknowledge truth, justice, and morality as the basis of their conduct toward each other and toward all men, without regard to color, creed, or nationality; That it acknowledges no rights without duties, no duties without rights." (Marx, 1864, n.p.).

${ }^{132}$ In other words, despite important, even if short-lived, victories "it is necessary that our aims should be thus comprehensive to include every form of working activity." (Marx, 1871, n.p.).

${ }^{133}$ As Kevin Anderson (2010, p.244) has recently reminded, "Marx's mature social theory revolved around a concept of totality that not only offered considerable scope for particularity and difference, but also made those particulars - race, ethnicity or nationality - determinants for the totality." 
This is not the place for a detailed overview of debates about class, but a few general points are nevertheless necessary to emphasize. For Marx and Engels classes are not a thing, a partition where neatly demarcated typologies, iron-like, clearly separate the producers from the appropriators. Classes do not exist independent of the changing historical circumstances and social relations in which they arise. For Marx and Engels, the "Lazarus-layers" of the working class are constantly shifting and redefining themselves, displacing past relationships and recreating them anew. ${ }^{134}$ The concept of the working class never precisely delineated a specific body of people but was rather an ongoing expression for a social and historical process. Of course, in analytical terms the working class can be defined based on its relationship to the means of production and those who must sell their labour-power in order to live. But a broadly defined working class politics is about all labourers and their families, their paid and unpaid experiences, and the ways in which intersecting axes of oppression simultaneously influence other dimensions of social life (Roediger, 2005; Collins, 2003; Paap, 2006; Fletcher Jr. and Gasparin, 2008; Moody, 1988).

In other words, it is necessary to do away with the notion that class oppression is experienced only when one works for a wage or participates in paid employment. Rather class oppressions penetrate deeply into the very fabric of social life and includes the waged, unwaged and those denied a change to work because their skills are apparently unproductive or of inferior efficiency. Thus the working class is constantly changing not only in terms of how it sees itself but also in its relationship to others within the class. With this in mind, unions need to look beyond limited membership gains and seek to advance social and political ones that extend to the class as a whole. If organized labour is going to have a progressive future it will need to be anchored in a politics that orients its struggles toward the emancipation of the entire working class and therefore

\footnotetext{
${ }^{134}$ In other words, as Braverman (1998, p.282) argued more than three decades ago, "classes, the class structure, the social structure as a whole, are not fixed entities, but an ongoing process, rich in change, transition and variation, and incapable of being encapsulated in formulas, no matter how analytically proper such forms may be."
} 
the transcendence of class privileges. Certainly much has changed since the transition from Keynesianism to neoliberalism over the postwar period, let alone from the time of Marx's and Engels's writings until now. In what ways are Marx's and Engels's insights useful to today's labour movement, particularly public sector workers? How have compositional changes impacted the militancy of private and public sector trade unionists? And what challenges might this pose?

\section{Shifting Demographics and the Feminization of Organized Labour}

There have been major structural shifts to the composition of union membership by sex, age, industry and sector over the last thirty-odd years. Increasingly, public sector unionism has overshadowed private sector unionism in terms of both sheer density and militancy. Whereas public sector union density stayed relatively consistent from 1984 to 2003 hovering around 72 percent, total Canadian private sector density fell from 26 percent to just over 18 percent. By 2011 private sector union density had fallen to just 16 percent, while public sector density remained largely unchanged (Uppal, 2011, p.6). This has taken place in conjunction with a significant shift in the gender makeup of Canadian labour. From 1977 to 2003 women's share of unionization rose from just 12 percent to 48 percent (Akyeampong, 2004, p.5). And by 2011, more than 32 percent of women were unionized compared to just 29 percent of men (Uppal, 2011, p.6). These aggregate density measures, however, mask important differences for public and private sector workers. In the private sector, men's union density rates continue to outpace women (19 percent versus 12.5 percent), but the reverse is true in the public sector where women are concentrated in higher numbers (73.2 percent versus 68.5 percent). While public sector unionization rates have remained fairly consistent over the past three decades - buoying total union density (around 30 percent) private sector unionization has been nearly halved.

In Ontario, total union density has fallen from 37.6 percent in 1984 to just 26.6 percent in 2011 (second-lowest only to Alberta). Here too, total union density rates mask important differences 
between public and private sector work. While the former has stayed relatively consistent over the last three decades fluctuating around the 70 percent mark, private sector union density fell from 19.4 percent in 1997 to 16 percent by 2011 (ibid). Paralleling national trends, women continue to outpace men in the rate of unionization in the public sector, while men tend to predominate (although in much lower densities) in the private sector (HRSDC, 2012b; Uppal, 2011). ${ }^{135}$ In addition to the long-term gender and sectoral changes in union density rates, important changes in full-time and part-time work arrangements have also changed the distributional makeup of Canadian labour.

Between 1984 and 2002, full-time-equivalent union density has fallen from 45 percent to 33 percent, whereas part-time union density has remained stable around 24 percent (Jackson and Schetagne, 2003, p. 63). By 2011, the full-time rate of union density had fallen to 31 percent, while the part-time rate was 23 percent. However, among men part-time employees had a lower rate of unionization than full-time employees (18 percent versus 29 percent), while women's rates were slightly higher (25 percent versus 32 percent) (Uppal, 2011, p.9). By 2009 women made up 47 percent of the labour force and although more women worked part-time than men close to 73 percent of women who worked were full-time (Economic Fact Sheet, 2010, p.4). ${ }^{136}$

While women earned an average hourly rate equal to 81 percent of men's wages in 1998 by 2009 this had only risen marginally to 84 percent indicating an ongoing gender wage-gap. However, among full-time women who were unionized their wages were equal to 95 percent of men's wages,

\footnotetext{
${ }^{135}$ There are few studies examining the union density rates of municipalities and even fewer disaggregating public and private sector union rates. Research from Jackson and Schetagne $(2003$, p.57) estimate that the Toronto census metropolitan area has a total union density rate of roughly 22 percent, well below the Canadian average.

${ }^{136}$ Research by Marshall (2011, p.13-14), shows that the employment rate between men and women is converging. Whereas in the 1980s men's labour force participation rates were 12 percent higher than women, by 2010 the gap had fallen to less than 3 percent. Likewise, although women continue to do the majority of unpaid domestic labour, Marshall's data suggests that time spent on domestic labour and childcare rates are becoming increasingly similar between spouses in Canada. A parallel narrowing of the housework gap has been found among teenage boys and girls. On the whole, progressively, from late baby boomers (those born between 1957 to 1966) to Generation X (born between 1969 and 1978) and those in Generation Y (born between 1981 and 1990), there has been an increasing similarity in men's and women's involvement in paid employment and housework.
} 
while unionized part-time women earned an average of 8 percent more (Uppal, 2011, p. 10; Economic Fact Sheet, 2010). Thus the evidence suggests that unionization plays a far greater role in reducing gender-based wage discrimination, including improving non-wage related issues such as unpaid leave, sick pay, maternity/paternity benefits and health and safety concerns than equityseeking legislation does (Jackson, 2005). In addition to being concentrated in the public sector and in greater numbers among full-time workers, recent data also suggests that unionization is increasingly associated with older and higher educated workers. In 2011, 36 percent of workers aged 45-54 were unionized compared with only 14 percent of those aged $15-24$, with marginal increases the further one goes up the distributional ladder (HRSDC, 2012b, p.8). There has also been a significant domestication of trade union organizations. For instance, in 1962 international (largely U.S.) unions accounted for two-thirds of all Canadian union members, but by 1995 this number had dropped to 29 percent. Over the same period, national union representation has risen from 21 percent to 57 percent (Akyeampong, 2004, p.7). By 2010 the share on international unions in Canada had fallen to 27 percent, while Canadian-based unions rose to 67 percent (HRSDC, 2010, p.14). Much of the shift from international to domestic unions has had to do with the booming unionization of the public sector in conjunction with the decline of the goods-producing sector unionization through this period as capital restructured and relocated to the global south.

Today public sector unions are the first (Canadian Union of Public Employees: 601, 976), second (National Union of Public and General Employees: 340,000), sixth (Public Service Alliance of Canada: 188,462), eighth (Fédération de la Santé et des Services Sociaux: 122,193) and tenth (Service Employees Internal Union: 92,781) largest of all Canadian unions. While some of these unions are certainly branching out into the private sector, their members remain largely concentrated in the public sector. Put differently, public sector unions today represent nearly 60 percent of total union coverage in Canada (HRSDC, 2010, p.14). By 2011 just nine of the ten 
largest unions covered 50 percent of all trade unionists in Canada. ${ }^{137}$ This suggests, paradoxically, a concentrated yet highly fragmented representational structure. Because working people associate themselves with a number of identificational forms, such as race, gender, ethnicity, sexuality, language and so forth, the identification of ones subjectivity with their class identity is a process of politicization. But while the sectoral composition of labour has changed, has this resulted in a corresponding wave of trade union militancy or identification with one's class interests?

In terms of trade union militancy - a rough gauge of workers' confidence in collective action - the responses since the 1990s have been generally mild in comparison with previous decades of workplace discontent. Where such stoppages have centred has also shifted. From 1970 to 1981, the data reveals a particularly heated decade of trade union militancy. But since then the number of strikes, workers on strike and work days lost to strikes has declined in lockstep. Research suggests moderate and declining levels through the 1980s and a sharp drop in the 1990s and continuing through the 2000 s (Gunderson et al, 2005). ${ }^{138}$

Figure 1: Labour Militancy in Canada, 1960-2004 (Briskin, 2010, p.222)

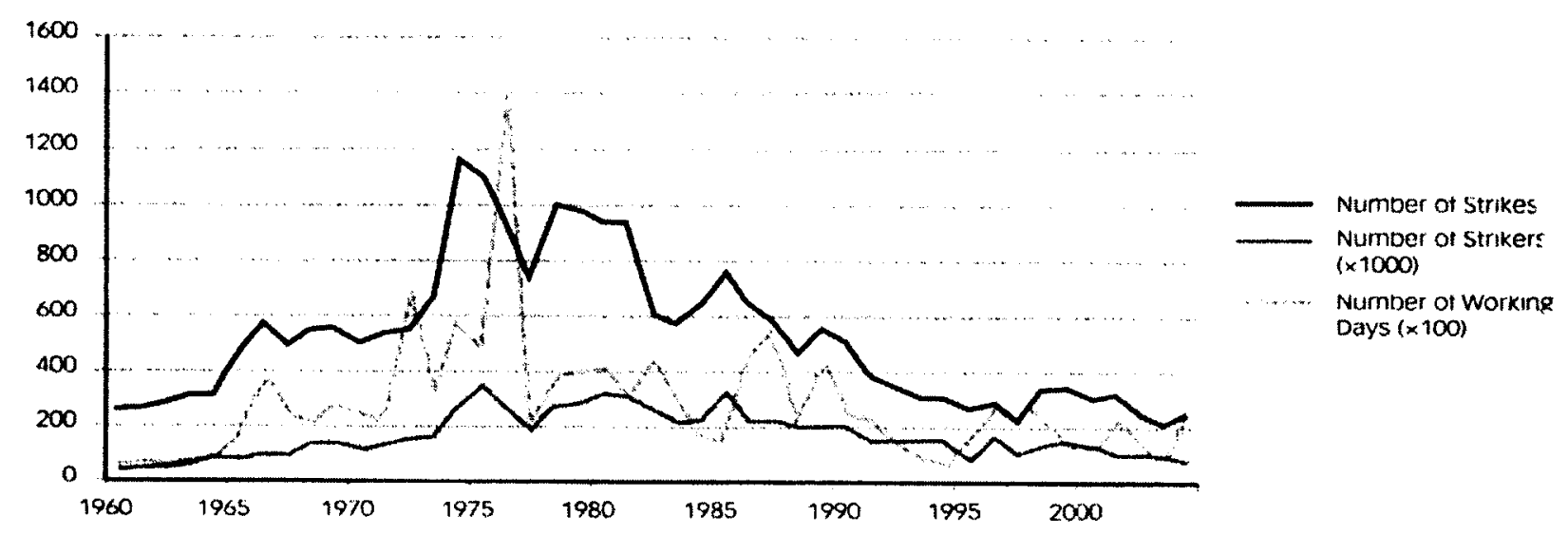

Source: Workplace Information Directorate, Human Resources and Social Development Canada.

${ }^{137}$ All of these unions have over 100,00 members. Another 42 percent of trade unionists are in unions with more than 10,000 members but less than 100,000 , while the remaining 8 percent are in unions averaging around 2,000 workers (HRSDC, 2010, p.14; HRSDC, 2012b, p.1).

${ }^{138}$ The highpoint of worker involvement in strikes was 1976 when strikes involved some 18 percent of total employment. Since 1999, they have dropped to about 1 percent of total employees (Briskin, 2010). 
Perhaps more tellingly, however, the data also reveals an important shift away from the long-established dominance of private sector trade union militancy.

"Even though many public-sector workers are deemed essential, denied the right to strike, and possibly legislated back to work, between 1995 and 2004, 27 percent of all stoppages (787) were in the public sector (the highest percentage since public-sector unionization). The stoppages involved more than 71 percent of all workers on strike. Furthermore, in this period, almost 20 percent of all work days lost were in the public sector" (Briskin, 2010, p.223). ${ }^{139}$

Comparing the period 2001-2005 to 2006-2010, federal work stoppages declined from 4 to 2 , while provincial work stoppages declined from 32 to 17 . There has also been a considerable fall in the average number of workers involved in major work stoppages: a decrease of 91 percent in federal jurisdiction and 68 percent in provincial jurisdiction over the same periods (HSRDC, 2010, p.16). Overall, the average number of workers involved in major work stoppages has also declined significantly, although with important variations in the public and private sectors.

Figure 2: Sectoral Strike Activity, 1960-2004 (Briskin, 2010, p.223)

\begin{tabular}{|c|c|c|c|c|c|c|c|}
\hline \multirow[b]{2}{*}{ Year } & \multirow[b]{2}{*}{ Secturr } & \multicolumn{2}{|c|}{ Number } & \multicolumn{2}{|c|}{ Workers } & \multicolumn{2}{|c|}{ Work days lost } \\
\hline & & $\#$ & $\mathrm{gin}$ & $\#$ & $\%$ & $\#$ & S/ \\
\hline \multirow{3}{*}{$\begin{array}{l}1960- \\
1944\end{array}$} & Public: & 3751 & 17.8 & $5,177,586$ & 470 & 77.634 & 11.8 \\
\hline & l'nuate & 17310 & 82.2 & $5,8.31,247$ & 53.0 & 582,706 & 88.2 \\
\hline & Totral & 21061 & 100.0 & $11,008,833$ & $\ln .0$ & 660,3413 & 100.0 \\
\hline \multirow{3}{*}{$\begin{array}{l}1945- \\
2004\end{array}$} & Public & 787 & 27.3 & $1,334,162$ & 71.7 & 24,392 & 19.5 \\
\hline & Private & 20196 & 72.7 & $526, .143$ & 28.3 & 100,376 & 80.5 \\
\hline & Total & 2883 & 100,0 & $1,860,5015$ & 100,0 & 124,708 & 1400,0 \\
\hline \multirow{3}{*}{$\begin{array}{l}19 \mathrm{hO}- \\
2004\end{array}$} & Public & 4538 & 19.0 & $6,511,748$ & 50.6 & 102,026 & 13.0 \\
\hline & Private & 19406 & 81.0 & $6,757,590$ & 49.4 & $68.3,082$ & 87.0 \\
\hline & Toral & 23944 & 100.0 & $12,869,338$ & 1101.0 & 785,108 & 100.0 \\
\hline
\end{tabular}

Source: Wirk Stuppage Data, Wirkplace Infurmatiun Dircceurate, Human Reviurces and Sincial Derelopment Canada.

Women have not only been instrumental to the increasing militancy of public sector unions, but at the forefront of militancy in their legal and extralegal forms. As Briskin $(2010$, p.219) has argued: "Women have promoted women's leadership, challenged traditional leaderships to be more accountable, encouraged unions to be more democratic and participatory, organized networks of

${ }^{139}$ Gunderson et al, 2005 suggests this number may actually be even higher when contracts settled through direct legislative intervention and those denied the right to strike are included. 
women's committees to represent their interests, and pressured unions to take up women's concerns as union members and workers - through policy initiatives and at the negotiating table." The average duration of strikes also reveals some important insights. Comparing 2001-2005 to 20062010, the average duration of major work stoppages in federal jurisdiction dropped from 50 to 13 person-days not worked, whereas this increased from 20 to 24 for workers under provincial jurisdiction (HRSDC, 2010, p.10). From 2005 to 2010, 90 percent of all work stoppages occurred under provincial jurisdiction. Part of this is explained by federal devolution onto the provinces which, despite delivering the bulwark of services, had their revenue drastically reduced in the form of transfer payments. On the whole, from 2000 to 2011 the total yearly amount of workplace stoppages four times reached new all-time lows, while the total yearly amount of person-days not worked twice reached new all-time lows.

Over the same period, workers under provincial jurisdiction six times reached new all-time low workplace stoppages, while setting a new yearly low for the total number of person-days not worked (HRSDC, 2012, n.p.). When disaggregating these stoppages, it is revealed that from 1960 to 1994 educational services, healthcare, social assistance and public administration accounted for about 7 percent of all strikes and 14 percent of all striking workers. Between 1995 and 2004, however, these sectors had come to represent 17 percent and 38 percent indicating growing public sector militancy in the context of industrial conflict (Briskin, 2010, p.224). Moreover, public sector strikes tend to involve much larger numbers and be shorter in duration, whereas private sector strikes have fewer workers and are longer in duration. But what does militancy actually reveal? Is militancy alone indicative of trade union offensives, defense struggles or growing awareness of class consciousness?

While strikes can be explosions of class consciousness the working class solidarity they generate rarely gathers momentum beyond the immediate event (Mann, 1973). Hence while strikes 
may lead workers to question the unequal relationship between employers and employees, those concerns rarely translate into a coherent awareness of class differences and class struggles, let alone critical assessments of deficiencies in the political structure or capitalist system. The experiences of museum workers, teaching assistants and contract instructors, and civic workers seem to confirm Mann's hypothesis. Even the bald-faced bail-outs of the banking industries and automotive sectors buttressed by new forms of corporate welfare did not polarize class consciousness.

Militancy alone rarely accomplishes much beyond occasional bursts of discontent. While strikes are certainly important and can go a long way toward galvanizing broader community support in defense of decent jobs, legalistic straightjackets and authoritarian employers, they rarely translate into a clear ideological opposition and political perspective. In fact, although the centre of gravity in the Canadian labour movement has shifted into the public sector, in the absence of a unified pushback against neoliberalism, the drive to austerity may expose the labour movement as a paper tiger (Gindin, 2010). Because workers are not inherently radical or conservative but adapt to the structured options they face, any process of radicalization will inevitably be uneven and fraught with ongoing tensions as diverse interests, levels of class consciousness, experiences and political preferences come into play. Unless unions develop the capacities to challenge their class subjugation they will continue to face both resentment from the unorganized sectors of the working class as well as mounting pressures from capital to rescind past achievements.

From the case studies explored in this thesis, far from creating a crisis of neoliberal legitimacy (or capitalism) the capitalist classes have emerged emboldened in the midst of the Great Recession. Ironically, despite a significant economic downturn that should have put labour and activists on the offensive, many are more atomized than ever. It is my contention that should unions strive to regain their once prominent role in the pursuit of social justice and workplace democracy they need to take the risks of organizing working class communities and fighting back while they 
still have some capacity to do so or risk continuing along the several decade long union impasse and general decline in living standards. But unions are paradoxical institutions:

\begin{abstract}
"While they are an effective vehicle to advance workers' interests, they have also become a force for accommodating workers to corporate capitalism...Unions emerged in response to alienation and exploitation, but collective bargaining, the defining characteristic and essential function of unions, takes as given the prevailing power relations at the workplace...At best, unions nibble away at the margins of power, modifying but not altering in any fundamental sense relations of domination and subordination. And since capitalist power is at the heart of alienated and exploited labour, unions are not in a position to offer real solutions to these conditions. This does not alter the fact that, in capitalist society, unions constitute critically important organs of struggle and are still the only viable means most workers have to realize better lives on and off the job." (Rinehart, 2006, p.203-4
\end{abstract}

In seeking to expand alternative viable means of trade union organization, academics, trade unionists and activists have generally converged on three points: (1) issues related to union bureaucracy, transparency and calls for deeper democracy; (2) the need to avoid economism and include issues related to workplace harassment and gender/racial oppression; (3) and a focus on increasing militancy and developing social movement coalitions. ${ }^{140}$ Others have engaged in a lively debate as to what such forms a militant, grass-roots unionism might take (Kumar and Schenk, 2006; Tait, 2005; Turner et al, 2001; Brofenbrenner et al, 1998). And while all of them are important, have much to offer and require further debate, what is often missing or treated as secondary is the general crisis of political strategy pervading the labour movement as a whole. That is to say, strategies and tactics not only exploring how to develop the capacities of their members to defend past gains and advance new ones, but how to go about extending those gains to the non-unionized and unwaged workers within an explicitly anti-capitalist context.

This needs to be placed front and centre of such analyses and necessarily requires developing a broader ideological framework in which to anchor political ambitions. Given the onslaught of neoliberalism and a reinvigorated austerity agenda, only a radicalized anti-capitalist trade union movement may be able to stem or reverse their decline. Thus understanding the capitalist context that leaves workers dependent on the imperatives of capital is crucial to

\footnotetext{
${ }^{140}$ For typological overviews see Albo and Crow, 2008; as well as, Ross, 2008; Camfield, 2008.
} 
developing a political program capable of challenging the power of capital. The problem is "Capital does the investing, organizes production, manifests the application of science and technology, provides the jobs, and generates the growth and tax revenue for social programs and public employment. The understandable inclination of workers with only their labour power to sell is to accommodate to this naturalized mechanism to meet their needs" (Gindin, 2012, n.p.). ${ }^{141}$ While the power of unions lies in their willingness to act collectively in the interests of its members, unless the root sectionalism of labour is addressed renewal efforts are unlikely to be successful.

In order to reverse the cumulative defeats which have befallen unions over the era of neoliberalism, a renewed labour movement - in addition to reclaiming strikes, sit-ins, work-to-rule campaigns, mass secondary picketing, workplace takeovers and sustained general strikes - must come to terms with the way capitalism permeates all avenues of peoples' lives. The inability to cultivate an anti-capitalist class-consciousness and concrete relationships between workers and their communities, has played a significant role in augmenting class fragmentation. Rather than fighting their true enemies - the capitalist class and state which supports them - the tendency among the working classes has been to fight the enemies of their enemies. ${ }^{142}$ This is a common and widespread phenomenon. How can public sector unions demand a pay raise when the private sector is getting battered? Is this why taxes keep getting raised? Are unions to blame for a particular company moving elsewhere to take advantage of "competitive" wages? It is often claimed that unionized workers should be happy they have a job at all; "someone who's unemployed will do it for half the wage." This fragmentation is not without cause. As Lebowitz (2003, p.122) has reminded, a "necessary condition for the existence of capital is the ability to divide and separate workers - in

\footnotetext{
${ }^{141}$ It is for these reasons that Marx (1865b, n.p.) and Engels stressed that: "Instead of the conservative motto, a fair day's wage for a fair day's work, they [unions] ought to inscribe on their banner the revolutionary watchword abolition of the wage system."

${ }^{142}$ As Marx and Engels put it: "At this stage, therefore, the proletarians do not fight their enemies, but the enemies of their enemies, the remnants of absolute monarchy, the landowners, the non-industrial bourgeois, the petty bourgeois." (Marx and Engels, 2002, p.229.)
} 
order to defeat them. Rather than a contingent, incidental characteristic...this is an inner tendency of capital."143 In other words, given the structural antagonism central to the production and reproduction of social life, only clearly articulated political messages rooted in an understanding of capitalism's inner processes may stem or reverse the tide of (neoliberal) capitalism.

Related, because Canadian labour is generally older, suggesting that union representation was inherited rather than explicitly fought for, a class perspective must be regenerated in order for unions to come to terms with how to renew themselves as a social force. Beyond episodic displays of labour's potential, most clearly demonstrated during mass job actions, it is unlikely that labour will be able to remake itself without a simultaneous renewal of the anti-capitalist left. As Workman (2009, p.130) has argued: "Without an enriching dialogue about capitalism in Canada, an informational network that counters the nonsense of the nightly news, a working-class culture that affirms the insights and experiences of working people and the coherent resistance of organized labour, all we are left with is a diverse collection of issue-based, resource-poor, small-scale organizations biting at the heels of the corporate Leviathan." To put it differently, unions remain trapped in the past and unprepared for the present - continuing to defend members' hard-won previous gains, yet unable to come to terms with the changed political-economic circumstances that demands a radicalized approach if unions are to renew themselves. To be radical is to get to the root of the problem and only such a process of radicalization offers an opportunity to resist the imperatives of the capitalist system.

\footnotetext{
${ }^{143}$ Or as Marx (in Anderson, 2010, p.20) argued: "This antagonism among the proletarians of England is artificially nourished and kept up by the bourgeoisie. It knows that this split is the true secret of the preservation of its power."
} 
Building on worker dependency and union sectionalism, and absent collective identities and alternatives:

"working families found individualized ways of 'getting through' that reshaped working class consciousness and contributed to the reproduction of a neoliberal ethos. Working hours increased dramatically, young workers stayed at home longer, married couples moved in with their parents to save for a mortgage, credit cards became ubiquitous, and families increased their debt loads. Housing became an asset to be borrowed on; stock markets were anxiously watched for their impact on pensions; and tax cuts were welcomed as the equivalent of wage hikes." (Gindin, 2012, n.p.)

Because neoliberalism not only subjugated and attacked working people but integrated and built upon workers' social interdependencies, a successful project for union renewal inevitably requires a reconfigured emphasis on working class politics. As part of this process a renewed left would need to have connections both inside and outside of the labour movement and seek to link these issues across workplaces, engage in political debates and agitate across communities. This requires simultaneously working to build the capacities of the entire union to fight back against concessionary demands; developing a movement inside the union that pushes for enhanced democratic participation and control; a radically feminist, antiracist, class struggle-oriented political praxis that engages with the struggles of the broader community; and educational efforts intent on building a cadre of workers and activists that embody intellectual understanding and are active.

Considering the weak state of anti-capitalist forces and labour in Canada and their inability to translate support for their political positions into commensurate political influence, new autonomous political mobilizations that challenge the rule of capital are gravely needed. One such innovative form is that currently under development by trade unionists and social justice activists in Toronto working together to build a broad anti-capitalist organization. The objective of the Greater Toronto Workers' Assembly is to sustain a process, not to launch a ready-made organization (Rosenfeld and Fanelli, 2009). Its importance, however, lies not so much in what it has materially been able to accomplish but in its emphasis on trying to bring together the strongest elements of the trade union movement, community organizations, and political parties from the bottom-up. In this 
regard, the Assembly is important because it seeks to attract new people to an exciting project with new possibilities outside of the traditional trade union movement; it conveys to progressive individuals in union locals that there are spaces outside but connected to labour fighting for decent working conditions and social justice; exchanges energies between labour and community activists by learning how to work collectively and democratically among diverse sections of the workingclass; and rejuvenates already existing movements while launching new anti-capitalist ones (ibid). While the Assembly is one very preliminary example of a new organizational form seeking to transcend the limitations of trade unionism, it is certainly not the only one (Fletcher Jr. and Gasparin, 2008). Despite new and creative ways of resisting a reinvigorated austerity agenda, the capitalist class continues to profit exorbitantly on the backs of working people through the crisis. And because class is relational and not gradational, this exploitation occurs at the expense of others. Thus it is important to examine who the austerity agenda will most benefit and most harm as unions and the working class continues to come under attack.

\section{Private Prosperity: Who Profits?}

One of the gross indicators of expanding class disparities is the distribution of wealth and income. For example, the share of Canadian families with after-tax incomes from 75-150 percent of the median after-tax income fell from 52 percent in 1989 to 47 percent in 2004. At the same time, the share of persons with after-tax incomes below 75 percent of the median rose by 2.6 percent, while the share of income above 150 percent rose 2 percent. This reveals a trend away from middleincome earning families toward both higher- and lower-earning families and individuals. ${ }^{144}$

\footnotetext{
${ }^{144}$ The author of this study has noted that this increase occurred at the same time as a reduction in several transfer programs, such as Employment Insurance and social assistance rates, including reductions in corporate and personal incomes, which has weakened the overall redistributive role of the Canadian state (Heisz, 2007). It is also worth noting that a number of studies have shown that once a basic material standard of living is achieved, the importance of expanding personal income decreases in importance as other aspects of life, such as happiness, community involvement, altruism, physical activity, friendship, intellectual pursuits, and self-esteem for example, take greater precedence (Perelman, 2011; Frank, 1999; Lane, 1991).
} 
Over the period of neoliberalism, the average Canadian has not seen any real growth in income once inflation is taken into account. In 1978 median Canadian family income was about $\$ 48,000$ (in 2011 dollars) but by 2008 it had declined to $\$ 46,700$ (McQuaig and Brooks, 2011, p.xvi). Nearly all income growth over the last thirty years has gone to the top ten percent of incomeearners and especially the top 1 percent and 0.1 percent. In the 1970 s, the wealthiest ten percent of the population received 23 percent of total market income. This increased to 28 percent by the 1980s and 37 percent by the 1990s. By 1999 the wealthiest ten percent of families held 53 percent of the wealth in the country. Furthermore, between 1970 and 1999 their average wealth increased by 122 percent, while the poorest ten percent saw a drop of 28 percent. As a result, in 2009 income disparities had reached levels unseen since the 1920s (Yalnizyan 2010, p.3-4). Whereas Canada's richest one percent took home less than eight percent of total income in the 1960s this had reached 14 percent by 2007. As such 32 percent of all growth in incomes from 1997 to 2007 went to the top 1 percent.

A significant contributing factor has been the regressive overhaul of the Canadian tax system. Between 1992 and 2004 the effective tax rates paid by the one-thousand highest-earning Canadians dropped from 42 percent to 31 percent (McQuiag and Brooks, 2011, p.178). While in 1948 the top marginal tax rate for those making $\$ 250,000$ ( $\$ 2.37$ million in today's dollars) was 80 percent, the top tax rate in 2009 averaged across Canada was 42.9 percent for income above $\$ 126,264 .{ }^{145}$ Even in the depths of the Great Recession, Canada's 100 top-earning CEO's earned around 155 times more than the average Canadian. But this excludes some $\$ 1.3$ billion in unused stock options (Stanford, 2010, p.4). And when they do exercise those stock options, Canadians will

\footnotetext{
${ }^{145}$ By 20093.8 percent of Canadian households controlled $\$ 1.78$ trillion in financial wealth or 67 percent of the Canadian total (ibid). Meanwhile, from 1999 to 2009 the number of Canadian billionaires had doubled from 25 to 55 . The top 0.1 percent now take home 3.1 percent of national income, surpassing the pervious high of 1.9 percent in 1933 (McQuaig and Brooks, 2011, p.xviii). While the income of median Canadians has stagnated, the richest 0.1 percent of Canadians' incomes have increased by $\$ 4.8$ million.
} 
subsidize high-income earners in excess of $\$ 360$ million in lost tax revenue as capital gains are taxed at nearly half the rate of ordinary income. ${ }^{146}$ The rise of excessive CEO pay is of recent vintage. In 1995 the top ten earning CEO's took home $\$ 60$ million in compensation but just 12 years later this had risen to $\$ 330$ million (a 500 percent increase!) (McQuaig and Brooks, 2011, p.9) ${ }^{147}$ All in all, between 1998 and 2008 Canadian CEO compensation had outpaced inflation by a whopping 53 percent (Mackenzie, 2010; ibid).

As a result of tax cuts enacted between 2001 and 2010 finance and insurance industries will benefit to the tune of $\$ 4$ billion in annual savings. Tax cuts through 2012 will bring this subsidy to $\$ 6.1$ billion a year (Sanger, 2011). Indicative of the growing power of finance capital in Canada, since 2000 financial sector stocks have had a 5.7 percent higher annual return than non-financial stocks. Today the financial sector controls an estimated 20 to 30 percent of the capitalization on the Toronto Stock exchange (Sanger, 2011, p.4). Since 2001 Canada's financial sector has been growing at twice the rate of the rest of the economy and has almost doubled since the 1980s. As a result, the Canadian financial industry is now nearing 8 percent total share of the economy - similar to the share of the financial sector in the U.S. right before it imploded.

A contributing factor to the growing power of finance in Canada stems from deregulatory changes enacted in 1987 which allowed chartered banks to buy and own brokerage firms, something that they had previously been forbidden to do (Livesey, 2012). Rather than investing the excess cash

${ }^{146}$ The reduction to capital gains (about half of which are enjoyed by the wealthiest 1 percent) in 2000 alone saved the richest Canadians close to $\$ 8$ billion in a little over a decade. In 1991 only about one-third of Canadian top 100 public corporations were using this method of compensation but by the end of the decade they all were. The changes allowed the profits that executives received through stock options to be taxed as capital gains. This created perverse incentives for CEO's to push up the stock in the short-term and engage in riskier and more speculative activities. See, McQuaig and Brooks, 2011.

${ }^{147}$ Additional research by Lars Osberg $(2012$, p.10) found that over the last thirty-three years, only the top 20 percent have seen an increase in their real incomes. In Canada, the income share taken by the top 1 percent fluctuated around 15-17 percent in the 1920s and 1930s, but dropped to the 10 percent range during WWII followed by thirty years of consecutive declines bottoming-out at 7.2 percent in the late-1970s. However, this was not due to any significant marked depreciation in their rates of profit but rather the income distribution of everyone else rose faster. Since the 1980 s, though, the top 1 percent of the capitalist class has been able to regain lost ground taking in 12 percent of total income by 2007. Hence, Osberg concludes that most of the income-gains from macro-economic growth have been reaped by a very small percentage of the income distribution. 
into productive "real" activity, banks increasingly turned to solidifying their power through mergers, acquisitions, speculative investments and share buybacks. In 2010, bonuses paid to Canada's six largest banks reached a record $\$ 8.9$ billion before setting a new all-time high in 2011 with $\$ 9.5$ billion. A Conference Board of Canada (cited in Livesey, 2012, p.19) report found that directors compensation jumped 33 percent in the nadir of the recession between 2008 and 2010. Finance has increasingly eclipsed manufacturing growing from less than 12 percent of total Canadian GDP in 1950 to more than 20 percent by 2010 , while manufacturing declined from 30 percent to 13 percent over the same period (Livesey, 2012, p.35).

In Toronto alone more than 300,000 workers are concentrated in the financial services industries (Heinrich, 2012). Indeed, a Toronto Life (Preville, 2009, n.p.) article recently boasted that one-third of the city's lawyers and accountants work for the financial sector in some form. Uncritically advocating for a finance-led future, Toronto Life went on to argue: "In the new economy, Ontario doesn't make stuff anymore. We let other places do that; our new job is to lend, invest, and manage people's money." With Toronto's financial sector expected to overtake London as a hub for bankers by 2020 , the growing impunity of investment fraudsters speaks volumes about the growing power and influence of finance capital more broadly (Henireich, 2012; Livesey, 2012). Adding to the problem is the fact that many Canadians' general financial and investment knowledge is limited. ${ }^{148}$ With all of this in mind, there is a blatant contradiction in employer demands for concessions amid ongoing forms of corporate welfare as workers are asked to take pay cuts and service levels are reduced. Clearly, as the public policy responses by the governments of Harper, McGuinty and Miller/Ford have shown, despite significant profit rates the state continues to take a

\footnotetext{
${ }^{148}$ A 2009 Canadian Financial Capability Survey by Statistics Canada found that Canadians received an average grade of 67 percent (Keown, 2011, p.30). The financial survey questionnaire also found that those with higher-incomes and education scored much higher than the mean, while immigrants and lower-income earning Canadians scored lowest.
} 
leading role in creating new profit-making opportunities for capital and disciplining workers. ${ }^{149}$ So have neoliberal-inspired tax cuts delivered on their promises of increased investment, research and development? Have workers benefitted through increased wages and more secure forms of employment?

Unsurprisingly, the answer is no. Research by Jim Stanford (2011) has shown that "Since the first of several rounds of business tax reforms and reductions were implemented in 1988, business investment has declined by 1 full percentage point of GDP - even though after-tax business cash-flow has increased (in part as a direct result of the tax reforms) by 3 to 4 percentage points of GDP." Stanford's study shows how changes in tax rates have had little if any statistically significant impact on business investment. Indeed, since 2001 Canada's most profitable corporations have been sitting on close to $\$ 750$ billion in uninvested cash-flow thus leading Stanford (Stanford, 2011, p.4) to conclude: "As a means of stimulating growth, employment and even private business spending the historical evidence suggests that business tax cuts are both economically ineffective and distributionally regressive." 150 These findings were supported by Valiani (2012) whose found that as corporate taxes were reduced over the period of neoliberalism, particularly since the Mike Harris cuts but continuing with the McGuinty reductions, the Ontario economy underwent falling or stagnant production levels and decreasing employment. Corporate profits, however, remained very healthy. As a result, in her view, rather than increasing employment

\footnotetext{
${ }^{149}$ The Canadian Labour Congress has recently estimated that a 1 percent cut to corporate tax rates reduces annual public revenues by about $\$ 2$ billion. In 2010 alone, companies saved roughly $\$ 3.3$ billion in federal corporate taxes due to the fact that nearly half of their earnings were taxed as capital gains (CLC, 2012, p.4). Likewise, Canada's largest corporations benefited from $\$ 3.5$ billion in state-sponsored research and development subsidies, while the special lowtax rate for small businesses cost $\$ 3.9$ billion.

${ }^{150}$ Stanford's study is supported by similar findings by the Canadian Labour Congress $(2012$, p.10), which found that instead of using the extra-cash to boost investments in machinery, equipment and new plants, nearly half of all profits have gone to boosting shareholders dividends. The top ten corporate hoarders were holding some $\$ 30.7$ billion in extra short-term and long-term assets between 2000-10, while total corporate cash reserves for private and non-financial corporations reached $\$ 477$ billion (CLC, 2012, p.5). Like Stanford, the CLC's research shows that the rate of investment in machinery and equipment over the past decade has declined in lockstep with lower tax rates.
} 
and production, lower corporate and income taxes have augmented precarious employment for most workers and increased the wealth of the well-to-do. ${ }^{151}$

In tandem with lower taxes, public investment as a percentage of GDP fell from an average of 2-3 percent in the 1960s and 1970s to around 0.5 percent by the mid-1990s and have remained there since (Loxley, 2010, p.4). During this time, total federal taxes as a percentage of tax revenues from corporations dropped from 20.9 percent to 15.9 percent (a drop of nearly 24 percent). Partially filling that gap was an increase in the share of total federal taxes as a percentage of tax revenues collected from individuals, which rose from 46 percent to 52 percent. Put differently, today for every dollar of revenue the federal government receives 48 -cents comes from individual taxation and only 13-cents from corporations (OECD, 2011). This is a significant reversal of taxation policy since the 1970s. Therefore, while corporations reap extensive rewards in the form of high profits and record executive compensation, working class people are increasingly expected to shoulder the costs of supporting the social infrastructure that all Canadians rely on. All of this should be seen as nothing less than the massive transfer of wealth and income from one class to another. So while the proverbial pie has enlarged have the benefits accrued to a small minority trickled-down to the rest of Canadians? And how has the quality of work and labour been effected since the onset of the recession?

\section{Public Austerity: Who Pays?}

Despite significant corporate profits, a good many Canadians have fallen into deeper debt and higher levels of poverty over the period of neoliberalism. For example, between 1984 and 2009 real average household debt has more than doubled from $\$ 46,000$ to $\$ 110,000$ (Hurst, 2011, p.40).

\footnotetext{
${ }^{151}$ An analysis by the Globe and Mail has recently concurred pointing out: "Businesses were widely expected to use the extra money from successive rounds of tax cuts to build factories and offices and buy new machinery and equipment. At one time, they did just that. From 1960 until the early 1990s, corporations invested almost every penny of their after-tax cash flow back into the business. But the tax cuts appear to have reversed decades of tradition. Investment in equipment and machinery has fallen to 5.5 per cent in 2010 as a share of Canada's total economic output from 6.8 per cent in 2005 and 7.7 per cent in 2000." See Howlett, 2012.
} 
As interest rates lowered, household debt rose as many Canadians came to borrow against the perceived rising value of their households as well as to make-up for declining real earnings. As such, increases in total household debt outpaced growth in incomes as the debt-to-income ratio hit 148 percent in 2009 (a 55 percent increase since 1990) (ibid). In a similar vein, while the debt-toasset ratio remained relatively stable from 1970 to 2007 (hovering around 16.7 percent) it had risen sharply to 19.6 percent by 2009 . An increase of 17 percent and the highest it has been in the last thirty-five years. Matching the growth in overall household obligations has been a significant rise in personal debt loads. ${ }^{152}$ An important contributing factor which partly accounts for the increased borrowing is the decline in personal savings rates. In 1982 nearly 20 percent of disposable income was flowing into personal savings, but this fell to 10 percent by 1994 and then hit ground-bottom at barely 2 percent in 2005. Despite productivity growth increasing 1.7 percent annually between 1989 and 2000 average hourly compensation in the private sector rose less than 1 percent yearly (Barager, 2009, p.80). Because working Canadians continued to receive a smaller share of the newly created value, they increasingly had no choice but to turn to credit as a means of making up for real reductions in their wages and salaries.

Unemployed Canadians and those in transition have been especially hard-hit from rising debt loads. For example, on average, laid-off workers from the recessions of the 1980s and 1990s suffered an 18-35 percent decline in wages five years after being laid-off (Bernard and Galarneau, 2010, p.11). ${ }^{153}$ The 2008 recession seems to have intensified these long-term trends, but with

\footnotetext{
152 Between 2001 and 2009, the personal debt load of the average Canadian adult nearly doubled from a little more than $\$ 20,000$ to more than $\$ 40,000$ when adjusted for inflation. And by 2011 Canadians had the unflattering distinction of ranking first among twenty OECD countries in terms of consumers' debt-to-financial assets and seventh in debt-toincome ratio (Livesey, 2012, p.129).

${ }^{153}$ Like workers laid-off between 1993 and 1997, workers who lost employment between 2002 and 2006 found themselves in a much more polarized labour market: more than one-half of total wage losses and gains exceeded 20 percent. Moreover, the data confirms a downward trend in the quality of work as roughly 14 percent of laid-off workers over 1993-97 and 2002-06 found themselves in employment with lower skill levels than the job lost. Similarly, while approximately 16 percent of laid-off workers over the period 1993-97 lost pension coverage, this had risen to 20 percent
} 
important demographic differences. Whereas a larger share of those who lost employment in the 1980s and 1990s were predominantly male and employed in the manufacturing sector, workers laidoff during the period 2008 to 2011 were older, better educated, equally male and female and tended to work in service-oriented professions. While 46 percent of laid-off workers in the 1980 s came from primary industries, this ratio had declined to 43 percent in the 1990s downturn and 38 percent during the 2008-11 recession. Likewise, almost 40 percent of laid-off workers were aged 45 or older, twice the rate observed in the 1980s (Chan et al, 2011, p.14).

On average, workers who were laid-off during the 2008-2011 downturn and found employment within one-year saw their average weekly wages fall from $\$ 734$ to $\$ 703$. In other words, one-quarter of re-employed laid-off workers saw their weekly wages fall by 23 percent or more, while 10 percent experienced losses of more than 50 percent. These findings are consistent with similar results over the period 2006 to 2008 (Chan et al, 2011). Also, the current economic downturn has effected Ontario disproportionately greater than recessions of past. The share of laidoff workers in Ontario rose from 30 percent in the 1980s recession to 36 percent of total job losses over the period 2008 to 2011 (Chan et al, 2011, p.14). Finally, workers who lost union coverage while moving across jobs experienced average hourly wage losses of 16 percent and average weekly losses of 17 percent, while workers who moved from a firm with at least 100 employees to a smaller firm experienced hourly wage and weekly wage losses of 11 percent and 15 percent. Workers who changed both occupations and industry saw average weekly wages fall by 10 percent. In contrast, employees who gained union coverage or moved to firms with 100 or more workers averaged weekly wage gains of between 8-11 percent suggesting an ongoing union wage premium (Chan et al, 2011, p.20).

for workers over 2002-06 resulting in more than 6 in 10 jobs providing no pension plan (Bernard and Galarneau, 2010, p.14-15). 
Since the recession, the quality of work has continued to degrade with most new positions being part-time, temporary or self-employed. This has hit youth (15-24), the elderly (55 and over), women and racialized persons especially hard as long-term unemployment has surged from 15 percent before the downturn to nearly a quarter of jobless people ever since, with disproportionate impacts for women and racialized groups (ibid; Grant 2011a/b; Block and Galabuzi, 2006). These labour market changes have correlated with marked increases in rates of poverty. Food bank usage across Canada is at its highest level since 1997 , with nearly 900,000 people relying on them in 2010. An increase of 9.2 percent (or 73,000 people) over the previous year and 28 percent higher than in 2008 (CBC, 2010, n.p.). Given the significant undermining of Canada's social safety net over the period of neoliberalism, many who have lost their jobs during the recession and exhausted unemployment benefits are turning to food banks as a means of coping - a return to the liberal voluntarism of the late-19th century. ${ }^{154}$ Given ongoing attacks against the provision of public services, public and private sector unions and a marked increase in inequality and poverty, a radical anti-capitalist program that places social justice and equitable access to public services on the agenda is sorely needed.

There Is Always An Alternative: Making the Case for an Expanded Public Sector

David McNally (2011, p.175) has recently argued: "Every mass movement to change the world begins with struggles to reform society. No movement for radical change begins by demanding revolution as such." As such, any movement seeking an alternative to neoliberal capitalism must find ways of integrating both immediate demands and larger systemic goals in mutually-reinforcing ways. Of course, unless concessions are resisted more will follow. But

\footnotetext{
${ }^{154}$ From one "temporary" food bank in 1981 there are now more than 800 food banks and 3,000 food programs across Canada. Food bank usage grew across every province in 2010 , as did child and youth poverty rates which were up over 10 percent. Close to 1 million Canadians experienced food insecurity, while food bank usage remains 26 percent higher than it was before the onset of the recession. Moreover, 11 percent were first time users, 20 percent are living on an old age or disability pension and 38 percent were children and youth under 18 years of age (Food Banks Canada, 2011, p.3).
} 
resistance is not enough: making the case for an expanded public sector must be part and parcel of any coherent strategy for transformative change. Issues related to growing income inequality, deteriorating working conditions and weakening job security need to be placed within the context of capitalism. Despite the reckless excesses of the banking and financial industries - encouraged by libratory state measures and corporate welfare - capital and the state have since the onset of the recession sought to deepen and extend market-dependence. As part of consolidating the power of capital, tax cuts have become the default answer for nearly all of society's social ills.

But as research by Mackenzie and Shillington $(2009$, p.5) has shown, the average Canadian enjoys approximately $\$ 17,000$ annually from public services - roughly equivalent to the average annual earnings of an individual working full-time at minimum wage. ${ }^{155}$ With broad-based tax cuts the reverse is true - most Canadians lose out. For example, in cutting just 1 percent of the Goods and Services Tax, average Canadians received less than $\$ 50$ per household (ibid). The higher up the income ladder one goes however the greater the returns, particularly when spending on expensive luxury goods. Using those tax dollars ( $\$ 5.7$ billion worth in 2011 dollars) to fund, for example, a national childcare program or redirecting them to local governments would have been a far more productive and socially just use of general tax revenue than token reimbursements. Expanding healthcare, public infrastructure, education and pensions has the potential to reduce dependence on markets and on the private sector. That is why a renewed trade union movement - along with community groups and activists - must make the case that there has never been a better time to undertake a massive expansion of public infrastructure and new shared-cost programs. One of the

\footnotetext{
${ }^{155}$ Of course, the extent of usage changes through the life cycle. For example, seniors benefit less directly from public education that they do, say, from healthcare and pensions, although earlier, particularly if they were parents, the opposite was true. Furthermore, the authors of the study demonstrate how the median Canadian household realizes a $\$ 41,000$ yearly benefit from public services, which is equivalent to roughly 63 percent of median disposable income in a 2.6 person household (Mackenzie and Shillington, 2009, p.6). Also, more than two-thirds of Canadians benefit in some direct form from public services, which are equal to nearly 50 percent of households' total earned income. Education, social services and healthcare in particular, account for 64 percent of total public spending, thereby playing a significant redistributive role.
} 
silver linings of the recession has been the fact that governments can borrow money at historicallylow rates making large scale public reinvestments feasible.

Part of the role of finance is to raise and allocate capital to the broader economy. But by engaging in highly speculative and risky behaviours finance capital is increasingly investing less in real productive activities than highly destabilizing and short-term speculative ventures. In an effort to offset such risk-taking and market-dependence, Sanger $(2011$, p.14-23) has suggested four immediate steps that might be taken: (1) implementing a financial activities tax on financial sector profits and executive compensation which would counteract the under-taxation of the sector as a whole; (2) eliminating tax preferences for stock options and capital gains; (3) reversing recent corporate tax cuts; ${ }^{156}(4)$ and working with other countries to implement a financial transactions tax. Combined these measures could contribute between $\$ 10-15$ billion annually to public coffers. Of course, in addition to the financial sector, the capitalist class as a whole continues to benefit from low levels of taxation.

In an effort to compensate for the growing regressively of Canadian tax policy, McQuaig and Brooks (2011, p.222-246) propose four additional courses of action that could be implemented immediately. First, they suggest adding a new taxation rate of 60 percent to incomes above $\$ 500,000$ (about 61,700 tax payers) and a top rate of 70 percent for income above $\$ 2.5$ million (roughly 5,300 tax payers). These measures could generate upwards of $\$ 7.3$ billion in new annual revenues. Second, they advocate for the creation of a passport-like system of checks and balances in order to clampdown on tax evaders. Such a measure could reestablish some fairness and equity as

\footnotetext{
${ }^{156}$ As argued, studies have yet to demonstrate a clear connection between lower taxes and economic growth. The historical record suggests quite the opposite was in fact true. In periods of higher taxation, such as was the case in Canada during the 1960s and 1970s, economic growth was higher and corporations invested a greater portion of their profits into new machinery and equipment. Recent research by Jim Stanford (2011, p.25-26) has estimated that rather than reducing federal corporate tax rates from 18 percent to 15 percent as P.M. Harper did from 2010-12, reallocating the same amount of money to public infrastructure investment would have elicited ten times as much in new investments. In addition to the $\$ 6$ billion in initial public investment directly funded, such spending would also stimulate approximately $\$ 520$ million in new private sector investment as a result of the positive impact of stronger GDP growth on business investment.
} 
upwards of $\$ 80$ billion annually is funneled out of Canada by high-income earning individuals and corporations using foreign tax havens (Tax Justice Network, 2011.).

Third, they advise closing loopholes and removing tax preferences that benefit mostly the wealthy, such as the practice of only having to report 50 percent of capital gains in individual income which allows businesspersons to expense meals, entertainment, travel and leisure as the cost of doing business. ${ }^{157}$ Fourth, they recommend the implementation of an inheritance tax and using the proceeds to introduce a new education trust for every Canadian child. Unlike most advanced capitalist countries, including the U.S., Canada has had no estate tax since 1972. For amounts over $\$ 1.5$ million a lower rate of taxation would apply, rising to a top rate of 70 percent for large fortunes worth more than $\$ 50$ million. These measures would exclude 98 percent of the Canadian population and would discourage the concentration and centralization of wealth and income by encouraging the redistribution of wealth into smaller units, since the amount of tax could be minimized by spreading the benefits more widely. The measures advanced by Sanger, McQuaig and Brooks could enhance stability of financial markets by reducing the volatility associated with excessive risk taking. Moreover, as they emphasize, a fairer income distribution actually increases upward mobility for individuals by dispersing earnings across the labour market. Additional measures that others have stressed include raising the minimum wage in an effort to boost consumption and enhance income security, as well as implementing a universal basic salary without means testing or work requirements (Brennan, 2012; ; Van Parjis and Vanderborght, 2012).

While enhanced "regulations" on capital are important and necessary for any radical strategy aiming for a more equitable and just society, absent the fundamental reorientation of the financial sector as a whole these initiatives will remain incompatible with the logic of capital and therefore

\footnotetext{
${ }^{157}$ Ultimately, there are few convincing arguments which demonstrate why income earned from capital gains or stock options should be taxed at a lower rate than other forms of income such as salaries and hourly wages. In fact, a 1966 Royal Commission on Taxation agreed, recommending that all income be treated equally for the purposes of taxation (McQuaig and Brooks, 2011, p.228).
} 
temporary and conjunctural at best. Rather than continuing to rely on the private sector as the engine of economic growth and investment, an alternative framework must come to advance a vision of democratic social planning within an expanded public sector. This includes efforts intent on not only gaining state power but radically transforming it as part of broader efforts to transform social and economic structures (Albo et al, 1993; Panitch, 2008). As Marx (1875, n.p.) once put it, freedom consists in converting the state from being an organ of despotism superimposed upon society to one completely subordinate to it. The current neoliberal paradigm will not offer any real solutions so long as capital continues to set the terms and conditions upon which production and investment are allocated. Any discussion about expanding the realm of public services, then, must inevitably come to terms with the need to democratize finance by turning it into a public good. Without undercutting the structural power of capital, plans to expand public services will always be at the mercy of the financial sector and capitalist class. Thus pressures must include aims to not only "re-regulate" but to socialize, that is, nationalize the sector as a whole - the opposite response to privatization.

Often, calls for "re-regulation" implicitly assume that the state and market stand in opposition to each other. But as the state interventions and practices discussed in chapters four through six make clear, state policies have reinforced market mechanisms and increased precarity rather than challenged the rule of capital in any way. Furthermore, part of the problem with calls for state "controls" and "regulations" on capital is that they fail to identify the problem as systemic and structural - that is to say, endemic to capitalism and the ways in which capital and the state have extended and reproduced neoliberalism. Rather, what is fundamentally needed is to transform the whole banking sector into a public utility so that the distribution of credit and capital could be undertaken with democratically established principles. Because the public remains the lender of last resort and all persons require or deposit some form of their earnings in banks, there are few if any 
convincing reasons for private ownership of the banking sector. Moreover, the governmentmandated central bank preserves the quality of national money and enables competing banking institution to regulate their dealings with one another. In addition to tightening financial regulations, nationalizing parts of the banking sector could remove the institutional and financial infrastructure of capital, thereby enhancing democratic control and potentially serving as an example for other sectors of the economy. Of course, in order to accomplish this it is necessary to change the social attitudes about the role of finance and taxation and make the connections between social justice and democracy. Starting with making the rich pay is an important first step, but increases to corporate and income taxes do not go far enough. Focusing only on the rich reinforces a perverse kind of individualism that reinforces populist anti-tax sentiments. Making the case for an expanded public sector through massive investments in healthcare, education and public infrastructure have the potential to reduce the dependence on private capital and markets, and shifts the focus from deepening market incentives to extending collective capacities for the public good. In other words, by turning the banks into a public utility they could become instruments of popular control and democratic social planning, which creates the possibility of democratizing the productive base of the economy as a whole. Only in the course of pushing for both enhanced regulations and transformation of the financial sector might the seemingly impossible become politically plausible. Marx and Engels repeatedly stressed that the equalization of classes was fundamentally incompatible with the capitalist system, so while greater 'balance' is important a renewed working class politics must seek to transcend class privileges.

With the onset of the 2008 recession renewed hopes about the viability of a social democratic resurgence gained widespread political momentum (Bello, 2008; Fernandez, 2009; Desai, 2009). Such optimism, however, proved both short-lived and politically misleading. Through the crisis social democracy has moved further away from labour and increasingly toward centrist, 
even reactionary, positions (Evans, 2012). Equally important, it is necessary to recall that the demise of the Keynesian welfare state occurred not so much for a lack of creativity in policy making, but rather because of its fundamental inability to sustain capital accumulation in light of rising working class standards of living. This is a contradiction Keynesianism and social democracy are powerless to overcome. The working class struggles and mobilizations that launched the Keynesian welfare state emerged from an earlier period of capitalist crisis backed by militant trade unions and socialist-inspired political formations. However, social democracy today, particularly in its New Democratic form, has rid itself of whatever radicalism it may have had in the past having made peace with capitalism (Carroll and Rater, 2005; Evans and Schmidt, 2012 ).

In this regard, while Keynesianism and social democracy are theoretically subtler or 'softer' forms of neoliberalism, they are no longer real progressive political alternatives. Neoliberalism has eroded whatever 'progressive' remnants of social democracy that remain. In fact, social democracy has increasingly shown signs of intellectual confusion having failed to break ideologically or politically with a social dependence on capital, let alone meaningfully intervene in recent labour struggles. In other words, the NDP has no transformative vision of society, adheres to the economic agenda of neoliberalism and displays no interest in challenging the logic of capital or the democratic functions of the state. The tenures of Premier Rae in Ontario and Mayor Miller in Toronto lead precisely to these conclusions as each sought to deal with the structural constraints imposed by neoliberal policies (and capitalism more broadly) by further entrenching market reforms. Moreover, the NDP, like the Liberals and Conservatives, remain trapped in top-down organizational structures with little interest in building mobilizational capacities with labour or at the community and grassroots level (Evans, 2012; Pilon et al, 2011).

Dedicated organizing strategies intent on creating new inroads into spaces currently seen as private must emphasize the social value of extending public services. Making the case for an 
expanded public sector via the democratization and socialization of the financial sector fundamentally opposes the prevailing orthodoxy of neoliberalism - one that challenges private capital accumulation as the engine of economic growth - and raises a set of demands for noncommodified labour and services. This means not only expanding the redistributive role of the state but actually taking the lead in ensuring that access to housing, public transit, pensions, healthcare, as well as improved working conditions, immigrant and environmental rights are available for all Canadians. "In not adequately reinvesting its profits in decent jobs, the private sector is openly admitting that it cannot provide decent jobs for everyone" (Gindin, 2012, n.p.).

The dead end of neoliberalism and austerity will only make things worse. Reducing public spending will increase unemployment, weakening consumption and chocking-off any economic growth. Rather, widely socializing the means of production with large investments in the public sector will boost overall employment, fueling domestic demand, and improving the living conditions of Canadians through a more equitable, participatory and democratic form of governance and social planning. The fact that capital has so much money that it does not know what to do with it, while middle- and low-income earners fall deeper into debt and poverty, implies that a new historical project must be placed on the agenda.

It is necessary to recall that "Historically, collective political action has been organized labor's favored and most successful vehicle for progressive change. (Savage, 2009, p.17). While the courts have played an important role in protecting basic rights to freedom of association, extending some gains to the unorganized and establishing workplace minimums, its progressivity has always been the result of sustained politicization and class struggles. "[N]o constitutional document, however progressive, can replace the need for sustained political struggle to protect and enhance workers' rights...[A] liberal rights-based strategy may yield positive results in the short term, over the long term, it may turn out to be the quickest path to irrelevancy for a labor movement that 
continues to tread water in an era of neoliberal globalization." (Savage, 2009, p.18). Relying on the courts and the legal system to protect and enhance workers' rights and freedoms is a non-starter. The trade union movement cannot rely on lawyers to make arguments and then hope the confines of labour law allow for judges to rule in their favour (Walchuk, 2011). Given the anti-workers' architecture of the law, only a class-oriented trade union movement espousing a working class politics that seeks to transcend the capitalist system may offer a way out of the crisis that is capitalism.

\section{Conclusion}

The shape taken by struggles over austerity and social services may determine whether neoliberalism continues uninterrupted or alternatively whether something new and historically unique can capture the public's imagination. Given the scale and scope of what labour unions and the working class's are collectively up against, organizing solely around specific issues and particular constituencies - as impressive and energetic it may be - cannot add up to the kind of strength, organization and structure that is needed to bring about all-encompassing change. To that end, labour unions remain the largest, most organized, resourced and stable institutions institutions of a class "in itself" but not yet "for itself" - fighting against the rule of capital. But as Marx and Engels stressed, while trade unions must be a central part of this progressive political renewal, their renewal is equally dependent upon a broader revitalization of working class politics. The course of neoliberalism has thoroughly beaten back what vestiges remain of trade union militancy, notwithstanding important exceptions, while social movements generally remain isolated in small-scale and resource-poor coalitions. Given the ongoing onslaught against public services, private and public sector unions as well as declining standards of living, unions and the broadly defined Left must come to the bitter realization that the existing ways of doing things are not working. This is the only realistic starting point from which to move forward. 
New coalitions, alignments and networks will most certainly emerge as the austerity agenda hardens. The failure of both organized labour and social justice communities to confront what the working class is collectively up against belies the need for a new kind of radical, anti-capitalist political project suited to the current social conjuncture. The GTWA is a unique and creative political formation trying to broaden the anti-capitalist base. Additional political experiments will need to emerge that aim to incorporate the strongest elements of the traditional party, trade unions, social movements and community groups. Accepting the existing social relations as unalterable would be to recognize the right of capital to exploit labour. As Peter Mieksins (1986, p.118) once put it: "To abandon class politics and the effort to unify the working-class becomes a sure way of maintaining the capitalist mode of production".

Increasingly, the fate of Canadian labour as a social and political force rests on the shoulders of the public sector trade unionists which form the bulwark of Canadian labour. Nonetheless, private sector unions will continue to play a significant role in challenging capitalist control over the means of production, as will the unemployed and non-unionized. Income and wealth polarization are on par with levels unseen since the 1930s, although there has yet to be a commensurate rejuvenation of socialist and anti-capitalist inspired mobilizations. Despite significant corporate profit-rates or, perhaps, precisely because, the future of public services and trade unions are as insecure and fragile as ever. The challenge facing trade union and social justice activists is to move to the anti-capitalist left or risk increasingly becoming an impediment to rather than an instrument of a renewed working class politics. The failure to do so may regrettably amount to an historic class defeat. 


\section{Conclusion}

Trade union rights and freedoms, the public provision of social services and working class standards of living more generally are currently under attack and will likely remain so indefinitely. While austerity has been the buzzword of the last five-odd years, when considered in historical perspective it is plain to see that Canadians have been living with varying degrees of austerity for at least the last three decades. In this sense, public services and collective bargaining rights have been gradually eroded over an increasingly indeterminate era of austerity. The severity of the Great Recession has given renewed vigour to intensify long-term efforts to undermine the public provision of social services and reduce workers' ability to chart a path independent from the vagaries of capital. Indeed, unions generally and public sector unions in particular seem ever more incompatible with the profit-driven goals of capitalist development. Since the 1980 s, there has been a slow but steady downward convergence in working conditions and wages, backed by employer and state efforts to lower unions' and working class expectations.

As the immediacy of the economic crisis recedes from public scrutiny in Canada, however, its aftershocks continue to strain public finances and social services with grave implications for all Canadians. It is worth recalling that the public treasury bailed-out the banks and corporations by taking on their bad debts, supplying new subsidies, lowering corporate taxes and increasing state spending in order to counter a sharp recession. As a result, a private sector-generated economic crisis moved into the public sector. Paradoxically, despite being the source of the costs of the crisis that now burdens the public sector, the capitalist class continues to demand government austerity. In place of bloated CEO salaries and the reckless excesses of the financial sector, media and political attention is fixated on cutting public services and attacking public employees, the poor, pensioners and just about any user or producer of public services. Thus the redefinition of the crisis as 
stemming from a bloated and inefficient public sector and unionized workers' living wages is a less than genuine depiction of actual affairs.

Through the crisis, capital has displayed a stubborn unwillingness to give up any of its class privileges, thus blocking the possibility of both stricter regulations and more radical, transformative policies. This raises the issue of needing to address directly the class relations and forms of state power that continue to forcibly remake and restructure the institutional and social conditions so as to accelerate capital accumulation. Historically, socialist-inspired and social-democratic political parties and trade unions have been the primary instruments of working class organization. In many cases, the goal was to procure state power in order to either regulate or supplant capitalist class domination. Thus there was an explicit recognition of the class relations which underpin the system as a whole, and the class struggles which made control over the state and against capital an ongoing field of confrontation.

In present form, unions in general and public sector unions in particular are often unwilling and, more importantly, unable to counter the consolidated power of capital and the state. This raises concerns over the economic and political limitations as well as structural constraints, which frustrates trade unionism as an end in itself. Likewise, with socialist perspectives pushed to the margins of political discourse and social-democratic parties' retreat from class politics, it is unlikely that an alternative, anti-capitalist program might gain political traction without a broader working class politics with feet both inside and outside the official trade union movement. This is the challenge before labour and social justice activists today: to ensure that the defeat of labour in the twentieth century does not turn into the defeat of the working class in the twenty-first century. 


\section{Summary}

In Chapter one, I provided a brief historical overview of the important socio-economic and political transformations from the 1850 s to 1940 s. Over this time, the material relations of production which had once been sheltered from market forces were gradually eroded removing traditional rights and security over the means of subsistence. As ownership and control over the means of production were centralized - backed by state sanctioned monopolies and legislative acts - workers increasingly sought to resist the dangerous, low-paying and laborious rhythms of capitalist forces by attempting to organize themselves into unions. While industrial unions continued to struggle over trade union recognition, public sector workers' associations distanced themselves from the labour movement and working class politics more generally, preferring to associate themselves with and rely on the goodwill of management and cabinet. Through the First World War, Great Depression and Second World War, however, class struggles accelerated.

Struggles at the G.M. plant in Oshawa and elsewhere had established industrial unionism as a promising form of working class organization. Public sector associations however remained by and large conservative, appealing occasionally for greater input over decision making but rarely backing their discontent up with genuine signs of militancy. While there were obvious exceptions, eruptions of public sector workplace militancy were few and far between as most associations were organized in a limitedly legal as opposed to political form. By the mid-1940s, private sector unions had fought for and won the right to organize and bargain collectively as is evidenced with the breakthrough legislation of PC 1003 and the Rand formula. Most public sector associations and unions, though, remained limited to occasional consultations lacking the active solidarity and legal machinery recognizing and extending the right to strike and bargain collectively. As a result of the growing politicization of industrial unions and mounting appeal of socialist politics, it was also in 
this period when the state began reluctantly taking greater responsibility for social welfare provisioning and seeking to 'mediate' a consensus between capital and labour.

As I argued in chapter two, however, these measures were never ends in themselves but means through which subordinate classes could be integrated all the while advancing capital accumulation. While the theoretical ideas advocated by Keynes promoted the expansion of broad social services and active fiscal and monetary policies, the general thrust of Keynes' work was concerned with stabilizing the capitalist system rather than altering it in any fundamental ways. This had significant implications as the welfare state incorporated broad bands of trade unions into the vast architecture of labour law, while at the same time constraining militancy and their scope for agency with wide-raining social enticements as a patch onto the flawed fabric of capital.

Nevertheless, through this period the balance of class forces shifted as labour unions and other progressive movements began agitating for improved pay and working conditions, and the extension of social security rights. General welfare initiatives such as unemployment insurance, family allowances and old-age pensions entrenched a sense of collective social responsibility as the public came to expect more from their governments and employers. With the extension of collective bargaining rights through the $1950 \mathrm{~s}$ and $1960 \mathrm{~s}$, the terrain of legitimate trade unionism was simultaneously constrained and expanded: although unions were formally recognized as lawful actors bargaining on behalf of their memberships, those same laws and regulations worked to entrench a system of highly specialized and legal negotiations. As a consequence, the militant anticapitalist political mobilizations which had characterized the inter-war years fell to the wayside as legal negotiations and restrictions confined trade unionism to the collective agreement.

Despite these tensions, public sector unions increasingly came to espouse a politicized trade unionism casting off their previous hostility to working class politics, although demands sought not so much to transcend the capitalist system but to expand benefits within it. However, just as public 
sector workers were beginning to assert their right to strike and bargain collectively, wage and price controls through the 1970s and 1980s essentially nullified any genuine notions of free collective bargaining. I argued that the growing use of back-to-work legislation and injunctions, including the fight against inflation over full-employment, suggested that the state was far from an 'impartial' umpire but a coercive player in aiding the capitalist class in taming or subjugating workers when market mechanisms for doing so fell short. As the composition of the public sector shifted through this time, in addition to demands for improved pay and working conditions once subordinate issues such as sexual harassment, maternity leave, child and elder care, and sex-segregated employment were brought to the forefront of negotiations. Thus the growing militancy of public sector unions backed by the radicalizing influences of younger, female workers increasingly jettisoned their conservative past.

Over the decade both the Trudeau and Davis governments responded with harsh austerity measures restricting the parameters of free collective bargaining and, when necessary, removing them altogether. Similarly, private employers also responded with intensified efforts to resist unionization and curb wage militancy. As the foundation of the Keynesian compromise was slowly chipped away at, neoliberal policy prescriptions espousing the virtues of the free market increasingly gained widespread reception in policy making circles, business and the general public. With the abandonment of full employment policies in favour of inflation-targeting, I argued that Keynesian welfare state was dealt its death-knell.

In Chapter three, I examined precisely how this happened and the consequences this has had on public services and public sector unions. I contended that Keynesianism was an historically unique response to then-contemporary circumstances at a point when the very legitimacy of capitalism was uncertain. In a similar vein, neoliberalism emerged as a political response and class project in the midst of a crisis of accumulation for the purposes of restructuring relations between 
labour, capital and the state. Thus, in overviewing the shift from Keynesianism to neoliberalism, I drew attention to the ongoing evolution of capitalism in its various phases and forms. Through this period, to varying degrees, each of the governing parties sought to thoroughly embed market compulsions into the overall architecture of the public sector. From contracting-out and privatization measures to the increasing use of part-time and limited-term appointments, insecurity of job tenure become the new norm as the standard employment relationship was replaced by increasing forms of precarious work. Likewise, in an effort to make the public sector more like the private sector - that is, less secure and more exploitative, public sector unions were increasingly targeted as scapegoats of so-called reform. Under the guise of economic crisis, public sector unions and social services were identified as prime targets of austerity as "essential" designations, wage freezes, layoffs and expenditure cuts expanded the terrain of capital accumulation. This was most clearly evident in the 1995 federal Liberal and Ontario Conservative budgets, which emblematically marked the point where erosion of social services ended and demolition began. Erosion and retrenchment over this period, however, had not been one-directional but cumulative with fluctuations of varying intensities.

From striking PSAC and CUPW workers to OPSEU and the Ontario teachers unions' strikes through the 1990s, public sector unions continued to challenge unilateral managerial prerogatives and attacks against living wages, working conditions and benefits. Often extralegal, many of these strikes demonstrated the importance of political unionism for public sector unions exploding any remnants of their historical diffidence. Despite the important struggles in defense of their members and broader public services, however, the cumulative effects were to lower the expectations of workers while victories were reduced to limiting the extent of concessions. I argued that this is a structural limitation which unionism alone is unable to overcome. The state-as-employer not only legislated away collective bargaining rights and freedoms, but actually reinforced tendencies toward 
individuation through encouraging individual overtime, supporting debt and mortgages, reshaping labour law and so forth. In trying to survive in the absence of collective capacities, trade unionists and working class people had few options but to embrace such individualized 'solutions' and so reproduced neoliberalism. Thus I argued that the broad history of the period 1984 to 2005 can be characterized as the gradual, albeit uneven defeat of labour in the face of ongoing state and employer militancy.

In chapter four, I contended that the Harper Conservatives have used the Great Recession as a political justification to institute privatization measures, increase layoffs, reduce access to services and circumvent the collective bargaining process. This was demonstrated through enhanced forms of corporate welfare, increased outsourcing, real reductions to public spending and the implicit and explicit stifling of free collective bargaining. As the case of PSAC Local 70396 shows, using the excuse that the recession demanded austerity, the CMCC - a federal Crown corporation - tried to increase the use of contract work, weaken job security provisions, reduce compensation and benefits, and implement privatization measures. PSAC's ability to resist some of these concessionary demands are important and noteworthy, however the overall success of the strike was far from a real breakthrough as cumulative gains were few. Nevertheless, PSAC Local 70396 members demonstrated that fighting back matters. But the turn to coercion and state authoritarianism became all the more apparent with the Harper Conservatives' gaining of a majority government and their subsequent use of back-to-work legislation. As the cases of striking CUPW and CAW workers suggests, public and private sector unions remain unable to transcend the structural limitations of unionism as well as the cycle of austerity and retrenchment amidst periodic crises of accumulation.

In chapter five, I extended this analysis to the Ontario Liberal government. I made the case that rather than depart from the Common Sense Revolution of the Mike Harris Conservatives, the 
McGuinty Liberals incrementally continued along the path of neoliberalization. Although the first mandate of the Liberal government was characterized by relative labour peace, this was not because of a new consensual process of negotiations with organized labour but due to the historically specific economic and political circumstances of the time. This era of relative public sector labour peace also signified the adaptation and limited political horizons of labour as they sought to conform to neoliberalism rather than challenge the lack of substantive alternatives. I argued that since the onset of the Great Recession the Ontario Liberals increasingly adopted a more authoritarian form using the economic crisis as a justification for austerity.

In addition to a wage freeze for public sector workers and less than genuine negotiations with public sector unions, including generous forms of corporate tax relief, trade liberalization and regressive reforms to employment standards legislation, the Liberals implicitly circumvented the collective bargaining process by tying fiscal policy to demands for workers' concessions. These implicit constraints were evident in the 2010 round of collective bargaining between Carleton University and CUPE Local 4600 . Because the Liberals maintained that they would not be funding any net compensation increases related to collective bargaining, the Carleton administration used this as a political pretext to attack its most vulnerable and precarious workers. This included demands for a wage freeze, increased surveillance mechanisms, harsher disciplinary measures, attempts to expand the administration's ability to unilaterally make job appointments, and the university's unwillingness to place a cap on TA-to-student ratios or to extend healthcare benefits to contract instructors.

While there was no major confrontation in the form of a strike or major concessions, new spaces were opened so as to create more opportunities for surveillance and disciplinary measures. While CUPE 4600 was successful in generating some minor wage increases, coupled with minor improvements in emergency funding and professional development, rising tuition costs and 
inflation will likely nullify any real benefits. The threat of increasing precarization looms large as the university continues to move away from more secure, tenure track positions in the form of the standard employment relationship and toward part-time and contractual employment. The case study of CUPE 4600 revealed important insights for other unions, particularly in the PSE sector, to draw upon in the continued struggles against concessions. But as I argued, few if any forms of unionism alone are capable of resisting state austerity and the capitalist class' aggressive push for commodification in the absence of an oppositional political and organizational form in which to anchor their politics. Despite sporadic and uneven resistance to demands for concessions from workers, pressures to reduce services and increase private sector penetration are intensifying through the crisis.

As I argued in chapter six, the severity of the Great Recession led to new rounds of attacks against municipal services and workers. I made the case that through the 2009 round of bargaining between the City of Toronto and its civic workers, the City sought to shift the burden of recession onto workers by positing a false trade-off between wage restraint and the protection of public services. Given the location of Toronto as the strategic centre of financial capital in Canada and home to Canada's largest municipal union, Local 79, the 2009 round of bargaining served as a political experiment of sorts as capital sought to commodify new spaces for accumulation. Rather than retreat from the neoliberal project or present an alternative developmental path in the face of declining revenues, the 'Third Way progressivism' of the Miller regime sought to extract concessions from workers using the recession and declining revenues as a legitimating rationale.

While the 2009 civic workers' strike managed to achieve some minor increases in economic compensation, it was a significant political failure in its inability to draw connections between the attacks against public services and workers to tax shifting for competitiveness and chronic underfunding of cities. Few connections were made between the defense of public sector workers 
and the services they provide and their relationship to the users of those services or how the underfunding of city services has been decades in the making. These concerns could have been framed as a clear political message arguing in favour of decent working conditions for all. Unfortunately, as I argued, Canada's largest municipal Local demonstrated an alarmingly illequipped response to the City's demands for concessions. These failures formed part of the backdrop leading to the election of an arch-conservative mayor and council, which ran on a platform explicitly announcing their intention to strip the city's unions of their hard won gains, privatize services and assets, and increase worker discipline.

In the face of such attacks, I made the case that if unions are to reappear as a movement and not simply hang on as a relic of the past, they need to move beyond the limited defense of their own members' interests and to those of the working class as a whole. In my view, doing so requires having feet both inside and outside the trade union movement - that is to say, rooted in an organizational form explicitly intent on building a broader working class movement across the many cleavages among workers and grounded in a critical analysis of (neoliberal) capitalism. In light of historical and contemporary attacks against free collective bargaining, it is becoming increasingly clear that unions and oppressed persons generally can no longer, if they ever could, put their faith in the courts, laws or governments to enforce the postwar class compromise. This postwar consensus has been thoroughly eroded in the face of trade union and activists' inability to adequately counteract cumulative decades of concerted attacks.

It is for these reasons that in chapter seven I explored what Marx and Engels identified as the progressive potential and political limitations of trade union organizing as an end in itself. Although trade unions emerged from the working class, they did not come to represent the interests of the class as a whole. Thus, while organizing workers at the point of production is not only 
important but necessary, I argued that in failing to come to terms with the root sectionalism of trade unionism organized labour risked impeding the formation of an alternative class project.

Increasingly, the fate of Canadian labour as a social and political force rests on the shoulders of the public sector trade unionists which form the bulwark of Canadian labour. Nonetheless, private sector unions will continue to play a significant role in challenging capitalist control over the means of production, as will the unemployed and non-unionized. Despite more than a quartercentury of neoliberalism and the intensified attacks in light of the Great Recession, there has yet to be a commensurate rejuvenation of socialist and anti-capitalist inspired mobilizations.

Examining the reasons for these failings is important since the shape taken (or not taken) by struggles over austerity and social services may determine whether neoliberalism continues uninterrupted or whether something new and historically unique can capture the public's imagination. Considering what the working class is collectively up against, I argued that organizing solely around specific issues, workplaces and particular constituencies cannot add up to the kind of strength, organization and structure that is needed to bring about all-encompassing change. Although labour unions remain the largest, most organized, resourced and stable institutions fighting against the rule of capital, they cannot themselves beat back the consolidated attacks by the state and capital. While trade unions must be a central part of any anti-capitalist renewal, their renewal is equally dependent upon a broader revitalization of working class politics. The course of neoliberalism has thoroughly beaten back what vestiges remain of trade union militancy, while social movements generally remain isolated in small-scale and resource-poor coalitions. Given the ongoing onslaught against public services, private and public sector unions as well as declining standards of living, trade unionists and social justice activists must come to the bitter realization that the existing ways of doing things are not working. This, in my view, is the only realistic starting point from which to move forward. 
As such, I argued that as a result of both organized labour and activists' inability to confront what the working classes are collectively up against belies the need for a new kind of radical, anticapitalist political project suited to the current historical and social conjuncture. The challenge before trade union and social justice activists is to move to the anti-capitalist left or risk increasingly becoming an impediment to rather than an instrument of a renewed working class politics. The failure to do so may regrettably amount to an historic class defeat. Despite the setbacks to trade unionists and social justice activists over the period of neoliberalism, it is necessary to learn victory from defeats. Revitalizing the theoretical and political promise of a renewed working class politics remains a crucial step in resisting austerity and potentially realizing a better world without capitalism.

\section{Limitations and Future Research}

Dissertations rarely present definitive conclusions, but are rather selective intellectual interventions in particular theoretical, empirical or social policy arenas. From the terrains of exploration and set of questions asked to the theoretical and methodological approaches, despite the voluminous amount of text in this study, the conclusions reached are but a snapshot in the ongoing evolution of neoliberalism, austerity and workers' resistance to capitalism. As such, in drawing attention to the shortcomings and limitations of this study, I aim to bring to light present weaknesses so that they may be engaged with and remedied in future research. In exploring some 150 years of social policy development and trade union struggles, depth at times has certainly been substituted for breadth. In trying to give a 'big picture' perspective, important historical nuances and distinctions have no doubt been missed. In making such a decision, I prioritized situating contemporary events with an eye to long term processes in the broad history of capitalism. Any decision to focus on one period or another is inevitably fraught with problems. In composing this study, I ultimately believed that there was more to be gained than lost in tracing the evolution of 
capitalism, public policy and public sector unions and the specific ways these historical forms have intersected with contemporary public policy debates and the particular case studies under review. In the end, the extent to which I was able to competently integrate an historical and contemporary analysis is a question that must be answered by others.

Additionally, in utilizing a participant observer methodological approach I devoted little to archival research and few formal interviews. In the case of the former, there is often limited existing material beyond meeting minutes, speeches, official statements and journalistic articles although this remains an important area for future research. In the case of the latter, I prioritized engaging trade union members in informal conversations as I was concerned that formal knowledge of my research may alter behaviour, attitudes and interactions. While some were aware and did participate in formal interviews, a larger range of formal responses may have perhaps led to new insights. Another methodological concern is related to the fact that it may be difficult to check or repeat the study for reliability given the particular round of collective bargaining and actors involved, the period of the recession and the uniqueness of the strike. An analysis of other strikes could potentially reveal to what extent the strikes under analysis in this study are representative of larger ongoing trends.

There are undoubtedly central theoretical assumptions and explicit claims that others will take issue with. A short catalogue includes: my particular critique of Keynes; the claim that the welfare state actually embedded rather than sheltered certain public services from commodification; the extent to which the Canadian state was and remains a pathbreaker in implementing neoliberal reforms; my claim that the Great Recession served as a political pretext for attacking public services and workers; and, perhaps most contentiously, my own interpretation of the three case studies and how they might differ from the views of others directly or indirectly involved in the strike. These are all subjective claims, which I have tried to theoretically and empirically substantiate throughout. 
Nevertheless, all claims are a matter of perspective and new insights will unquestionably be revealed as my own analysis intersects with those of others.

While I have endeavoured to thoroughly unpack the distinctive ways in which class, gender and racial oppressions have interacted, in focusing on the broader structural/institutional and macroeconomic and political processes at work the specifically gendered and ethno-racial consequences of collective bargaining in an era of austerity have been given less attention than they deserve. Future research will need to correct these oversights and failures in order to make clear how the consequences of austerity are differentially experienced based on identificational characteristics. Related, in focusing attention on what I perceive to be the shortcomings and limitations of trade unionism as an end in itself, scant attention has been devoted to exploring the role that community and social justice activists' have played in challenging, on the one hand, unions to become centres of working class activity and, on the other, mounting challenges to state policies and corporate practices. This is an important area of study that ongoing and future research should devote ample consideration.

Equally important, I have devoted modest attention to both the modes of unionism debates and also the role that international forms of organization or international labour bodies have played as avenues of workplace organization. In the case of the former, debates about "business", "social", "mobilization" and "social movement" unionism, for example, are important and worthy of much discussion. Since others have been and continue to engage in such debates, in the absence of an indepth original contribution I made the choice to identify what I saw as common analytical shortcomings and use that as a reference point to stress the need to transcend unionism as an independent form of viable political radicalism. Instead, I argued that debates about union renewal without an explicit recognition of the root sectionalism of trade unions will inevitably fall short of what is actually needed: to have feet both inside and outside the trade union movement with the 
explicit aim being to renew working class politics as a whole and cultivate an alternative, anticapitalist political and economic program. In other words, to shift the emphasis away from trade unionism and toward class unionism as a site for anti-capitalist renewal. Of course, the two spheres are intimately connected but only in recognizing these connections might the debate move from how to renew unions in their limited form to how the working class can use unions as specific "points of attack" or "agencies of organization" as Marx and Engels put it earlier.

In the case of international solidarity and international labour bodies, my reasoning for ignoring or paying little attention to them is more a matter of practicality, which is not to say unimportance. Marx and Engels recognized long ago that while capitalism is international in substance, it is reproduced in national form. Thus although they were passionate internationalists, they understood that internationalism began at home and that the "proletarian must first of all settle matters with their own bourgeoisie." (Marx and Engels, 2002, p.232). While international solidarity campaigns are important and can certainly go a long way in mobilizing demonstrations of collective support, information and analysis, absent a domestic anchor in which to orient struggles its limitations must be made clear. The inter-state system remains the central institutional framework stabilizing global capitalism. The "extra-economic" supports provided by the nation-state in the form of consistent and reliable enforcement in contractual relations, monetary standards, exchanges of property, a stable and predictable social order and general infrastructure makes the nation-state indispensable to the day-to-day functioning of capitalism. As a result, capital and the state remain subject to mobilized internal oppositional forces and pressures related to discontent, while the root of democracy lies in local and national movements fighting in defense of their workplaces and communities. As Sam Gindin has put it, "building a strong, solidaristic organization domestically is the condition for any meaningful internationalism." (Gindin, 2004, p.7). This is not to say that bringing international attention to Canada's abysmal record of respecting trade unions' right to 
organize and bargain collectively is unimportant nor that international solidarity campaigns are insignificant, but to stress the need to build a strong foundation locally, regionally and domestically with the hope that solidarity can go beyond sloganeering. This is a position which others will certainly disagree with, but the justifications to the contrary have yet been convincing. On a related note, I have also paid little attention to the role that municipal, provincial and national labour federations have played in challenging neoliberalism and austerity. The lack of engagement with labour federations, while outside the purview of this study, is an important area of research which could shed light on additional challenges and potential openings for the trade union movement.

Finally, while my study has focused on three different political parties (or governing coalitions) at three scales of governance, as well as three distinct union Locals of varying sizes, histories and diverse forms of public sector work, other studies will need to explore if similar events have transpired in different municipalities, provinces and even countries. The specific forms neoliberalism has taken, the distinctive responses by governments and the particular ways that capital have responded to the Great Recession will vary, as will the responses by trade unions in the public and private sectors as well as community groups and social justice activists. This specificity must be analyzed in conjunction with the broader claims made throughout this work to test its validity and generalizability. To conclude, public services and the extent to which public sector unions can resist state and capitalist class militancy appears increasingly fragile and insecure. A renewed labour movement must begin with the recognition that capitalism is a criminal system incompatible the interests of the overwhelming majority of the earth's inhabitants. As the austerity knife gets sharper and cuts deeper, and class polarization reaches new heights, a twenty-first century trade unionism must come to terms with an increasingly authoritarian state and aggressive capitalist class as the limits of trade unionism are exhausted. This is the essential precondition for any 
revitalization of working class politics and a crucial step in resisting austerity and demanding substantive alternatives. 


\section{Reference List}

Abella, I.M. (1973). Nationalism, Communism and Canadian Labour: The CIO, the Communist Part, and the Canadian Congress of Labour, 1935-1956. Toronto: University of

Abelson, D.E. and C.M. Carberry. (1998). Following Suit or Falling Behind? A Comparative Analysis of Think-Tanks in Canada and the United States. Canadian Journal of Political Science, 31(3), 525-556.

Abu-Laban, Y. and C. Gabriel. (2002). Selling Diversity: Immigration, Multiculturalism, Employment Equity and Globalization. Peterborough, Ontario: Broadview Press.

Adelaide, D. (2003, April 23). Air Canada Using Bankruptsy Proceedings to Gut Jobs and Wages. World Socialist Web Site. http://www.wsws.org/en/articles/2003/04/airc-a23.html Aglietta, M. (2001). A Theory of Capitalist Regulation: The US Experience. New York: Verso. Akyeampong, E.B. (2004). The Union Movement in Transition. Perspectives on Labour and Income, 5(8), http://www.statcan.gc.ca/pub/75-001-x/10804/7011-eng.htm

Albert, R. (2002). Why Business Wants Privatized Education. British Columbia Teachers Federation. Retrieved February 22, 2011 from, http://bctf.ca/publications/NewsmagArticle.aspx?id=11192\&printPage=true

Albo, G. (1993). The Public Sector Impasse \& the Administrative Question. Studies In Political Economy, 42, 113-127.

----- (1994). 'Competitive Austerity' \& the Impasse of Capitalist Employment Policy. Socialist Register, 30, 144-170.

----- (2009). Challenges for Urban Social Justice Movements, Neoliberal Urbanism, the Canadian City and Toronto. Toronto: Centre for Social Justice. 
--- (2010). The 'New' Economy and Capitalism Today. In N. Pupo and M. Thomas (Eds.), Interrogating the New Economy: Restructuring Work in the 21st Century (pp.3-20). Toronto: University of Toronto Press.

Albo, G. D. Langille and L. Panitch (Eds.). (1993). A Different Kind of State? Popular Power and Democratic Administration. Toronto: Oxford University Press.

Algo, G. and D. Crow. (2008). Under Pressure: The Impasses of the North American Labor Movements. In Abu-Laban, Y., R. Jhappan and F. Rocher (eds.), Politics in North America: Redefining Continental Relations (pp.273-294). Peterborough: Broadview.

Albo, G. and H. Rosenfeld. (2009). Toronto City Workers On Strike: Battling Neoliberal Urbanism. The Bullet, http://www.socialistproject.ca/bullet/bullet232.html

Albo, G. S. Gindin and L. Panitch (2010). In \& Out of Crisis: The Global Financial Meltdown and Left Alternatives. Oakland: PM Press.

Anderson, K.B. (2010). Marx at the Margins: On Nationalism, Ethnicity and Non-Western Societies. Chicago: University of Chicago Press.

Arat-Koc, S. (1997). From Mothers of the Nation to Migrant Workers. In A. Bakan and D. Stasilus (Eds.), Not One of the Family: Foreign Domestic Workers in Canada. Toronto: University of Toronto Press.

Armstrong, P. and H. Armstrong. (1994). The Double Ghetto: Canadian Women and their Segregated Work. Toronto: McClelland and Stewart.

---- (2008). About Canada: Health Care. Halifax: Fernwood Publishing.

Armstrong, P., Amaratunga, C., Bernier, J., Grant, K., Pederson, A., and K. Willson (Eds.). (2001). Exposing Privatization: Women and Health Care Reform in Canada. Aurora, Ontario: Garamond Press. 
Arrighi, G. (1994). The Long Twentieth Century. Money, Power and the Origins of Our Times. New York: Verso.

Aronowitz, S. (2000). The Knowledge Factory: Dismantling the Corporate University and Creating True Higher Learning. Boston: Beacon Press.

Arthurs, H.W. (1971). Collective Bargaining By Public Employees in Canada: Five Models. Ann Arbor: University of Michigan-Wayne State University.

Astin, T.H. and C.H.E. Philpin (Eds.). (1985). The Brenner Debate: Agrarian Class Structure and Economic Development in Pre-Industrial Europe. Cambridge: University of Cambridge.

Azoulay, D. (2000). The CCF and Post-Second World War Politics in Ontario. In E.A. Montigny and L. Chambers (Eds.), Ontario Since Confederation: A Reader (pp.362-380). Toronto: University of Toronto Press.

Azzi, S. (1999). Walter Gordon and the Rise of Canadian Nationalism. Montreal and Kingston: McGill-Queens University Press.

Bakan, A and D. Stasilus (Eds.). (1997). Not One of the Family: Foreign Domestic Workers in Canada. Toronto: University of Toronto Press

Bakker, I, ed. (1996). Rethinking Restructuring: Gender and Change in Canada. Toronto: University of Toronto Press.

Baluja, T. (5 November 2011). The Downside of a City that Just Keeps Growing. Globe \& Mail. http://www.theglobeandmail.com/news/national/toronto/globe-to/the-down- side- ofa-city-that-just-keeps-growing-up/article2226336/

Bannerji, H. (2000). The Dark Side of the Nation: Essays on Multiculturalism, Nationalism and Gender. Toronto: Canadian Scholars' Press. 
Banting, K. (1986). State and Society: Canada in Comparative Perspective. Toronto: University of Toronto Press.

Baragar, F. (2009). Canada \& the Crisis. In Guard, J. \& W. Antony( Eds.), Bankruptcies \& Bailouts (pp.77-106). Halifax: Fernwood.

Baragar, F. \& M. Seccareccia. (2008). Financial Restructuring: Implications of Recent Canadian Macroeconomic Developments. Studies In Political Economy, 82, 61-83.

Baran, P.A. and P.M. Sweezy. (1969). Monopoly Capital: AN Essay on the American Economic and Social Order. New York: Monthly Review Press.

Barnett, J. and C. Fanelli. (2009). Lessons Learned: Assessing the 2009 City of Toronto Strike \& Its Aftermath. New Socialist, 64, 26-30.

Bartlett, B. (1984). Keynes as a Conservative. Modern Age, 28, 128-133.

----- (2009). Keynes Was Really A Conservative. Forbes. http://www.forbes.com/2009/08/13/john-maynard-keynes-conservative-opinionscolumnists-bruce-bartlett.html

Bashevkin, S. (2006). Tales of Two Cities: Women and Municipal Restructuring in London and Toronto. Vancouver: University of British Columbia Press.

Battle, K., S. Torjman, M. Mendelson, and E. Tamagno. (2007). Mixed Brew for the 'Coffee Shop' Budget. Ottawa: Caledon Institute of Social Policy.

Beckstead, D. and T. Vinodrai. (2003). Dimensions of Occupations Changes in Canada's Knowledge Economy, 1971-1996. Statistics Canada, Catalogue no. 11-622-MIE - 004

Bello, W. (2009). Keynes: A Man for this Season? Foreign Policy in Focus, http://www.fpif.org/articles/keynes_a_man_for_this_season 
Benzie, R. (2010, June 22). Dalton McGuinty confirms 'SuperCorp' being considered. Toronto Star. http://www.thestar.com/news/ontario/article/827135--dalton-mcguinty-confirmssupercorp-being-considered.

Benzie, R., and P. Maloney. (2010, March 26). McGuinty to Cities: Freeze Wages. Toronto Star. http://www.thestar.com/news/ontario/ontariobudget/article/786092--mcguinty-to-citiesfreeze-wages.

Benzie, R., and R. Ferguson (2010, September 16). Arbitrator Rules Against Wage Freeze, Liberals Scoff. Toronto Star. http://www.thestar.com/news/canada/article/862403-arbitrator-rules-against-wage-freeze-liberals-scoff

Bercuson, D.J. (1990). Confrontation at Winnipeg: Labor, Industrial Relations and the General Strike. Montreal: McGill-Queens Press.

Bernard, A., and D. Galarneau. (2010). Layoffs in Canada. Statistics Canada. Statistics Canada, Catalogue no. 75-001-X

Bernier, J. and M. Dallaire. (2001). What Price Have Women Paid for Health Care Reform? The Situation in Quebec. In Armstrong, P., Amaratunga, C., Bernier, J., Grant, K., Pederson, A., and K. Willson (Eds.), Exposing Privatization: Women and Health Care Reform in Canada (pp.121-153). Aurora, Ontario: Garamond Press.

Berton, P. (2001). The Great Depression: 1929-1939. Toronto: Anchor.

Bezanson, K. (2010). "Childcare Delivered Through the Mailbox:" Social Reproduction, Choice, and Neoliberalism in a Theo-Conservative Canada. In Braedley, S. and M. Luxton (Eds.), Neoliberalism and Everyday Life (pp.90-112) Montreal \& Kingston: McGill-Queens University Press.

Bezanson, K, and M. Luxton (Eds.). (2006). Social Reproduction: Feminist Political Economy Challenges Neoliberalism. Montreal \& Kingston: McGill-Queen's University Press. 
Biddle, J.B (Ed.). (2001). Social Class, Poverty and Education: Policy and Practice. New York: Routledge.

Blatt, S. (2009, October 30). Legal communication.

http://www.psacafpc.org/documents/bargaining/oct30letter_facebook_issue-e.pdf

Blizzard, C. (1995). Right Turn: How the Tories Took Ontario. Toronto: Dunburn Press.

Block, S. and G.E. Galabuzi. (2011). Canada's Colour Coded Labour Market: The Gap for Racialized Workers. Ottawa: Canadian Centre for Policy Alternatives.

Boudreau, J.A. (2000). The Megacity Saga. Nova Scotia: Black Rose Books.

Boudreau, J.A., R. Keil \& D. Young. (2009). Changing Toronto: Governing Urban Neoliberalism. Toronto: University of Toronto Press.

Boyd, S (Ed.). (1997). Challenging the Public/Private Divide: Feminism, Law and Public Policy. Toronto: University of Toronto Press.

Boyer, R. (1996). State and Market: A New Engagement for the Twenty-First Century? In R. Boyer and D. Drache (Eds.), States Against Markets: The Limits of Globalization (pp. 84-116). New York: Routledge.

Bradford, N. (2007). Placing Social Policy? Reflections on Canada's New Deal for Cities and Communities. Canadian Journal of Urban Research, 16(2), 1-26

Braedley, S., and M. Luxton (Eds.). (2010). Neoliberalism and Everyday Life. Montreal \& Kingston: McGill-Queen's University Press.

Brassard, R. (2009, November 15). Personal Communication.

Braverman, H. (1998). Labor and Monopoly Capital: The Degradation of Work in the Twentieth Century. New York: Monthly Review Press.

Brenan, J. (2012). Enhancing Democratic Citizenship, Deepening Distributive Justice: The Living Wage Movement. Ottawa: Canadian Centre for Policy Alternatives. 
Brenner, N. (1999). Globalization as Reterritorialization: The Rescaling of Urban Governance in the European Union. Urban Studies, 36 (3), 431-451.

Brenner, R. (2006). The Economics of Global Turbulence. London: Verso.

Brenner, N. \& N. Theodore, eds. (2002). Spaces of Neoliberalism: Urban Restructuring in North America \& Western Europe. Oxford: Blackwell.

Brenner, N., J. Peck and N. Theodore. (2010). Variegated Neoliberalization: Geographies, Modalities, Pathways. Global Networks, 10 (2), 182-222.

Brewster, M. (2012, August 21). F-35 Scandal: Canada's Procurement Of Jets Slammed By Critics. Huffington Post. http://www.huffingtonpost.ca/2012/08/21/f-35-scandalcanada_n_1818727.html

Briskin, 1. (2007). "Public Sector Militancy, Feminization, and Employer Aggression: Trends in Strikes, Lockouts, and Wildcats in Canada from 1960 to 2004." In Dribbusch, H., D. Lyddon, K. Vandaele and S. van der Velden (eds.), Strikes Around the World (pp. 86113). Amsterdam: Aksant.

Briskin, L. and P. McDermitt. (1993). Women Challenging Unions: Feminism, Democracy and Militancy. Toronto: University of Toronto Press.

British Broadcasting Corporation. (2010, 24 November). Student Tuition Fees Protests Across $U K$. http://www.bbc.co.uk/news/education-11828882

Broad, D. (2000). Hollow Work, Hollow Society? Globalization and the Causal Labour Problem in Canada. Halifax: Fernwood Publishing.

Broad, D. and G. Hunter. (2010). Work, Welfare, and the New Economy: The Commodification of Everything. In N. Pupo and M. Thomas (Eds.), Interrogating the New Economy: Restructuring Work in the 21st Century (pp.21-42). Toronto: University of Toronto Press. 
Broad, D. and W. Antony, eds. (2006). Capitalism Rebooted: Work, Welfare, and the New Economy. Halifax: Fernwood.

Broad, D. and G. Hunter. (2010). "Work, Welfare, and the New Economy: The Commodification of Everything." In Pupo, N. and M.P. Thomas (eds.), Interrogating the New Economy: Restructuring Work in the 21st Century (pp.21-42). Toronto: University of Toronto Press.

Brofenbrenner, K. S. Friedman, R. W. Hurd, R.A. Oswald and R. L. Seebeer (Eds.). Organizing to Win: New Research on Union Strategies. New York: Cornell University Press.

Brown, L. (2010, October 12). Ruling Gives U of T Profs 4.5\% Over Two Years. Toronto Star. http://www.thestar.com/news/canada/article/874373

Burda, C. and G. Haines. (2011). Making Tracks to Torontonians. Toronto: Pembina Institute. Burke, M., C. Mooers and J. Shields (Eds.). (2000). Restructuring and Resistance: Canadian Public Policy in an Age of Global Capitalism. Halifax: Fernwood Publishing.

Burton, P. (1990). The Great Depression: 1929-1939. Toronto: Anchor.

Callinicos, A. (2010). Bonfire of Illusions: The Twin Crises of the Liberal World. Cambridge: Polity Press.

Camfield, D. (2011). The 'Great Recession', the Employers' Offensive and Canadian Public Sector Unions. Socialist Studies, 7 (1/2), 95-115.

----- (2011b). Lessons From the Canada Post Lockout. Rabble.

http://rabble.ca/blogs/bloggers/behind-numbers/2011/07/lessons-canada-post-lockout

(2008). The Working Class Movement in Canada: An Overview. In Smith, M (ed.), Group Politics and Social Movements in Canada (61-84). Peterborough: Broadview.

Campbell, B. (2009). The Global Economic Crisis and Its Canadian Dimension. Ottawa: Canadian Centre for Policy 
Campbell, P. (1999). Canadian Marxists and the Search for a Third Way. Montreal and Kingston: McGill-Queens Press.

Campbell, R.M. (1987). Grand Illusions: The Politics of the Keynesian Experience in Canada, 1945-1975. Peterborough, ON: Broadview Press.

Campion-Smith, B. and K. Wallace. (2012, March 2). Robo-Calls: Elections Canada Logs 31,000 Reports in Robo-Call Scandal. Toronto Star. http://www.thestar.com/news/canada/politics/article/1139845--elections-canada-logs-31000-complaints-in-robo-call-scandal

Canadian Association of University Teachers. (2006). CAUT Almanac of Post-Secondary Education in Canada. Ottawa: CAUT Publications.

Canadian Labour Congress. (2012). What Did Corporate Tax Cuts Deliver? Background Report for Corporate Tax Freedom Day 2012. http://www.canadianlabour.ca/sites/default/files/whatdid-corporate-tax-cuts-deliver-2012-01-12-en.pdf

Canadian Union of Public Employees 3908. (2010). Collective Agreement 2010-2013, Unit 1. http://cupe3908.org/index.php?id=57

Canadian Federation of Students Ontario. (2012). The Future of Ontario's Post-Secondary Education System. http://cfsontario.ca/downloads/CFS-2012.10-StudentsVision.pdf Canadian Union of Postal Workers. (2012, August 8). Arbitrator Bias Upheld By Court. http://www.cupw.ca/index.cfm/ci_id/14236/la_id/1.htm

Canadian Union of Postal Workers. (2012, January 30). CUPW Wins Again. http://www.newswire.ca/en/story/912517/cupw-wins-again-federal-court-throws-out-lisaraitt-s- arbitrator

Canadian Union of Public Employees-Ontario University Workers Coordinating Committee. (n.d.). University. http://www.cupe.on.ca/s36/university 
Canadian University Press. (2012, February 29). Ontario Government Recommends Online Classes to Save Money. http://cupwire.ca/articles/51829

Caplan, G. (1973). The Dilemma of Canadian Socialism: The CCF in Ontario. Toronto: McClelland and Stewart.

Carleton University Graduate Student Association/Canadian Federation of Students. (2010-11). Member Handbook. Burnaby, British Columbia: Mitchell Press.

Carroll, W.K. (1986). Corporate Power and Canadian Capitalism. Vancouver: University of British Columbia Press. (2004). Corporate Power in a Globalizing World. Oxford: Oxford University Press.

Carroll, W. K., \& Shaw, M. (2001). Consolidating a Neoliberal Policy Bloc in Canada, 19761996. Canadian Public Policy, 27, 195-217.

Carroll, W.K. and C. Carson. (2003). Forging a new hegemony? The role of transnational policy groups in the network and discourses of global corporate governance. Journal of WorldSystems Research, 9 (1), 67-102

Carroll, W.K., \& R.S. Ratner (Eds.). (2005). Challenges and Perils: Social Democracy in Neoliberal Times. Halifax: Fernwood Publishing.

Carson, J. (2011). Two Steps Forward, One Step Back: Legislating Labour Relations in the Ontario Public Service. Paper Presented at the 2009 meetings of the Canadian Political Science Association. Available at http://www.cpsa-acsp.ca/papers-2009/Carson.pdf Caulfield, J. (2010). The Form of the City. In Hiller, H.H. (Ed.), Urban Canada, second edition (pp.324-352). Toronto: Oxford University Press.

-.-- (1994). City Form and Everyday Life: Toronto's Gentrification and Critical Social Practice. Toronto: University of Toronto Press. 
CBC News. (2007a, October 11). McGuinty Wins Massive Majority, Tory Loses Seat.

http://www.cbc.ca/canada/ontariovotes2007/story/2007/10/10/leaders.html

----- (2007b, October 11). Ontario Voter Turnout a Record Low.

http://www.cbc.ca/canada/ontariovotes2007/story/2007/10/11/ov-turnout- 071010.html

----- (2007c, October 11). Ontario Rejects Electoral Reform in Referendum.

http://www.cbc.ca/canada/ontariovotes2007/story/2007/10/10/mmp-referendum.html

----- (2009a, November 12). War Museum Pickets Honour Remembrance Day.

http://www.cbc.ca/news/canada/ottawa/story/2009/11/11/war-museum.html

---- (2009b, October 22). Striking museum workers spoof exhibit.

http://www.cbc.ca/news/canada/ottawa/story/2009/10/22/ottawa-museum- workersspoof-exhibit.html

(2009c, October 7). E-Health scandal a \$1B waste: auditor.

http://www.cbc.ca/news/canada/toronto/story/2009/10/07/ehealth-auditor.html

---- (2010, May 26). Summit Costs Hit \$1.1B. CBC News.

http://www.cbc.ca/news/politics/story/2010/05/26/g8-g20-security-summit-toews.html

(2003, December 4). Air Canada Granted Bankruptcy Protection.

http://www.cbc.ca/news/story/2003/04/01/aircan030401.html

(2012, February 23). Ontario Universities Urged to Move More Classes Online.

http://www.cbc.ca/news/canada/ottawa/story/2012/02/23/ontario-online-post-secondaryclasses-report.html

Certified General Accountants Association of Canada. (2009). Where is the Money Now: The State of Canadian Household Debt as Conditions for Economic Recovery Emerge. http://www.cga-canada.org/en-ca/ResearchReports/ca_rep_2010-05_debt-consumption.pdf. 
Chan, P.C.W., R. Morisette and M. Frenette. (2011). Workers Laid-off During the Last Three Recessions: Who Were They, and How Did They Fare? Statistics Canada, Catalogue no. 11F0019M - 337

Choudry, A. J. Hanley, S. Jordan, E. Shragge and M. Stiegman. (2009). Fight Back: Workplace Justice for Immigrants. Halifax: Fernwood

Church, E. and P. White. (17 May 2011). Ford's Plan to Privatize Garbage Collection Passes:

With Concessions. Globe \& Mail. http://www.theglobeandmail.com/news/toronto/fordsplan-to-privatize-garbage-collection-passes---with-concessions/article4262961/

City of Toronto. (2007). Why One Cent?, Retrieved on December 222009 from, http://www.onecentnow.ca/why-one-cent.html

---- (2008). Mayor's Fiscal Review Panel.

http://www.toronto.ca/david_miller/pdf/blueprint_highlights_20080217.pdf

----- (2009). 2009 Operating Budget. http://www.toronto.ca/budget2009/

-...- (2010). 2010 Operating Budget.

http://www.toronto.ca/budget2010/pdf/op2010_presentation_exec_april7.pdf

----- (2011). 2011 Operating Budget.

http://www.toronto.ca/legdocs/mmis/2011/bu/bgrd/backgroundfile-35804.pdf

----- (2011). Solid Waste Management Services Garbage Collection Request for

Quotations(RFQs). http://www.toronto.ca/legdocs/mmis/2011/pw/bgrd/backgroundfile37155.pdf

-.-.- (2011b). City Managers Report to Standing Committees.

http://www.toronto.ca/torontoservicereview/results.htm

----.. (n.d.). Business Facts. http://www.toronto.ca/toronto_facts/business_econdev.htm 
Clarke, J. (2008). Out of Sight, Out of Mind. The Bullet, http://www.socialistproject.ca/bullet/bullet134.html

Clarke, S. (2005). The Neoliberal Theory of Society. In Saad-Filho, A. \& D. Johnston, eds., Neoliberalism: A Critical Reader (pp.50-59). London: Pluto Press.

CLC. (2009, October 28). CLC supports striking museum workers. http://www.canadianlabour.ca/national/news/clc-supports-striking-museum-workersasks-union-members-not-visit-civilization-and-war

Clement, W. (1975). The Canadian Corporate Elite: An Analysis of Economic Power. Toronto: McClelland and Stewart.

---- (1981). Hardrock Mining: Industrial Changes and Technological Changes at Inco. Toronto: McClelland and Stewart.

----- (2007). Methodological Considerations: Thinking about Researching Work. In V. Shalla and W. Clement (Eds.), Work in Tumultuous Times (pp.30-51) Montreal and Kingston: McGill-Queen's University Press.

Clement, W. (1977). Continental Corporate Power: Economic Elite Linkages Between Canada and the United States. Toronto: McClelland and Stewart.

Clement, W. and G. Williams (Eds). (1989). The New Canadian Political Economy. Montreal \& Kingston: McGill-Queens University Press.

Clement, W. and J. Myles. (1994). Relations of Ruling: Class and Gender in Post-Industrial Societies. Montreal and Kingston: McGill-Queens University Press.

Clement, W., S. Mathieu, S. Prus and E. Uckardesler. (2010). Restructuring Work and Labour Markets in the New Economy: Four Processes. In N. Pupo and M. Thomas (Eds.), Interrogating the New Economy: Restructuring Work in the 21st Century (pp.43-64). Toronto: University of Toronto Press. 
CMCC. (2009, December 18). Dr. Victor Rabinovitch renewed as head of the Canadian Museum of Civilization Corporation. http://www.civilization.ca/cmc/media/press- releases/2009/drvictor-rabinovitch-renewed-as-head-of-the-canadian-museum-of- civilization-corporation

Cobb, C. (2011, June 17). PSAC to mount campaign against federal job cuts." Vancouver Sun. $\mathrm{http}: / /$ www.vancouversun.com/news/PSAC+mount+campaign+against+federal $+\mathrm{c}$ uts/4966648/story.html

Cockett, R. (1995). Thinking the Unthinkable: Think Tanks and the Economic CounterRevolution, 1931-1983. London: Fontana Press.

Cohn, M.R. (2012, April 25). ORNGE Mess a Sorry Tale of Bad Judgment, Human Error. Toronto Star. http://www.thestar.com/news/canada/politics/article/1168112--cohn-orngemess-a-sorry-tale-of-bad-judgment-human-error

Colling, H. (1995). The Ford Strike in Windsor: 99 Days. Toronto: NC Press.

Collins, L.J. (2003). Gender, Labor, and Power in the Global Apparel Industry. Chicago: University of Chicago Press.

Colour of Poverty. (2007). Understanding the Racialization of Poverty in Ontario. http://www.colourofpoverty.ca.

Colvin, J. (2010). Neither Side of Strike Spared Citizens' Wrath. Globe \& Mail. http://www.theglobeandmail.com/news/toronto/neither-side-of-strike-spared-citizenswrath/article4281882/

Commission of Inquiry into the Sponsorship Program and Advertising Activities. (2005). Ottawa: Queen's Printer.

Commission on the Reform of Ontario's Public Services. (2012). Public Services for Ontarians: A Path to Sustainability and Excellence. Toronto: Queens Printer for Ontario. 
Conference Board of Canada. (2011). Canadian Income Inequality.

http://www.conferenceboard.ca/hcp/hot-topics/canInequality.aspx\#ftn1

Connell, R. (2010). Understanding Neoliberalism. In Braedley, S., and M. Luxton (Eds.), Neoliberalism and Everyday Life. (pp.22-36). Montreal \& Kingston: McGill-Queen's University Press

Cooke, M. (2012). Teachers' Strikes and the Fight Against Austerity in Ontario. The Bullet. http://www.socialistproject.ca/bullet/758.php

Council of Ontario Universities. (2012). Transforming Ontario Universities. http://www.cou.on.ca/publications/reports/pdfs/transforming-ontario-universities----cousubmissio

Council of Ontario Universities. (2012). Transforming Ontario Universities.

http://www.cou.on.ca/publications/reports/pdfs/transforming-ontario-universities----cousubmissio

Corman, J. and M. Luxton. (2007). Social Reproduction and the Changing Dynamics of Unpaid Household and Caregiving Work. In Shalla, V. and W. Clement (Eds.), Work In Tumultuous Times (pp.262-288). Montreal and Kingston: McGill-Queens University Press.

Cormier, J. (2004). The Canadianization Movement: Emergence, Survival and Success. Toronto: University of Toronto Press.

Couchene, T.J. and C.R. Telmer. (1998). From Heartland to North American Region State: The Social, Fiscal and Federal Evolution of Ontario, an Interpretive Essay. Toronto: University of Toronto Press. 
Cox, B. (2012, February 27). Mr. Harper, Dissent is Vital to Democracy. Globe \& Mail. http://www.theglobeandmail.com/commentary/mr-harper-dissent-is-vital-todemocracy/article552157/

Craven, P. (1980). "An Impartial empire": Industrial Relations and the Canadian State, 19001911. Toronto: University of Toronto Press.

Cresse, G. (2007).Racializing Work/Reproducing White Privilege. In Shalla, V. and W. Clement (Eds.), Work In Tumultuous Times (pp192-226). Montreal and Kingston: McGill-Queens University Press.

Cross, P. (2011). Statistics Canada: How Did the 2008-10 Recession and Recovery Compare With Previous Cycles? http://www.statcan.gc.ca/pub/11-010-x/2011001/part-partie3eng.htm

Crown Employees Collective Bargaining Act.. (1972). Toronto: Queen's Printer.

CTV News. (2011, June 27). Angry postal workers rally before returning to work. http://www.ctv.ca/CTVNews/TopStories/201 10627/strike-canada-post-mail-deliveryresuming-tuesday-110627/

CTV News. (2011b, March 4). Canadians Still Think Country Is In Recession: Poll. http://www.ctv.ca/CTVNews/Canada/20110304/recession-poll-110304/.

CUPE-OUWCC. (2010). Coordinating Our Future 2010. http://www.cupe.on.ca/a2638/OUWCC\%20Conference\%20Report-FINALDRAFT3.pdf da Silva, S. (2009). Bank Bailouts and the 2009 Federal Budget. Relay, 25, 6-9.

Dale, D. (2011, October 25). Ford Wants to Sell 10\% of Hydro. Toronto Star. http://www.thestar.com/news/article/1075440--ford-wants-to-sell-10-of-hydro 
(2011b,October 27). Council Approves Some Cuts, Rejects Others. Toronto Star.

http://www.thestar.com/news/torontocouncil/article/1060430--council-approves-somecuts-rejects-others

----- (2011c, September 15). Ford Says City Employees Are the 'Gravy'. Toronto Star. http://www.thestar.com/news/article/1054349

Das Gupta, T. (1996). Racism and Paid Work. Toronto: Garamond Press.

Dawson, R. (1929). The Civil Service of Canada. Oxford: Oxford University Press.

Department of Finance. (2010, September 9). Minister of Finance Highlights Budget Measure to Cut Red Tape and Boost Venture Capital for Canadian Firms. http://www.fin.gc.ca/n10/10-079-eng.asp

Desai, R. (2009). Keynes Redux: History Catches Up. ." In Guard, J. and W. Antony (Eds.), Bankruptcies and Bailouts (pp. 123-144). Halifax: Fernwood Publishing.

Desfor, G., R. Keil, S.Kipfer and G. Wekerle. (2006). From Surf To Turf: No Limits to Growth in Toronto? Studies in Political Economy, 77, 131-155

DiMaggio, A. (2010). When Media Goes to War: Hegemonic Discourse, Public Opinion and Limits of Dissent. New York: Monthly Review Press.

Dobbin, M. (1991). Preston Manning and the Reform Party. Toronto: James Lorimer and Company.

----- (24 May 2010). The Canadian 'Good Banks' myth. Vancouver Sun. http://blogs.vancouversun.com/2010/05/24/the-canadian-\%E2\%80\%98goodbanks $\% \mathrm{E} 2 \% 80 \% 99-$ myth/

Dobby, C. (2011, October 18). Toronto's Condo Boom About to Bust: Report. Financial Post. http://business.financialpost.com/2011/10/18/torontos-condo-boom-about- to-bust-report/ 
Donoghue, F. (2008). The Last Professors: The Corporate University and the Fate of the Humanities. New York: Fordham University Press.

Doolittle, R. (2011, May 5). Ford's Costly Police Deal 'Rookie Mistake', Critics Say. Toronto Star. http://www.thestar.com/news/article/986568

---- (2011b, September 16). Massive Poll Shows Toronto is United Against Ford Cuts. Toronto Star. http://www.thestar.com/news/torontocouncil/article/1054837--massive-poll-showstoronto-is-united-against-ford-s-proposed-cuts?bn=1

Duffy, A. and N. Pupo. (1992). Part-time Paradox: Connecting Gender, Work and Family. Toronto: McClelland and Stewart.

Duffy, A., D. Glenday and N. Pupo (Eds.). (1997). Good Jobs, Bad Jobs, No Jobs: The Transformation of Work in the 21st Century. Toronto: Harcourt Brace \& Company.

Dumenil, G. and D. Levy. (2001). Capital Resurgent: The Roots of the Neoliberal Revolution. Cambridge: Harvard University Press.

----- (2011). The Crisis of Neoliberalism. Cambridge: Harvard University Press.

Dylan, A. (2012). Safety in the Classroom: Safeguarding Liberal Arts Education from the NeoLiberal Threat. Canadian Journal of Higher Education, 42(2), 34-48.

Eagleton, T. (1996). Ideology: An Introduction. London: Verso.

Economic Fact Sheet. (2010). Canadian Social Trends. Statistics Canada, http://www.statcan.gc.ca/pub/11-008-x/2010001/article/11133-eng.htm

Edwards, P. (2003). One Dead Indian: The Premier, The Police and the Ipperwash Crisis. Toronto: Stodort Publishing.

Eley, G. (2002). Forging Democracy: The History of the Left in Europe 1850-2000. New York: Oxford University Press. 
Engels, F. (1845). The Condition of the Working Class in England.

http://www.marxists.org/archive/marx/works/1845/condition-working-class/ch10.htm

------ (1866). Letter to Wischnewetsky.

http://www.marxists.org/archive/marx/works/1886/letters/86_12_28.htm

(1871). Letter to Caffiero.

http://www.marxists.org/archive/marx/works/1871/letters/71_07_16.htm

---- (1881). Trade Unions. http://www.marxists.org/archive/marx/works/1881/05/28.htm

---- (1885). Letter to Gualliame-Schack.

http://www.marxists.org/archive/marx/works/1885/letters/85_07_05.htm

Esping-Anderson, G. (1990). The Three Worlds of Welfare Capitalism. New Jersey: Princeton University Press.

Evans, B. (2011). The Politics of Public Sector Wages: Ontario's Social Dialogue For Austerity. Socialist Studies, 7 (1/2), 171-190.

----- (2012). From Protest Movement to Neoliberal Management: Canada's New Democratic Party in the Era of Permanent Austerity. In Evans, B. and I. Schmidt (Eds.). Social Democracy After the Cold War (pp. 45-98). Edmonton: Athabasca University Press.

Evans, B. and G. Albo. (2010). Permanent Austerity: The Politics of the Canadian Exit Strategy From Fiscal Stimulus. Alternate Routes, 22, 7-28.

Evans, B. and J. Shields. (2011). "From Pragmatism to Neoliberalism: Ontario's Hesitant Farewell t o Dr. Keynes." In Dutil, P. (ed.), The Guardian of Finance: Perspectives on the Ministry of Finance in Ontario (pp.131-161). Toronto: University of Toronto Press.

Fanelli, C. (2009). The City of Toronto Fiscal Crisis: Neoliberal Urbanism \& the Reconsolidation of Class Power. Interdisciplinary Themes, 1 (1), 8-18 
------ (forthcoming, 2012). Renewing Working Class Politics: Marx's and Engels' Challenge to the Labour Movement: In Paulson, J., C. Fanelli, G. Ozcan and P. Lefebvre (Eds.), Capitalism and Confrontation: Critical Perspectives. Ottawa: Red Quill Books.

Fanelli, C. and J. Paulson. (2010). "Municipal Malaise: Neoliberal Urbanism in Canada." In L. Tepperman and A. Kalyta (eds.), Reading Sociology: Canadian Perspectives (pp.223-228). Toronto: Oxford University Press.

Fanelli, C. and P. Lefebvre. (2011). The Ottawa Museum Workers' Strike:

Precarious Employment and the Public Sector Squeeze. In Fanelli, C. and P. Lefebvre (Eds.), Uniting Struggles: Critical Social Research In Critical Times. Ottawa: Red Quill Books.

Fanelli, C. and J. Meades. (2011). Austerity, Ontario and Post-Secondary Education: The Case of “Canada’s Capital University." Journal of Critical Education Policy Studies, 9(2), 24-56.

Fanelli, C. and M.P. Thomas. (2011). Austerity, Competitiveness and Neoliberalism Redux: Ontario Responds to the Great Recession. Socialist Studies/Etudes Socialistes, 7 (1/2), $140-171$

Federation of Canadian Municipalities. (2006). Building Prosperity From the Ground Up: Restoring Municipal Fiscal Balance. http://www.canadascities.ca/pdf/2006_FCM_Building_Prosperity_from_the_Gro und_Up.pdf

----- (2012). Canada's Infrastructure Report Card: Vol. 1. http://www.fcm.ca/Documents/reports/Canadian_Infrastructure_Report_Card_EN.pdf Fenlon, B. (2007, October 11). Referendum on Electoral Reform an 'unmitigated disaster'. Globe and Mail. http://www.theglobeandmail.com/archives/article787661.ece 
Ferguson, R. and R. Benzie. (2010, November 5). Dalton Days': Premier Likes the Sound of That.Toronto Star. http://www.thestar.com/news/ontario/mcguinty/article/721403---daltondays-premier-likes-the-sound-of-that

Fernandez, L. (2009). “We're All Keynesians - Again.” In J. Guard and W. Antony (Eds.), Bankruptcies and Bailouts (pp. 107-122). Halifax: Fernwood Publishing.

Fernie, S. and D.Metcalf (Eds.). (2005). Trade Unions: Resurgence or Demise? The Future of Trade Unions in Britain. London: Routledge.

Fidler, R. (2011). The Federal NDP's Electoral Breakthrough in Quebec: A Challenge to Progressives in Canada. The Bullet. http:/www.socialistproject.ca/bullet/501.php

Fisher, D., Rubenson, K., Shanahan, T., Trottier, C., Bernatchez, J., Clift, R.(2006). Canadian Federal Policy and Post-Secondary Education. Vancouver: Centre for Policy Studies in Higher Education and Training.

Fitzpatrick, M. (2012, March 6). Tories Ditch 'In-and-Out' Case at Supreme Court. CBC News. http://www.cbc.ca/news/politics/story/2012/03/06/pol-supreme-court conservatives.html?cmp=rss

Fletcher Jr, B. and F. Gasparin (2008). Solidarity Divided: The Crisis in Organized Labor and A New Path Toward Social Justice. Berkeley: UC Press.

Fleischer, D. and N. Visschedyk. (n.d.). Concrete Problems: How To Fix Our Crumbling Infrastructure. Metroland Media News. http://www.metroland.com/page/Infrastructure Florida, R. (2002). The Rise of the Creative Class; And How Its Transforming Work, Leisure, Community and Everyday Life. New York: Basic Books.

Fodor, M. (2010). Fuelling the Tax Revolt: What's Wrong with the NDP's Anti-HST Campaign. The Bullet. http://www.socialistproject.ca/bullet/410.php Food Banks Canada. (2011). Hunger Count. Toronto: Food Banks Canada. 
Fong, P. (2009, June 9). Top Tory Curses Toronto. Toronto Star.

http://www.thestar.com/news/canada/article/647684--top-tory-curses-toronto

Foster, J.B. and F. Magdoff. (2009). The Great Financial Crisis: Causes and Consequences.

New York: Monthly Review Press.

Foster, K. (2012). Drummond, Deconstructed. Behind the Numbers: CCPA Blog. http://behindthenumbers.ca/2012/02/21/drummond-deconstructed/

Frankel, S.J. and R.C. Pratt. (1954). Municipal Labour Relations in Canada: A Study of Some Problems Arising from Collective Bargaining between Municipalities and Municipal Trade Unions. Toronto: Canadian Federation of Mayors and Municipalities.

Freeman, S. (2011, October 24). Air Canada request to review arbitrator deal violates collective agreement: CAW. Canadian Business. http://www.canadianbusiness.com/article/52873-air-canada-request-to-review-arbitrator-deal-violates-collective-agreement-caw

Friedman, M. (1962). Capitalism and Freedom. Chicago: University of Chicago Press.

Friedman, M. and R. Friedman. (1962). Capitalism and Freedom. Chicago: University of Chicago Press.

--- (1980). Free to Choose. Orlando, Florida: Harcourt Books.

Fiskin, F. (1993). Planning and Servicing the Greater Toronto Area: The Interplay of Provincial and Municipal Interests. In Rothblatt, D. and A. Sancton (eds.), Metropolitan Governance: American/Canadian Intergovernmental Perspectives (pp.153-204). Berkeley: University of California.

----- (2000).

Fudge, J. and E. Tucker. (2001). Labour Before the Law: The Regulation of Workers' Collective Action in Canada, 1900-1948. Toronto: Oxford University Press. 
Galabuzi, G.E. (2006). Canada's Economic Apartheid: The Social Exclusion of Racialized Groups in the New Century. Toronto: Canadian Scholars' Press.

Galbraith, J.K. (1958). The Affluent Society. New York: Houghton Mifflin Company.

---- (1987). Keynes, Roosevelt, and the Complementary Revolutions. Challenge, 30 (6), 19-23.

Gamble, A. (1994). The Free Economy and the Strong State: The Politics of Thatcherism. London: Macmillan.

Gattinger, M. and D. Saint-Pierre. (2010). The "Neoliberal Turn" in Provincial Cultural Policy and Administration in Quebec and Ontario: The Emergence of Quasi-Neoliberal Approaches. Canadian Journal of Communications, 35, 279-302

Georgious, C. (2010). The Euro Crisis and the Future of European Integration. International Socialism, 128, http://www.isj.org.uk/index.php4?id=682\&issue $=128$

Gidney, R.D. (1999). From Hope to Harris: The Reshaping of Ontario's Schools. Toronto: University of Toronto Press.

Gilmore, J. and S. Larochelle-Cote. (2011). Inside the Labour Market Downturn. Statistics Canada, Catalogue no. 75-001-X

Gindin, S. (1995). The Canadian Auto Workers: Birth and Transformation of a Union. Toronto: James Lorimer and Company.

----- (2001). Comment: Rebuilding the Left: Towards a Structured Anti-Capitalist Movement. Studies in Political Economy, 64, 91-97.

Gindin, S. (2004). The Auto Industry: Concretizing Working Class Solidarity: Internationalism Beyond Slogans. Toronto: Socialist Project.

----- (forthcoming, 2012). Rethinking Unions, Registering Socialism. Socialist Register, 2013. London: Merlin Press. 
Gindin, S. and J. Stanford. (2006). Canadian Labour and the Political Economy of Transformation. In V. Shalla (Ed.), Working in a Global Era: Critical Perspectives (pp.379-394). Toronto: Canadian Scholars Press Index.

Globe and Mail. (2012, October 6). Canada Post, Workers Reach Tentative Deal. http://www.theglobeandmail.com/news/world/canada-post-workers-reach-tentativedeal/article4594506/

Good Jobs For All. (n.d.). Rights and Dignity at Work. http://goodjobsforall.ca/rights-dignity-atwork/

Goldfield, M. and B. Palmer. “Canada's Workers Movement: Uneven Developments.” Labour/Le Travail 59 (2007): 149-178.

Gonick, C. (1987). The Great Economic Debate: Failed Economics and a Future for Canada. Toronto: James Lorimer.

----- (2009). A Great Leap Forward? In J. Guard and W. Antony (Eds.), Bankruptcies and Bailouts (pp. 8-17). Halifax: Fernwood Publishing.

Gordon, W.L. (1966). A Choice for Canada: Independence or Colonial Status. Toronto: McClelland and Stewart.

Government of Canada. (2006). Budget Plan. http://fin.gc.ca/budtoc/2006/budlist-eng.asp

----- (2007). Budget Plan. http://www.budget.gc.ca/2007/index-eng.html

---- (2008). Budget Plan. http://www.budget.gc.ca/2008/home-accueil-eng.html

----- (2009). Budget Plan. http://www.budget.gc.ca/2009/home-accueil-eng.html

---- (2010). Budget Plan. http://www.budget.gc.ca/2010/home-accueil-eng.html

----- (2011). Budget Plan. http://www.budget.gc.ca/2011/home-accueil-eng.html

Government of Ontario. (1985). Ontario Budget.

http://archive.org/stream/ontariobudget1985onta\#page/n3/mode/2up 
-.--- (1986). Ontario Budget. http://archive.org/stream/ontariobudget1986onta\#page/n3/mode/2up

----- (1987). Ontario Budget. http://archive.org/stream/ontariobudget1987onta\#page/n3/mode/2up

----- (1988). Ontario Budget. http://archive.org/stream/ontariobudget1988onta\#page/n3/mode/2up

---- (1989). Ontario Budget. http://archive.org/stream/ontariobudget1989onta\#page/n5/mode/2up

-.-.- (1995). Ontario Budget. http://archive.org/stream/ontariobudget1995onta\#page/n1/mode/2up

----- (1996). Ontario Budget. http://www.fin.gov.on.ca/en/budget/ontariobudgets/1996/a-tax.html (1997). Ontario Budget. http://www.fin.gov.on.ca/en/budget/ontariobudgets/1997/bud-

pa_html

(1998). Ontario Budget.

http://www.fin.gov.on.ca/en/budget/ontariobudgets/1998/98paper.html (1999). Ontario Budget.

http://www.fin.gov.on.ca/en/budget/ontariobudgets/1999/99paper.html

----- (2004). Ontario Budget: The Plan for Change.

http://www.fin.gov.on.ca/en/budget/ontariobudgets/2004/pdf/papers_all.pdf

----- (2005). Ontario Budget: Investing In People, Strengthening our Economy.

http://www.fin.gov.on.ca/en/budget/ontariobudgets/2005/pdf/papers_all.pdf

----- (2006). Ontario Budget: Building Opportunity.

http://www.fin.gov.on.ca/en/budget/ontariobudgets/2006/pdf/statement.pdf.

---- (2007). Ontario Budget: Investing In People and Expanding Opportunity.

http://www.fin.gov.on.ca/en/budget/ontariobudgets/2007/pdf/papers_all.pdf

---- (2008). Ontario Budget: Growing a Stronger Ontario.

http://www.fin.gov.on.ca/en/budget/ontariobudgets/2008/pdf/papers_all.pdf

-----(2009). Ontario Budget: Confronting the Challenge, Building our Economic Future.

http://www.fin.gov.on.ca/en/budget/ontariobudgets/2009/papers_all.pdf. 
-- (2010). A Stronger Canada. A Stronger Economy. Now and For the Future.

http://www.discours.gc.ca/grfx/docs/sft-ddt-2010_e.pdf

----- (2011). A Low-Tax Plan for Jobs and Growth.

http://www.budget.gc.ca/2011/plan/Budget2011-eng.pdf

---- (2010a).Ontario Budget: Open Ontario: Ontario's Plan for Jobs and Growth.

http://www.fin.gov.on.ca/en/budget/ontariobudgets/2010/papers_all.pdf

---- (2010b) An Act to Promote Ontario as Open for Business by Amending or Repealing

Certain Acts. Schedule 9. Toronto: Government of Ontario.

-.-.- (2010c). Ontario Budget: Open Ontario: Ontario's Plan for Jobs and Growth.

http://www.fin.gov.on.ca/en/budget/ontariobudgets/2010/papers_all.pdf

Gowan, P. (1999). The Global Gamble: Washington's Faustian Bid for World Dominance.

London: Verso

Grant, G. (2000). Lament for a Nation: The Defeat of Canadian Nationalism. Montreal and Kingston: McGill-Queens University Press.

Grant, T. (2011a, February 23). Labour Market Regains Zip, But Scars Still Linger. Globe and Mail. http://www.theglobeandmail.com/report-on-business/economy/jobs/labour-marketregains-zip-but-scars-linger/article1917112/

---- (2011b, March 4). Black Canadians Paid On Average Less Than Whites: Study. Globe and Mail. http://www.theglobeandmail.com/report-on-business/economy/economy-lab/dailymix/black-canadians-paid-less-on-average-than-whites-study/article1929847/

Grinspun, R. and R. Kreklewich. (1994). Consolidating Neoliberal Reforms: "Free Trade" as a Conditioning Framework. Studies in Political Economy, 43, 33-61. 
Gurney, M. (2011, May 12). McGuinty An Odd One to Criticize Toronto's Union Contracts.

National Post. http:/fullcomment.nationalpost.com/2011/05/12/matt-gurney-mcguinty-astrange-one-to-criticize-torontos-overly-generous-police-union-contract/

Hackworth, J. (2008). The Durability of Roll-Out Neoliberalism Under Centre-Left Governance.

Studies in Political Economy, 81, 7-26

Ha Thanh, H. (2011, September 16). Ford Support Falls As Toronto Residents Overwhelmingly Reject Service Cuts: Poll. Globe \& Mail.

http://www.theglobeandmail.com/news/national/toronto/ford-support-falls-as-torontoresidents-overwhelmingly-reject-service-cuts-poll/article2168563/

Halifax: Fernwood.

Hamowy, R. (1982). The Hayekian Model of Government in an Open Society. Journal of Libertarian Studies, 6 (2), 137-143.

Hanes, A. (2008, May 9). Property tax cuts 'right thing to do'. National Post. http://www.canada.com/story_print.html?id=3b36ad3e-8e74-4fo5-bef908d6bf0ff86a\&sponsor=

Hanson, A. (2009). Achieving the Right to Strike: Ontario Teachers' Unions and Professionalist Ideology. Just Labour: A Canadian Journal of Work and Society, 14, 117-128.

Harris, R.C. (1966). The Seigniorial System in Early Canada: A Geographical Study. Madison: University of Wisconsin.

Harmes, A. (2006). "Neoliberalism and Multilevel Governance." Review of International Political Economy, $13(5), 725-749$.

Harvey, D. (2005). A Brief History of Neoliberalism. Oxford: Oxford University Press.

--- (2008). The Right to the City. New Left Review, 53, http://newleftreview.org/II/53/davidharvey-the-right-to-the-city 
Hayek, F.A. (1944). The Road to Serfdom. New York: Routledge.

Heilbroner, R.L. (1999). The Worldly Philosophers: The Lives, Times and Ideas of the Great Economic Thinkers. New York: Touchstone.

Heisz, A. (2007). Income Inequality and Redistribution in Canada: 1976 to 2004. Statistics Canada, Catalogue no. 11F0019-298.

Heinrich, E. (2012). Toronto To Overtake London As a Hub for Bankers. Global Finance. http://www.gfmag.com/archives/146-january-2012/11539-toronto-to-overtake-london-as-ahub-for-bankers.html\#axzz2CsU2m1tT

Heron, C. (1996). The Canadian Labour Movement: A Short History, third edition. Toronto: James Lorimer and Company.

Hiller, H.H (ed,). (2010). Urban Canada. Toronto: Oxford University Press.

Hillyard-Little, M.J. (1998). No Car, No Radio, No Liquor Permit: The Moral Regulation of Single Mothers in Ontario, 1920-1997. Toronto: Oxford University Press.

Hobsbawm, E. (1994). The Age of Extremes: The Short Twentieth Century, 1914-1991. London: Michael Joseph.

Hobson, J.A. (1965). Imperialism: A Study. Ann Arbor: University of Michigan Press.

Hodgetts, J.E. (1973). The Canadian Public Service: A Physiology of Government, 1867-1970. Toronto University of Toronto Press.

----- (1995). From Arm's Length to Hands-On: The Formative Years of Ontario's Public Service, 1867-1940. Toronto: University of Toronto Press.

Hodgetts, J.E., W. McCloskey, R. Whitaker and V.S. Wilson. (1972). The Biography of an Institution: The Civil Service Commission of Canada, 1908-1967. Montreal and Kingston: McGill-Queens University Press. 
Howlett, K. (24 September, 2007). Referendum? Now what referendum would that be? Globe \& Mail. http://www.theglobeandmail.com/archives/article783471.ece

Human Resources and Skills Development Canada. (2010). Collective Bargaining in Canada 2010. Statistics Canada, Catalogue no. HS21-5/2011E-PDF (2012). Strategic Policy, Analysis, and Workplace Information Directorate.

http://srv131.services.gc.ca/dimt-wid/pcat-cpws/recherche-search.aspx?lang=eng (2012b). Union Coverage in Canada 2011. Statistics Canada, Catalogue no. HS21-5/2011EPDF

Hudson, B. (2003). Justice in the Risk Society. London: Sage.

Hull, J.P. (1994). The Second Industrial Revolution and the Staples Frontier in Canada. Rethinking Knowledge and History. Canadian Journal of the History of Science, Technology and Medicine, 18(1), 22-37.

Hulchanski, D. (2010). The Three Cities Within Toronto. http://www.urbancentre.utoronto.ca/pdfs/curp/tnrn/Three-Cities-Within-Toronto-2010Final.pdf

Hulsemeyer, A. (2000). Changing 'Political Economies of Scale' and Public Sector Adjustment: Insights from Fiscal Federalism. Review of International Political Economy 7(1), 72-100. Hume, C. (2011, July 11). Cuts Loom As Budget Season Kicks Off. Toronto Star. http://www.thestar.com/news/article/1023213--hume-cuts-loom-as-budget-seasonkicks-off

---- (2008, September 15). Ottawa 'leaders' Ignore Cities. Toronto Star. http://www.thestar.com/federalelection/article/499298 
Hume, S. (2011, July 15). Income Polarization a Recipe for Class War. Vancouver Sun. http://www.vancouversun.com/business/Income+polarization+recipe+class/5107000/stor y.html

Hunt E.K. and M. Lautzenheiser. (2011). History of Economic Thought: A Critical Perspective, third edition. New York: M.E. Sharp.

Hunter, G. and D. Miazdyck-Shield. (2006). "From Welfare to Workfare: Public Policy for the New Economy." In Broad, D. and W. Antony (eds.), Capitalism Rebooted: Work, Welfare and the New Economy. Halifax: Fernwood.

Hursh, D. (2007). Exacerbating Inequality: The Failed Promise of the No Child Left Behind Act. Race, Ethnicity and Education, 10 (3), 295-308.

Hurst, M. (2011). Debt and Family Type in Canada. Statistics Canada, Catalogue no. 11-008-X

Hussan, S.K., and M. Scott. (2009). Jason Kenney's Doublespeak Exposed: Tories Unleash Canada Service Border Services on Migrants. The Bullet. http://www.socialistproject.ca/bullet/bullet207.html

Hussey, I. and P. Leclerc. (2011). The Big Smoke" Screen: Toronto's G20 Protests, Police Brutality, and the Unaccountability of Public Officials. Socialist Studies, 7(1/2), 282-302.

Huws, U. (2003). The Cybertariat: Virtual Work in a Real World. New York: Monthly Review Press.

Hyslop-Margison, E.J. (2012). Post Neo-Liberalism and the Humanities: What the Repressive State Apparatus Means for Universities. Canadian Journal of Higher Education, 42(2), $1-12$.

Iacovetta, F. (1992). Such Hardworking People: Italian Immigrants in Postwar Toronto. Montreal and Kingston: McGill-Queens University Press. 
Ibbitson, J. (2001). Loyal No More: Ontario's Struggle for a Separate Destiny. Toronto: HarperCollins.

IBIKETO. (2010). Rob Ford's Campaign Platform.

http://www.ibiketo.ca/sites/default/files/Rob\%2520Ford\%2520Campaign\%2520Platform $\% 25200 c t 2010 . p d f$

Innis, H. The Fur Trade In Canada. Toronto: University of Toronto Press.

International Monetary Fund. (2011). World Economic Outlook: Slowing Growth, Rising Risks. http://www.imf.org/external/pubs/ft/weo/2011/02/pdf/text.pdf

Inwood, G.J. (2000). Federalism, Globalization and the (Anti-)Social Union. In M. Burke, C.

Mooers and J. Shields (Eds.), Restructuring and Resistance: Canadian Public Policy in an Age of Global Capitalism (pp. 124-144). Halifax: Fernwood Publishing.

Isin, E.F. and J. Wolfson. (1999). The Making of the Toronto Megacity: An Introduction. Working Paper, no.21. Toronto: Urban Studies Programme, York University.

Jackson, A. (2005). Work and Labour in Canada: Critical Issues. Toronto: Canadian Scholars' Press.

---- (1999). Free Trade A Decade Later. Studies in Political Economy, 58, 141-160.

Jackson, A. and S. Schetagne. (2003). Solidarity Forever? An Analysis of Changes in Union Density. Just Labour: A Canadian Journal of Work and Society, 4, 53-82

James, R. (2011, November 4). Fact and Fiction in City Finances. Toronto Star [online]. http://www.thestar.com/news/article/1081654--james-fact-and-fiction-in-city- finances

--- (2011b, July 12). Rob Ford's Gravy Train Running on Fumes. Toronto Star. http://www.thestar.com/mobile/NEWS/article/1023260 
(2011, September 28). Best Budget Fix Mixes Fees, tax cuts. Toronto Star. http://www.thestar.com/news/gta/2011/09/28/james_best_budget_fix_mixes_fees_tax_cu ts.html

Jenson, J. (1986). Gender and Reproduction: Or, Babies and the State. Studies in Political Economy, 20, 9-46.

Jenson, J. and M. Sineau. (2001). Who Cares? Women's Work, Child Care, and Welfare State Redesign. Toronto: University of Toronto Press.

Jenson, Jane, Rianne Mahon, and Susan D. Phillips. "No Minor Matter: The Political Economy of Childcare in Canada." In Clement, W. and L. Vosko (Eds.), Changing Canada: Political Economy as Transformation (pp.135-60). Montreal and Kingston: McGill-Queen's University Press, 2003.

Jessop, B. (1990). State Theory: Putting Capitalist States in their Place. Pennsylvania: Pennsylvania State University Press.

----- (1993). Towards a Schumpeterian Workfare State? Preliminary Remarks on Post-Fordist Political Economy. Studies in Political Economy 40, 7-39.

Johnson, R., and R. Mahon. (2005). NAFTA: The Redesign and Rescaling of Canada's Welfare State. Studies in Political Economy, 76, 7-30.

Johnson, W. (2005). Stephen Harper and the Future of Canada. Toronto: McClelland and Stewart.

Jones, G.A. and S.J. Young. (2004). 'Madly Off in All Directions': Higher Education, Marketization and Canadian Federalism. In Texeira, P., B. Jongbloed, D. Dill and A. Amaral (Eds.), Markets in Higher Education: Rhetoric or Reality? (pp.185-206).

Dordrecht, Netherlands: Kluwer Academic Publishers. 
Kane, L. (2011, June 15). Feds table legislation to end Air Canada strike. Vancouver Sun. http://www.vancouversun.com/business/Feds+table+legislation+Canada+strike/4 948582/story.html

Kaplan, G. (2010, October 8). The Hidden History of Bob Rae's Government in Ontario. Globe and Mail. http://www.theglobeandmail.com/news/politics/the-hidden-history-of-bob-raesgovernment-in-ontario/article1749515/.

Kautsky, J.H. (2002). Social Democracy and the Aristocracy. New Brunswick, New Jersey: Transaction Publishers.

Kealey, G.S. (1995). Workers and Canadian History. Montreal: McGill-Queens Press.

Keil, R. (2002). "Common-Sense" Neoliberalism: Progressive Conservatism in Toronto, Canada. Antipode, 34 (3), 578-601.

(1998). Toronto in the 1990s. Dissociated Governance? Studies in Political Economy, 56, $151-167$ (2000). Third Way Urbanism: Opportunity or Dead-End? Alternatives, 25, 247-267

Keown, L.A. (2011). The Financial Knowledge of Canadians. Statistics Canada, Catalogue no. 11-008.

Keung, N. (2010, August 3). Employment Bill Stymies Complaints Against Employers, Critics Say. Toronto Star. http://www.thestar.com/news/ontario/article/843099--employment-billstymies-complaints-against-employers-critics-say.

Keynes, J.M. (1936). The General Theory of Employment, Interest and Money. London: Macmillan.

Kimeldorf, H. (1999). Battling for American Labor: Wobblies, Craft Workers and the Making of the Union Movement: Berkeley and Los Angeles: University of California Press. 
King. W.L.M. (1918). Industry and Humanity: A Study in the Principles Underlying Industrial Reconstruction. Toronto: University of Toronto Press.

Kipfer, S. (2007). Mayor Miller and Toronto's Suburbs: Colonization and Competition. New Socialist, 60, 28-29.

Kipfer, S. and R. Keil. (2002). Toronto Inc? Planning the Competitive City in the New Toronto. Antipode, 34 (2), 227-264.

Kipfer, S. and J. Petrunia. (2009). "Recolonization" and Public Housing: A Toronto Case. Studies in Political Economy, 83, 111-139

Klassen, T.R. and D. Buchanan. (1997). Getting it Backward: Economy and Welfare from 1985 to 1995. Canadian Public Policy, 23(3), 333-338.

Kohler, N. (2010). How Rob Ford Won Toronto. Macleans. http://www2.macleans.ca/2010/10/29/the-game-changer/

Kohler, N. (2010b). The Political Genius of Rob Ford. Macleans. http://www2.macleans.ca/2010/10/12/the-political-genius-of-rob-ford/

Kolasky, J. (1990). Prophets \& Proletarians: Documents on the Rise and Decline of Ukrainian Communism in Canada. Edmonton: Canadian Institute of Ukrainian Studies Press.

Kolasky, J. (1990). Prophets \& Proletarians: Documents on the Rise and Decline of Ukrainian Communism in Canada. Edmonton: Canadian Institute of Ukrainian Studies Press.

Kozolanka, K. (2007). The Power of Persuasion: The Politics of the New Right in Ontario. Montreal: Black Rose Books.

KPMG. (2009). Tough Choices Ahead: The Future of the Public Sector. http://www.kpmg.com/Global/en/IssuesAndInsights/ArticlesPublications/Documents/Tough -choices-ahead.pdf 
Krahn, H.J. and G.S. Lowe. (2002). Work, Industry and Canadian Society, fifth edition. Toronto: Thomson-Nelson.

Kumar, P. and C. Schenk (Eds.). (2006). Paths to Union Renewal: Canadian Experiences Peterborough, ON: Broadview Press.

Lacher, H. (1999). Embedded Liberalism, Disembedded Markets: Reconceptualising the Pax Americana. New Political Economy, 4(3), 343-360.

Lahey, K. (2009). Gender Analysis of 2009. Progressive Economics Forum. http://www.progressiveeconomics.ca/2009/01/31/gender-analysis-of-budget-2009/

Langille, D. (1987). The Business Council on National Issues. Studies in Political Economy, 24, 41-85.

Lapides, K (Ed.). (1987). Marx and Engels on the Trade Unions. New York: Praeger.

Lauren, A. and W. Robson. (2011). Ottawa's Pension Gap: The Growing and Under-Reported Cost of Federal Employee Pension. C.D Howe Institute. http://www.cdhowe.org/pdf/ebrief_127.pdf

Laxer, J. (1975). Canada's Energy Crisis. Toronto: James Lorimer and Company.

--- (2009). Beyond the Bubble: Imagining a New Canadian Economy. Toronto: Between the Lines Press.

Laxer, R.M. (Eds.). (1973). Canada Ltd.: The Political Economy of Dependence. Toronto: McClelland and Stewart.

Laycock, D. (2002). The New Right and Democracy in Canada: Understanding Reform and Canadian Alliance. Toronto: Oxford University Press.

Leach, B.(2002). Class, Discipline and the Politics of Opposition in Ontario. In Lem, W. and B. Leach (Eds.), Culture, Economy, Power: Anthropology as Critique, Anthropology as Praxis, (pp.191-205). New York: State University of New York Press. 
Lebowitz, M. (2003). Beyond Capital: Marx's Political Economy of the Working Class, 2nd edition. Hampshire, England: Palgrave Macmillan.

Lemon, J. (1985). Toronto Since 1918. Toronto: James Lorimer Press.

Levitt, K. (2002). Silent Surrender: The Multinational Corporation in Canada. Montreal and Kingston: McGill-Queens University Press.

Levin, J.S., S. Kater and R.L. Wagoner. (2006). Community College Faculty: At Work in the New Economy. New York: Palgrave Macmillan.

Levy, S. (2009, June 30). Trash Talk Was Easy in '02. Toronto Sun.

http://www.torontosun.com/comment/columnists/sueann_levy/2009/06/30/9977911sun.html

-...- (2011, May 15). Trash Plan a Slam Dunk. Toronto Sun. http://www.torontosun.com/2011/05/13/levy-trash-plan-a-slam-dunk

Lewchuk, W. M. Clarke and A. De Wolff. (2011). Working Without Commitments: The Health Effects of Precarious Employment. Montreal and Kingston: McGill-Queen Press.

Levitz, S. (2011, March 26). Harper Dogged By 2004 Coalition Letter. iPolitics. http://www.ipolitics.ca/2011/03/26/harp-sang-different-tune-on-coalition-in-2004/

Lipietz, A. (1987). Mirages and Miracles: The Crisis in Global Fordism. New York: Verso.

Lipton, C. (1967). The Trade Union Movement in Canada, 1927-1959. Toronto: NC Press.

Little, W. (1969). Collective Bargaining in the Ontario Government Service: A Report of the Special Advisor, His Honour Judge Walter Little. Ontario: Queens Park Printers.

Livesey, B. (2012). Thieves of Bay Street: How Banks, Brokerages and the Wealthy Steal Billions From Canadians. Toronto: Random House.

Livingstone, D.W. and A. Scholtz. (2007). Contradictions of Labour Processes and Workers' Use of Skills In Advanced Capitalist Economies. In Shalla, V. and W. Clement (Eds.), 
Work In Tumultuous Times (pp.131-162). Montreal and Kingston: McGill-Queens

University Press.

Livingstone, D.W., D.E. Smith and W. Smith. (2011). Manufacturing Meltdown: Reshaping

Steel Work. Halifax: Fernwood Publishing.

Lorinc, J. (2010). How George Smitherman's Dead-End Run for Toronto Mayor Went Wrong.

Globe \& Mail. http://www.theglobeandmail.com/news/toronto/city-votes/city-votes-

news/how-george-smithermans-dead-end-run-for-toronto-mayor-went-

wrong/article1775761/

Loxley, J. (2010). Public Service Private Profits: The Political Economy of Public-Private

Partnerships in Canada. Halifax, Nova Scotia: Fernwood Publishing.

Lu, V. (2011, October 26). Air Canada Withdraws Pension Challenge. Toronto Star.

http://www.thestar.com/business/article/1076037--air-canada-withdraws-pension- challenge

Lynd, S. (2001). Local Unions, "Primitive Democracy," and Workers' Self-Activity.

WorkingUSA, 4(4), 49-58.

MacDermid, R. and G. Albo. (2001). Divided Province, Growing Protests: Ontario Moves Right.

In K. Brownsey and M. Howlett (Eds.), The Provincial State in Canada: Politics in the

Provinces and Territories (pp.441-447). Toronto: Broadview Press.

Macdonald, D. (2010). Canada's Housing Bubble: An Accident Waiting to Happen. Ottawa:

Canadian Centre for Policy Alternatives.

----- (2011). Corporate Income Taxes, Profit and Employment Performance of Canada's Largest

Corporations. Ottawa: Canadian Centre for Policy Alternatives

(2012). The Big Banks' Big Secret: Estimating Government Support for Canadian Banks

During the Financial Crisis. Ottawa: Canadian Centre for Policy Alternatives. 
Mackenzie, H. (2010). Recession-Proof: Canada's 100 Best Paid CEO's. Ottawa: Canadian

Centre for Policy Alternatives.

--.- (2011). Platform Costing and the Politics of Fiscal Policy in Ontario. Ottawa: Canadian

Centre for Policy Alternatives.

----- (2012). Ontario's Fiscal Reality: Cup Half Empty or Half Full? Ottawa: Canadian Centre for Policy Alternatives.

----- and R. Shillington. (2009). Canada's Quiet Bargain: The Benefits of Public Spending. Ottawa: Canadian Centre for Policy Alternatives.

Mackeral, K. (2011, October 14). CAW Throws Support Behind Growing Occupy Movement. Globe \& Mail. http://www.theglobeandmail.com/news/national/caw-throwssupport-behind-growing-occupy-movement/article2201340/

Mackintosh, W.A. (1923). Economic Factors in Canadian History. Canadian Historical Review, $4(1), 12-25$.

MacLellan, D. (2009). Neoliberalism and Ontario Teachers' Unions: A "Not-So" Common Sense Revolution. Socialist Studies, 5(1), 51-74

Mallet, T and Q. Wong. (2008). Wage Watch: A Comparison of Public-Sector and Private-Sector Wages. Canadian Federation of Independent Business. http://www.cfib-fcei.ca/cfibdocuments/rr3077.pdf

Maloney, P. (2011b, October 11). City Headed Toward $\$ 140$ Million Thanks to Tax Ford Wants to Scrap. Toronto Star. http://www.thestar.com/news/article/1067830--cityheaded-for-140m-surplus-thanks-to-tax-ford-wants-to-scrap (2011, July 17). City Budget Gap Exaggerated, Critics Say. Toronto Star. http://www.thestar.com/news/article/1026208--city-budget-gap-exaggerated-critics-say 
McCarthy, L., S. Sanger., J. Stanford., E. Weir. (24, August 2010). Ontario's Public-Sector Compensation Freeze: A Critical Appraisal. Public Service Alliance of Canada, Canadian Union of Public Employees, Canadian Auto Workers, and United Steelworkers.

Mann, M. (1973). Consciousness and Action Among the Western Working Class. London: Macmillan.

Marcuse, P. (2009). From Critical Urban Theory to the Right to the City. City, 13 (2/3), 185-197 Marsh, J. (2011). Class Dismissed: Why We Cannot Teach or Learn Our Way Out of Inequality. New York: Monthly Review.

Marshall, K. (2011). Generational Change in Paid and Unpaid Work. Statistics Canada, Catalogue no. 11-008-X

Martin, L. (2010). Harperland: The Politics of Control. Toronto: Penguin.

Marx, K. (1847). The Free Trade Congress at Brussels. http://www.marxists.org/archive/marx/works/1847/09/30.htm (1847). The Poverty of Philosophy.

http://www.marxists.org/archive/marx/works/subject/hist-mat/pov-phil/ch02.htm (1866). The Different Questions.

http://www.marxists.org/archive/marx/iwma/documents/1866/instructions.htm\#06 (1871). R. Landor, Interview with Karl Marx.

http://www.marxists.org/archive/marx/bio/media/marx/71_07_18.htm

---- (1875). Critique of the Gotha Programme.

http://www.marxists.org/archive/marx/works/1875/gotha/

--- (1990). Capital. Vo.1. London: Penguin.

-.--- (2009). The Civil War in France. London: Verso.

Marx K. and F. Engels. (1879). Letter to the SPD Leadership: Strategy and Tactics of the Class 
Struggle. http://www.marxists.org/archive/marx/works/1879/09/17.htm

--- (2002). The Communist Manifesto. London: Penguin.

Matthews, R. and J.A. Steele. (1969). The Struggle for Canadian Universities: A Dossier. Toronto: New Press.

Matthieu, E. (2010, December 14). Canadian's Spending Far Beyond Means. Toronto Star. http://www.thestar.com/article/906396--alarm-raised-as-household-debt-spikes.

Mattick, P. (1969). Marx and Keynes: The Limits of the Mixed Economy. Boston: Porter Sergeant. McArthur, G. (2011, February 14). "Ontarians Turning Against McGuinty, Poll Finds." Globe and Mail. http:/www.theglobeandmail.com/news/national/ontario/poll-finds-ontarians-turning\%09against-mcguinty/article $1905696 /$ cmpid=rss 1 .

McBride, S. (2001). Paradigm Shift: Globalization and the Canadian State. Halifax: Fernwood.

McBride, S. and J. Shields. (1997). Dismantling a Nation: The Transition to Corporate Rule in Canada, second edition. Halifax: Fernwood Publishing.

McBride, S. and H. Whiteside. (2011). Public Austerity, Private Affluence: Economic Crisis and Democratic Malaise in Canada. Halifax: Fernwood.

McChesney, R.W. (2008). The Political Economy of the Media: Enduring Issues, Emerging Dilemmas. New York: Monthly Review Press.

McKeen, W. and A. Porter. (2003). Politics and Transformation: Welfare State Restructuring in Canada. In Clement, W. and L. Vosko (Eds.), Changing Canada: Political Economy as Transformation (pp. 109-134). Montreal \& Kingston: McGill-Queen's University Press. McNally, D. (2009). Inequality, The Profit-System and the Global Crisis. In Guard, J. \& W. Antony (Eds.), Bankruptcies \& Bailouts (pp. 32-42). Halifax: Fernwood.

---- (2010). Global Slump: The Politics and Economics of Resistance. Oakland: PM Press. 
McQuiag, L. (1991). The Quick and the Dead: Brian Mulroney, Big Business and the Seduction of Canada. Toronto: Viking.

McQuiag, L. and N. Brooks. (2011). The Trouble With Billionaires. Toronto: Penguin.

Menger, K. (1883/1985). Investigations Into the Method of the Social Sciences with Special Reference to Economics. New York: New York University Press.

Merriam-Webster. (2010). Word of the Year 2010. http://www.merriamwebster.com/info/10words.htm

Mieksins, P. (1986). Beyond the Boundary Question. New Left Review, 157, 101-120.

Milonakis, D. and B. Fine. (2009). From Political Economy to Economics: Method, the Social and Historical in the Evolution of Economic Theory. New York: Routledge.

Ministry of Training, Colleges and Universities. (2012). Strengthening Ontario's Centre's of Creativity, Innovation and Knowledge.

http://www.tcu.gov.on.ca/pepg/publications/DiscussionStrengtheningOntarioPSE.pdf

Mirowski, P. and D. Plehwe, eds. (2009). The Road to Mont Pelerin: The Making of the Neoliberal Thought Collective. Cambridge: Harvard University Press.

Mitchell, D. (2003). The Right to the City: Social Justice and the Fight for Public Space. New York: Guilford Publications.

Montebraaten, L. (2011, March 22). 400,000 Rely on Food Banks Each Month in Ontario. Toronto Star. http://www.thestar.com/news/article/957658--400-000-rely-on-food-banks-eachmonth-inontario

Moody, K. (1988). An Injury to All: The Decline of American Unionism. New York: Verso. Murphy, J. \& Godfrey, T. (2011, June 16). Air Canada Workers Back at Work. http://cnews.canoe.ca/CNEWS/Canada/2011/06/13/18277961.html 
Naczk, K. (2007). Employment Trends in the Federal Public Service. Statistics Canada, Catalogue no. 11-621-MIE - 53.

Nadeau, C. (2011). Rogue in Power: Why Stephen Harper is Remaking Canada by Stealth. Toronto: James Lorimer \& Company.

Naiman, Joanne. How Societies Work: Class, Power and Change in a Canadian Context. $4^{\text {th }}$ Edition. Black Point, NS: Fernwood, 2008.

Naumetz, T. (2012, September 13). AG's spring report on feds' F-35 fighter jets attracted 'massive' media attention: documents. The Hill Times. http://www.hilltimes.com/news/politics/2012/09/13/ag\%E2\%80\%99s-spring-report-onfeds $\% E 2 \% 80 \% 99-f-35$-fighter-jets-attracted-\%E2\%80\%98massive $\% E 2 \% 80 \% 99 / 32104$

Newstadt, E. (2008). The Neoliberal University: Looking at the York Strike. The Bullet. http://www.socialistproject.ca/bullet/bullet165.html

Noonen, J. (2009). The Windsor CUPE Strike: Implications for the Labour Movement and the Left. The Bullet. http://www.socialistproject.ca/bullet/bullet236.html

----- (2012). Academic Freedom Endangered in Ontario. Canadian Centre for Policy Alternatives: The Monitor. http://www.policyalternatives.ca/publications/monitor/academic-freedomendangered-ontario

National Union of Public General Employees. (2010, February 24). Stephen Harper's Record of Denying Democracy. http://www.nupge.ca/content/stephen-harper-s-record-denyingdemocracy

One Toronto. (n.d.). KPMG Report Summary. http://onetoronto.ca/section/18 Ontario Confederation of University Faculty Associations. (2012). Growing Ontario's Universities For the Future. http://ocufa.on.ca/wordpress/assets/OCUFA-Submission-MTCUConsultation-2012-FINAL.pdf 
Ontario Committee on Government Productivity. (1972). Report to the Executive Council of the Government of Ontario. Toronto: Queen's Printer.

Ontario Confederation of University Faculty. (2012). OCUFA Analysis of the Drummond Report:

Long on cuts, short on insight. http://utlibrarians.files.wordpress.com/2012/02/ocufadrummond-report-analysis-feb-22-2012-final.pdf

Ontario Ministry of Economic Development and Trade. (2011). Ontario-Quebec Trade and Cooperation Agreement.

http://www.ontariocanada.com/ontcan/1medt/en/about_spotlight_en.jsp

---- (2010). Open For Business. http:/www.ontariocanada.com/ontcan/1 medt/en/ofb_main_en.jsp

Ontario Ministry of Finance. (2010a). Ontario's Long-Term Report on the Economy.

http://www.fin.gov.on.ca/en/economy/ltr/2010/ltr2010.pdf

---- (2010b). Backgrounder: Ontario's Tax Plan For Jobs and Growth.

http://www.fin.gov.on.ca/en/budget/ontariobudgets/2010/bk_tax.pdf.

----- (2011). FAQ: Public Sector Compensation Restraint.

http://www.fin.gov.on.ca/en/budget/ontariobudgets/2010/faq july.html.

--- (2010a). Ontario's Long-Term Report on the Economy.

http://www.fin.gov.on.ca/en/economy/ltr/2010/ltr2010.pdf.

----- (2010b). Public Sector Salary Disclosure 2010.

http://www.fin.gov.on.ca/en/publications/salarydisclosure/2010/

Ontario Ministry of Labour. (2010d). Employment Standards Task Force.

http://www.labour.gov.on.ca/english/news/bulletin_ofba.php.

---- (2010c, October 25). New Legislation Modernizes Ontario's Employment Standards.

http://www.labour.gov.on.ca/english/news/bulletin_ofba.php 
Ontario Public Service Employees Union. (n.d.). Questions and Answers about the Ontario government's wage freeze plan for public sector workers. http://www.opseu.org/campaign/stopthewagefreeze/qanda.htm

Organization for Economic Cooperation and Development. (2011). Revenue Statistics: 19652010. ISBN: 978-92-64-12286-4

Osberg, L. (2012). Instability Implications of Increasing Inequality: What Can be Learned From North America. Ottawa: Canadian Centre for Policy Alternatives.

Paap, K. (2006). Working Construction: Why White Working-Class Men Put Themselves And the Labor Movement in Harm's Way. Ithaca: Cornell University Press.

Palley, I.T. (2005). From Keynesianism to Neoliberalism: Shifting Paradigms in Economics. In Saad-Filho, A. and D Johnston (Eds.), Neoliberalism: A Critical Reader, (pp.20-30). London: Pluto Press.

Palmer, B.D. (1985). “Taking It": Ontario Workers' Struggles. In W.J.C. Cherwinki and G.S. Kealey (Eds.), Lectures in Canadian Labour and Working-Class History (pp.183-198). St John's, Newfoundland: Committee on Canadian Labour.

---- (1992). Working-Class Experience: Rethinking the History of Canadian Labour, 18001991. Toronto: McClelland and Stewart.

--- (2003). What's Law Got to Do With It? Historical Considerations on Class Struggle, Boundaries of Constraint, and Capitalist Authority. Osgoode Hall Law Journal, 41(2/3), 465-489.

Panitch, L. (1977). The Role and Nature of the Canadian State. In L. Panitch (Ed.), The Canadian State: Political Economy and Political Power (pp.3-27). Toronto: University of Toronto Press. 
----- (2008). Renewing Socialism: Democracy, Strategy, and Imagination. London: Merlin Press.

Panitch, L. \& D. Swartz. (2003). From Consent to Coercion: The Assault on Trade Union Freedoms. Aurora, ON: Garamond Press.

Panitch, L. and S. Gindin. (2004). Global Capitalism and American Empire. Halifax, Nova Scotia: Fernwood Publishing.

Panitch, L. and S. Gindin. (2012). The Making of Global Capitalism: The Political Economy of American Empire. London: Verso.

Panitch, L., G. Albo and V. Chibber (Eds.). (2010). The Crisis This Time, Socialist Register. London: Merlin Press.

Parr, J (Ed.). (1985). A Diversity of Women: Ontario, 1945-1980. Toronto: University of Toronto. Parrot, J.C. (2005). My Union, My Life: Jean-Claude Parrot and the Canadian Union of Postal Workers. Halifax: Fernwood.

Peat, D. (2011, November 8). City Union Vows to Protect 'Jobs For Life'. Toronto Sun. http://www.torontosun.com/2011/11/08/city-union-vows-to-protect-jobs-for-life Peck, J. (2008). Remaking Laissez-Faire. Progress in Human Geography, 32(1), 3-43.

----- (2005). Struggling with the Creative Class. International Journal of Urban and Regional Research, 29(4), 740-770.

----- (2003). The Rise of the Workfare State. Kurswechsel, 3, 75-87.

---- (2010). Constructions of Neoliberal Reason. Oxford: Oxford University Press.

---- (2001). Workfare States. New York \& London: The Guilford Press

Peck, J. and A. Tickell. (2002). Neoliberalizing Space. Antipode, 34(3), 380-404. 
Peck, J. and N. Theodore. (2010). Labor Markets from the Bottom Up. In McGrath-Champ, S., A. Herod, and A. Rainnie (Eds.) Handbook of Employment and Society: Working Space (pp.87105). Northampton, MA: Elgar.

Penner, N. (1988). Canadian Communism: The Stalin Years and Beyond. Toronto: Methuen.

----- (1992). From Protest to Power: Social Democracy in Canada, 1900-Present. Toronto: James Lorimer and Company.

Perelman, M. (2000). The Invention of Capitalism: Classical Political Economy and the Secret History of Primitive Accumulation. Durham: Duke University Press.

----- (2011). The Invisible Handcuffs of Capitalism: How Market Tyranny Stifles the Economy by Stunting Workers. New York: Monthly Review Press.

Pierson, R.R. and M.G. Cohen. (1995). Women's Issues, Volume II: Bold Visions, Twenty-Five Years of Women's Activism in English Canada. Toronto: James Lorimer and Company. Pilon, D., S. Ross and L. Savage. (2011). Solidarity Revisited: Organized Labour and the New Democratic Party. Canadian Political Science Review, 5(1), 20-37.

Polanyi, K. (1944). The Great Transformation. Boston, Massachusetts: Beacon Press.

Preville, P. (2009). Toronto Life: The Good News About the Bad Economic Times. http://www.torontolife.com/features/good-news-about-bad-times/?pageno=1

Przeworski, A. (1985). Capitalism and Social Democracy. Cambridge: Cambridge University Press. PSAC. (2009a, August 21). Museum workers deserve respect on the job. http://www.psac.com/news/2009/bargaining/20090821-e.shtml.

-.-- (2009b, October 10). Update for Striking Museum Workers Concerning Unusual Correspondence from CMCC. http://psac.com/news/2009/bargaining/20091010-e.shtml 
(2009c, November 9). Striking Museum Workers to Throw Picket Line Tea Party in

Honour of Prince Charles. http://www.psac-afpc.com/news/2009/releases/72-1109-

e.shtml

----- (2009d, December 11). Rally and concert to support striking museum workers.

http://www.psac-afpc.com/news/2009/releases/84-1209-e.shtml

-.--- (2009e, December 15). Museum strike is over. http://www.psac-

afpc.com/news/2009/releases/87-1209-e.shtml

----- (2009f, November 26). Negotiated settlement impossible Museum reject final offer.

http://www.psac-afpc.org/news/2009/releases/77-1109-e.shtml

-.--- (2009g, December 2). Why We Voted No.

http://www.psac-afpc.org/documents/bargaining/why_we_voted_no-e.pdf

-..-- (2009h, December 4). Personal Correspondence: PSAC Bargaining Committee.

---- (2011, June 15). PSAC members show support for their negotiating team at the National

Gallery of Canada.

http://www.psac-afpc.org/news/2011/bargaining/20110615-e.shtml

----- (2010). Seven Myths About Public Service Pensions.

http://www.psac-afpc.org/petition-pension/mythes-e.asp

---- (2010). Our Union Voice. http://www.psac-

afpc.com/news/publications/unionvoice/spring_printemps2010-e.shtml\#3

Pulkingham, J. and G. Ternowetsky, (Eds.). (1997). Remaking Canadian Social Policy: Social

Security in the late 1990s. Halifax: Fernwood Publishing.

Pupo, N. (1997). Always Working, Never Done: The Expansion of the Double Day. In A.

Duffy, D. Glenday and N.Pupo (Eds.), Good Jobs, Bad Jobs, No Jobs: The

Transformation of Work in the 21st Century (pp. 144-165). Toronto: Harcourt 


\section{Brace \& Company}

Pupo, N. and A. Duffy. (2007). Blurring the Distinction Between Public and Private Spheres:

The Commodification of Household Work - Gender, Class, Community and Global

Dimensions. In Shalla, V. and W. Clement (Eds.), Work In Tumultuous Times (pp.289-

325). Montreal and Kingston: McGill-Queens University Press.

Pupo, N. and A. Noack. (2010). Dialing for Service: Transforming the Public-Sector Workplace in Canada. In Pupo, N. and M. Thomas (Eds.), Interrogating the New Economy: Restructuring Work in the 21st Century (pp.111-128). Toronto: University of Toronto Press.

Pupo, N. and M. Thomas (Eds.). (2010). Interrogating the New Economy: Restructuring Work in the 21st Century. Toronto: University of Toronto Press.

Quebec-Ontario Trade and Cooperation Agreement. (2009) http://www.mdeie.gouv.qc.ca/fileadmin/sites/internet/documents/publications/pdf/Exporatio n/accords/signature_quebec_ontario_trade.pdf.

Rae, M. (2010). Kierkegaard and Theology. New York: Continuum Books.

Ralph, D., A. Regimbald and N. St.Amand (Eds.). Open For Business, Closed to People: Mike Harris 's Ontario. Halifax, Nova Scotia: Fernwood Publishing.

Rattner, S. (1979, October 18). Volcker Asserts U.S. Must Trim Living Standards. New York Times.

Rea, K.J. (1985). The Prosperous Years: The Economic History of Ontario, 1939-1975. Toronto: University of Toronto Press.

Red Tape Review Commission. (1997). Cutting the Red Tape and Barriers to Jobs and Better Government. Toronto: Queens Press Printer.

McKeough, A. and B Henderson. (1975). Report of the Special Program Review. Toronto: Queen's Printer. 
Reshef, Y. and S. Rastin. (2003). Unions in the Time of Revolution: Government Restructuring in Alberta and Ontario. Toronto: University of Toronto Press.

Rider. D. (2011a, March 19). Team Ford Set to Give Go-Ahead to Gravy-Sniffing Consultants. Toronto Star. http://www.thestar.com/news/article/956831--team-ford-set- toapprove-hiring-of-gravy-sniffing-consultants

---- (2011b, September 14). Ford Support Plummeting, Poll Suggests. Toronto Star. http://www.thestar.com/news/article/1053210--ford-support-plummeting-pollsuggests? $\mathrm{bn}=1$

----- (2011 c, July 16). City Moves to Outsource Police Station Cleaners. Toronto Star. http://www.thestar.com/news/torontocouncil/article/1010257--city-moves-to-outsourcepolice-station-cleaners

---- (2010b, October 8). Ford Fiscal Plan Big On Numbers, Short on Details. Toronto Star. http://www.thestar.com/news/article/872691--rob-ford-unveils-his- fiscal-plan-promisingbig-savings-for-toronto

----. (2010, April 16). Ford Surges Into Second Place in Mayoral Race. Toronto Star. http://www.thestar.com/yourtoronto/yourcitymycity/2010/04/16/ford_surges_into_second _place_in_ma yoral_poll.html

Ridler, M. and P. Maloney. (2011, May 17). Toronto Votes to Contract Out Garbage Pick Up. Toronto Star. http://www.thestar.com/news/gta/2011/05/17/toronto_votes_to_contract_out_garbage_pi ckup.html (2011, July 12). City Consultant Finds Little Fat in Public Works. Toronto Star. http://www.thestar.com/news/torontocouncil/article/1023019--city-s-consultant-findslittle-fat-in-public-works 
Ridler, D. and D. Dale (2011, September 14). Ford Dismisses Bad Poll Results, Says He'll 'Stay the Course.' Toronto Star. http://www.thestar.com/news/article/1053640--forddismisses-bad-poll-results-says-he-ll-stay-the-course

Rinehart, J. (2006). The Tyranny of Work: Alienation and the Labour Process. Toronto: Thomson Nelson.

Roberts, H. (2010, October 28). Unions Talk to Students About Possible Strike. The Charlatan. http://www.charlatan.ca/content/unions-speak-students-about-possible-strike Roberts, W. (1994). Don't Call Me Servant: Government Work and Union in Ontario, 19111984. Toronto: Ontario Public Service.

Roediger, D.R. (2005). Working Toward Whiteness: How America's Immigrants Became White. Cambridge, Massachusetts: Basic Books.

Rogers, G. and J. Rogers (Eds.). (1989). Precarious Jobs in Labour Market Regulation: The Growth of Atypical Employment in Western Europe. Belgium: International Institute For Labour Studies.

Rosen \& Associates. (2011). The City of Toronto's Proposal to Contract Out Certain Waste Collection Services. http://local416.com/images/stories/tceu\%20report002.pdf

Rosenfeld, H. and C. Fanelli. (2010). A New Type of Political Organization: The Greater Toronto Workers Assembly. MRzine: A project of the Monthly Review Foundation. http://mrzine.monthlyreview.org/2010/rf050810.html

Ross, S. (2005). The Making of CUPE: Structure, Democracy and Class Formation. Unpublished doctoral dissertation. York University, Toronto, ON. (2007). Varieties of Social Unionism: Towards a Framework for Comparison. Just Labour, $11,16-34$. 
--- (2008). Social Unionism and Membership Participation: What Role for Union

Democracy? Studies in Political Economy, 81, 129-157.

Rowell, N.W. and J. Sirois. (1940). Report of the Royal Commission on Dominion-Provincial Relations. Ottawa: Kings Printer.

Rubin, B. (2005). Contradictions of Commitment in the New Economy: Insecurity, Time and Technology. Social Science Research, 34(4), 843-861.

Russell, B. (2000). From the Workhouse to Workfare: The Welfare State and Shifting Policy Terrains. In Burke, M., C. Mooers and J. Shields (Eds.), Restructuring and Resistance: Canadian Public Policy in an Age of Global Capitalism (pp. 26-49). Halifax: Fernwood Publishing.

Saad-Filho, A. \& D. Johnston (Eds.). (2005). Neoliberalism: A Critical Reader. London: Pluto Press.

Saberi, P and S. Kipfer. (2010). Rob Ford in Toronto: Why the Ascendancy of Hard-Right Populaism in the 2010 Mayoral Election? New Socialist Webzine. http://www.newsocialist.org/index.php?view=article\&catid=51\%3Aanalysis\&id= 314\%3Arob-ford-in-toronto-why-the-ascendancy-of-hard-right-populism-in-the- 2010mayoral-election\&format $=$ pdf\&option $=$ com_content\&Itemid $=98$

Sanger, T. (2011). Fair Shares: How Banks, Brokers and the Financial Industry Can Pay Fairer Taxes. Ottawa: Canadian Centre for Policy Alternatives.

Sangster, J. (1985). Doing Two Jobs: The Wage Earning Mother. In J. Parr (Ed.), A Diversity of Women: Ontario, 1945-1980 (pp.98-134). Toronto: University of Toronto Press.

------ (2010). Transforming Labour: Women and Work in Postwar Canada. Toronto: University of Toronto Press. 
Savage, L. (2008). Organized Labour and Local Politics: Ontario's 2006 Municipal Elections. Labour/Le Travail, 62, 127-140.

---- (2009). Workers' Rights as Human Rights: Organized Labor and Rights Discourse in Canada. Labor Studies Journal, 34(1), 8-20.

Savoie, J.D (Ed.). (1996). Budgeting and the Management of Public Spending. Northampton, Massachusetts: Edward Elgar.

Saywell, J.Y. (1992). Just Call Me Mitch: The Life of Mitchell F. Hepburn. Toronto: University of Toronto Press.

Scarth, T (Ed.). (2004). Hell or High Water: An Assessment of Paul Martin's Record and Implications for the Future. Ottawa: Canadian Centre fro Policy Alternatives.

Scarrow, H.A. (1957). Employer-Employee Relationships in the Civil Services of the Canadian Provinces. Public Administration, 35(1), 65-76.

Schumpeter, J. (1975). Capitalism, Socialism and Democracy. New York: Harper Collins Press. Sears, A. (1999). The 'Lean' State and Capitalist Restructuring: Towards a Theoretical Account. Studies in Political Economy, 59, 91-114.

----- (2012). Austerity in the Mind Factory. The Bullet, http://www.socialistproject.ca/bullet/610.php

Selley, C. (13 July 2011). Ford's Campaign Mantra Runs Out of Gas. National Post. http://news.nationalpost.com/2011/07/13/comment-fords-campaign-mantra-runs- out-ofgas/

Servage, L. (2009). The Scholarship of Teaching and Learning and the Neo-Liberalization of Higher Education: Constructing the "Entrepreneurial Learner." Canadian Journal of Higher Education, 39(2), 25-44. 
Shalla V. and W. Clement, (Eds.). (2007). Work In Tumultuous Times: Critical Perspectives. Montreal: McGill-Queens University Press.

Shalla, V. (2007). Shifting Temporalities: Economic Restructuring and the Politics of Working Time. In Shalla, V. and W. Clement, (Eds.), Work In Tumultuous Times (227-261). Montreal and Kingston: McGill-Queens University Press.

Shields, J. and B. Evans. (1998) Shrinking the State: Globalization and Public Administration. Halifax: Fernwood Publishing.

Siltanen, J. (2007). Social Citizenship and the Transformation of Paid Work: Reflections on Possibilities for Progressive Change. In Shalla, V. and W. Clement, (Eds.), Work In Tumultuous Times (349-379). Montreal and Kingston: McGill-Queens University Press.

Sinclair, S. (2010). Negotiating From Weakness: Canada-EU Treaty Threatens Canadian Purchasing Policies \& Public Services. Canadian Centre for Policy Alternatives. Ottawa: Canadian Centre for Policy Alternatives.

Skidelski, R. (2009). Keynes: The Return of the Master. Jackson, Tennessee: Public Affairs. Smith, C. (2009). "Fairness and Balance?": The Politics of Ontario's Labour Relations Regime, 1949-1963. Unpublished doctoral dissertation. York University, Toronto, ON.

Sorenson, C. (2012, April 23). Air Canada's Slow Dissent. Maclean's Magazine. http://www2.macleans.ca/2012/04/23/a-slow-descent/

Speech from the Throne. (2009). Canada's Economic Action Plan. Government of Canada. http://www.actionplan.gc.ca/grfx/docs/ecoplan_e.pdf

Stamp, R. (1982). The Schools of Ontario, 1876-1976. Toronto: University of Toronto Press. Standing, Guy. Global Labour Flexibility: Seeking Distributive Justice. London: MacMillan, 1999. Stanford, J. (1999). Paper Boom: Why Prosperity Requires a New Approach to the Canadian Economy. Toronto: James Lorimer and Company. 
---- (2011). Having Their Cake and Eating it Too: Business Profits, Taxes, and Investment in Canada, 1961 Through 2010. Ottawa. Canadian Centre for Policy Alternatives.

--.- (2012). Canada's Incomplete, Mediocre Recovery. Ottawa: Canadian Centre for Policy Alternatives.

Statistics Canada. (2008). University Tuition Fees. http://www.statcan.gc.ca/dailyquotidien/081009/dq081009a-eng.htm

Steele, A. (12 July 2011). Rob Ford Buys Out Toronto. Globe \& Mail. http://www.theglobeandmail.com/news/politics/second-reading/andrew-steele/robford-buys-out-toronto/article2094671/

Steinhoff, K. and G. Bickerton. (2012). The Economic Impact of the Canadian Postal Strike and Lockout: Permanent Economic Damage or Temporary Inconvenience. http://www.cupw.ca/1/4/1/8/6/index 1. shtml

Steiner, Y. (2009). The Neoliberals Confront the Trade Unions. In Mirowski, P. and D. Plehwe, (eds.), The Road to Mont Pelerin, (pp. 181-203). Cambridge: Harvard University Press.

Stevenson, G. (2009). Unfulfilled Union: Canadian Federalism and National Unity, 5th edition. Montreal and London: McGill-Queens University Press.

Stinson, J. (2010). Labour Casualization in the Public Sector. In Pupo, N. and M. Thomas (Eds.), Interrogating the New Economy: Restructuring Work in the 21st Century (pp.93110). Toronto: University of Toronto Press.

Streeck, W. and K. Thelan (Eds.). (2005). Beyond Continuity: Institutional Change in Advanced Political Economies. Oxford: Oxford University Press.

Sutherland, R. (2011). False Positive: Private Profit in Canada's Medical Laboratories. Halifax, Nova Scotia: Fernwood Publishing. 
Tait, V. (2005). Poor Workers' Unions: Rebuilding Labor From Below. Cambridge, Massachusetts: South End Press.

Tax Justice Network. (2011). The Cost of Tax Abuse: A Briefing Paper on the Cost of Tax Evasion Worldwide.

http://www.tackletaxhavens.com/Cost_of_Tax_Abuse_TJN_Research_23rd_Nov_2011.pdf Taylor, F.W. (1911). Principles of Scientific Management. New York: Harper.

TD Bank. (2007, July 17). An Update to TD Economics' 2002 Report on the Greater Toronto Area (GTA) Economy. http://www.td.com/document/PDF/economics/special/tdeconomics-special-db0707-gta.pdf

TD Economics. (2010, October 22) Toronto's Economic Recovery Leaving Many Behind. http://www.unitedwaytoronto.com/downloads/whatWeDo/reports/2010_TDEconomic_R ecovery_Report.pdf

Teelucksingh, Cheryl, and Grace-Edward Galabuzi. (2005). Working Precariously: The Impact of Race and Immigrants Status on Employment Opportunities and Outcomes. Toronto: Centre for Social Justice.

Thomas, M. (2009). Regulating Flexibility: The Political Economy of Employment Standards. Montreal \& Kingston: McGill-Queen's University Press.

Topp, B. (2010). How We Almost Gave the Tories the Boot: The Inside Story Behind the Coalition. Toronto: James Lorimer and Compnay.

Toronto and York Region Labour Council. (n.d.). Workers' Rights Campaign. http://www.labourcouncil.ca/workersrights.html Toronto Environmental Alliance (TEA). (2010). Look Before You Leap: An Environmental Perspective on Privatizing Waste Collection in Toronto. 
http://www.torontoenvironment.org/sites/tea/files/TEA\%20Report\%20-

\%20\%20Look\%20Before\%20You\%20Leap_0.pdf

Toronto Environmental Alliance/TTC Riders. (2011). Clearing the Air on the TTC.

http://www.torontoenvironment.org/campaigns/transit/clearingtheair

Toronto Star. (2011, September 17). Checking the Budget Math. Toronto Star.

http://www.thestar.com/news/article/1055500--checking-the-budget-math

---- (2011b, February 11). McGuinty Freezes Minimum Wage. Toronto Star.

http://www.thestar.com/news/ontario/article/937517--mcguinty-freezes-minimum-wage.

Toronto Star. (2008, March 2). Flaherty's 'attacks' on Ontario undermine economy: McGuinty.

Toronto Star. http://www.thestar.com/news/canada/article/308676--flaherty-s-attacks-on-

ontario-undermine-economy-mcguinty

Todd, G. (1998). Megacity: Globalization and Governance in Toronto. Studies in Political

Economy, 56, 193-216.

Trade Justice Network. (2010). Fact Sheets: Overview.

http://www.tradejustice.ca/overview?bl=y

Tufts, B. and L. Fairbanks. (2011). Pension Ponzi: How Public Sector Unions are Bankrupting

Canada's Health Care, Education and Your Retirement. Mississauga: John Wiley and Sons.

Tufts, S. (2004). Building the "Competitive City": Labour and Toronto's Bid to Host the Olympic Games. Geoforum, 35, 47-58.

Tufts, S. (2007). Emerging labour strategies in Toronto's Hotel Sector: Toward a Spatial Circuit of Union Renewal. Environment and Planning A, 39(10), 2383-2404.

Turk, J. (2000). The Corporate Campus: Commercialization and Dangers to Canada's Colleges and Universities. Toronto: James Lorimer and Company. 
Turner, L., H. C. Katz and R. W. Hurd. (2001) Rekindling the Movement: Labor's Quest for Relevance in the 21st Century. New York: Cornell University Press.

Upchurch, M., G. Taylor and A. Mathers. (2009). The Crisis of Social Democratic Trade Unionism in Western Europe: The Search for Alternatives. Surrey: Ashgate Publishing.

Uppal, S. (2011). Unionization in 2011. Statistics Canada, Catalogue no. 75-001-X

Vallancourt, J. (2010). Ontario Works, Works for Whom? An Investigation of Workfare in Ontario. Halifax: Fenrwood.

Valiani, S. (2012). Fixing the Fiscal House: Alternative Macroeconomic Solutions for Ontario. Ontario Nurses Association, http://www.ona.org/documents/File/politicalaction/ONA_FixingFiscalHouse_2012.pdf

Van Horn, R. and P. Mirowski. (2009). The Rise of the Chicago School of Economics and the Birth of Neoliberalism." In Mirowski, P. and D. Plehwe (Eds.), The Road to Mont Pelerin, (pp. 139-180). Cambridge: Harvard University Press.

Van Parjs, P. and Y. Vanderborght. (2012). Basic Income in a Globalized Economy. http://www.uclouvain.be/cps/ucl/doc/etes/documents/2012.BI_Globalization_Dublin_Ber lin.pdf

Veira, P. (2010, March 5). Budget Foreign Investment Shift 'Masterstroke'. Financial Post http://www.financialpost.com/story.html?id=2647200

Vincent, D. (2011, October 21). Toronto Community Housing Approves Sale of 706 Houses. Toronto Star. http://www.thestar.com/news/article/1074258--toronto-community-housingapproves-sale-of-706-houses

Vitullo, J. and N. Scallan (2011, October 27). CUPW, OFL Members Join Occupy Protesters in March on Bay St. Toronto Star.http://www.thestar.com/news/article/1077006--cupw-oflmembers-join-occupy-protesters-in-march-on-bay-st?bn=1 
Von Mises, L. (1944). Bureaucracy. New Haven, Connecticut: Yale University Press.

Vosko, L.F. (2000). Temporary Work: The Gendered Rise of a Precarious Employment Relationship. Toronto: University of Toronto Press.

(Ed.). (2006). Precarious Employment: Understanding Labour Market Insecurity in Canada. Montreal \& Kingston: McGill-Queen's University Press.

----- (2007). Gendered Labour Market Insecurities: Manifestations of Precarious Employment in Different Locations. In Shalla, V. and W. Clement (Eds.), Work in Tumultuous Times (pp.52-97). Montreal, QC: McGill-Queen's University Press.

Waiser, B. (2004). All Hell Can't Stop Us. The On-to-Ottawa Trek and Regina Riot. Toronto: Fitzhenry \& Whiteside.

Walchuck, B. (2011). Union Democracy and Labour Rights: A Cautionary Tale. Global Labour Journal, 2(2), 106-124.

---- (2010). Changing Union-Party Relations in Canada: The Rise of the Working Families Coalition. Labor Studies Journal, 35(1), 27-50

Walkom, T. (1994). Rae Days: The Rise and Fall of the NDP. Toronto: Key Porter.

Wallerstein, I. (2004). World-Systems Analysis: An Introduction. Durham: Duke University Press.

Warskett, R. (1997). Learning to be 'Uncivil': Class Formation and Feminization in the Public Service Alliance of Canada, 1966-1996. Unpublished doctoral dissertation. Carleton University, Ottawa, ON.

---- (2007). Remaking the Canadian Labour Movement: Transformed Work and Transformed Labour Strategies. In Shalla, V. and W. Clement (Eds.), Work in Tumultuous Times (pp.380-400). Montreal, QC: McGill-Queen's University Press. 
Watkins, M. and D.F. Forster (Eds.). Economics: Canada, Recent Readings. Toronto: McGrawHill.

Watt, D. (2010). Duncan Watt On Attracting More Grads and Paying Them Less. http://www.youtube.com/watch?v=1MF2WOkGo9Y

Well, P. (2011, May 4). The Untold Story of the 2011 Election. Macleans. http://www2.macleans.ca/2011/05/04/politics-turned-over/

Whitaker, R. (1991). Canadian Immigration Policy Since Confederation. Ottawa: Canadian Historical Association.

White, P. (2011b, July 11). Toronto to Offer New Buyout Package to Nearly All City Workers. Globe \& Mail. http://www.theglobeandmail.com/news/national/toronto/toronto-to-offer-newbuyout-package-to-nearly-all-city-workers/article2094077/

----- (2011, May 25). What Would You Cut, Toronto Asks Its Residents. Globe \& Mail. http://www.ward20.ca/news_article.php?article $=818$

White, R. (1985). Ontario: A Political and Economic History, 1600-1985. Toronto:

White, J. (1990). Mail and Female: Women and the Canadian Union of Postal Workers. Toronto: Thompson Educational Publishing.

Whitehorn, A. (1992). Canadian Socialism: Essays on the CCF-NDP. Toronto: Oxford University Press.

Whittington, L. (20, February 2010). Tories Target Civil Servants Pensions. Toronto Star. http://www.thestar.com/news/canada/article/768588--tories-target-civil-service-pensions

-.-.- (2011, January 19). Tax Cuts Drive Harper's Right-wing Agenda. Toronto Star. http://www.thestar.com/news/canada/article/924121--tax-cuts-drive-harper-s-rightwing-agenda?bn $=1$ 
Whittington, L. and S. Delacourt. (2011, January 27). Tory Tax Cuts Could Trigger Election. Toronto Star. http://www.thestar.com/news/canada/article/929037--tory-tax-cuts-couldtrigger-election.

Winfield, M.S. and G. Jenish. (1998). Ontario's Environment and the "Common Sense Revolution." Studies in Political Economy, 57, 129-145.

Winfield, M.S. (2012). Blue-Green Province: The Environment and the Political Economy of Ontario. Vancouver: University of British Columbia Press.

Wolfe, D.A. (1984). The Rise and Demise of the Keynesian Era in Canada: Economic Policy, 1930-1982. In Cross, M.S. and G.S. Kealey (Eds.), Modern Canada, 1930-1980s (pp.4678). Toronto: McClelland and Stewart.

Wood, E.M. (2002). The Origin of Capitalism: A Longer View. London: Verso.

Workman, T. (2009). If Your In My Way, I'm Walking: The Assault on Working People Since 1970. Halifax: Fernwood.

World Socialist Web Site. (2000). Union Orders Toronto City Workers To End Strike. http://www1.wsws.org/articles/2000/apr2000/tor-a1 1.shtml

Yalnizyan, A. (1998). The Growing Gap: A Report on Growing Inequality Between the Rich and Poor in Canada. Toronto: Centre for Social Justice.

--.- (2010). The Rise of Canada's Richest 1\%. Ottawa: Canadian Centre for Policy Alternatives

Yates, C. (1993). From Plant to Politics: The Autoworkers Union in Postwar Canada. Philadelphia: Temple University Press.

Yates, C. and B. Leach. (2007). Industrial Work In a Post-Industrial Age. In Shalla, V. and W. Clement (Eds.), Work In Tumultuous Times (163-191). Montreal and Kingston: McGillQueens University Press. 